\title{
Globalising Democracy
}

Globalising Democracy brings together expert contributors to explore the intersection of two major contemporary themes: globalisation and the contribution that both domestic party politics and international party aid, in particular, make to democratisation.

This new volume clearly shows what globalisation means for domestic and international efforts to build effective political parties and competitive party systems in new and emerging democracies. Contrasting perspectives are presented through fresh case studies of European postcommunist countries, together with Turkey, which at first glance seem to tell a positive story, and of sub-Saharan Africa, where the problems and the challenges are more complex. The reader is clearly shown how international party assistance is one manifestation and vehicle of globalisation, understood in the political sense: as the global convergence of a distinctive set of (Western-derived) political values and institutions takes place.

This book also shows how globalisation assessed in terms of global economic integration, the growth of global communications and the development of multilevel (or polycentric) governance poses serious implications for party politics almost everywhere. Such themes are highly relevant to how new and emerging democracies can find a set of party politics fit for the purpose of improving and consolidating their respective systems.

This book will be of great interest to all students of globalisation, governance, international relations and politics.

Peter Burnell is a Professor in the Department of Politics and International Studies at the University of Warwick, UK. 


\title{
Routledge/Warwick Studies in Globalisation
}

\author{
Edited by Richard Higgott and published in association with \\ the Centre for the Study of Globalisation and Regionalisation, \\ University of Warwick
}

What is globalisation and does it matter? How can we measure it? What are its policy implications? The Centre for the Study of Globalisation and Regionalisation at the University of Warwick is an international site for the study of key questions such as these in the theory and practice of globalisation and regionalisation. Its agenda is avowedly interdisciplinary. The work of the Centre will be showcased in this new series.

This series comprises two strands:

Warwick Studies in Globalisation addresses the needs of students and teachers, and the titles will be published in hardback and paperback. Titles include:

Globalisation and the Asia-Pacific

Contested territories

Edited by Kris Olds, Peter Dicken,

Philip F. Kelly, Lily Kong and Henry

Wai-chung Yeung

Regulating the Global Information Society Edited by Christopher Marsden

Banking on Knowledge

The genesis of the global development network

Edited by Diane Stone

Historical Materialism and Globalisation Edited by Hazel Smith and Mark Rupert

Civil Society and Global Finance

Edited by Jan Aart Scholte with Albrecht Schnabel

Towards a Global Polity

Edited by Morten Ougaard and

Richard Higgott

New Regionalisms in the Global Political

Economy

Theories and cases

Edited by Shaun Breslin, Christopher

W. Hughes, Nicola Phillips and Ben

Rosamond

Globalising Democracy

Political parties in emerging democracies

Edited by Peter Burnell

Routledge/Warwick Studies in Globalisation is a forum for innovative new research intended for a high-level specialist readership, and the titles will be available in hardback only. Titles include:

1. Non-State Actors and Authority in the Global System

Edited by Richard Higgott, Geoffrey Underhill and Andreas Bieler

2. Globalisation and Enlargement of the European Union

Austrian and Swedish social forces in the struggle over membership

Andreas Bieler

\section{Rethinking Empowerment}

Gender and development in a global/local world

Edited by Jane L. Parpart, Shirin M. Rai and Kathleen Staudt

4. Globalising Intellectual Property Rights

The TRIPs agreement

Duncan Matthews

5. Globalisation, Domestic Politics and

Regionalism

The ASEAN free trade area

Helen E. S. Nesadurai

6. Microregionalism and Governance in

East Asia

Katsubiro Sasuga

7. Global Knowledge Networks and International Development

Edited by Diane Stone and Simon Maxwell

8. Globalisation and Economic Security in East Asia

Governance and institutions

Edited by Helen E. S Nesadurai

9. Regional Integration in East Asia and

Europe

Convergence or divergence?

Edited by Bertrand Fort and Douglas Webber

10. The Group of Seven

Finance ministries, central banks and global

financial governance

Andrew Baker

11. Globalisation and Poverty

Channels and policy responses

Edited by Maurizio Bussolo and

Jeffery I Round

12. Democratisation, Governance and

Regionalism in East and Southeast Asia

A comparative study

Edited by Ian Marsh

13. Assessment and Measurement of Regional Integration

Edited by Philippe De Lombaerde

14. The World Bank and Governance

A decade of reform and reaction

Edited by Diane Stone and Christopher Wright

15. Nationalism \& Global Solidarities

Alternative projections to neoliberal

globalization

Edited by James Goodman and Paul James 


\title{
Globalising Democracy Party politics in emerging democracies
}

\author{
Edited by \\ Peter Burnell
}


First published 2006 by Routledge

Published 2017 by Routledge

2 Park Square, Milton Park, Abingdon, Oxon OX14 4RN

711 Third Avenue, New York, NY 10017, USA

Routledge is an imprint of the Taylor \& Francis Group, an informa business

Copyright (c) 2006 Peter Burnell for selection and editorial material; individual chapters, their contributors

Typeset in Sabon by

Florence Production Ltd, Stoodleigh, Devon

The Open Access version of this book, available at www.tandfebooks.com, has been made available under a Creative Commons Attribution-No Commercial-No Derivatives 4.0 license.

British Library Cataloguing in Publication Data A catalogue record for this book is available from the British Library

Library of Congress Cataloging in Publication Data A catalog record for this book has been requested

ISBN13: 978-0-415-40184-5 (hbk)

ISBN13: 978-0-415-40183-8 (pbk) 


\section{Contents}

List of tables

Notes on contributors

vii

Acknowledgements

viii

List of abbreviations

ix

$\mathrm{X}$

1 Globalising party politics in emerging democracies

PETER BURNELL

2 Political parties, international party assistance and globalisation

PETER BURNELL

3 Political parties and the democratisation of globalisation

4 Examining international political party aid

THOMAS CAROTHERS

5 East-Central Europe: parties in crisis and the external and internal Europeanisation of the party systems

ATTILA ÁGH

6 External assistance for political contenders in transition states: cautionary tales from the Balkans

TOM GALLAGHER

7 Globalisation and party transformation: Turkey's Justice and Development Party in perspective

ZIYA ÖNIŞ

8 Globalising party politics in Africa: the influence of party-based democracy networks 
vi Contents

9 Party assistance and the crisis of democracy in southern Africa

ROGER SOUTHALL

10 Hesitant bedfellows: the German Stiftungen and party aid in Africa

GERO ERDMANN

11 Looking to the future: practice and research in party support

PETER BURNELL

References

Index 


\section{Tables}

7.1 Islamists' changing political agenda in Turkey: stylised comparison of Welfare Party, Virtue Party and Freedom and Justice Party

7.2 Major turning points in defining the space for, and boundaries of, political action for Islamist political parties in Turkey

8.1 Political parties represented in parliament in Ghana, 1993-present

8.2 Political parties represented in the Kenyan National Assembly, 1992, 1997 and 2002

8.3 Political parties represented in Malawi's National Assembly, 1994, 1999 and 2004

8.4 Ethnic character and voting behaviour of major political parties in Ghana, Kenya and Malawi

10.1 Regional distribution of German political foundations' spending, 2001-05

10.2 Project activities and offices of German foundations in African countries, 2005

10.3 Bilateral partners of German political foundations in Africa, 2005 


\section{Notes on contributors}

Attila Ágh is Professor at the Department of Political Science, Budapest Corvinus University, Hungary, and Director of the Research Centre 'Together for Europe' at the Hungarian Academy of Sciences.

Peter Burnell is a Professor of Politics at the University of Warwick.

Thomas Carothers is Vice President for International Politics and Governance at the Carnegie Endowment for International Peace, Washington DC.

Gero Erdmann is Senior Research Fellow at the German Institute of Global and Areas Studies, Institute of African Affairs (Hamburg), Berlin Office.

Tom Gallagher is Professor and Chair of Ethnic Conflict and Peace at Bradford University.

Ziya Öniş is a Professor of International Relations in the College of Administrative Sciences and Economics, and Director of the Centre for Research on Globalization and Democratic Governance, at Koç University, Istanbul.

M. A. Mohamed Salih is a Professor of the Politics of Development in the Department of Political Science, University of Leiden, and the Institute of Social Studies, The Hague, the Netherlands.

Jan Aart Scholte is a Professor in the Department of Politics and International Studies at the University of Warwick and Co-director of the Economic and Social Research Council Centre for the Study of Globalisation and Regionalisation at the University of Warwick.

Roger Southall is Distinguished Research Fellow, Human Sciences Research Council (HSRC), Pretoria, South Africa, and formerly Executive Director of the Democracy and Governance Research Programme at HSRC. 


\section{Acknowledgements}

This volume had its origins in a workshop on 'Globalising Party-based Democracy' held at the University of Warwick in July 2005. The support of the ESRC-funded Centre for the Study of Globalisation and Regionalisation for this event is gratefully acknowledged. Of the twenty-seven participants in the workshop two-thirds came from academic institutions and one-third from policy research institutes and practitioner organisations in democracy support. In total ten different countries were represented, including new as well as old democracies. The editor thanks all the participants for the lively discussions and helpful comments on the presentations in this unique event.

In respect of Chapter 3, Jan Aart Scholte wishes to thank Peter Burnell for helpful feedback on an earlier draft. With regard to Chapter 7, Ziya Öniş thanks Koray Mutlu for his able assistance. With regard to Chapter 10, Gero Erdmann thanks the Heads of the International or Africa Departments of the Heinrich Böll, Friedrich Ebert, Konrad Adenauer and Friedrich Naumann Stiftung for generous interview time. In addition he thanks the German Research Foundation (DFG), which financed his research project 'Political Parties and Party Systems in Anglophone Africa: Botswana, Ghana, Malawi, Tanzania and Zambia' that provided the background for a better understanding of the particular challenges of party aid in Africa, surveyed in Chapter 10. 


\section{Abbreviations}

$\begin{array}{ll}\text { AAK } & \text { Association for the Future of Kosovo } \\ \text { AFORD } & \text { Alliance for Democracy (Malawi) } \\ \text { AKP } & \text { Justice and Development Party (Turkey) } \\ \text { ANAP } & \text { Motherland Party (Turkey) } \\ \text { ANC } & \text { African National Congress (South Africa) } \\ \text { ASEAN+3 } & \begin{array}{l}\text { Association of Southeast Asian Nations plus China, Japan } \\ \text { and South Korea }\end{array} \\ \text { ASEM } & \text { Asia-Europe Meetings } \\ \text { BDP } & \text { Botswana Democratic Party } \\ \text { BMZ } & \text { Ministry of Economic Co-operation and Development } \\ & \text { (Germany) } \\ \text { CCM } & \text { Chama Cha Mapinduzi (Tanzania) } \\ \text { CCP } & \text { Coalition for a Clean Parliament (Romania) } \\ \text { CD } & \text { Community of Democracies } \\ \text { CDU } & \text { Christian Democratic Union (Germany) } \\ \text { CEEB } & \text { Central and Eastern Eurobarometer } \\ \text { CHP } & \text { Republican People's Party (Turkey) } \\ \text { CPA } & \text { Commonwealth Parliamentary Association } \\ \text { CSGR } & \text { Centre for the Study of Globalisation and Regionalisation } \\ & \text { (UK) } \\ \text { CSU } & \text { Christian Social Union (Germany) } \\ \text { CUF } & \text { Civic United Front (Tanzania) } \\ \text { DFID } & \text { Department for International Development (UK government) } \\ \text { DOS } & \text { Democratic Opposition of Serbia } \\ \text { DP } & \text { Democratic Party (Kenya) } \\ \text { DPA } & \text { Dayton Peace Agreement (1995) } \\ \text { DRC } & \text { Democratic Republic of the Congo } \\ \text { DSP } & \text { Democratic Left Party (Turkey) } \\ \text { DYP } & \text { True Path Party (Turkey) } \\ \text { EC } & \text { European Community } \\ \text { ECE } & \text { East-Central Europe } \\ \text { EFA } & \text { European Free Alliance } \\ \text { EGLE } & \text { Every Ghanaian Living Everywhere Party } \\ & \\ & \end{array}$




\begin{tabular}{ll} 
EP & European Parliament \\
EPP & European People's Party \\
EU & European Union \\
FCO & Foreign and Commonwealth Office (UK government) \\
FDI & foreign direct investment \\
FDP & Free Democratic Party (Germany) \\
FES & Friedrich Ebert Stiftung (Germany) \\
FIDESZ & Hungarian Civic Union \\
FNS & Friedrich Naumann Stiftung (Germany) \\
FORD & Forum for the Restoration of Democracy (Kenya) \\
FP & Virtue Party (Turkey) \\
FRELIMO & Mozambique Liberation Front \\
FSC & Forestry Stewardship Council \\
G8 & Group of Eight \\
GDP & gross domestic product \\
GDR & German Democratic Republic \\
GLOBE & Global Legislators Organisation for a Balanced Environment \\
HBS & Heinrich Böll Stiftung (Germany) \\
HSS & Hans Seidel Stiftung (Germany) \\
IASB & International Accounting Standards Board \\
ICANN & Internet Corporation for Assigned Names and Numbers \\
IDEA & International Institute for Democracy and Electoral \\
& Assistance \\
IDU & International Democrat Union \\
IEC & Independent Electoral Commission (South Africa) \\
IMD & Institute for Multiparty Democracy (Netherlands) \\
IMF & International Monetary Fund \\
INGO & international non-governmental organisation \\
IPU & Inter-Parliamentary Union \\
IRI & International Republican Institute (United States) \\
KANU & Kenya African National Union \\
KAS & Konrad Adenauer Stiftung (Germany) \\
LGBT & Lesbian, Gay, Bisexual, Transgender \\
LI & Liberal International \\
MCP & Malawi Congress Party \\
MDC & Movement for Democratic Change (Zimbabwe) \\
MERCOSUR Southern Common Market (in Latin America) \\
MEP & Member of the European Parliament \\
MHP & Nationalist Action Party (Turkey) \\
MP & Member of Parliament \\
MÜSÏAD & Independent Industrialist and Businessmen's Association \\
& (Turkey) \\
NARC & National Rainbow Coalition (Kenya) \\
NATO & North Atlantic Treaty Organisation \\
NDC & National Democratic Congress (Ghana) \\
& \\
\hline
\end{tabular}




$\begin{array}{ll}\text { NDI } & \text { National Democratic Institute (United States) } \\ \text { NED } & \text { National Endowment for Democracy (United States) } \\ \text { NGO } & \text { non-governmental organisation } \\ \text { NPM } & \text { New Policy Management } \\ \text { NPP } & \text { New Patriotic Party (Ghana) } \\ \text { OECD } & \text { Organisation for Economic Co-operation and Development } \\ \text { OSCE } & \text { Organisation for Security and Co-operation in Europe } \\ \text { OSF } & \text { Open Society Foundation } \\ \text { PAP } & \text { Pan-African Parliament } \\ \text { PD } & \text { Democratic Party (Romania) } \\ \text { PDK } & \text { Kosovo Democratic Party } \\ \text { PDS } & \text { Party of Democratic Socialism (Germany) } \\ \text { PES } & \text { Party of European Socialists } \\ \text { PGA } & \text { Parliamentarians for Global Action } \\ \text { PKK } & \text { Kurdish Workers' Party (Turkey) } \\ \text { PNDC } & \text { Provisional National Defence Council (Ghana) } \\ \text { PNoWB } & \text { Parliamentary Network on the World Bank } \\ \text { PRSP } & \text { Poverty Reduction Strategy Paper } \\ \text { PS } & \text { Parti Socialiste (Senegal) } \\ \text { PSD } & \text { Social Democratic Party (Romania) } \\ \text { RENAMO } & \text { National Resistance of Mozambique } \\ \text { RLS } & \text { Rosa Luxemburg Stiftung (Germany) } \\ \text { RP } & \text { Welfare Party (Turkey) } \\ \text { RS } & \text { Republic of Srpska } \\ \text { SACP } & \text { South African Communist Party } \\ \text { SADC } & \text { Southern African Development Community } \\ \text { SAR } & \text { Romanian Academic Society } \\ \text { SEED } & \text { Support for East European Democracy Act (US) } \\ \text { SI } & \text { Socialist International } \\ \text { SPD } & \text { Social Democratic Party (Germany) } \\ \text { SWAPO } & \text { South West African People's Organisation (Namibia) } \\ \text { UCLG } & \text { United Cities and Local Governments } \\ \text { UDF } & \text { United Democratic Front (Malawi) } \\ \text { UN } & \text { United Nations } \\ \text { UNDP } & \text { United Nations Development Programme } \\ \text { UPADD } & \text { Union des Partis Africains pour la Démocratie et le } \\ & \text { Développement (Niger) } \\ \text { USAID } & \text { United States Agency for International Development } \\ \text { WFD } & \text { Westminster Foundation for Democracy (United Kingdom) } \\ \text { WTO } & \text { World Trade Organization } \\ \text { ZANU-PF } & \text { Zimbabwe African National Union-Patriotic Front } \\ \text { ZEC } & \text { Zanzibar Electoral Commission } \\ & \end{array}$




\title{
1 Globalising party politics in emerging democracies
}

\author{
Peter Burnell
}

The aims of this book are threefold. The first is to draw greater attention to the idea that globalisation matters to the way party politics develops in new and emerging democracies. The second, and more emphatic, is to critically review international political party aid as both a vehicle and manifestation of the globalisation of party-based democracy, which itself is an aspect of globalisation understood in its broadest and most political sense - meaning the global convergence of a distinctive set of (Westernderived) political values and institutions. The third aim is to make the case that if international party aid is to become a more effective instrument for promoting democratisation in new and prospective democracies, then it should take account of the ways globalisation touches on democratisation and the development of party politics specifically. If the book helps to confirm that both the connections between political parties and globalisation and their consequences for democratisation, and the performance of international party aid, merit further and more detailed investigation, then it will have achieved a worthwhile objective.

For the purposes of this book, then, the term 'globalisation of party politics' has the following reference points. The first is the spread of political party-based forms of political activity and (in varying degrees of competitiveness) party politics as a form of political organisation, connected with the increasing adoption by states of more or less democratic forms of government. The second is the efforts of foreign, international and supranational organisations to promote party-building and consolidate liberal democratic norms and practices among competing parties in emerging democracies. This feature is given special prominence, not least because it has been so little researched and commented on elsewhere. Third, the term refers to how the development of party-based democracy is affected by certain aspects of globalisation such as national economic integration into one global economic space through the standardisation on neo-liberal economic policies and institutions at national and transnational levels. For there is a view that globalisation in the sense of economic integration, along with the growth of global communications and the development of multi-level (or polycentric) governance, poses 


\section{Peter Burnell}

serious implications for political parties almost everywhere. And it has particular resonance for those countries currently addressing the challenge of institutionalising a system of party politics fit for the purpose of improving and consolidating a new democracy. Finally, the terms of reference here embrace the impact of regionalisation, more specifically Europeanisation, on the development of political parties and party politics in post-communist countries, in as much as regionalisation still exhibits some of globalisation's central characteristics even where it is conceived as an instrument to protect member states' interests against the more threatening consequences of globalisation manifest at the global level.

\section{Introduction}

In Western Europe there is now a widely held view that the golden age of mass party politics is over. This is part of a larger contemporary scenario that has seen patterns of political participation move in the direction of declining party membership and electoral turnouts, reductions in partisan attachment and increasing voter volatility. Some historians now even question whether the golden age ever existed in the first place. One inference echoed in the literature is that it would be unrealistic to expect today's new and emerging democracies - even in parts of Central and Eastern Europe where new democratic forms are now already well stabilised - to reproduce in full the models and trajectories of party politics hitherto associated with what may look like a mythical past in Western Europe - and that it would be doubly unrealistic for any new democracies that lack such predisposing conditions as substantial industrialisation, urbanisation and high literacy levels that fuelled mass participatory politics in the West, or for societies such as those in Africa where 'traditional' neo-patrimonial and clientelist cultures still exert a strong influence contrary to the 'modernising' trends associated with globalisation in other parts of the world. ${ }^{1}$ Thus although in one sense we might expect party politics to develop somewhat differently in today's new democracies simply by virtue of being able to take advantage of lessons the politicians acquire from the history of party development in longer established democracies, there may well be limits to what can be understood - and to any predictions that might be ventured - in this way.

This insight is far from new. However, there is a yet further but less often remarked upon complication, owing to the fact that a great deal of our understanding of party politics begins and ends at the level of the nation and state. But the context that contemporary globalisation now provides to the development of parties and party systems everywhere and in new democracies in particular differs profoundly from the external environment that faced political parties in the formative days of today's long-established democracies, and that was much less important to them. It suggests another powerful reason why we cannot identify all the 
influences upon party politics in today's new democracies simply by studying patterns from the past. And for those international actors who make it their business to support the development of parties and party systems in today's newly emerging and prospective democracies so that party politics is 'fit for purpose' of consolidating and improving democracy in the years ahead, then it could have significant implications for how they structure their activities and what they can hope to achieve. Thus the study of party politics in new democracies must be alert to the role of international factors including international party support. And any critical assessment of international party support must take account of globalisation rather than view party politics or party support in isolation.

Globalisation is, of course, a much contested concept, but invariably portrayed as multifaceted or multi-dimensional. The degree of novelty in the current era and its full extent and significance are all subjects of enormous debate. At its simplest globalisation refers to the widening, deepening and speeding up of worldwide interconnectedness. More than that, McGrew (2005: 23) says that in the political sphere globalisation comprises: the stretching of politics across frontiers - the interests of a community can be significantly affected by decisions taken by others at a remote distance; a thickening of the infrastructures of worldwide political interaction, especially those engaged in rule-making; acceleration of political processes in part due to expansion of global communications; and a blurring of the local-global, or domestic-foreign, divide. A marked feature of globalisation in its political aspect refers to the way a distinctive set of political ideas, norms and institutions revolving around familiar Western conceptions of democracy are together becoming increasingly more common throughout the world, even if the reasons for this convergence, its normative implications and future sustainability are all in dispute. In fact democratisation as a phenomenon that has occurred increasingly across different countries, regions and cultures in part due to international and supraterritorial influences is a feature of contemporary globalisation that is quite distinctive from all of contemporary globalisation's previous stages, forerunners or antecedents. And yet this is happening at the very historical juncture when certain other leading features or primary manifestations of globalisation - global economic integration (furthered through a delinking of markets from states and the application of standard neo-liberal economic solutions); the emergence of multiple locations of (sometimes called multi-level) governance; and the growth of a global communications network - are all thought by some to severely challenge the worth of democracy in its established heartland, the sovereign nation(al) state. Even the less expansive notions of globalisation such as those that identify it more narrowly with increase in supra- and transterritoriality do not differ fundamentally: they too herald a combination of some positive and some negative connotations for democracy and its spread. On the one hand democratically elected governments may witness 


\section{Peter Burnell}

an erosion of their powers and authority, and yet on the other hand, various sub-state, non-state and multinational actors come to co-operate across borders for purposes that expressly include the promotion of fundamental human rights central to democracy and other democratic goals and objectives.

\section{The political parties dimension}

The literature on contemporary democratisation is no less voluminous and rich in internal debates than is the literature on globalisation, but certain core assumptions can be found in most accounts. In a world where it seems democracy has to mean representative government, one of the most commonly assumed - and frequently restated - propositions is that political parties are central to democracy. For example Diamond and Gunther (2001: xviii) say that in the effort to consolidate new or recent democracies, "parties remain dominant in structuring the electoral process, governing, and perhaps even in "symbolic integration" of citizens into the democratic process'. Yet at the same time in the newer democracies there are clearly 'problems of performance and legitimacy' with the parties (Diamond and Gunther, 2001: xxxi). Strong parties and effective party systems are essential to good democracy, not least so as to furnish government that is capable of managing and responding to the forces of globalisation in ways that serve the needs of the people and their entitlement to self-rule. And plural politics are important to ensuring that whichever party or parties make up the government they will be rendered accountable by other parties for their exercise of the power that comes with public office.

Indeed the global spread of party-based democracy is no mere accident. Increasingly, observers are coming to recognise the considerable influence on democratisation of a range of international factors in addition to the direct effects of the end of the cold war and the collapse of the Soviet Union. External imposition appears to be one route to bringing about democracy, although its effectiveness is probably confined to very few cases. Diplomatic pressure and the attachment of democratic and human rights conditionalities to offers of financial support or development aid and to the qualifications needed for membership of valued and prestigious regional trade and other groupings or clubs offer further well-developed strategies. And yet another approach that is often practised in combination with the other measures is the provision of practical forms of democracy assistance. The number and variety of organisations - governmental, intergovernmental, and non-governmental - involved in such activities grew dramatically in the 1990s to include special institutes and foundations in some of the newer democracies as well as the older democracies, all oriented towards what has become a very cosmopolitan enterprise, the 
promotion and protection of democracy abroad. Not all of them have 'gone global', for some choose to concentrate their limited resources on but a few countries. And yet some do increasingly recruit their personnel - advisers and 'democracy trainers' - from a global labour market; and seek to match the kind of people they put in the field with the societies where they become operational. There is some measure of transatlantic co-operation and a somewhat larger amount of transnational discussion among the various democracy assistance organisations. In the established democracies public support for democracy promotion appears to be strong; the likelihood is that democracy assistance is here to stay, for the foreseeable future anyway. ${ }^{2}$

Within this increasingly multinational community of policy organisations, practitioner bodies, think-tanks, commercial consultancies and the like all having an interest in the provision of democracy assistance, there is growing recognition that just as we conceive democracy to be party based, so support to the development of appropriate parties and party systems must become a more important feature of democracy promotion in emerging and prospective new democracies. ${ }^{3}$ One compelling reason is that the bias that international development co-operation has shown in recent decades towards promoting economic markets ('Washington consensus' and other neo-liberal solutions) and to furthering 'good governance' (even if not 'bringing the state back in'), fails to address the condition of political society, where parties are a major component. This has enormous significance both for the functioning of markets and for governance - the two of course being intimately connected - through such variables as the quality of political leadership and the attitude politicians take to the exercise of political power. These can range from essentially shorttermist and particularistic inclinations to more worthy ideas of ruling for the long-term public good. The ability of party politics to channel underlying social and economic conflict in peaceful ways is another critical element to both markets and governance, especially in societies that have a violent past. If party politics can be said to provide a public service for democracy and democratisation, ${ }^{4}$ then the risks attendant on an inappropriate expression or under-provision or some other sign of market failure may be nowhere more threatening than in new democracies, which have yet to acquire the stability and depth associated with the longer established democracies. The longer established democracies' own problems with what many political analysts now perceive to be a decline in party politics may be far less damaging. Needless to add, the development and maintenance of well-institutionalised parties and party systems should improve a society's chances of extracting the potential benefits globalisation offers to democracy and democratisation. Conversely, weak parties that are subservient to highly personalist forms of leadership, or party systems where one party exercises political hegemony or, on the 


\section{Peter Burnell}

contrary, the proliferation of parties and factionalisation are rife, could all render democracy and democratisation more vulnerable to the potential harm that increasing exposure to globalisation may bring.

\section{Democracy assistance institutions}

The institutionalisation of organisations at the regional and global levels in addition to more localised and national initiatives for the promotion and protection of democracy around the world is a distinctive feature of the current age. An example is the Community of Democracies (CD), a loose agreement among more than 100 countries that met for the first time in 2000 in Warsaw, and that some observers see as a basis for elevating the idea that the people are sovereign over more traditional ideas that privilege the sovereignty of the state. $\mathrm{CD}$ actors are invited to rush collectively to defend a society's choice to be a democracy against threatened erosion, coups or autocoups, in any of the member states (see Halperin and Galic, 2005).

Taking party politics as a central feature of democracy and democratisation, organisations as different as the United Nations Development Programme (UNDP) and the Office for Democratic Institutions and Human Rights of the Organisation for Security and Co-operation in Europe (OSCE) are now joining the chorus led by more specialised democracy assistance providers in seizing the importance of extending support to party political development. They include organisations that have a lengthy history of involvement in the issues of party support, most notably Germany's political foundations, or Stiftungen (examined in detail in Chapter 10). Prominent examples in the United States are the National Endowment for Democracy (NED) created in 1983 and two of its main grantees - the National Democratic Institute (NDI) and International Republican Institute (IRI) - as well as the government's own official Agency for International Development (USAID). The last offers to provide support to (in principle all significant) democratic parties in a country, subject only to some exceptional waivers. Very recently the NDI, which claims to have worked with parties in more than 50 countries including nine in Central and Eastern Europe and 15 in black Africa, has taken a particular interest in the regulatory mechanisms that directly impact on parties (party law; party finance), internal party governance and communications outreach. In this book (Chapter 4) Carothers critically examines party aid, especially but not only from the US, bringing out findings from his detailed observations in the field and also the assessments made by actors directly involved in party aid.

Britain has the Westminster Foundation for Democracy (WFD) and Australia the Centre for Democratic Institutions, established in 1998 with core funding from the government's Agency for International Development, 
which has a particular interest in the distinctive party politics as well as the parliamentary governance of small Pacific island states, and a focus on Indonesia, too. The Institute for Multiparty Democracy (IMD), which is based on inter-party co-operation in the Netherlands, is even more tightly focused on party support and on developing systems of party politics characterised by trust in the democratic process. For the IMD, that means a special commitment to cross-party projects and being impartial among parties, contrasting with the bilateral party work that some other actors are engaged in. Clearly a number of the organisations are part of the machinery of government, USAID for instance; others enjoy an 'arm's length' relationship even though much or all of their funding ultimately comes from the public purse, as in the case of the NED and WFD. The International Institute for Democracy and Electoral Assistance (IDEA), based in Stockholm, is rather different, as it is an inter-governmental body of 23 members drawn from both the developed and developing worlds that seeks to promote knowledge and understanding, instead of being a supplier of more concrete forms of assistance. It has a substantial research programme on the role of parties, including the way political party funding is regulated around the world. ${ }^{5}$

In addition to government departments, independent foundations, thinktanks and policy advice bodies such as the Carnegie Endowment for International Peace in Washington DC, there is the web of relations among political parties in new and older democracies or with affiliates of parties such as Germany's Stiftungen and the Olof Palme International Center in Sweden. Some parties in newer democracies in turn are setting up similar outreach activities albeit on a much smaller scale - for example parties represented in Hungary's parliament made the decision to establish state-sponsored foundations modelled after Germany's Stiftungen. Various forms of support and collaboration take place, including in some cases the distribution of public money. Parties collectively network among themselves also in formally constituted party internationals (Chapter 8 surveys African examples). Finally a handful of academics in several countries and a number of commercial consultancies especially in the US complement the informal membership of this rather distinctive 'transnational knowledge elite'.

The closer attention that is now beginning to be called for in respect of the political party component of democratisation and of democracy support was not always thus - and in terms of the resources allocated it starts from a very low base. Precise figures are difficult to calculate because of definitional and recording difficulties, but they lie in the millions rather than the billions of euros, pounds or dollars. Van Wersch and de Zeeuw (2005) calculate the combined budgets in 2004 of the main European democracy foundations - the great majority of them formed within the last 20 years - at around 400 million euros, of which perhaps around 


\section{Peter Burnell}

70 per cent is allocated to expenditures broadly related to political parties, including training, organisation of conferences and workshops, advice and technical assistance. Although Germany's political foundations account for the lion's share of all expenditure, their proportion devoted to party work appears to substantially less (see Chapter 10). In the US the International Republican Institute and the National Democratic Institute had a combined overall budget equivalent to around 75 million euros in the same year. ${ }^{6}$

In part the growing interest in party politics has come about as a consequence of realising that elections alone do not make a democracy and that the attractive proposition that involvement with a country's civic associations offers a politically safe, diplomatically non-embarrassing way of boosting democratisation is also flawed. First, although there are notable examples where action by civil society and protest movements have seriously weakened or brought down an authoritarian regime, their potential to meet the political requirements of democratic construction and consolidation should not be exaggerated, especially where, as sometimes happens, the energy civil society displays during a 'democratic revolution' subsequently dwindles or allows democratic reversal to take place. Second, a belief that engagement with civil society enables external actors to maintain a safe distance from involvement in domestic political conflict has turned out to be misplaced. Moreover the likelihood that support to nongovernmental organisations (NGOs) can make a significant contribution to meaningful political change has come to be questioned in many cases, by observers noting typical NGO weaknesses such as acute dependence on foreign funding. So, while the early years of international democracy support gave considerable attention to elections observation and monitoring (complemented recently by a firmer appreciation of the need to consolidate competent, non-partisan management of the electoral process) and invested quite heavily in civil society capacity-building, the limitations of these endeavours are now widely understood. For these reasons the globalisation of party politics as an objective and programme of action is now more firmly in the sights and thinking of democracy aid organisations than perhaps at any previous time. However, what the democracy aid industry has not yet brought fully into focus is how the goal of promoting party-based democracy is affected by the forces of globalisation understood in either a narrow or larger sense.

\section{Globalisation and party politics}

Researching the globalisation of party politics in new and emerging democracies must draw on the insights of several literatures, some of them very substantial, such as those on globalisation, democratisation and comparative political parties, along with a much smaller literature that has appeared only in the last decade or so, namely on democracy promotion. There is a barely visible sub-literature on party assistance specifically. 
As recently as 2005 Kumar concluded an overview of international political party assistance with the claim (only a slight overstatement) that the 'academic literature on the subject is almost non-existent; there are no scholarly articles, graduate theses, or books .... W Writing as a practitioner, he argued, 'This information gap urgently needs to be bridged in order to promote sensible policies and effective programming' (Kumar, 2005: 526). ${ }^{7}$ Even on party-based democratisation the relevant literatures do not talk to one another very often. Very little of the enormous body of scholarship devoted to making sense of globalisation dwells primarily on issues of party politics anywhere, which contrasts with the large amounts of material on civil society and social movements. ${ }^{8}$ And even a substantial part of the extensive literature on party politics in the developed world does not overtly and directly touch on the impact of globalisation, although there are notable exceptions, where connections are often drawn implicitly as much as explicitly (such as Schmitter, 2001; Katz and Mair, 2002; Blyth and Katz, 2005; Poguntke and Webb, 2005). It offers even less on how party politics (construed as independent variable) has consequences for globalisation (as dependent variable). This is something that the confines of this book can do little to redress even while it states the case for international party aid to do more to equip parties in emerging democracies to relate to globalisation as autonomous actors. As Scholte (Chapter 3) observes quite correctly, the effective democratisation of globalisation probably requires concurrent initiatives from multiple complementary agendas: changes in the organisation and activities of political parties could potentially make a worthwhile difference, but would by no means be sufficient. However, it is true to say that US party support specifically and a one-dimensional conception of globalisation that emphasises economic liberalism have been brought together by Robinson (1996). But his neo-Gramscian perspective, which leads him to interpret democracy promotion as a means to further the hegemony of US transnational capital, reflects neither the declared goals of party aid practitioners nor the tone of much academic research in Europe, where transnational party co-operation has been studied by Pridham in some detail. ${ }^{9}$

What does globalisation mean for the complex challenge of building viable and effective political parties and stable, competitive and effective party systems in emerging and prospective new democracies? How does globalisation affect the ability of new parties and party systems to make a constructive contribution to democratisation? Given the paucity of published evidence about the actual practice of international party support, what can be ascertained about the performance of this distinctive feature of democracy assistance and its effectiveness in furthering democratisation, in countries where non-democratic forms of rule have prevailed until recently? What do advocates of such support need to know about globalisation and its implications for party politics, if they are to have an adequate grasp of the challenge, entertain feasible goals and design 


\section{Peter Burnell}

appropriate methodologies for judging the results? These are the kinds of questions that have not been posed often enough. The chapters in this book offer a variety of responses; inevitably there is only a small selection of all the possible cases.

\section{The cases}

Globalisation's reach varies greatly from one society to another, and within individual countries too its impact tends to be uneven. As a historical process of change globalisation continues - will continue - to unfold; most countries are on a moving train. The suggestion sometimes made that certain countries, whole regions even or particular sections of society (an 'underclass', for instance) are largely untouched by globalisation and will remain in that condition indefinitely - may be rephrased differently: it is correct that they have yet to share in the economic benefits of globalisation, defined in largely economic terms. Yet it is quite conceivable they are among the casualties of globalisation; they incur certain disadvantages as a result of the way other countries and communities are being integrated into the global economy more rapidly. At the same time there are people in every country who are 'winners' from globalisation, and many more who derive no great economic benefit or loss but nevertheless are touched by aspects of globalisation that the most restrictively economistic conceptions of that phenomenon unreasonably neglect.

The cases in this book are drawn from East-Central Europe, south-east Europe, Turkey and sub-Saharan Africa. A larger book would include other regions, among which Latin America poses as a very strong candidate because of its relatively lengthy history of involvement with party politics and the larger political effects of recently coming to terms with closer integration into world economic markets. ${ }^{10}$ The cases here, however, merit consideration on a number of criteria: as new or emerging democracies (although that does not necessarily mean full Western-style liberal democracy); as countries where party politics is in flux; as countries where international democracy assistance has paid attention to political parties or, alternatively the evolving party scene is being influenced either by globalisation directly or globalising trends expressed through regionalisation and other means.

First, post-communist Europe and black Africa are two regions where transitions (back) to some kind of democracy began at the end of the 1980s, later than in the first rounds of democracy's 'third wave' in southern Europe and South America. By 2005 South Africa, Namibia and Ghana for instance were reckoned to be 'free' countries by Freedom House in its annual survey, as were Hungary, Poland, the Czech Republic and Slovakia (all bar Namibia were given the highest possible score - 1 - for political rights). Serbia and Montenegro, and Romania too, qualified as free, whereas the ratings given for Turkey and Bosnia-Herzegovina - like 
those for Kenya, Malawi and a number of other African countries - lay just outside, in the 'partly free' category. Although these judgments refer to the state of political rights and civil liberties and the methodology used to arrive at them is criticised by some analysts, Freedom House ratings nevertheless are widely cited in the democratisation literature as guides to democratic performance. ${ }^{11}$ Mohamed Salih in Chapter 8 maintains that globally informed quasi-polyarchical democracy has now become the norm in much of Africa, notwithstanding a few exceptions such as Zimbabwe (see Chapter 9) that have travelled in the opposite direction and are now judged to be 'not free'. As a leader in the continent South Africa receives close scrutiny in Chapter 9.

Both sub-Saharan Africa and post-communist Europe have been the focus of considerable interest among actors keen to assist democratic progress: for instance Eastern Europe and Euro-Asia plus sub-Saharan Africa account for close to a half of all project expenditures by Europe's political foundations (van Wersch and de Zeeuw, 2005). Central and Eastern Europe since 1989 has been the site of the greatest concentration of international party support - in the 1990s probably receiving as much as half of all party support, with a particular concentration from US sources. The region also enjoys the reputation of being a great success story for democracy promotion by the West and in particular the efforts of the European Union (EU), as reported in for instance Vachudova's (2005: 179) account of 'active leverage' by the EU that 'empowered opposition political parties', providing a focal point for co-operation, transmitting liberal democratic norms and values and promising tangible benefits from EU membership. The interplay between the EU and liberal pro-reform parties in candidates for EU accession was a major force for political system change. But Africa too has witnessed a past history of significant contact with foreign actors in areas of both civil society and political society, including the Stiftungen whose involvement there goes back far enough for them to have come to the view that co-operation with African political parties can be a 'risky business' (see Chapter 10). In short, Africa seems to offer a good contrast to East-Central Europe, in particular because of the belief that in terms of building Western-style parties and party politics it offers more difficult terrain: stereotypical European or Western models do not apply in Africa. And so by the same token there is still much work to be done by the international partners in democracy support.

The colonial impact in the nineteenth century and first half of the twentieth century could be said to have introduced Africa to aspects of globalisation and impacted on their society, politics and culture long before the word gained its current popularity. Since then African countries have acquired extensive experience of dealing with such institutions of global governance as the Bretton Woods organisations (International Monetary Fund (IMF); World Bank), due in many cases to their precarious financial 


\section{Peter Burnell}

situation. Most of them are very familiar with the implications for political self-determination. Over the last decade or so, the countries of EastCentral Europe (and in the Balkans) as well as the majority of African states have a shared experience of making rapid adjustments towards a smaller direct role for the state in economic affairs, by privatising state owned enterprises and by trade liberalisation, for example, and steps to increase inter-regional trade have also been common. However, in terms of both present levels and current trends of global economic integration there is a clear contrast between the two regions: the majority of European countries are well ahead. Africa accounts for only tiny shares of world trade and corporate investment flows, in absolute terms and on a per capita basis. But aside from most African states' close links with multilateral aid organisations, some countries such as South Africa have made dramatic strides in recent years to enter more fully the mainstream of global finance, commerce and trade even if for others this still remains just an unfulfilled aspiration. Yet neither Africa nor the post-communist states have been among the greatest winners of globalisation defined in term of economic growth or increase in average real per capita incomes; this accolade must go to countries such as China and India in recent years and to East Asia's 'tigers' or 'dragons' such as South Korea, Taiwan and Singapore in an earlier period.

Where many of the European countries can claim to be most distinctive is in respect of the Europeanising effects of their membership - both actual and prospective - of the EU. This point applies in some measure to Turkey too, which - in part due to its long cherished ambition to join the EU and to some very positive developments lately in the long-drawn out accession process - has witnessed significant recent developments in its party politics (explored by Öniş in Chapter 7). Turkey is quite highly placed in the political ranking of globalisation - higher than Hungary, for instance ${ }^{12}$ - and as its relations with the EU intensify, Turkey's engagement with features of globalisation more generally, it is likely to increase, too. There are many arguments about the exact relationship of regionalisation (increasing interconnectedness among a contiguous group of states) and Europeanisation (as one specific example) to globalisation. For instance are these processes complementary or contradictory? Does regionalisation express in miniature - on and within the regional level - facets of the more wide-ranging phenomenon that is globalisation? Is regionalism just a precursor or a stepping stone to broader integration into the worldwide processes of globalisation, or can it serve as a permanent vehicle for resisting global pressures? Here is not the place to offer a résumé of such large and complex debates. Suffice to say EU membership may act as a filter of globalisation while at the same time applying to its members and candidates for membership - some of the pressures and opportunities that globalisation itself may bring to bear. At the same time it adds some very distinctive features of its own. This applies especially in the 
field of party politics. ${ }^{13}$ In fact Ágh (in Chapter 5) argues strongly for countries in East-Central Europe for which, notwithstanding their apparently successful transition to democracy, Europeanisation since EU accession has entailed some serious drawbacks for party politics. The features, if not their origins, in part resemble the effects that might be more directly attributable to globalisation in other parts of the world. Turkey's story, at an earlier place in the cycle of EU engagement, appears in a more positive light even though, unlike parties in East-Central Europe, there has been no specific democracy aid to the parties. Whether the EastCentral European examples hold up a mirror to Turkey's future or whether, instead, Turkey offers a model that might travel to other societies in the Islamic world where international democracy assistance organisations are now starting to take more serious interest are certainly intriguing issues. Like the question of whether Political Islam constitutes a globalising force of its own that is in serious competition with Western-based notions and manifestations of globalisation, they must lie beyond the confines of this book.

For sure, a more broadly based comparative study of countries than can be accommodated in this collection will be needed in order to take further forward our understanding of the full significance of globalisation for party politics. And that means a more extended collaboration among different area specialists. But studies in this collection have special relevance to that very specific and rather distinctive feature whereby the party politics component of party-based democracy is coming to be more widespread, notably in newer and emerging democracies through the ways and means of international party support.

\section{Notes}

1 On these grounds Van Cranenburgh (1999: 104) goes so far as to question the point of extending international support to parties in African countries, because of their personalistic and clientelistic nature: 'The idea that direct support to African political parties as they function at present is an instrument to further democracy assumes, mistakenly, that they are actually "agents of democracy" or can be made to function as such.' For a critical assessment of African parties' performance of basic functions for democracy and democratic consolidation, see also Randall and Svåsand (2002b).

2 The German Marshall Fund of the United States (2005) reported that 74 per cent of European respondents and 51 per cent of Americans expressed support for democracy promotion, and that although US Democrats were much less supportive than Republicans - probably because they associated the idea with the Bush administration - a majority even of Democrats supported the use of 'soft power' to promote democracy, such as monitoring elections and support to independent groups.

3 One example is the conference on 'Achieving sustainable political change in emerging democracies: the political party challenge', organised in London, March 2004, under the auspices of the UK's Westminster Foundation for Democracy. It was attended by over 50 participants from many countries, 


\section{Peter Burnell}

including senior representatives from several major democracy foundations and development organisations. Burnell (2004) contains a report of the discussions.

4 Van Biezen (2004) describes parties as 'public utilities'.

5 All these organisation have websites that detail their activities. A general introduction to their world is Burnell (2000), which inter alia contains Mair 2000a on Germany's political foundations. Scott and Walters (2000) offers more detail on the NED in particular.

6 Germany's foundations are documented more fully in Chapter 10. The IMD, founded in 2000 and funded by the Dutch Ministry of Foreign Affairs, spent 6.6 million euros on its 14 country programmes in 2005 (over half of them in Africa) and now looks set to consolidate its position. In Britain around half the WFD's spending on political party projects overseas from its total annual budget of around $£ 4$ million from the government's Foreign and Commonwealth Office (FCO) takes place through Britain's political parties. A portion of the rest goes on cross-party projects, which the WFD would like to expand. In recent years up to 87 per cent of project spend has been in Europe and Africa. Average project cost is under $£ 10,000$. A generally critical report by River Path Associates (2005) commended the WFD's investment in international networks of political parties, and the value of the WFD's ability to work with certain partners and environments where diplomatic sensitivities preclude direct FCO involvement was underscored in the government's response to the report. In the US, it was not until 2003 that the NED's core appropriation for all spending exceeded US\$40 million for the first time (plus a further US\$10 million of 'special funding'). The NED's grant allocations to political parties have historically accounted for only around 15 per cent of the total expenditure on overseas partners abroad, or little over half the proportion allocated to civic organisations.

7 Exceptions to Kumar's generalisation include Carothers (1999: 140-55; 2004b), Burnell (2001) and Kumar (2005) - the most widely available study to date, although based exclusively on US experience. However, Carothers (2006) will be a major new addition to the literature and should be read alongside this book.

8 Exceptions include Garrett (1998), which argues from evidence in the advanced industrial countries between 1966 and 1990 that globalisation does not harm the possibilities of 'social democratic corporatism', and Clift (2002). Garrett's reasoning that the economic gains of globalisation can be reaped without reducing the ability of citizens to choose how to distribute the benefits and costs of the market runs counter to the assumption frequently found in the political economy literature that globalisation understood as increasing trade and financial openness shrinks the policy space, moving the centre ground of programmatic competition between parties further towards neo-liberal economic strategies and policies. These and similar analyses are more concerned with globalisation's implications for public economic and social welfare policy than for party politics and aspects of the party system other than policy convergence, even if they do have some relevance outside advanced post-industrial democracies with their strong social democratic traditions. Even the writers in international political economy who say globalisation should not be viewed as a dominating and independent variable and argue instead that the state exercises an independent influence on policy in the main ignore the party dimension. A tiny literature on developing countries suggests that even there collective action can make a difference to the policy mix, influencing it in a pro-poor direction, for instance Kurtz's (2002) comparison of post-Pinochet Chile and Mexico under the Institutional Revolutionary Party. Kurtz accounted 
for the differences in welfare policy regime in terms of party system dynamics and levels of political inclusiveness.

9 Pridham, who has investigated these matters most closely, found transnational party co-operation in East-West Europe 'has played a not insignificant although low-profile part in the democratization process at the level of party development' (Pridham, 1999a: 73).

10 The role of external support to parties, human rights organisations and other forms of organised political protest against pre-democratic authoritarian regimes in countries such as President Pinochet's Chile has already been the subject of some attention. See for example chapters in Whitehead (1999); also Keck and Sikkink (1998).

11 Data from Piano and Puddington (2006), based on events December 2004 to November 2005. 'Free' countries are those with combined ratings for political rights and civil liberties that average 1.0 to 2.5 ; 'partly free' countries average 3.0 to 5.0 ; 'not free' countries average 5.5 to 7.00 .

12 The Centre for the Study of Globalisation and Regionalisation (CSGR) globalisation index for 2001 ranks Turkey in 28th position; available at www. warwick.ac.uk/fac/soc/csgr/index.

13 Ladrech (2002) proposes an analytical framework to assess the impact of 'Europeanisation' on parties but does not prejudge the empirical findings, other than maintain that 'Europeanisation' need not mean convergence or harmonisation. 


\title{
2 Political parties, international party assistance and globalisation
}

\author{
Peter Burnell
}

This chapter introduces the challenge facing international democracy assistance in its endeavours to support political parties' contribution to democratisation, given the constraints and opportunities posed by globalisation. To understand the role that democracy assistance can occupy here, it is first necessary to identify the relationship of party politics to democratisation, before going on to distinguish the different approaches that assistance can take. The chapter explores what globalisation means for the challenge of establishing democratically effective parties and party systems in new democracies, distinguishing potentially positive and negative effects. Some implications for how assistance to party-based democracy might respond are raised in Chapter 11.

\section{What political parties do}

From the perspectives of democracy and democratisation party politics is not an end in itself. Although the purveyors of party aid have the development of parties as their primary object, it is what parties do (or cannot do) for democratisation that is of more importance. Parties collectively provide public virtues for democracy, but individually the parties and the politicians who make them work have private vices - power, and the various purposes to which they want to put power, are the main motivators, and a disinterested commitment to advancing the cause of democracy may not feature high on everyone's agenda. That said, there is a distinction between parties and party systems. The latter refers to the number and distinctiveness of effective parties, and the nature and extent of their differences, such as whether highly polarised or not, their relations to one another and society. And it is the institutionalisation of the party system that may have the greater significance for the quality of democracy and its consolidation in the long run (Mainwaring, 1998). ${ }^{1}$ However, as Randall and Svåsand (2002a) have shown, what tends to be understood by institutionalisation in respect of parties may not coincide with institutionalisation - or its requisites - at the level of the party system. Indeed, the two may actually conflict. Other useful distinctions are between 
the attributes, capabilities, roles and functions of parties. The last can refer specifically to functions for democracy and democratisation. To say that if parties gain, for example, from international support, then democratisation must advance is a non sequitur.

Whereas what parties really do and the consequences of their actions are matters for empirical inquiry, questions about what they should (be helped to) do cannot be answered fully outside some normative framework, such as one that identifies democracy's meaning, purpose and value. In short, what is democracy for? Why is democratisation a good thing? The responses to such questions are bound to vary. Some lay emphasis on the provision by parties of means for people to participate in the political process (participatory function), although views differ on why that is so important - ranging from fulfilling the requirements of representation to the belief that participation develops good citizens (educational goal). Yet others place more weight on the ability of competing parties to make elected government accountable (control function), in the interests of securing government that both possesses legitimacy and tries to practise good government. These functions are a sub-group of a wider set of roles that are associated with parties but may not be exclusive to parties or even unique to democracies. Examples are the recruitment of effective leaders for public office, policy formulation, expressing social solidarity and furthering the cause of social and political integration by influencing how citizens behave. Parties may also do the 'vision thing', that is, articulate a view of the kind of society that is desirable, which can vary widely from, for instance, ideas about social justice to ethno-nationalist purity. In the democratic context a constantly recurring theme is that parties supply the main bridge between state or democratic governance and society or the citizens, and that this lies at the heart of their contribution to both national integration and democratic consolidation.

In order to perform any of the roles and in particular the functions for democracy and democratisation, parties and party systems need certain capabilities. For example, policy research competence is needed if parties are to be able to review and initiate solutions to problems arising in the public sphere. Capabilities in turn rest on the possession in some measure of a number of attributes, properties or qualities, such as financial resources, organisational strengths, communication skills, public trust and so on, all of which might be deficient, especially in the early days of new parties or brand new democracies. In respect of the party system, continuity of some of the parties over time is desirable if the voters are to be able to enforce accountability through periodic elections, although a stable party system does not require the entire membership to remain constant - indeed, that can be a drawback for democratic development. Furthermore the roles most commonly associated with parties and party systems in the established democracies may not be identical with the functions that party politics can - must even - perform for democratisation. 


\section{Peter Burnell}

This is the difference between running politics in a stable democracy and helping to move the polity towards democratic consolidation, however defined. ${ }^{2}$ So, for example, while helping parties to become effective at conducting election campaigns could be essential to a democracy, it will not necessarily further democratisation, especially if the parties themselves are not all committed to democracy's purposes, values and practices. Conversely, there is the failure to promote civic education that has recently been diagnosed as a specific weakness of the parties in the established democracies. ${ }^{3}$ While not necessarily threatening the persistence of democracy in Western Europe and North America, such failure might be cause for much greater concern in emerging democracies that lack other instruments to perform this vital task, and where there may be no historical memory of widespread democratic participation. Democratisation could be at risk.

Debates over which of the parties' roles or functions can be said to be 'core' and which ones only parties (or certain kinds of party) can perform - and which activities are merely ancillary ones that certain historically contingent forms of party have contributed in the past - provide useful distinctions, all of which may need to be revisited from time to time and recast in the light of a globalising world. We should not assume that the division of labour between different categories of organisation is - or should be - set in stone, ${ }^{4}$ although apart from competing for public office and furnishing governments (and even then it is not unknown for political figures to be elected to high office without having strong party credentials), there is much room for debate over where the comparative advantage of parties does now lie. For instance, while it has become very common for an assortment of civic associations to articulate particular interests - a role formerly assigned to parties - interest aggregation might be considered to be both a higher order requirement of democratic politics (albeit one that depends on interest articulation) and a democratic function where parties collectively still (should) have the edge. This is neither to say that parties monopolise the role nor to deny that certain types of party, ethnic parties for instance, make very poor candidates and may behave dysfunctionally for democratisation. ${ }^{5}$ Put differently, it is for parties to unite society and contribute cohesion whereas at least some civil society groupings and new social movements might prove more conducive to societal fragmentation. In divided societies seeking to establish democracy out of the ruins of violent conflict, interest aggregation is one of those most vital public goods that can easily be undersupplied. That gives the construction of party politics there a special mission, and one that has significant implications for determining the best form of party system. To illustrate, collusive inter-party relations may facilitate democratisation through a transition period. But if that arrangement creates a static and restricted pattern of political competition that leaves wide open spaces for the rise of 'anti-system' parties (parties that do not subscribe 
to democracy and the rule of law), then the consequences could be less favourable to democracy later (Norden, 1998).

If what parties do and what the parties look like cannot be separated from one another, then inevitably the border between parties and embryonic parties, proto-parties and other party-like organisations may be as fuzzy in practice as it is intriguing in theory. At minimum, parties seek public office. But judging which civic groups, social movements, protest movements and other sorts of collective actors in political civil society will develop into parties during major episodes of political regime change can be every bit as hazardous as forecasting which new parties will go on to thrive, or wither away or suddenly collapse. In reality, the emerging and prospective new democracies differ greatly in respect of both their present condition (from dominant party systems to very fragmented party systems) and the antecedents, which vary as widely as no-partyism (as in Uganda's experience of 'movement politics' under President Museveni) to some of the post-communist cases where a de jure one-party state suddenly gave way to a very fluid situation and ongoing flux of the parties (some might almost say a non-system, for example, in Poland). In many countries brand new parties are formed but have to coexist alongside other parties that, in one guise or another have been very significant actors in the past. But in contrast to situations where opposition-party led dissent contributed strongly to the redemocratisation of an authoritarian regime are the episodes of democratic breakthrough in which political parties were not major actors at all, possibly because they had been ruthlessly suppressed.

\section{Strategic approaches to assisting parties' role in democratisation}

Identifying what parties and party systems actually do in today's established democracies is not the same as conceptualising their roles and functions for democratisation. The order of importance among tasks and the sequencing during the larger processes of political change may differ among societies, from one phase or episode of democratisation to the next. If external actors are not to overload the absorptive capacity of parties to receive support and the demands placed upon them it may be essential to establish some relevant priorities. Van Biezen (2003) has argued that the sequence of events in democratisation can influence the sequence of organisation building by parties and the incentive structure concerning whether or not to invest in developing the party on the ground. The timing of the creation of central party organisation vis-à-vis popular involvement may mean the difference between a largely instrumental approach to political mobilisation by political elites on the one side and a more grass-roots approach to participation in ways that hold party leaders to account on the other. An analogous chain of reasoning would suggest that the sequencing of activities that party politics actually performs 


\section{Peter Burnell}

could critically affect how well and in what ways it serves (or hinders) democratisation. Knowing the optimum balance of roles and functions at any one time and getting the timing right are challenges for designing party support just as they are for the parties themselves. In the course of political development parties and their international friends should be prepared to make adjustments in the contribution they seek to make to democratisation, especially if they find that the particular strengths they previously offered or supported are now outmoded or have become inadequate to the evolving new requirements.

In Chapter 4 Carothers paints the reality that although much international party assistance is founded on a shared idea of what a good party looks like, it has little strategic sense of what is to be expected at the end of the process of party support. Setting out in this way by prescribing a universal model of what political parties do and then seeking to advance that model irrespective of time, place and circumstance has the appeal of simplicity. The same is true where there are firm assumptions about the respective worth of the different roles and functions that party politics might perform, for instance a conviction that maximising participation should take precedence, and that furnishing stable national political leadership or providing effective economic management should always carry lesser weight. However, there are at least two alternatives to such simple ways of proceeding. One is a stageist approach. This maintains that the requirements that democratisation needs most from party politics and the optimum order in which specific functions should be prioritised will vary according to the stage or level of democratic development already achieved. For example, holding government to account might become one of the most important functions in the longer run, and that in turn might be served best by encouraging an adversarial form of party politics underpinned by the notion of a democratically 'loyal opposition'. But to seek this might be appropriate only after other basic features of democratic stability have already been achieved, especially if vehicles for social reconciliation and political integration are in short supply. And that in turn could invite approaches to party system engineering that lean more immediately towards a form of consociational or consensual politics (Reilly, 2003).

The second option - and seemingly more democratic approach to strategising party assistance - is to say that the people themselves must decide. This is an appealing answer when considered against the background of those critiques that characterise international democracy assistance as being too supply-driven (that is, donor-driven) and excessively prone to elite-led, top-down initiatives that smack more of imposition than popular ownership. An illustration of this is the complaint made by local partners in Serbia and Montenegro that 'some donor activity is designed to meet objectives set in Washington, London or Berlin' (River Path Associates, 2005: I, 74). But the alternative could mean canvassing the 
different social groups' views on democratisation, the value they place upon it and why and what they most expect to gain, and how they conceive the contribution of party politics to this process. We should not be surprised if a variety of answers as uniquely meaningful as peace, prosperity, liberty, empowerment and social justice actually frame the respondents' replies. The practical difficulties of 'asking the people' should not be underestimated either. In more authoritarian climates the conduct of truly revealing attitude surveys is problematic. People's views about democratisation and more particularly the role of parties may differ depending on the time horizon they are asked to consider. And views could change over time, not least if the political situation develops and (for good or ill) society becomes more familiar with the operation and the actual merits and disappointments of political pluralism in the interim. Moreover, it would be important to access the views of ordinary people, including the politically unengaged, and not just the political elites. After all, the party leaders (some of them, at least) may themselves be part of the problem, harbouring attitudes inimical to democracy, even though strengthening parties is a crucial part of the solution to democracy's weakness. Thus in Bosnia-Herzegovina, for instance, the UK's Westminster Foundation for Democracy has observed the persistent domination of parties by their leaders and undemocratic decision-making, leading it to believe that the way to challenge excessive ethno-nationalism in Bosnian politics is through changing the outdated, communist-style models of party organisation that sustain it (River Path Associates, 2005: I, 60). Of course, none of this gives specific guidance over what to do in situations where the party elites obstruct change or where survey respondents prove suspicious of or even hostile to democratically organised party politics other than to suggest that such societies are not the most obvious candidates to receive international democracy support. Alternatively, democracy assistance in such places could concentrate first on exploring the reasons that lie behind such unfavourable attitudes, and tackle what may be more fundamental democratic deficits than political party issues, perhaps giving priority to addressing even more serious weaknesses such as state collapse or the breakdown of law and order.

\section{The parties dimension of democracy assistance}

What might party aid do that could help party politics serve democratisation or more indirectly improve the conditions that in turn influence how far parties and party politics can live up to the requirements of democratisation in a globalising age? A preface to an answer should perhaps say that whatever else is considered all initiatives must be grounded in a sound understanding of the principal determinants of the number of political parties and other key features of a party system. However, in such matters as the respective weightings to ascribe to the influence of domestic 


\section{Peter Burnell}

structure and agency, the importance of institutional conditions and preconditions (formal and informal) and the shadow cast by history - the preceding regime and the manner of democracy's coming (violent, 'pacted' and so on) - the literature on party politics shares much of the ambivalence found in theorising about democratisation generally. Party politics seems to take its shape from a complex web of 'causes': no single general theory is trumps - instead there is a well-tilled field of partial and contested propositions and middle-range debates. This means that democracy assistance faces several options for supporting the growth of party-based democracy. The following account indicates a broad menu of possibilities; a more detailed assessment of what has actually transpired can be found in Chapter 4.

\section{Parties at election times}

In the past much support has gone on an ad hoc basis to selected activities by parties as and when the immediate need has presented itself, most typically in 'founding/transition elections', the most pressing being the capacity to campaign for electoral support. There was probably little thought about the consequences in terms of party system or more subtle democratisation objectives for the longer term. Although decidedly opportunistic and short term, such interventions can still be appropriate where the success of just such an election - or perhaps even a specific electoral outcome (victory for pro-democratic forces) - and the formation of a legitimate government in this way are critical to the chances of completing an orderly changeover to democracy. Much of the party support has taken the form of advice and training although there have been instances of financial transfers, too. But much of the large scale international financial assistance has been reserved for making elections possible, by underwriting the infrastructure for organising the electoral process and staging elections, without which party competition would be meaningless.

\section{Parties between elections}

Kumar (2005: 520) reckons that probably more resources continue to be devoted to election campaign-related activities than any other party object. But with the move from a democracy's inauguration towards placing it on a secure footing and improving the substance - most notably in ensuring that electoral democracy blossoms into liberal democracy complete with universal respect for wide-ranging civil liberties and minority rights - the organisational development of the parties starts to attract more attention. This means support for objectives such as organisational durability and structural innovations to promote intra-party democracy, and entrenching equal opportunities (or, possibly, positive discrimination) for women. 
Given that what parties do between elections is so important to democracy, offering long-term support that both helps build a firm base in the country and supports effective participation in the legislature can have particular value where the country's political constitution inclines towards executive predominance (a feature even of some parliamentary systems). That tends to give incentives to parties to spring to life at election times only. Cross-party projects such as those that aim to influence political behaviour across all parties, for example in countries coming out of violent conflict, also are as much about the party system as parties individually.

In reality, however, the evidence from some countries attempting to build democracy after conflict - Mozambique, for instance - is that democracy promoters have shown more willingness to offer support to parties as a peace-making strategy, operating with a short-term horizon, than to follow up afterwards with substantial sustained assistance for the longer haul (de Zeeuw and Kumar, 2006). Nevertheless, a rather distinctive mission that international actors can volunteer at the outset - Northern Ireland (Sinn Féin) and Palestine (Hamas) are topical examples - is to persuade any parties that have links with movements that practise or have practised political violence to sever their links with those organisations and/or renounce the use of violence, so as to help build social capital among the different politicians and ensure that democratic political participation alone will prevail.

\section{Institutional influences on parties}

A third option is to address the wider institutional context that influences not just parties individually but the party system, with a view to achieving a multi-party system that is both inclusive and competitive. That can mean advising on the technical specifications of alternative electoral systems (although the ability to determine the party system through tinkering with the electoral system should not be overestimated), and rendering technical and financial support to the office of elections management (professional competence and political autonomy there being essential). Investing in a credible apparatus for non-partisan management of the entire electoral process can be important for preventing manipulative game-playing by some parties who, just because they know they are relatively unpopular, will cry foul and, possibly, boycott an election, or alternatively dispute the validity of an election after another party is declared the winner cynical tactics that can erode public confidence in, and support for, the politicians generally. In some countries influence might have to be brought to bear on the government to liberalise the framework of laws and regulations if it restricts unduly the association, assembly and registration of parties by political opponents.

That larger constitutional issues might also have to be considered in this context is illustrated by the conventional understanding that the more 


\section{Peter Burnell}

highly presidential the system the weaker will be the parties - something that can drive elected members of the legislature to concentrate on doing local constituency work and become increasingly divorced from nationally important international affairs. The timing of presidential and parliamentary elections (concurrent or otherwise) may modify these effects on how important a role the parties play. But of all the different institutional influences the funding regime for political parties is the one that seems to have attracted most interest from external democracy promotion actors, although on this it is much easier to give advice than to be confident that any democracy anywhere has found the ideal solution (see Burnell and Ware, 1998; International Institute for Democracy and Electoral Assistance, 2003).

\section{Social and cultural engineering}

Of course, very different and less direct approaches to influencing the development of party politics are indicated if the social cleavages structuring political representation are believed to hold the key, or if the main emphasis has to be on changing political attitudes. On the former there is some support for the idea of greater collaboration between democracy assistance and the efforts in more conventional international development co-operation, for instance with a view to achieving more equal political participation by differentially advantaged/disadvantaged socio-economic groups. However, the danger is that democracy assistance and its distinctive objectives might then become harnessed to the cause of economic development because of the vastly greater financial and human resources and the leverage that traditional development aid bureaucracies invariably possess. And the fact remains that in many of the developing world democracies left-right distinctions based on income, wealth and occupation are relatively unimportant or must compete with other stronger forces shaping political allegiance, such as ethnic and linguistic factors. Yet although it is in parts of post-communist Europe (and Latin America) that the influence of class, occupation and related considerations on voting behaviour and on party system development might be thought likely to be strongest (stronger than in Africa, anyway), party system outcomes even there have been influenced by the interventions of agency and party strategy. These appear to play a role in shaping 'underlying' social cleavage formation and people's perceptions about the social cleavages, too. So we should be wary of dramatising severely independent variables whose effects on party politics are (mis)conceived to lie wholly beyond the capability of international party aid or other external interventions to affect.

In respect of civic education, there may be opportunities for constructive involvement by democratic assistance in activities as specialised as the redesign of school curricula or devising regulatory frameworks for public service broadcasting. Encouragement to strengthen the legal backing 
for basic rights and freedoms such as the rights of women and vulnerable minority groups can also be highly relevant to the parties. And the aphorism familiar in the democratisation literature that claims 'no civil society, no party politics' directs our attention back to civic associations and to cultivating stronger relations with the parties. This is an endeavour where parties may be able to learn much from the greater experience that some civic actors and non-governmental organisations have in dealing with global networks and in treading the corridors of regional or global institutions of governance and power. Party-civil society relations are very much on the contemporary agenda of some democracy support agencies (Gershman, 2004; Kumar, 2005: 523).

\section{Inter-party relations}

A further possibility is to pay more attention to the relations between parties at both the national level on the one side and in supra-territorial forums on the other. At the domestic level the objective is to help with the construction of a party system in which the competition between the parties is neither so combative nor so collusive as to put democracy in the long term at risk. The development of amicable cross-party dialogue might lead on from agreeing on matters such as codes of conduct to considering how institutions such as the arrangements for political funding might enhance party politics' capability to serve democratisation more effectively in the future. At the same time there is some evidence that, if given the choice, many parties prefer to receive bilateral aid to sharing support in collaboration with other political parties or with civil society organisations.

Investment in the development of transnational party relations among countries facing comparable challenges in democracy building and similar pressures from economic forces of globalisation and institutions of global or regional governance (Chapter 8 gives African examples) is an option that receives little support in practice. But practical opportunities for parties in new democracies to co-operate and coordinate transnationally among themselves might enhance their ability to engage with the international democracy promotion organisations and party aid practitioners specifically on more equal terms. Clearly whatever is done at these levels should not be at the expense of levels below the national state. Indeed, in post-conflict environments it is often at the sub-national and local community level that real advances in peace building are - or must be made. And the encouragement that international donors with 'governance' agendas are giving to programmes both for privatisation and administrative decentralisation makes the case for corresponding initiatives to assist political society at sub-national levels that much more compelling. Indeed, there is a view that where it has been adequately constructed local politics can still promote a meaningful form of democracy even if in national state 


\section{Peter Burnell}

terms the forces of globalisation are now restraining what historically was a significant social force for democratisation, the nationally-organised working-class (Harriss, Stokke and Törnquist, 2005). However, the fact that the challenge - even at levels below central government - is anything but straightforward is apparent from Gallagher's account of the Balkans (see Chapter 6). Well-intentioned interventions by external actors such as the European Union appear to have fuelled political fragmentation, which now obstructs the construction both of strong democratically organised parties at the national level and effective central political authorities.

In conclusion, none of the above options for engaging with the sphere of party politics are mutually exclusive, although some involve working directly with parties whereas others concentrate more on changing the surrounding conditions. And there is a possibility that different kinds of involvement by external actors will operate at cross-purposes. Of course doing nothing should not be ruled out either, for it is a legitimate question to ask when/where is not the right time or place to party. The absence of (prospective) suitable partners suggests one such situation. Another is where there is a real risk of delegitimating party politics altogether through association with foreign interventions and especially where anti-foreign sentiment already runs strong. We should reflect on situations where 'pushing the envelope' for political parties could breach the principle of 'do no harm', and on circumstances where attention to parties simply will not touch the underlying determinants of a highly unequal distribution of political power. By offering a distraction, party support could jeopardise strategic thinking about alternative approaches to promoting democracy. But for all the courses of action (and inaction) that have been identified it is reasonable to say that in the endeavours of the democracy assistance practitioners a limiting horizon tends to stop at the national state, and globalisation's other implications hardly feature at all.

\section{How does globalisation impact on political parties?}

Globalisation's impact on party politics is a dauntingly large and complex topic, our understanding necessarily contingent on what we mean by globalisation and on distinguishing direct, first-round effects from any indirect consequences that follow from its impact on the wider political, social, economic and cultural parameters. The effects will not be uniform across all societies or all parties. Distinctive issues face parties in countries that are formally pooling certain powers of political self-determination to regional or other supraterritorial institutions of governance, the European Union for instance. But the overbearing force that some of the more populist accounts attribute to globalisation should put us on guard against undervaluing the influence of domestic sources of party weakness or party strength; we should not rule out the possibility that parties may make use of globalisation to their own advantage, just as they manipulate external 
recognition and other forms of international support (including democracy assistance) to advance their own particular interests within the domestic political arena. Put differently, if, as at least some of the literature already recognises, states still mediate the impact of globalisation and are one of the factors constitutive of globalisation, then research may discover similar findings about party politics rather than just number party politics among globalisation's effects.

More illuminating than posing one simple question about whether globalisation is favourable or unfavourable to the institutionalisation of party politics would be a willingness to disaggregate globalisation's consequences for different aspects of party politics, such as by investigating the specific consequences for how the parties conduct themselves, the party system, the policies they offer the electorate and so on. Exactly the same point applies to very narrow specifications of globalisation, such as the definitions that reduce it to a purely economic process, compared with globalisation in its entirety, which could be more enlightening. So, for example, there is the familiar claim from the established democracies that responses to globalisation and economic marketisation specifically have brought a narrowing and a rightwards shift of the ideological spectrum offered by the parties. In addition, the parties themselves have changed away from the 'catch-all' type and towards a 'cartel' model (Blyth and Katz (2005). Other analysts have offered slightly different views, for instance Kitschelt (2004: 21), who shares some of the concerns about the implications of globalisation for social democracy but says parties and party systems are evolving 'from encompassing department stores to specialized boutiques, as consumer demands become more discriminating: from the diversified task structure of holding companies to a concentration on "core competences" and comparative advantages .... Indeed globalisation's multifaceted nature combined with a discerning approach to investigating its effects may reveal both bad news and good news for party politics in emerging democracies. In fact, it is entirely possible that a particular feature or similar features of globalisation might have both some positive and some negative effects. These claims are illustrated below.

\section{Bad news}

The role of political parties as bridge between democratic governance and society is being undermined at both ends

One of the major political themes in the globalisation literature is that as power is increasingly being exercised on a trans- or supranational basis so political power is being externalised or 'denationalised', and in some respects is ebbing away from the state. The simple idea that power is shifting to global and other forces outside the control of states individually and collectively is certainly not endorsed by all analysts - some 


\section{Peter Burnell}

emphasise more the transformation of the state, and a few even point out how globalisation may be reinforcing or augmenting, as well as displacing, state power (Weiss, 2005). And yet even in the transformationist camp there is some recognition that many developing countries are less favourably situated in this regard. More particularly, then, specified powers and authority over agenda-setting, rule-making and rule application in certain vital public affairs are being transferred to multiple sites of governance situated outside, above and even below central government. With the coming of what has been called a 'global governance complex', state autonomy in many countries is in decline at least relatively, even if not every state in the world is seeing its power decline absolutely. Many of the emerging democracies and especially the smaller, weaker and poorer states have most reason to feel exposed. For example they can find in their dealings with the Bretton Woods institutions that even when those institutions' enormous financial leverage does not of itself demand compliance with the policy advice they offer, they do nonetheless influence how policy discourse on the management of economic and financial affairs is framed at the national level. It is easy to see how all this can engender concern about the limits of democracy possible at the state level and about the threats to democracy from the activities of non-accountable mechanisms of governance that have arisen in the world outside. This has ramifications for party politics.

Almost everywhere and certainly in democratising countries of Central Eastern Europe and Africa observers claim that the parties' connections to state and government either already do dominate, or are coming to dominate, vis-à-vis the parties' links with society. Even in the longer established democracies observers such as Katz and Mair (2002) note that the 'party in office' or 'parties in the state' are now in the ascendancy over the 'party on the ground', the 'party in the country'. As political elites become more dependent on the state, not least for resources for the party, so they sacrifice - or do not even attempt to cultivate - a solid basis for the party in society. In some non-Western societies this state of affairs is intimately connected with the greater displacement that neo-patrimonialism and the role political patronage have in party politics.

The great irony is that the movement towards a relatively closer relationship of parties with the state than with society is happening at the very time when the ability of many states and/or their entitlement to rule independently within their own territorial domain appears to be fragmenting, losing purchase or ebbing away. As elites fall in with the state more than with society, so globalisation appears to threaten their ability to use the instruments of state to deliver the public good (or, perhaps, even to use public projects for partisan political gain). Governments of many developing countries, even those that are not oil-rich exporters, formerly were able to rely on import tariffs and similar trade-distorting measures to provide revenues that would underpin the politics of patronage 
or fund larger developmental purposes. The parties in office derived some political benefit. Increasing trade liberalisation driven by the World Trade Organization (WTO) has now eroded that facility.

All in all, not only do party leaders now seem to be more remote from societal control, but the very institution they choose to align with (the state) may be coinciding less and less with the real sites of power. At minimum, far more is now required of the state's role as a filter or buffer towards the rest of the world, even if that role is not being brought into question in identical ways or to the same degree everywhere. This contradiction is sharpest for many of the newer democracies, who can claim little responsibility for the decisions made at global and regional levels that lie behind the vesting of powers in supranational institutions of governance. In so far as governing elites are actively engaged in managing these external relationships, their autonomy and power vis-à-vis their own party and not simply of the parties vis-à-vis society seem bound to increase with regard to the state's business and the party management and party policy-making. This is part of what Poguntke and Webb (2005) call the 'presidentialisation' of politics.

\section{'Choiceless' democracy'}

The irony noted above is being compounded by deliberate manipulation. Political parties - more especially parties in office - are not shy of using the presence of external influences and the existence of extra-national agencies of restraint to structure and confine the policy and institutional choices they offer to electorates - while disowning responsibility for any outcomes that seem likely to provoke dissatisfaction (the retrenchment of public sector workers at the behest of the IMF pressures to reduce recurrent public expenditure is an example). This kind of scenario undermines political accountability and is not unfamiliar in the heavily indebted states that are most beholden to the Bretton Woods institutions and other foreign creditors, whose 'discourse power' may be deployed by governments to assail the credibility of their domestic political opponents. But similar tendencies to what Mkandawire (1999) called 'choiceless democracy' have been detected in other countries too. ${ }^{6}$

At the same time some of the institutional reforms that the international financial institutions typically require in return for their support aim to improve public sector efficiency and effectiveness. This can mean an increase in some of the capabilities of government to exercise control. An example is regulatory authority over economic activities and over those in the informal sector especially, with an increase in tax-raising powers being a particular example. The term 'capacity-building' is often used to describe such endeavours in international development co-operation; the World Bank actually characterises some of its activities as 'strengthening 
governance' even as it aims to secure a 'downsizing' of the state, to the end of creating a more favourable political environment for the working of the economic market. Meanwhile the political elites' own position relative to the rest of their party, its middle-rank officers and grass-roots activists may also be enhanced, such as when the benefits of privatisation programmes are shared out among the top leadership.

The claim that globalisation's neo-liberal economic agenda reduces the scope for parties to differentiate among themselves in terms of economic policy is part of this debate. There is disagreement in the literature on advanced post-industrial democracies over how far and in what respects policy choices regarding social welfare are actually being constrained. And even with respect to some developing countries it has been argued that even though closer economic integration narrows the policy space, some room for policy variation still remains (Kurtz, 2002; Mosley, 2005). Be that as it may, one of the consequences that Mkandawire (1999) and others bring to attention is the way parties may sometimes feel compelled to turn to other ways of differentiating themselves in the political market. At best the competition between parties may then revolve around their respective claims on competence to govern and reputation for integrity not an ideal solution for democracy if it is seen to privilege managerialism and technocracy over political debate and drives out engagement with alternative values-based perspectives on the public good. But there are other possibilities that can be much less benign for democratisation and/or for political stability, as when politicians resort to ethno-nationalist, religious or some other divisive platforms, for the purpose of mobilising support. In substituting for the programmatic void, the politics of communal identity and its most troubling manifestations such as sectarianism can fuel the potential for violent conflict even in societies that previously had been at peace (former Yugoslavia is an obvious example).

Yet if as a substitute for programmatic differentiation the language of competition between parties revolves instead around the personality of their leaders - something that looks fairly harmless - the outcome may be hardly edifying. It moves democracy closer to soap opera, or at best the rather minimalist definition Joseph Schumpeter offered in Capitalism, Socialism and Democracy (1942) that privileged occasional competition among elites for the people's vote. The approach of personalist-based parties that rely on emphasising populist credentials to pave their way to power may serve democratisation no better if the effect is to thwart the institutionalisation of political parties and prevent the emergence of a reasonably stable party system. ${ }^{7}$ It seems globalisation's effects on party politics could have larger adverse implications for democratisation than just its potential to influence the economic and social policies that parties pursue.

Furthermore, the thesis summed up as 'choiceless democracy' runs seamlessly into the belief that globalisation's economic manifestations are 
disempowering particularly for the most vulnerable sections of society: the very poor, disadvantaged minorities and women. It is their interests that are most likely to be underrepresented by political parties if the policy space shrinks and takes on a pro-market bias. Where globalisation in effect means material impoverishment for the very poor there is a strong chance they will be demobilised out of - or, more accurately, not mobilised into - politics. The preoccupation of addressing basic material needs takes priority.

Against this it can be argued that the 'post-Washington consensus', which from the late 1990s came to over-layer the neo-liberal orientation of the Bretton Woods institutions, exhibits a more sympathetic interest in meeting the needs of the poor. The current era of Poverty Reduction Strategy Papers (PRSPs) and accompanying 'process conditionality' bears witness to that. However even if this recent development has allowed political parties more latitude to incorporate pro-poor policies in their election manifestos (which some critics claim is only superficially the case), where this comes about in response to external prompting or pressure exerted through donor conditionalities, the question remains: what are parties for if they must dance to someone else's tune? In reality the picture is less reassuring. For so far the typical format of PRSP tripartite consultations that have involved international donors, national ministries of finance and civil society in many developing countries including in Africa have tended to marginalise the parties and legislatures, confirming a quasitechnocratic approach to policy-making with little democratic accountability to poor people. Parliamentary approval is not included among the terms and conditions of the PRSP process that countries that seek financial help from the World Bank and the IMF must now undertake.

\section{Globalisation increases complexity}

Globalisation as the compression of time and space makes the task of governing more difficult where growing interconnectedness and increasing velocity leave economies and societies more vulnerable to external shocks. It adds more burdens to the increasing complexity of public issues and challenges of governing that parties must be equipped to respond to. Whether or not the shocks were intended or planned is irrelevant. Wars spill over into neighbouring territories; world commodity price fluctuations impinge on the public finances; speculative flows of 'hot' money can reverse direction across borders without warning, dictated by machinations in the global derivatives markets for government bonds and currencies. Major (new) risks to public health such as the spread of HIV/AIDS or 'bird flu' can travel almost anywhere, virtually overnight. Increased vulnerability to international terrorism is yet another feature of today's more interdependent world. To be more than just passive figures in this landscape, political parties must be able to relate to solutions that can be 


\section{Peter Burnell}

highly technical; they have to be familiar with many different kinds of professional expertise. Parties cannot rely on purely political skills.

Moreover polycentric governance with its patchwork quilt of overlapping institutional mandates and gaps between organisational responsibilities generates areas of confusion and adds to this environment of complex uncertainty. Political parties have to be imaginative and adaptable if they are to maintain credibility. In place of parochialism, the ability to relate to regional and global policy networks becomes increasingly important. Of course, if something like an economic crisis leads to renewal and replacement in the party system because the existing parties show they have no answers, then the consequences may benefit democratisation (as Chapter 7 demonstrates, this has been the case in Turkey). But a collective incapacity by parties to offer an adequate response to the challenges posed by external events could be much more harmful, especially if society is then tempted to think that an unelected government, a militarybacked technocracy for instance, might perform better.

\section{Transnationalising civil society in the overtaking lane}

In the West some leading analysts of party politics see a weakening of traditional forms of civic engagement, erosion of the networks of trade unions, churches, farmers groups, business associations and the like. At minimum the ties with the parties, which used to root the parties in society, appear to be getting weaker. In a related and well-known claim there is Putnam's (2000) thesis on declining social capital in the US. An increasing individualisation of society is held responsible. However, in contrast to these propositions, the literature on globalisation detects the flourishing of an extremely diverse transnational civil society. Some of the writers chart the growth of international human rights advocacy networks in particular; others trumpet the rise of social movements. 'Nowadays,' says Ibarra (2003: 2), 'nobody would question the central role held by the social movement in the democratic game.' The great breadth of actors, international non-governmental organisations (INGOs) as well as non-governmental organisations within countries (NGOs) stretches from on the one side examples that work closely with global governance institutions such as the World Bank to those transnational groups of protesters, campaigners and radical social movements that claim to offer 'global resistance' to globalisation. Scholte cites evidence suggesting that in the last four decades of the twentieth century the number of active transborder civil society groups multiplied more than tenfold, to around 17,000; much of this increased mobilisation addressed global issues such as development, ecology, human rights and peace (Scholte, 2002: 149-50).

The totality of all these different kinds of groupings seems to have taken very much more advantage of the opportunities to organise and mobilise across borders in response to pressing issues of urgent, intensely felt 
concern than have political parties. Moreover, civil society sets out to 'make a difference' where it matters, such as by influencing the discourse, the institutional procedures by which policies are made and the policy content, all of which contribute to the emergence of post-statist governance. (Scholte, 2002: 152-9). These non-governmental actors are themselves challenging national territorial sovereignty as the exclusive basis for political community and identity, even when that object is not their primary goal. So:

Whether in terms of the democratisation of the institutions of global governance, the spread of human rights across the world, or the emergence of a global citizenry in a world-wide public sphere, global civil society is understood to provide the agency necessary to these hopedfor transformations.

(Baker and Chandler, 2005: 1)

For globalisation's critics the 'counter-hegemonic' side of global civic and social activism has special appeal in this scenario; by comparison parties do not get a mention in that regard.

Even at the purely domestic and sub-state level NGOs seem to have benefited from the attentions of international development and democracy assistance organisations. International financial and technical assistance to some countries has been directed away from central government partly in order to prevent the resources being abused for party patronage purposes. The most politically able and enterprising figures then gravitate to civic associations and spurn party politics. They are often more adept than parties at writing the kind of applications for international support that chime with the 'requirements' of foreign democracy assistance agencies. Indeed, there are democracy aid practitioners who say their concentration of democracy support on civil society has been harmful to party development, although this picture may not ring so true in Central and Eastern Europe at the present time, where Ágh (see Chapter 5) sees the parties as being partly responsible for the current weaknesses of civil society.

A positive outlook for transnational civil society may be potentially threatening not only to political parties but to democratisation, too. For one reason, it is difficult to predict how it can help states to recapture or retain the initiative against globalisation, even if many of the civil society organisations continue to succumb to 'nationalist, statist and territorialist mindsets' (Scholte, 2004: 230).$^{8}$ For another, even if transnational civil society is more 'wised up' than most political parties to the increasingly transterritorial nature of major public issues and to the new realities of global governance, it is far too soon to say they will rescue democratic objectives and serve democracy's purposes in this or some other way. Civic associations and social movements do not claim to represent all of 


\section{Peter Burnell}

society's diverse interests and opinions. They do not submit themselves to the electorate - an important ritual for bestowing legitimacy and imposing some veneer of accountability, however thin - in the way political parties or even independent (and anti-party) political candidates are prepared to do. While some NGOs are member-based and hold annual general meetings (something that can complicate the relations they have with partners from international democracy assistance) many are in fact elitist and not well grounded in society. In Scholte's (2004: 230) words they operate only 'very limited and unimaginative accountability mechanisms in relation to their own activities'. In many cases transnational co-operation among the NGOs and INGOs involves only a small cadre of leading personalities. An increasing number are co-opted by governance institutions through relying on them for a substantial share of their income. The consequences for their autonomy may far exceed the effects that state funding has on political parties.

NGOs and especially the new social movements are prone to wax and wane. But democracy needs at least some continuity in its political parties (that is, institutionalisation) if the promises they make to the electorate are to be taken at all seriously: perhaps paradoxically the likelihood of that increases where the parties have strong organisational linkages to society. If it really is the case that many politicians, officials, business leaders, journalists and academics currently ask why unaccountable civil society actors should have the right to influence the course of globalisation (Scholte, 2004: 232), then for parties to concede the field to these actors hardly bodes well for democratisation. At minimum it places a large question mark against the 'civil society first' approach to democracy assistance and the presumption that that entails, namely that when the time finally arrives for democracy promotion to prioritise the development of parties, democratic values and practices will flow into the parties from an already well established civil society base.

\section{Threat from transnational uncivil society}

The globalisation of organised crime is hostile to democracy. The transterritorial linking up of politically motivated actors with a commitment to pursuing their agendas by illegal and, in some cases, violent means is even more sinister. Al Qaeda, which sees itself as waging a global struggle, is only the most obvious example. The growth of such entities no less than the flourishing of civil society represents a failure by the political parties to offer adequate channels for expressing grievance and pursuing dreams. At the same time the apparent success of such organisations in terms of public profile competes with parties, potentially diverting support and resources that might have been available to party-building. Of equal concern is where the response of the parties is to embrace illiberal or anti- 
democratic orientations themselves, which is what can happen where they feel forced to compete with these organisations on their terms. Of course, governments that prohibit democratically organised party politics in the first place, or become more repressive towards parties as they take fright at the possible consequences of free and fair elections (as happened in Algeria in 1992), must share some of the responsibility. But situations like this strengthen the claims for party support to be included as a more prominent feature of international strategies to support democratisation. For such strategies now draw added impetus in the West from policy drivers that hope democratisation worldwide will offer an antidote to anxieties about international stability, peace and national security.

\section{Global communications networks displace parties}

The expansion of global media and new information technology diminish the parties' traditional role as sources of political information and oracles of guidance on public issues. Citizens can more easily compare and check the veracity of the messages the parties provide. More and more people can engage in politics outside the formal channels offered by political parties, courtesy of cyberspace. Also, parties now have to compete with the global 'infotainment' industry. Not having a captive audience, political parties now have to work harder to command the citizens' attention and influence their views.

In addition, the new communications mediums, most notably the internet and electronic mail, enable party leaders to reach party members and supporters directly and to bypass allies or intermediary levels in the organisation. The opportunities increase for power within the party to become more highly concentrated and for internal debate to be stifled (Katz and Mair, 2002; Blyth and Katz, 2005). This operates to the detriment of intra-party democracy and democratisation more generally. In fact the 'politics of mass society' (Kornhauser, 1959), a condition whereby political leaders can exert influence on an increasingly atomised society's attitudes and beliefs directly, without even going through party channels, may be more attainable now than at any time during the totalitarian dictatorships in inter-war Europe, for which period the term was originally designed. And yet the rise of the international entertainment industry made possible through multichannel satellite broadcasting and the like now competes not simply with political parties but with (involvement in) politics per se. Added to this, Webb (2005) and others see in countries such as the US and Britain a media that purveys unattractive images of politicians as largely self-serving, thereby contributing to a widespread lack of trust in politics more generally. The consequences for public cynicism and indifference, with fewer and fewer citizens relating sympathetically to party politics, may not yet be apparent in societies that are too poor to be comprehensively wired up or where the excitement of undergoing 


\section{Peter Burnell}

a democratic transition still prevails. But perhaps the portents for their future can be read off from what seems to be happening among postindustrial democracies in the West.

\section{Imported models can do harm}

The increase in global media and the ease of international travel expose societies to influence from contemporary Western models and techniques such as in the realm of electoral competition that may be inappropriate. Ottaway and Chung (1999), for instance, refer to an increasing and costly reliance on professional opinion polling and television advertising at the expense of deploying voluntary enthusiasm and volunteer labour. The shift conspires to produce merely electoralist parties rather than organisationally 'thick' parties. The new tools encourage politicians to concentrate on office-seeking for themselves rather than to labour long and hard to develop deep and lasting organisational roots for the party in society. Both the chances of party institutionalisation and the likelihood of parties making a worthwhile contribution to civic education are diminished. Kumar (2005) singles out for criticism USAID assistance to elections and electioneering. Even where financial transfers to parties are disallowed, the provision of material support may still risk creating external links of dependency that will hamper or distort party development.

\section{Good news}

A checklist of reasons why globalisation might be good news for the spread of party-based democracy can usefully distinguish between before and after democratic transition. Two points will be made about the former, followed by five about post-transition.

\section{Globalisation shifts the power imbalance in autocracies}

Globalisation that is understood to include cross-border collaboration among non-state actors and international support for opposition parties, proto-parties or other pro-democracy activists in authoritarian polities can embolden the domestic forces of resistance to oppression. Such actors can seek to exploit the 'boomerang effect' in the same way that some human rights advocacy groups have done to good effect (Keck and Sikkink, 1998). They encourage their friends in those democracies whose governments have some diplomatic leverage to lobby for international pressure to be put on their own regime. In consequence undemocratic regimes that are sensitive to their international legitimacy see the incentive structure changing: they respond not by raising the levels of repression but by increasing the political space in which pro-democracy activists can press their case (Yilmaz, 2002). Belonging to one of the political party 
internationals may be a starting point for the domestic opposition to have access to international channels in this way. For example, support from the party internationals and from Germany's Stiftungen was important to the success of the campaign inside Chile to end General Pinochet's rule and secure a return to democracy (Angell, 1996; Pinto-Duschinsky, 1996). In an example from Europe in the 1990s Pridham (1999b: 1233) observed that Slovakia's Democratic Union party benefited from expressions of solidarity from the Liberal International when it came under heavy pressure from an illiberal government.

\section{Globalisation transfers liberal and democratic ideas}

By eroding barriers to the free flow of ideas global communications networks contribute an opening to liberal and democratic values; and as channels for transferring guidance and advice they assist party formation in previously closed societies. Here again globalisation appears to threaten not so much the state but undemocratic governments or authoritarian regimes, potentially speeding the arrival of free and competitive party politics. To the extent that transnationalising advocacy networks of NGOs and INGOs by their words and deeds proselytise or display liberal and democratic values, their very example should help party politics develop liberal democratic characteristics. The point is especially pertinent to organisations whose mission quite specifically is to promote civil liberties and political rights.

\section{Transnationalising civil society and political parties as allies}

Even though in terms of addressing certain truly global issues a globalising civil society has some advantages vis-à-vis those parties whose inertia consigns them to remaining insular, there are many other distinctly national and sub-national issues for political parties to feed off, show their relevance and make their mark. In principle there is no reason why transnationalising civil social actors cannot take a lead in educating parties to apprehend more clearly the significance of globalisation for new issues, democratisation and party politics specifically.

In fact, transterritorial social movements and civic action groups could gain from enlisting the support of political parties on a national (or, indeed, transnational) basis, injecting energy and ideas along the way. This is obviously true where the advancement of their own objectives requires national legislation, and where political parties (those in government) provide the means and the formal legitimation. A strong and secure civil society needs effective, party-based democracy - one that offers guarantees against arbitrary state interference in the associations' internal affairs. Civil society does not make the state redundant; on the contrary, the (party-led) state is in part constitutive of civil society. 


\section{Peter Burnell}

Furthermore, the structure of global civil society almost inevitably reflects the deep inequalities found in the global political economy. So if the civic associations in many of the newer democracies are not to have their national or international agendas dictated by the greater financial, technical and political clout of their transnational partners in wealthy developed countries, then co-operation with their country's own parties could prove invaluable - by infusing or strengthening perspectives grounded in distinctively national or local concerns. Parties can add both authority and authenticity. Similarly, support from democratic parties may usefully protect the reputation and standing of civil society actors against their more illiberal or 'uncivil' counterparts at home and abroad. Assumptions that civil society will command respect where parties do not are not always born out by the evidence. ${ }^{9}$

Finally, the most radical fringe of collective action groups found in the broad anti-globalisation movement does not aim to influence public policy at all. As political parties seek to 'speak to power' they may feel no direct threat from such actors who turn their backs on institutions of governance. Of course, a dramatic increase in recruitment to anti-politics and, even more so, in predispositions to political violence by such a 'fringe' would pose serious questions not just for political parties but about the adequacy of the patterns or models of democratisation that are taking place.

\section{Globalisation and socio-economic change}

If, as many economists maintain, integration in the global economy is generally good for economic growth and development, and if, as most political scientists believe, development is beneficial to stable liberal democracy, then it seems that economic globalisation must be favourable to party politics, given the central place that party politics occupies in stable liberal democracy. But however impeccable the logic of this argument, more interesting is how the globalisation-development nexus impacts on parties and party systems. For instance, does the connection revolve mainly around increases in personal disposable income, or the possibility to divert increased leisure time into political activity, or perhaps around improved domestic communications infrastructures, urbanisation or some other intervening variable? Are the main democratising effects of development due to its role in changing social and political attitudes or through the impact on the social structure, instead? These are big theoretical issues: they matter because globalisation understood as greater market openness and a prospering global political economy produces both winners and losers, inside as well as between countries.

Growing material inequality within society is generally accepted to be one of the consequences even in countries whose economies on balance are benefiting from closer involvement in world trade and corporate 
investment flows. There is strong evidence for this from democracies as far apart as India and South Africa, Poland and Brazil. As globalisation exacerbates such divisions there may be opportunities for the political party system to reproduce something akin to the ideological-class basis to party competition in the West of old. Something like the 'golden age' of party politics that possibly existed in Europe's past might then be a future possibility. In fact, a trajectory along those lines might be essential if disillusionment with party politics is not to take hold among society's less privileged groups, for that could lead to declining support for democracy; even worse, the most disaffected may be mobilised into anti-system action.

Where the battle lines of inter-party contestation do come to circle around the politics of redistribution then the prospects for sustaining stable democratic politics might actually increase, especially if this prevents or displaces the most divisive expressions of identity-based politics. Conflicts over material issues can often be resolved by negotiation; sharp disagreements over such non-negotiable values as religious credos may prove more destructive. If the choices that are presented to the electorate offer competing ideas of market efficiency versus social justice instead of just differences between political personalities or a situation where political finance and mastery of the techniques of political advertising determine electoral outcomes, then there is a chance that society's respect for politics and thence the levels of democratic participation will increase. In that case democracy's value will rise accordingly. (Similar reasoning might be applied where it is the global and local environmental consequences of globalisation that capture the public imagination and structure political debate, with voters taking opposing political positions over the competing merits of the different economic and ecological trade-offs.)

The above reasoning does not sit easily with that strand of social science that sees globalisation as primarily a force strengthening the hegemony of transnational and global capital. It appears to suggest that the opportunity for democracy assistance to work with the emergence of social democratic (and, perhaps, green) political parties might yet increase, even as globalisation's pro-market effects give succour to parties of the right and centre-right that can draw practical support from business and trade associations and wealthy entrepreneurs. And where we see the emergence of parties of a diverse hue of ideological commitments, the scope for the longer established political parties in the older democracies to engage in potentially advantageous transnational party co-operation can only be of benefit, in contrast to situations where ethno-nationalist, neo-patrimonial and personalist-based parties make up a developing democracy's party system. The reality, however, could be much less straightforward.

First, of course, there has to be a belief that organising politically in this way can actually make a difference - that, for instance, parties with leftist inclinations or environmental agendas will be able to influence public 
policy notwithstanding globalisation and its consequences. Second, there are those post-communist countries where Communist Party rule still evokes some bad memories and impedes the sustained resurgence of genuinely left-wing parties. Third, everywhere much will depend on whether any increase in vertical (class-based) inequalities in society cuts across horizontal (identity-based) cleavages or, instead, coincides with and further reinforces those cleavages. The second of these alternatives is more likely to stoke conflict and put democratisation in peril. Chua (2003) goes so far as to argue that the spread of free market democracies is accentuating ethno-nationalism and contributing to ethnic violence by pitting poor indigenous majorities against prosperous market-dominant ethnic minorities. If that were true (and Chua's claims seem exaggerated), it only strengthens the case for developing democratic and soundly based party politics, where political leaders eschew irresponsible strategies of political mobilisation and stop short of the point where the drive for party institutionalisation prevents the institutionalisation of a democratically compatible party system (Randall and Svåsand, 2002a). Even so, in many less developed countries it is still not easy for the poor to organise politically - to go from being what Karl Max called a class 'in itself' to a class 'for itself' - compared to what happened during the first industrial revolution or what is happening now in the most dynamic of the developing economies. This is partly because levels of unemployment are extremely high, the poor often labour in seasonal work, and subsistence level activities in the informal sector are typical. Trade unions and their supraterritorial allies such as the International Confederation of Free Trade Unions do not reach down so far into society. In fact there is a widely held view that the increasing relative importance of international trade and investment for national economies must weaken the bargaining power of organised labour. That in turn weakens parties on the left, perhaps preventing any one of them from becoming thoroughly consolidated or giving them greater freedom to pursue vote-maximisation strategies that may offer few policy gains to the really poor. ${ }^{10}$ Yet even developments of this nature, while not encouraging to the left, need not necessarily prevent the consolidation of party politics in a new democracy and could make less likely a reversion to authoritarian rule, through a military coup, for instance. To repeat a point made earlier, there are different ways of assessing the contribution that parties and party politics can make to democratisation depending on timescale and the stage of political change and on which aspects of democracy or its main purpose are valued most highly.

Finally, the hypothesis that globalisation's tendency to exacerbate economic and social inequalities could lead some emerging democracies to experience a reverse wave of what happened in West, where 'standard' or ideologically based parties ('the golden age') gave way to 'catch-all' parties or even 'cartel parties', begs an obvious question. Why do we not 
see such a reverse wave happening now in Central and Eastern Europe as countries there undergo rapid integration into the global economy or - even more so - in the countries that are already among the most highly integrated, namely democracies such as Britain or the US where very sizeable inequalities in incomes or assets continue to increase? The welfare state arrangements these wealthy democracies have in place undoubtedly provide part of the answer. It remains to be seen if their explanatory power obsolesces as the domestic employment protection, social security and pensions regimes are weakened in response to the intensifying economic and financial pressures of an increasingly competitive global economy, as some observers claim is starting to occur.

\section{Bretton Woods bonus}

Historically, parties in government in many parts of the world have benefited from the willingness of international financial institutions and other foreign donors to provide loans and grants to governments for public purposes. Parties have been able to manipulate expenditure allocations and disbursements to the end of mobilising partisan political support. In some countries where neo-patrimonialism and patron-client relationships are strongly entrenched it has not been unusual for foreign aid to continue to fuel the ruling party's deployment of patronage even while trade liberalisation is eroding the government's fiscal base. The use of public resources to fund one or more political parties through illegal means can, of course, be considered a form of corruption even where not aimed at the financial enrichment of specific individuals. The Bretton Woods institutions and some bilateral donors increasingly try to combat this corruption as part of their drive for better governance, although the activities of some aid organisations and, more especially, elements of multinational business still seem to be pulling the other way.

As part of the great emphasis now placed on governance and the transfer of 'global best practice', the World Bank, the World Bank Institute, UNDP and INGOs such as Transparency International work towards applying pressure on the executive branches in debtor countries to become more transparent, by strengthening the mechanisms of both vertical and horizontal accountability. Although most of the programmes and projects to date have concentrated on the judiciary and civil society, there has been some modest support to capacity-building in parliaments. ${ }^{11}$ Although there is no significant evidence that such legislative strengthening has yet had much impact, more effective programmes would increase the incentives for politicians to invest in building sustainable party organisations. In theory, whatever enhances the scrutinising and monitoring roles that parties - opposition parties in particular - can play between elections, especially, should benefit the development of pluralistic and competitive 


\section{Peter Burnell}

party systems at the expense of transitory and ephemeral parties, unstable party systems and dominant one-party regimes. At the same time, where the institutional architecture of central government does allow all major parties a place in the public policy consultation process - if only out of recognition that they can influence the chances of successful policy implementation, or because government comprises a coalition - then party actors may be able to exert some influence on policy outcomes even where negotiations are being conducted with an organisation like the World Bank. Thus it has been argued that the effectiveness of this selfstyled 'knowledge bank' as a 'norm-broker' rests in part on its willingness and ability to construct supportive local alliances in civil and political society. In a country like Argentina, the Bank's coercive potential and ability to change incentive structures through applications of financial power by themselves do not guarantee the desired results. ${ }^{12}$ Similarly, the doubts that are now surfacing about the sustainability of contemporary strategies for poverty reduction are premised in part on a failure to place the mass of the people through their elected representatives at the heart of the process.

\section{Globalisation provokes political interest}

Globalisation's effects in some places demonstrate the capacity to stimulate the formation of nationalist parties and have led existing parties to adopt a nationalist theme, without necessarily creating xenophobia, racism or other potentially destructive tendencies. Members of society who might otherwise feel that party politics has nothing to offer are brought into the politically active citizenry and, over time, may come to take part in mainstream democratic politics directly. The relatively high levels of participation in the French and Dutch referenda on the proposed EU constitution in 2005 provide examples where the infiltration of anti-globalisation sentiment and concern about eroding national sovereignty animated voters and re-energised the political scene. The consequences have not given new shape to the party system as much as show that people refuse to be spellbound by the ruling elites. That is good for democracy.

In Turkey, where pressure from the EU to make concessions in the matter of northern Cyprus causes much resentment, manipulation of anti-EU sentiment to the advantage of right- and left-wing parties is less prejudicial to the democratic prospect than would be a return to more nationalistic displays of military rule. But Turkey's situation also reminds us that parties who represent sub-state regionalism or historically oppressed segments of society may have cause to welcome the encroachment of multilevel governance on central government if that development burnishes human rights in the communities they represent (most notably, in this case, the Kurds). And where they (or sub-state levels of government, a regional assembly for example) are able to gain direct access to supranational institutions of 
governance the recognition that follows can be instrumental to partybuilding. It may assist in the struggle to gain more adequate political representation vis-à-vis the central authorities in their own national state. ${ }^{13}$ Again, one effect may be to increase society's participation in party politics.

\section{Global funding opportunities}

More than ever before, the expansion of global financial services and tools of worldwide communications in principle enable political parties to raise much needed funds from legitimate sources far and wide. This includes fundraising both from political elites in neighbouring countries and from diasporas much further abroad, this last being a phenomenon of growing significance due to the significant place international migrant labour now has in the global economy. In some countries, such as Sri Lanka, entire families have settled abroad and yet continue to take a keen interest in the country's politics, and the migrant heads of household want to donate to party election campaigns. Naturally the question of whether they should have voting rights, too, is a very delicate one. ${ }^{14}$ While some countries prohibit political funding from abroad, many do not, and outright bans are difficult to enforce.

\section{Conclusion}

The three terms 'party politics', 'international promotion of democratisation' and 'globalisation' are all protean in meaning. The relations between the phenomena they refer to are variable, complex and mixed. There are no 'iron laws' to sum up the relationships, unless couched in the most general and least interesting terms. More fine-grained inquiry that takes the analysis down a level and studies specific cases is sorely needed.

Historically, accounts of what parties (are supposed to) do are much more clearly defined than the heavily contested discourse that now surrounds the relations of civil society to market and state. But we should not presume that the question 'what are parties for?' admits the same answer everywhere and across all time. Recent trends in globalisation and not just the way party politics has changed over many years inside the established democracies - are making a difference. Propositions claiming the state is losing all relevance as a result of globalisation are undoubtedly overdrawn; instead, empirically grounded accounts of what diverse states still do and can realistically aim to achieve (and how) offer more promising avenues for identifying how the two-way relationship between globalisation and states really affects party politics. Nevertheless, just as the question 'what is democratisation for?' is bound to elicit a range of answers none of which addresses the question 'what does globalisation achieve?', so these two major contemporary phenomena differ 


\section{Peter Burnell}

sharply in terms of what they need most from political parties. There is far more to investigating the place of party politics in a globalising world than simply disagreeing about what is happening to policy space. In the established democracies some of the roles traditionally assigned to parties may now be shared quite often with other types of organisation. But this does not necessarily offer an accurate guide to what should - or will happen in emerging democracies, where democratisation brings its own requirements. Furthermore, the available alternatives to political parties are not everywhere the same. The growing implications of extra-national, transnational and supranational influences on party politics in emerging democracies, and the role and performance of party support in international democracy assistance, in particular, are distinctive features of the globalisation of democracy in the modern era that merit greater and more detailed attention.

\section{Notes}

1 Although in Mainwaring's (1998) account of competitive-party-system institutionalisation at least two of the following four features refer directly to the parties themselves: regularity in patterns and rules of party competition; parties well rooted in society; major political actors accord legitimacy to parties; party organisations matter.

2 The meaning of democratic consolidation is highly contested. Accounts vary from minimalist models such as a general expectation that elections will remain 'the only game in town' to much richer versions that incorporate some notion of qualitative advance, greater 'democraticness' or democratic deepening. However, most analysts agree that democratisation involves more than just the routinisation of the electoral process as the method for forming governments, and must refer to other political institutions such as military-civilian relations and the status of the judiciary, the development of civil society and widespread socialisation into a democratic ('civic') political culture as well. Liberal democracy entails acceptance of the rule of law.

3 The survey of established democracies by Webb, Farrell and Holliday (2002) found that parties are failing most in respect of advancing a civic orientation among the citizens, owing to declining political participation.

4 Kitschelt (2004) among others notes an increasing differentiation of modes of collective interest mobilisation and intermediation among parties, interest groups and social movements, and increasing flexibility in terms of which of these vehicles citizens in the post-industrial democracies choose to use to advance the representation of their interests.

5 In Britain it is worth noting that Power to the People, 'An Independent Inquiry into Britain's Democracy' (Power Commission, 2006: 187), while extremely critical of the main parties because their members felt unable to influence policy, and because the parties were perceived to be too similar in their core policies and lacking in principle, nevertheless added: 'political parties are, when they are at their best, effective at presenting alternative ways to the electorate of aggregating diverse interests within their broad programmes and allocating resources to those interests. (Single issue) Campaign and interest groups do not do this - their goal is, of course, to espouse the supremacy of their particular cause and demand maximum resources to address that cause'. 
6 Mkandawire's (1999) reasoning, ventured in an African context, finds echoes in the literature on Europe (see Chapter 5). The EU, by constraining the freedom of member governments in respect of the policy alternatives they can offer voters, may be criticised for hollowing out party competition within the states. Even so, policy convergence can also represent a rational response by the parties to a movement in the preferences of a majority of voters towards the middle ground, as the electorate comes to concentrate on a narrow range of 'bread and butter' issues.

7 Mainwaring (1998: 74-6) places personalism in opposition to party rootedness in society; Gunther and Diamond (2001: 28-9) show why personalistic parties can only weakly perform the usual functions of parties.

8 Scholte (2004: 230) goes on to say the tendency to conceive 'of the political arena solely in terms of the territorial national state' is one of the greatest challenges facing civil society in obtaining more democratically accountable global governance.

9 In India, Chandhoke (2005) finds society has only minimal expectations of both the parties and civil society as agencies that will respond to their needs.

10 For contrasting perspectives on the linkage between trade unions and parties see Piazza (2001), who observes a weakening of union ties and social democratic parties, and Riethof (2004), who claims that in Brazil it was the growing political moderation of the labour movement that enabled the Partido dos Trabalhadores (Workers' Party) and its leader, Luiz da Silva, to win the 2002 presidential election. We can infer that organised labour's constructive role in bringing about Brazil's (re)democratisation has evolved away from the militant stance it adopted earlier against the continuation of military rule (which helped persuade the military to return to barracks) towards the stabilisation of competitive party politics now.

11 Examples are the UNDP/National Democratic Institute handbooks aimed at strengthening legislative involvement in the poverty reduction strategy process, drawing on collaboration with parliamentarians in Malawi, Niger and Nigeria and published in 2004. On line. Available at: www.accessdemocracy. org (accessed 31 January 2006).

12 Riggirozzi (2005) develops the idea that the Bank is a 'norm-broker'. In respect of structural adjustment programmes to liberalise the economy 'second generation' reforms such as reforming labour market practices require a more consensual approach than technocratic 'first generation' reforms (such as currency devaluation). The merits of a consensual approach may also apply to governance reforms such as tackling corruption. Parties may be able to provide support in return for opportunities to influence externally advised policy in a direction that makes some concessions to their demands and increases the chances of successful implementation.

13 Thus de Winter and Chachafeiro (2002) say elections to the European Parliament (EP) have provided a new political space that has helped ethnoregionalist parties by promoting cross-national networks and stimulating electoral alliances.

14 Estimates of the annual flow of remittances to developing countries and emerging economies from around 180 million expatriates range from the World Bank's suggestion of US $\$ 167$ billion to US\$300 billion (half of it through informal or unmonitored channels) according to 'payments experts' cited by the Financial Times 26 August 2005. On Sri Lanka, see Commonwealth Secretariat (2005: 29). 


\title{
3 Political parties and the democratisation of globalisation
}

\author{
Jan Aart Scholte
}

\section{Introduction}

What is the place of political parties and party systems in providing democracy for the more global world of the twenty-first century? If contemporary globalisation has shifted the contours of governance - that is, the ways that societal rules are formulated, applied and reviewed - do political parties need to reinvent their organisation and practices to fulfil their democratic role? If so, what kinds of adjustments are required? Or has globalisation so transformed politics that party formations have become obsolete in the democratic process, no longer able to deliver adequate public participation in, and public control over, the decisions that shape collective destinies?

This chapter argues that the past half-century of intense globalisation has by no means rendered political parties and party systems irrelevant. However, political parties - that is, formal organisations that support candidates for elected public office - have lost substantial democratic impact by failing to move on with today's more global times. Official circles and civil society quarters have generally made considerably more progress towards recognising, and adjusting their activities to, the shift from a statist to a polycentric mode of governance that has accompanied contemporary globalisation. In contrast, political parties have for the most part retained a now obsolete statist-territorialist-nationalist modus operandi. To the extent that political parties currently have only limited significance for democracy in global affairs, this situation has mainly been of their own making. Parties could regain considerable stature as democratic forces if they (belatedly) altered a number of practices in line with emergent polycentric governance of a more global world.

Along with this heavy critique of failings by political parties to date, the chapter also advances a number of suggestions to turn the tide in more positive directions. Such measures could benefit party organisations and wider democracy alike. Greater attention to global affairs, global rules and global institutions by parties could contribute significantly to their revival as democratic players. In turn, more globally oriented political 
parties could provide a much-needed boost to the broader democratisation of globalisation. The current general stagnancy of political parties and the overall underdevelopment of global democracy would thereby be addressed at the same time. Reinvigorated party systems are not a panacea for public participation and public accountability in global politics, but they could bring major advances.

The chapter elaborates this argument in three broad steps. The first main section defines key concepts ('globalisation', 'governance', 'democracy' and 'political parties') and summarises the consequences of globalisation for governance and democracy in contemporary history. The second section analyses the role in this altered situation of traditional political parties - 'traditional' here meaning territorially based organisations that work at the country level. Country-based political parties have generally failed to reorient themselves to polycentric governance, although a number of changes in their practices could enhance democracy in global politics. The third section of the chapter assesses several ways that political parties can be reorganised beyond the state: namely, through international networks of country-based political parties; through regional party formations; and through distinctly global political parties. None of these three strategies seems likely to generate major democratising impacts on globalisation in the short or medium term.

Before proceeding to detail these points it should be stressed that this discussion is more a conceptual reflection than the result of systematic empirical research. The writer's two decades of explorations of globalisation in a host of contexts across the planet may provide some grounds for informed speculations on the problems and prospects of political parties in a more global world. However, the questions and arguments set out here suggest an agenda for future research more than confirmed theses. As the limited bibliographical references in this chapter indicate, the question of political parties and the democratisation of globalisation has so far received strikingly - indeed, deplorably - little academic attention. It is to be hoped that the present chapter and the larger volume of which it forms a part may stimulate further efforts to fill this gap.

\section{Concepts and context}

To assess the actual and potential roles of political parties in the democratisation of globalisation, it is of course helpful to define terms for the purpose of the analysis at hand, as well as to describe the general context that has prompted the research question. The treatment of these complex and deeply contested conceptual and historical issues must perforce be truncated here. Readers may refer elsewhere to find further elaboration and substantiation of the arguments set out in this section (Scholte, 2005: especially Chapters 2, 3, 6, 11). 


\section{Globalisation and the shift to polycentric governance}

As the word is understood here, globalisation denotes a trend of becoming more global: the expansion of a planetary scale of social life. With globalisation people become more able - technologically, legally, linguistically, culturally, psychologically - to have direct connections with one another wherever on the earth they may be located.

Although globality in this sense of transplanetary social connectivity has sometimes figured importantly in earlier history, global relations have undergone unprecedented growth since the middle of the twentieth century. Global links between persons now arise more frequently, take more forms, transpire faster and impact more deeply than in any previous era. Indeed, contemporary history has, as never before, seen the emergence of transplanetary instantaneity (whereby certain global transmissions such as intercontinental telephone calls occur in effectively no time) and transplanetary simultaneity (whereby certain global phenomena such as satellite television broadcasts can involve people spread all over the world at the same time).

In this way globalisation entails a significant respatialisation of social relations. The global, planetary sphere becomes, in its own right, an important site of culture, ecology, economics, law, health, history and politics. Countless phenomena such as the internet, air travel, intercontinental production chains, electronic finance, climate change, criminal networks, the United Nations system, 'world music', the AIDS pandemic and women's movements cannot be geographically reduced to territorial logics. They also have a notable 'supraterritorial' quality. This is by no means to say that other (territorial) social spaces such as households, workplaces, districts, countries and regions have become any less important in contemporary society. However, these other scales of social relations are now also supplemented by, and intertwined with, major global domains. It is not possible to understand the human condition in the twenty-first century without significant attention to global dimensions.

While altering the geography of social life, globalisation also has major consequences for the mode of governance. The term 'governance' is taken here to refer to the complex of rules and regulatory institutions under which people pursue their societal interactions with each other. The vocabulary of 'governance' is here deliberately preferred to that of 'government', inasmuch as the latter word is often assumed to designate the formal, centralised, public, national, territorial apparatus of the modern state. In contrast, 'governance' encompasses the larger operations of regulation in society: non-state as well as state; private as well as public; informal as well as formal; supraterritorial as well as territorial. Thus 'governance' is understood here in the more encompassing sense that others have suggested when invoking the term 'governmentality', although the present analysis does not adopt a Foucauldian approach. 
Talk of 'governance' rather than 'government' is certainly appropriate with respect to contemporary global affairs. The regulation of transplanetary and supraterritorial matters generally involves multiple and diffuse sites. States retain a key role in the construction, implementation and evaluation of the rules that apply to global social relations, but the statist apparatus of societal regulation that prevailed in the middle of the twentieth century has given way to a more polycentric order.

For one thing, substantial elements of governance have, over recent decades, become global in scale. As logic might suggest, burgeoning global activities and issues have prompted a notable increase of rules and regulatory institutions with a global span. Some of this transplanetary governance has grown through a proliferation and expansion of suprastate agencies with multi-continental memberships and remits. Well-known examples include the United Nations (UN), the Organisation for Economic Cooperation and Development (OECD) and the WTO.

Yet global governance also entails more than what have traditionally been called 'international organisations'. Other global-scale regulation has taken a transgovernmental shape, with the development of largely informal transplanetary networks of state officials. Transgovernmental relations have addressed matters as disparate as crime, human rights, environmental regulation and various areas of trade (Slaughter, 2004). Perhaps the most visible transgovernmental apparatus is the Group of Eight (G8) process developed since the mid-1970s. Other examples include the Competition Policy Network and the Nuclear Suppliers Group.

Still further global governance has expanded in recent times through non-governmental channels. This privatisation of regulation has been manifested in regimes such as the International Accounting Standards Board (IASB, a market-based organisation created in 1973) the Forestry Stewardship Council (FSC, a civil society body formed in 1993) and the Internet Corporation for Assigned Names and Numbers (ICANN, a public-private hybrid established in 1998). Such developments demonstrate that governance of global (and for that matter any other) affairs need not by definition occur through the public sector (Cutler, Haufler and Porter, 1999; Hall and Biersteker, 2003).

Concurrently with this substantial growth of global regulation, governance has also taken more regional form during the past half-century of intense globalisation, with an unprecedented expansion of rules and regulatory institutions that apply to a group of contiguous countries. For example, 273 regional trade arrangements had been registered with the WTO as of 2003 (Cosbey et al., 2005: 2). In certain cases inter-regional governance relationships have emerged, as in the Asia-Europe Meetings (ASEM) between the EU and the so-called 'ASEAN+3' (Association of Southeast Asian Nations plus China, Japan and South Korea). Many analysts have explained this expansion of regional regulation as both a facilitator of 
and a policy response to globalisation (Hettne, Inotai and Sunkel, 1999; Hughes, Cooper and Delombaerde, forthcoming). As elaborated later in this chapter, this trend in contemporary governance opens important possibilities for political parties to achieve democratisation of globalisation through regionalisation.

The growth of suprastate (global and regional) governance has by no means rendered country-based regulation through states irrelevant in a more global world. Arguments widely heard in the early 1990s that ongoing globalisation would provoke a decline, retreat or even demise of the state have been comprehensively refuted. On the contrary, states especially the more powerful states - remain central actors in contemporary governance and indeed have ranked among the principal architects of globalisation (Weiss, 1998). In this light, the second section of this chapter affirms that political parties and party systems focused on the state retain considerable historical mileage in the early twenty-first century.

That said, states behave differently in today's more global world than they did in what could be termed the 'territorialist' politics of an earlier time. One major reorientation of state action has already been mentioned with regard to the growth and importance of transgovernmental networks. Another change has arisen with increased attention by states to global constituencies alongside domestic groups, thereby diluting the previous concentration of government on so-called 'national interests'. For example, a state today may heed pressures from the World Bank, transnational companies and/or global social movements as well as - and sometimes even more than - demands from constituents based in its formal territorial jurisdiction. Moreover, under conditions of greater globality states have acquired a number of different policy instruments, such as computer networks and (in a few cases) intercontinental missiles. In addition, although earlier theses that globalisation necessitates a contraction of the welfare state have been largely refuted, it is clear that states have significantly adjusted social policies in response to the growing global economy. And country-level governance has paralleled global governance with widespread privatisation of various regulatory tasks, as manifested inter alia in the creation of independent central banks and the spread of nongovernmental financial services authorities.

Finally, intense globalisation of the past half-century has transpired concurrently with - and in various ways contributed to - significant localisation of governance. Across the continents states have undertaken substantial devolution to sub-state regions and districts. Several states, including Brazil and Canada, have also revised their constitutions to accord greater autonomy to indigenous peoples residing in the country. Concurrently, many sub-state governments have 'gone global' by forging direct links with global capital and global governance agencies, as well as by forming their own global networks such as United Cities and Local Governments (UCLG), an association with several thousand 
members in over 100 countries. Hence political parties can also have democratic purpose in a more global world when working in sub-state government.

In sum, then, unprecedented globalisation of social life in recent history has been accompanied by substantial globalisation, regionalisation, reconfigured nationalisation and resurgent localisation of governance. To dissect the regulation of a given global issue (whether it be biodiversity loss, tourism or whatever), analysts must consider public, private and public-private mechanisms across global, macro-regional, country, microregional and local scales. Societal regulation has lost the statist character that prevailed in what has frequently been described as the modern Westphalian system. Governance is now much more than government.

The term 'polycentrism' well designates this situation of multiple interlocking nodes of regulation that are diffused across multiple scales and across public and private sectors. Others have described this situation with alternative terms, including 'cosmocracy', 'mobius-web governance', 'netocracy', 'new medievalism', 'new multilateralism' and 'plurilateralism'. Whatever label is used, however, the post-statist mode of governance requires that political parties shift their practices if they are to remain relevant and fulfil their democratising potentials in the twenty-first century.

\section{Democratic deficits in contemporary globalisation}

These democratic inputs from political parties are sorely needed in contemporary governance of global affairs. The shift from statism to polycentrism has generated enormous deficits of public participation in and public control of regulatory processes in society, particularly as they concern global issues. Shortfalls in democracy have produced some of the greatest public unease with contemporary globalisation, as witnessed most dramatically in large street protests as well as more pervasively in the casual conversations of everyday life.

As with definitions of globalisation, this chapter is not the place to undertake a lengthy excursion through the meanings of democracy. For present purposes governance is regarded as democratic when decisiontaking power lies with the people - a demos, a public, a 'community of fate' - whom the regulations in question affect. Of course, political theorists have suggested highly diverse ways to achieve democracy (deliberative, participatory, representative models and more). However, there is general agreement that, whatever its precise form, democracy prevails when the members of a public determine policies: (a) collectively, together, as a group; (b) with equivalent opportunities of involvement for all; (c) voluntarily, without coercion; (d) transparently, for all to see; and (e) responsibly, including suitable accountability mechanisms to obtain redress for errors and omissions. 
The many democratic deficits in the governance of contemporary global affairs can be conveniently summarised under four headings. The first major problem is public ignorance. Effective democracy presumes competent agents. However, most people today have far from sufficient information and analytical tools to make sense of globalisation, let alone to take well-founded decisions about its governance. This ignorance is hardly surprising, given how poorly the various sources of public education have fulfilled their task in respect of global affairs. Schools, universities, mass media, civil society associations, governance agencies and political parties have all failed to give globalisation the quantity and quality of attention required to have an adequately informed public. With poor education, public mobilisations on globalisation - if they occur at all easily have little and/or unconstructive impact.

A second leading source of democratic deficits in current governance of globalisation lies in institutional shortcomings. That is, the processes of formulating, implementing, enforcing and evaluating policies that govern global matters have failed to incorporate adequate mechanisms of public participation and public control. For example, public referenda on global policy questions have rarely occurred. Elections to representative offices have normally left global issues on the sidelines. Most public suprastate governance agencies and all private regulatory bodies concerned with global affairs have lacked a directly elected legislature. Meanwhile, national parliaments and local councils - as well as the political parties who field candidates for these offices - have rarely exercised sufficient scrutiny of government actions in global realms. Courts (on whatever scale, local to global) have systematically failed to give people adequate means of obtaining redress when policies concerning global relations cause harm. Likewise, governance agencies of all kinds have generally provided insufficient mechanisms for civil society participation in and scrutiny over their activities. Moreover, civil society associations involved in global policy processes have themselves often failed to meet adequate democratic standards in their own behaviour.

Alongside public ignorance and institutional failings, a third key type of democratic deficit in current governance of global matters relates to structural inequalities. It was earlier stressed that democracy requires equivalent opportunities for all affected persons to become involved in the policy decisions of a given polity. Yet contemporary global politics is everywhere steeped in social hierarchies. These deeply entrenched relations of dominance and subordination are manifold: by countries of the North over those of the South; by wealthy and professional classes over less skilled and unemployed workers; by modern cultures over non-rationalist life-worlds; by men over women; by whites over people of colour; by urban residents over rural inhabitants; by heterosexuals over LGTB (lesbian, gay, bisexual, transgender) orientations; by middle-aged over younger and older generations; and by able-bodied over disabled persons. 
All of these structural inequalities of opportunity have had the effect of arbitrarily skewing participation in global politics. Thus, undemocratically, certain major states have had greater weight in many global governance institutions. Indigenous peoples, women, subordinated races, sexual minorities and youth have generally found it difficult to exercise voice in the governance of global relations. Indeed, the policy directions that have prevailed in the (weakly democratic) regulation of contemporary globalisation have often sustained and sometimes even exacerbated arbitrary social hierarchies (Scholte, 2005: Chapter 10).

The marginalisation of subordinated social groups often overlaps with a fourth major source of democratic deficits in contemporary global politics, namely, an insufficient recognition of supraterritorial publics. Globalisation and the broader respatialisation of social life of which it is a part have, over the past half-century, significantly reconfigured patterns of collective identity (Scholte, 2005: Chapter 7). As a result, the nature of the demos - that is, 'the people' whose participation in and control over governance needs to be assured - has become far more complex. In territorialist times of old, 'rule by the people' simply meant rule by the national community that inhabited a given country. However, democracy in a more global world must address a plurality of publics, including many whose geography does not coincide with traditional territorial spaces.

For one thing, the proliferation and growth of transplanetary diasporas in contemporary globalisation has brought a significant supraterritorial element to many national solidarities. Prominent examples of 'global nations' include Armenians, Chilean exiles, Indians, domestic servants from the Philippines, Palestinians and Sikhs. In addition, increased globality has involved an expansion of non-territorial communities, that is, publics that have no inherent link to a particular homeland. Examples include global bonds among co-religionists, among people of the same gender or race, among those of a common class or profession, and among those of a similar sexual orientation. Furthermore, recent history has seen many persons increasingly identify themselves, at least partly, with a global humanity. This growing cosmopolitanism has been reflected inter alia in greater talk of a 'world community', 'human rights', 'global public goods' and even 'global citizenship'.

Yet the governance of global affairs has so far generally failed to accommodate this growth of supraterritorial publics. Mainstream political theory and practice still assume that the demos takes the form of a territorialnational community. An incipient global civil society has given some political space to plural and hybrid identities, but official policy processes and political party activities on global issues have tended to marginalise supraterritorial collectivities. At best, groups such as Kurds, Buddhists, women, peasants, gays and cosmopolitans have obtained some participation and accountability in the governance of global affairs indirectly, by 
using national-state-territorial channels. However, these supraterritorial publics have received little recognition in their own right with specific positions and procedures to ensure their distinctive involvement in global politics.

Taking, in sum, educational shortcomings, institutional failings, structural subordinations and under-recognition of supraterritorial publics, the governance of contemporary globalisation has had very weak democratic groundings. Emergent polycentric regulation of global affairs can in no serious way be characterised as 'rule by the people'. Understandably, as noted earlier, these democratic deficits have prompted much disquiet. Indeed, it may be asked whether current directions of globalisation are politically sustainable in the absence of significant efforts to democratise the process.

The democratisation of globalisation could be pursued through a number of channels. These avenues include: programmes of public education; measures to improve transparency and accountability of regulatory bureaucracies; reform of judicial procedures; steps to expand and upgrade civil society activities; redistribution of resources in favour of structurally disadvantaged groups; and revision of constitutions to recognise supraterritorial publics. However, the rest of this chapter looks more narrowly at how reoriented practices by political parties might bring greater democracy to global affairs. This focus on political parties reflects the theme of the present book and does not imply that other approaches to upgrading democracy in global politics are less worthy. On the contrary, effective democratisation of globalisation probably requires concurrent initiatives from multiple complementary angles, including but not limited to changes in the organisation and activities of political parties.

\section{Political parties}

As indicated at the outset of this discussion, a political party is understood here to be a formal organisation that supports candidates (that is, politicians) for elected public office. Parties may be based on any of several rationales. For example, in the tradition of many historical party formations in Western Europe, a party may be rooted in ideology and a particular vision of the good society. On the other hand, parties may also have sectoral foundations, in cases where they pursue the political interests of a given social group, be it an ethnic, regional, religious or other circle. Alternatively, a political party may find its glue in the charismatic personality of its leader(s). In other instances the raison d'etre of the party may extend no further than to serve the professional ambitions of its career politicians. Or several of these factors may figure in combination. Whatever the bonds that unite their members, however, all political parties seek to take and retain elected public office. 
A specific distinction is therefore maintained in the present analysis between a political party and a civil society association. Political parties look to occupy positions of public authority, while civil society bodies aim to shape societal rules without capturing public regulatory institutions. To be sure, grey areas may arise in the case of fringe political parties (such as most ultra-nationalist formations) that have little or no prospect of winning elections. At the same time certain civil society associations (for example, a number of trade unions) have maintained close affiliations with political parties. Thus, as ever, no definition is crystal clear. However, the broad distinction between political parties and civil society is sustainable. The differentiation is also analytically useful in an investigation of democracy, inasmuch as political parties give priority to strategies of indirect and representative democracy, whereas civil society associations tend to pursue more deliberative and directly participatory routes to popular sovereignty.

So now to the specific concern at hand: what can political parties do to effect more participation and control by the demos in the construction of rules for the more global world of the twenty-first century? The rest of this chapter considers what political parties might contribute, both through traditional territorial-national organisations and through international, regional and global frameworks.

\section{Country-based parties in a more global world}

As noted briefly in the preceding survey of democratic deficits in contemporary globalisation, traditional territorial political parties (that is, those constructed around a country unit in order to pursue office in the national and local governments of that land) have so far failed to generate much public participation in and public control over the governance of global affairs. The following paragraphs identify five main ways that countrybased political parties have fallen short in this regard and suggest corrective steps under each of these headings that could increase their contributions to a more global world. The third section of this chapter then goes on to argue that - however far country-based bodies might raise their inputs to global democracy - political parties must, in the current circumstances of polycentric governance, also organise beyond country-statenation units far more than they have done to date.

\section{Educating publics}

As mentioned before, traditional territorial parties have - along with other actors in contemporary politics such as schools, the mass media and civil society associations - generally failed to make publics sufficiently conscious of expanding global social spaces and the ways that global issues are and 
are not governed. Questions of global policy have rarely figured prominently - and often not at all - in party conferences, rallies and workshops. Likewise, global affairs have usually featured marginally, if at all, in party research and training programmes, in the selection and promotion of candidates, in a party's press conferences and other public communications, and in campaign manifestos and debates. True, certain parties have raised public understanding of certain global problems, for example, in the case of Green parties with respect to planetary ecological challenges. For the most part, however, political parties have neglected their many opportunities for public education on global matters.

Indeed, this consistent failure to address global issues has arguably contributed to a widespread loss of stature for traditional political parties in the public eye. Concurrently with accelerated globalisation in recent decades, most established liberal democratic states have experienced significant reductions in party memberships and voter turnouts. Many factors have prompted this decline, of course, but among them are public perceptions that established party systems have lost relevance in addressing the priority issues of the day. In turn, a good part of that apparent loss of relevance arguably lies in the neglect, especially by the large mainstream political parties, substantially to engage the global realities of contemporary society.

This diagnosis of the problem evokes its own prescription, namely, that traditional territorial political parties should give greater attention to global affairs. Parties would thereby contribute more to public awareness of these vital issues and at the same time reaffirm their relevance for the twentyfirst century. The fact that traditional political parties operate on a country-state-nation scale does not mean that they must restrict their policy vision to territorially bounded issues in their land of operation. On the contrary, parties arguably have a societal obligation proactively to reshape the agenda of public debate so that it catches up with the more global world that has emerged over the past half-century. Indeed, for parties to perpetuate (inadvertently or otherwise) territorialist and statist myths is highly damaging given the challenges that globalisation poses inter alia for material welfare, ecological integrity, the rule of law, cultural identities and social cohesion.

Country-based parties could take a number of specific measures to become more effective agents of public education on global affairs. For example, party meetings, publicity materials and electoral campaigns could more regularly and prominently discuss global policy issues such as climate change, governing the internet and global taxes to finance development. In addition, competence to handle global issues could be made a significant consideration when parties select their candidates. Political parties could also commit more resources to research and training that would enhance the capacities of politicians and their staffs to address questions 
related to, for instance, global migration flows, global disease control, and global arms trade. More globally educated candidates and party workers would in turn, through the wider political process, foster more globally educated (and thereby more democratically empowered) publics.

\section{Occupying state office}

As well as by educating publics, country-based political parties can fulfil a democratising function in today's more global world by doing what they have always done, namely, gaining and holding executive power in national and local governments. As indicated earlier, globalisation has by no means sidelined territorial governments. On the contrary, states remain key actors in the regulation of global relations. Even district councils in small countries face decisions concerning, for example, contracts with global companies and implementation of global resolutions on the environment. Hence control of national and local governments gives political parties major opportunities to shape globalisation in line with the popular will.

To date, however, political parties have generally underplayed these possibilities to democratise global affairs. For one thing, as already stressed, parties have mostly failed to promote public understanding of and deliberations about global policy issues, so that there is little well-formed popular will upon which a democratic state could act. Lacking awareness of global relations and their governance, publics rarely press politicians holding public office to act on the problems.

Nor have elected representatives in national and local government shown themselves particularly inclined to rise to global challenges. Indeed, politicians have all too often depicted globalisation as an omnipotent external force over which the state can exercise no control. In this vein, countless ministers have blamed various ills of their country on global competition, global technologies, global epidemics and global institutions such as the IMF.

Yet politicians hereby underestimate their potential influence and abdicate their democratic responsibility. To be sure, a number of global circumstances have constrained the range of choices available to states. Sovereignty in the old Westphalian sense of a state's claim to total authority over its realm is unavailable in the more global world of the twentyfirst century. However, it is quite another thing to say that increased global connectivity has rendered governments prostrate. After all, states (especially stronger states) have considerable leeway in deciding whether, when and under what terms to accede to global regulatory regimes. Likewise, most states - other than the weaker ones - have notable scope in determining economic, social and environmental policies vis-à-vis global capital. Moreover, however global the world may have become, states 
today jealously retain their near-monopoly positions in governing migration and military affairs, yielding only marginal roles to suprastate and private regulatory mechanisms. Also, globalisation has given states (especially the major states) various new tools and enhanced opportunities for influence with, for instance, electronic mass media, global currencies and even satellite surveillance.

Given this continued importance, the state remains a prize well worth contesting in a more global world. By winning national and local government office, traditional territorial political parties can substantially mould the formulation and execution of a state's policies on global issues. If the victorious parties are genuinely democratic forces, then the governments that they lead can steer globalisation in popularly preferred directions. Again, however, to achieve this democratic purpose country-based political parties need to give global issues due priority and to equip their staffs and memberships with competence to handle global agendas.

\section{Scrutinising state policies on global affairs}

Yet political parties do not have to occupy national and local executive office in order to democratise state policies on globalisation. In addition, parties in opposition - as well as critical voices within ruling parties can play the role of democratic watchdog, scrutinising whether or not the government of the day is reflecting the popular will in its handling of global issues. In this way country-based political parties can contribute to democratic accountability in globalisation.

Regrettably, few traditional political parties have done much to exploit these democratising possibilities. As ever, to be sure, certain exceptions exist. For instance, a number of national politicians and parliaments have in recent years undertaken closer examination of their government's involvement in the Bretton Woods institutions (Halifax Initiative, 2004). However, this (modest) example stands out as a deviation from the norm of neglect. For instance, no country-based parties and their representatives in parliaments have performed systematic oversight of the important transgovernmental networks described earlier. Likewise, state bureaucracies have adopted most of their international commitments regarding global matters without reference to legislatures and the political parties that populate them.

Clearly parties could do much more in this area. Alongside (and sometimes in collaboration with) civil society associations and the mass media, political parties could be leading agents of public scrutiny over a state's involvement in global affairs. For example, party organisations and politicians could sponsor many more critical studies of a state's policies on, say, global environmental matters, global human rights questions or global debt problems. Party representatives in legislative bodies could use 
committee hearings and plenary debates to push for improved government action on given global matters. Likewise, opposition parties could make the incumbent government's record on governing global aspects of, say, trade or health a headline issue in election campaigns.

\section{Engaging governance beyond the state}

Important though the measures just discussed may be, traditional political parties must not restrict their quest for public participation and public accountability in global governance to the state alone. Like other political actors in the twenty-first century, parties need to abandon outdated statist assumptions and reorient their practices to the emergent polycentric mode of governance. That means actively engaging the state, to be sure, but also other regulatory bodies. To remain effective in a more global world, country-based political parties must in addition attend to a host of suprastate and non-state governance mechanisms.

Yet in this area, too, traditional political parties have, to date, generally failed to deliver. True, as indicated in the next section, certain national parliamentarians have built connections with certain global regulatory agencies such as the World Bank and the WTO, but they have generally done so on their personal initiative. However, country-based political parties have not, as party organisations, pursued a policy of systematically engaging with suprastate institutions, let alone private regimes of global governance. A potentially important channel for conveying democratic voice to regulatory bodies beyond the state has therefore gone unutilised. Moreover, the lack of contact with suprastate and private regulatory agencies has exacerbated the parties' ignorance of governance outside the state. Conversely, too, the absence of links with parties has contributed to often poor understanding on the part of global bureaucracies such as the IMF about political circumstances in the various member countries. Romania is a good example of repeated IMF failure, which contrasts with Lithuania where IMF contact with the political opposition proved helpful when the party in power changed.

The failure of country-based political parties to engage governance institutions beyond the state becomes all the more striking when compared with the record of civil society associations in this respect. Countless business forums, community groups, faith-based movements, labour unions, NGOs and think tanks have developed substantive relationships with the various multilateral development banks, UN organs, the WTO, the OECD, and even a few private regulatory bodies such as ICANN. In response to these initiatives, many suprastate governance institutions have set up civil society liaison bureaus, developed systematic procedures for civil society consultation, and issued staff guides for relations with civil society associations. These official mechanisms remain inadequate in many respects, but at least they exist in rudimentary form. 
In marked contrast, global regulatory bodies have constructed nothing of this sort for relations with political parties. This is principally because, unlike civil society organisations, parties have placed the suprastate agencies under no concerted pressure to engage. It seems telling that, as of 2003, IMF headquarters had devoted half a dozen staff to civil society matters, while only one junior official had a half-time responsibility for parliamentary liaison across the entire world.

In short, if country-based political parties are to reaffirm their promise as major democratic forces in a more global world, they really must catch up with the realities of polycentric governance. Their traditional statist orientations and practices are not enough for the twenty-first century and must be supplemented with systematic efforts to bring public voice and public accountability to the many suprastate and non-state sites of regulation in contemporary governance of global affairs.

\section{Promoting global equality}

Yet however educated the publics and however improved the institutional processes, greater democracy will not prevail in the more global world of the twenty-first century unless the previously described structural inequalities are also addressed. If veritable 'rule by the people' is to hold sway in global politics, then all social categories (countries, classes, cultures, genders, races, urban/rural sectors, sexualities, age groups and so on) must have equivalent possibilities of involvement in the governance of transplanetary affairs. Partly, that requires changes in institutional processes (such as voting systems and consultation procedures) to ensure that various structurally subordinated circles obtain due voice in the regulation of globalisation. Beyond institutional changes, greater political equality also requires greater economic equality, which in turn necessitates a major global-scale redistribution of resources.

In this aspect of the democratisation of globalisation, too, traditional territorial political parties have generally done little. To be sure, a host of socialist and communist parties have historically championed the cause of underclasses. In more recent decades many parties have proactively sought to increase the involvement of women and racial minorities. However, despite some internationalist rhetoric, such initiatives by political parties have in practice focused on reducing inequalities within the country at hand rather than in a larger global polity. As for progressive global redistribution, political parties in Northern countries have (apart from a handful of endorsements of the proposed Tobin tax on currency transactions) rarely gone beyond advocacy of modest resource transfers via international development assistance. Meanwhile political parties in Southern countries have generally lacked the means to pursue concerted campaigns for more ambitious global redistribution. 
Once again the diagnosis of failings yields a clear corrective prescription: in order to advance democracy in global affairs, political parties should promote institutional changes and resource redistributions in the direction of greater global social equality. However, this remedy is easier identified than implemented. In particular, so long as traditional political parties maintain a territorial organisation and principally serve countrybased constituencies, it is hard to see how global equality could come to rank among their priority concerns.

\section{Recognising peoples beyond the territorial nation}

Likewise, the territorial orientation of traditional political parties forms a structural impediment to progress on the fourth type of democratic deficit mentioned earlier, that is, the need to provide participation and accountability for a variety of publics, including those that do not take a territorial-national form. Traditional political parties assume that 'the people' in 'rule by the people' is the national community that inhabits the country at hand. Territorial parties cater to supraterritorial types of demos (such as those based on world religions, global class solidarities, or humanity as a whole) only secondarily, if at all.

Certain exceptions to this overall neglect are found in respect of diasporas. For instance, a number of country-based political parties in Africa have received significant funding from co-nationals resident abroad. Ghana has even known an 'Every Ghanaian Living Everywhere Party' (EGLE) that won one parliamentary seat in the 1993 elections. Many states now allow those of their citizens based outside the country to vote in national elections.

However, traditional parties have done little to attend to supraterritorial publics of a non-national kind. To obtain democratic voice these 'peoples' have tended to desert political parties and turn instead to transnational social movements such as Vía Campesina (for global peasant solidarity), the International Lesbian and Gay Association and the World March of Women. Unfortunately these global civil society actors have developed few links with political parties, connections that could make parties more sensitive to plural and hybrid identities in contemporary politics. Indeed, the World Social Forum, a major initiative to create a global public space for a host of civil society movements, has in its Charter of Principles (point 9) specifically excluded delegates from political parties.

In sum, while traditional political parties certainly do not stand in contradiction to democracy in global politics, they have on the whole thus far failed to realise their potential as forces for bringing greater 'rule by the people' to transplanetary affairs. As indicated above, countrybased parties offer, in principle, some of the most promising and practicable possibilities for a democratisation of globalisation. The main difficulty 
is getting established political parties and party systems to discard old assumptions about the nature of governance and to address the new realities of a more global world.

\section{Beyond traditional political parties}

Yet no matter how far traditional political parties might pursue the democratisation of globalisation, their efforts can never be enough by themselves. However much country-based parties might change their practices, by definition they have a primarily territorial orientation that inhibits them from completely adequately handling global issues. Invariably, traditional parties mainly operate in a country sphere (to the relative neglect of other realms); they mainly engage the corresponding state apparatus (to the relative neglect of other sites of regulation); and they mainly relate to the corresponding national demos (to the relative neglect of other peoples).

In order to address more fully global spaces, governance beyond the state and publics beyond the territorial nation, political parties also need to organise themselves on more than country-state-nation lines. The rest of this chapter considers three steps towards such a broader orientation, namely, the development of international, regional and global party organisations. Overall it is concluded that these alternative party forms offer important possibilities for democratising global politics but limited immediate impacts. For the time being civil society activities beyond the country-state-nation hold more promise for advancing global democracy than international, regional and global parties.

\section{International party networks}

One readily available path to develop more globally oriented political parties is to build international links between established country-based organisations. Such networks allow traditional parties to exchange views, pool expertise and co-ordinate actions with partners across the planet on global issues in particular. International collaboration among parties can, furthermore, have democratising effects if it promotes more public awareness of global affairs, more opportunities for public participation and accountability in global policy-making, and greater equality and identity recognition in global politics.

Like many global activities, the origins of international party organisations can be traced to the late nineteenth century. The International Working Men's Association (First International) operated across Europe and North America from 1864 to 1876. The Second International linked country-based socialist and labour parties from 1889 to 1916, being succeeded in the 1920s by several rival bodies. The Third or Communist International (Comintern) institutionalised a world movement of territorial 
communist parties from 1919 to 1943, followed briefly by the Communist Information Bureau (Cominform) from 1947 to 1956.

Several international associations of country-based political parties are active today. Following the footsteps of the Second International and its interwar successors, the London-based Socialist International (SI) currently involves 148 country-based parties. The Fourth International, founded by Trotskyists in 1938, persists on a smaller scale and without an official secretariat. The Liberal International (LI), established in 1947 and also maintaining headquarters in London, includes full and observer member organisations from 54 countries. The Oslo-based International Democrat Union (IDU), launched in 1983, currently groups 47 country-based parties with conservative and Christian Democrat orientations. The youngest international party association, the Global Green Network, was formally created in 2001, although regular intercontinental communications among country-based ecological parties date from the early 1990s.

The various party internationals have regularly considered matters of global public policy. For example, the SI has supported committees, campaigns and working groups concerning inter alia poor country debt problems, migration, the Bretton Woods institutions, the Kyoto Protocol to the United Nations Framework Convention on Climate Change, and the WTO. The Fourth International has treated contemporary capitalism and workers' struggles as distinctly global issues. The LI has repeatedly addressed 'the challenges of globalisation'. The Global Greens reveal a transplanetary orientation in their very name as well as in specific attention accorded to matters such as climate change and nuclear proliferation.

In addition, other international networking among members of countrybased political parties has occurred through meetings of national legislators. In this vein the Geneva-based Inter-Parliamentary Union (IPU) has operated since 1889. The London-based Commonwealth Parliamentary Association (CPA), dating from 1911, now links some 170 state and sub-state legislatures from 53 countries. Both bodies have handled a number of global issues, including disarmament, financing for development, HIV/AIDS and trade. In addition, Parliamentarians for Global Action (PGA), an association involving over 1,300 representatives from 114 national legislatures, has worked with various UN agencies since the late 1970s.

Several other international networks of country-based parliamentarians have focused on specific global problems. In this vein the Global Legislators Organisation for a Balanced Environment (GLOBE), launched in 1989, now groups representatives from over 100 national parliaments. Since 2000 a Parliamentary Network on the World Bank (PNoWB) has involved several hundred elected representatives from around 50 countries. Beginning in 2003 the IPU and the EP have jointly convened an annual Parliamentary Conference on the WTO with legislators from around 80 countries. 
Yet the extent of this international co-operation among country-based parties must not be exaggerated. After decades of operations these international associations have made only very modest impacts on global politics. Relatively few members, politicians and staff of political parties have devoted substantial time and energy to these networks. All of the party internationals have remained poorly resourced, with tiny staffs and budgets. Even the oldest and largest of these bodies, the SI, currently survives on an annual budget of only $£ 1$ million.

In short, a much bigger scale of international networking among countrybased parties would be required in order to advance a notable democratisation of globalisation through these channels. The party internationals would need to do much more than has occurred so far to raise public awareness of globalisation and its governance, to engage suprastate and private regulatory institutions, to combat global inequalities, and to provide platforms for supraterritorial as well as territorial publics. In principle the possibilities of international networking among traditional political parties are substantial, but in practice the results to date have been negligible.

\section{Regional parties}

One step towards greater global democracy through political parties could be to move away from country-based organisations. After all, while international party networks may operate globally, their constituent elements still derive from - and work primarily within - a country-state-nation framework. However, political parties could also be organised in relation to other kinds of geographical units, including regional spaces in particular. Indeed, several of the party internationals also organise their members in regional sub-groupings.

As noted earlier in this chapter, regionalisation is a major contemporary trend alongside globalisation in contemporary history. Considerable regulation of global flows (in terms of communications, finance, investment, trade and so on) has developed over recent decades through regional governance apparatuses such as the EU and the Southern Common Market (MERCOSUR). Many advocates of regionalism have argued that such frameworks offer major - perhaps even the greatest - opportunities to harness global flows in the public interest. From this perspective regionalisation would be a primary strategy for the democratisation of globalisation.

Thus far two regional governance projects have acquired directly elected parliamentary bodies. Representatives of the European Parliament of the EU (now numbering 732 in total) have been directly elected every five years since 1979. Voters in the six member countries of the Central American Common Market select 132 representatives to the Central American Parliament, which has convened in Guatemala City since 1991. 
Not surprisingly, the emergence of directly elected regional assemblies has encouraged the development of regionally organised political parties to contest the seats. In the EU, for example, a distinctly regional European People's Party (EPP) has operated since 1976 and the Party of European Socialists (PES) was formed in 1992. The European Free Alliance (EFA) was founded in 2004 to represent stateless nations across the region. Other Members of the European Parliament (MEPs) are organised in looser coalitions of national parties. So far the Central American Parliament has not acquired distinctly regional political parties, although the deputies have formed three main international blocs.

Meanwhile a number of other regional governance frameworks have gained indirectly elected representative bodies with members who are appointed from the national legislatures of the member states. Examples include the Parliamentary Assembly of the Council of Europe (inaugurated in 1949), the Andean Parliament of the Andean Community (1979), the Consultative Assembly of the Arab Maghreb Union (1989), the Parliamentary Forum of the Southern African Development Community (1996), the East African Legislative Assembly of the East African Community (2001), the Parliament of the Economic Community of West African States (2002) and the Pan-African Parliament of the African Union (2004). In addition, a stand-alone Latin American Parliament has, since 1987, linked legislatures of that region, but without constituting part of a larger regional governance apparatus. Thus far these indirectly elected regional bodies have not called forth distinctly regional party organisations, although such a development might be anticipated in the course of further regionalisation in the future.

However, neither the existing regional political parties nor the regional parliaments have as yet realised significant democratising impacts on globalisation. At best they have occasionally brought global issues to public attention. Still more rarely they have scrutinised a regional body's handling of globalisation (such as the European Commission's policies in WTO talks). Like the secretariats of international party networks, the bureaus of regional political parties have had very few resources at their disposal. Moreover, the regional party organisations have generally maintained at best incidental and loose links with individual members and constituency branches, thereby generating little democratic participation and accountability for the grass roots. Indeed, the vast majority of EU citizens are probably unaware even of the existence of the EPP, PES and EFA.

In sum, then, the proposition to further a democratisation of global politics through regional parties and party systems has an appealing underlying logic in some respects, but has as yet delivered little substance. Fuller realisation of this potential would require larger and more influential regional governance instruments, stronger and directly elected regional parliamentary assemblies, and well-resourced regional party organisations 
that maintained close connections with citizens. Such institutions would seem unlikely to develop very quickly, particularly outside Europe.

\section{Global political parties}

If effective regional political parties are at best a project for the medium term, global political parties as instruments for transplanetary democracy are today an even more remote prospect. In contrast to international party networks, which assemble country-based organisations that strive to hold state power, distinctly global political parties would promote candidates for elected global governance offices. Although this idea has some support (cf. Patomäki and Ulvila, 2006), it hardly seems a practicable option for the time being.

To be sure, contemporary globalisation has created pressing needs for much more regulation with a transplanetary scope, and the major expansion of global-scale governance witnessed over the past half-century looks set to continue into the future. Demands for democratic participation in and public accountability of global regulatory institutions will carry on mounting, the more so if - as seems quite possible in the years to come - global taxes begin to generate resources of their own directly for transplanetary governance agencies. The stage would then be set for cries of 'no taxation without representation' at the global level.

Yet thus far no global-scale regulatory agency, public or private, has shown any sign of including a directly elected representative arm. No UN Legislature, IMF Assembly, OECD Congress, or ICANN Parliament is in prospect. Hence the raison d'être for distinctly global political parties is - and looks to remain - decidedly absent. Such parties will not form if they have no seats to contest. The democratisation of global-scale governance mechanisms must therefore be sought through channels other than a transplanetary party system.

In any case the construction of elected representative bodies attached to global-scale governance agencies raises highly problematic issues. For example, how would constituencies within a global arena be drawn? On country, regional and/or supraterritorial lines? What electoral formula would be used for global assemblies? One person, one vote, or some kind of weighting (and if so which one)? How would transplanetary ballots be conducted and monitored? What regime of campaign financing would apply to global political parties?

Moreover, beyond these practical difficulties for global representative democracy through global political parties lie deeper cultural problems. One such systemic challenge is constructing a sufficiently strong general ethos of global citizenship, in which a large proportion of humanity would frame its sense of political rights and duties substantially in terms of a transplanetary polity and therefore find it meaningful to engage in 
global party politics. After all, country-based party systems did not become effective mechanisms of participation and accountability until major proportions of territorial populations directed significant political commitments to the nation-state. Regional political parties have limited prospects as engines of global democratisation so long as regional populations have developed only a shallow, if any, sense of regional citizenship, as evidenced in relatively and absolutely low voter turnouts to elections of the EP (see Chapter 5). Although global citizenship is arguably incipient and growing in contemporary politics, it is at this point in time even further from being a major force than regional citizenship.

Finally, the construction of global political parties would face huge challenges of navigating cultural diversity. How could one devise a single coherent transplanetary regime of parties and elected offices that equitably accommodated the wide variety of political cultures across the planet? Even on the smaller scale of territorial states, party systems have often marginalised and excluded specific populations such as many indigenous peoples for whom this modern model of democracy is culturally alien. Indeed, in some cases whole countries - as in many parts of Africa and Asia - have struggled to construct working party systems. Great care would need to be taken to construct global political parties that delivered veritable participation and accountability to all and not just to a modernist elite. However, the necessary tools of intercultural communication and negotiation are not yet available for effective 'pluriversal' politics of this kind.

In sum, then, contemporary governance of global affairs has major needs for supraterritorial frameworks of democratic mobilisation, but the situation is not ripe for global political parties to fill this niche. For the time being global civil society associations hold the greater promise in this regard.

\section{Conclusion}

This chapter has reflected on the role of political parties in promoting democratic governance of global affairs. Contemporary rapid growth of transplanetary and supraterritorial social connectivity has significantly reshaped the contours of governance and created corresponding needs to recast democratic practices. Political parties continue to offer important democratic potential in the more global world of the twenty-first century, but they must adjust to the changes in order to realise this promise.

Many contributions to a democratisation of globalisation can come from traditional territorial political parties. Country-based parties can advance global democracy: by educating publics; by occupying state office; by scrutinising state policies; by engaging governance beyond the state; by promoting global equality; and by recognising peoples other than 


\section{Jan Aart Scholte}

territorial nations. In short, traditional party systems can be relevant to public participation and public accountability in global politics if they suitably reorient their conceptions, priorities and practices.

At the same time, as much as possible should be done to promote new types of party formations beyond country-state-nation units. As stressed above, the effectiveness of international, regional and global party organisations as agents of democratic globalisation will remain limited so long as they lack the resources and the popular bases to generate veritable public participation and public accountability on any significant scale. Nevertheless, international and regional party constructions in particular hold potentials that warrant pursuit.

Yet however much might be achieved towards global democracy through political parties, it is clear that they can fill only part of the picture, particularly so long as suprastate and private regulatory bodies lack elected representative offices. Even then democratic global politics would require, among other things, a fully operative global human rights regime, more globally oriented public education and mass media, and a vibrant global civil society. Party systems are no more a panacea for future global democracy than for past territorial democracy. 


\title{
4 Examining international political party aid
}

\author{
Thomas Carothers
}

International aid aimed at strengthening political parties in countries attempting democratisation has been growing in size, diversity and geographical reach during the past decade and a half. This expansion is one part of the broader growth of aid for democracy during these years. Political party aid remains a relatively small part of the overall domain of democracy assistance, but it clearly now has a place as one of the main areas of attention, alongside assistance to promote free and fair elections, civil society development, the rule of law and democratic governance.

This recent expansion of political party aid has occurred in two phases. The first occurred in the 1990s and was primarily fuelled by the opening up of Central and Eastern Europe to political party assistance (and democracy aid generally). Both American and European parties, party foundations and party institutes saw in post-1989 Central and Eastern Europe a compelling opportunity for extending their work. The US party institutes hurried in the years immediately after the fall of the Berlin Wall to set up programmes to support the new pro-democratic parties emerging in the region, out of concern that without external assistance these parties might be pushed off the stage by adaptive former communists building successor parties out of the financial, administrative, and human resources of the old communist parties. European parties and party aid organisations also moved into the region, slowly at first, then on a large scale across the decade, attracted by the sense of rediscovered political solidarity with a part of Europe long cut off from the West, ideological similarities of many post-communist parties to Western European parties, and the relative ease of working in a closely neighbouring region. Many new European party foundations were established in the 1990s, in France, Sweden, the Netherlands, and elsewhere, to respond to this opportunity and to expand European party aid more generally. Both US and European party organisations also began working in sub-Saharan Africa in these years, especially in southern Africa, as transitions to multipartyism in many African countries led to a multiplication of new parties and many opportunities for new partnerships and co-operation. 
The second phase of expansion occurred after the 1990s. Party aid has increased significantly in Latin America (a region where the German Stiftungen had been active in the 1970s and 1980s but from which they retreated considerably in terms of party aid in the 1990s) and continued to spread in Africa. In Latin America, for example, significant party programmes have been carried out in recent years in Bolivia, Venezuela, Peru, Nicaragua, El Salvador, Guatemala and elsewhere. And as part of the greater Western involvement in democracy promotion in the Middle East in the past five years, party aid programmes are multiplying there, too. This phase of expansion has been marked by the entry of another wave of new party aid actors. These include, for the first time, various multilateral organisations, such as the United Nations Development Programme, the Organization of American States, the Organization for Security and Co-operation in Europe and the International Institute for Democracy and Electoral Assistance. Northern European governments have also become more active in this area, with the establishment of the Netherlands Institute for Multiparty Democracy, the Norwegian Centre for Democracy and increased support through the Swedish International Development Co-operation Agency for party work. The impetus for the most recent expansion of party aid has primarily been the widespread perception that many attempted democratic transitions are running into difficulty and that problematic political parties are one of the main institutional weaknesses contributing to those troubled transitions. The rapid increase of party aid in Latin America, for example, is tied to the sharp sense among regional political leaders and experts that political parties in the region are in a state of crisis.

Like almost all areas of democracy assistance, political party aid has expanded more rapidly in scope and level of activity than in the elaboration of well-grounded analysis and evaluation of the basic methods, value and validity of such work. And the gap is only slowly starting to be closed. In particular, five key questions about such assistance remain unsettled in the view of many people within the development community and the countries on the receiving end of such aid:

1 Is the goal of international political party assistance clear and coherent?

2 Are the methods of such assistance well designed and effective?

3 How is party aid evolving?

4 Is party aid a form of partisan political interference in other countries' affairs?

5 Does it have significant positive impact?

Although definitive answers to these questions are not yet available, recent research that this writer has carried out looking at party aid on a crossregional basis provides some preliminary insights. ${ }^{1}$ 


\section{A mythic model?}

Organisations that engage in political party assistance often describe the goal of their work in very general terms, saying they seek to help build stronger or more capable parties in the places where they work. Observing their programmes on the ground, however, one can see that in fact the general concept of stronger or more capable parties has a fairly specific, clear meaning in practice. Stated briefly, Western party aid seeks to help build parties that are internally democratic, rationally and competent managed in a non-personalistic manner, effective at campaigning, rooted in society, law-abiding, financially transparent, ideologically defined, strongly inclusive of women and youth, good at media relations, and focused on grass-roots membership development and citizen outreach in between elections.

These priorities for party development grow out of a generalised model of parties in established democracies. In fact this model could be described as mythic or idealised. All areas of democracy aid suffer to some degree from a gap between idealised models that aid providers hold out to aid recipients - whether it is of efficient, non-corrupt legislatures, swift, highly competent and politically disinterested judiciaries, vigorous, diverse and independent media, non-partisan, self-sustaining, powerful NGO sectors, or engaged, well-informed citizenries - and the realities of most such institutions or sectors in established democracies. Yet this problem is particularly acute when it comes to political party work. Perhaps a few parties in the established democracies have the main characteristics that party aid seeks to produce in parties in new or struggling democracies. That is to say, perhaps a few parties are internally democratic, managed in a rational, non-personalistic fashion, highly inclusive of women, ideologically coherent, committed to issue-based, grass-roots campaigning and so forth. Many, or most, however, fall well short of this ideal.

The problem of a gap between prescriptions dispensed abroad and realities at home hits US political party aid especially hard. The US Republican and Democratic parties - being organisations with no formal membership rolls, weak central structures and a dominant focus on their role as organisers of candidate primaries - substantially do not resemble what most Western political scientists consider as the 'normal' model of a political party, which is largely based on a European, or perhaps even more specifically Northern European model (with the post-war German parties archetypes of strong parties). Thus it is striking to see the US political party institutes (the IRI and the NDI) going to other countries to push for the development of political parties of a type that actually does not exist in the United States, and doing so as though such parties are natural and necessary for the consolidation of democracy.

Western party aid appears to be based on a model of parties that is not just unusually successful and well balanced compared to reality but 


\section{Thomas Carothers}

that is also somewhat dislocated in time. Many of the organisational features that party aid programmes emphasise hark back to an earlier age, sometimes in the first half of the twentieth century, before the rise in established democracies of television-driven, image-oriented campaigning, the diminution of direct links between parties and voters, the blurring and fading of traditional ideological orientations, the widespread public cynicism about politics and the rise of heightened individualism, with its negative consequences for the tendency of people to want to invest time in or feel attached to broad-based socio-political organisations. Some party aid practitioners seem to believe that fledgling parties in new or struggling democracies can first develop as parties did in the days of traditional politics in the established democracies (though fully inclusive of women in accordance with the most contemporary Western values) and then at some later stage deal with the all pressures and exigencies of socio-political post-modernism. In fact, however, new or struggling democracies do not have the luxury of passing through the various slow, evolutionary stages of nineteenth and twentieth century European political development. They are pushed both by their own citizens and the Western donors to move quickly ahead on all elements of democratisation at the same time, especially elections. For many parties this means plunging directly into the age of media-saturated, hyper-individualistic politics without a century or so of gradual, grass-roots-oriented development in which elite parties grow into or give way to mass-based parties that over time then evolve into catch-all parties or beyond.

\section{A problematic standard approach}

Party aid organisations not only tend to operate from a notably uniform idea of what constitutes a good political party, they pursue this goal with a fairly consistent set of methods. These methods are rooted in the dominant 'institutional modelling' approach of democracy aid that Western democracy promoters employ in most domains of their work: party aid providers start with a conception of what a good party is and then try to provide training and other forms of technical assistance to help recipient parties become like the good party model. Training is by far the most common method - party aid is a sea of workshops, seminars and round tables sponsored by party aid organisations, at which representatives of 'target' or recipient parties receive exposure to a wide range of methods and techniques of party-building and election campaigning. The archetypical party aid event is a two- or three-day training workshop on party building led by a few experts from a Western capital who fly in to instruct several dozen party cadres then fly out again once the workshop is over.

In addition to training, party aid providers also often offer exchange visits and study tours. The study tours usually involve a group of representatives of one or several parties spending a week or two in the 
aid-providing country to meet people in counterpart parties and government agencies to learn at first hand about the workings of parties and democracy. Exchanges also go in the other direction, with party delegations travelling from aid-providing countries to visit counterparts in aid-receiving countries.

Party aid also frequently includes extensive advice and counsel provided by representatives of Western party foundations or institutes to party leaders or activists in recipient countries. This advice and counsel may cover all sorts of issues relating to the recipient party's operations Western party aid representatives might cajole a party leader to delegate power to his subordinates or form a coalition with another party, urge a party's executive committee to adopt a new method of candidate selection, give advice to a senior party official about how to structure a new executive committee in the party, or tell a local party branch leader how to strengthen his branch.

Different party organisations combine these various methods into different approaches. Some, particularly the German Stiftungen, which usually have a long-term field presence in the countries where they work, conceive of their party aid role as that of a resource centre for the party or parties they seek to support. The head of their local office offers a flexible mix of assistance - occasional training or discussion workshops and seminars, study tours and exchange visits, books and others materials, and frequent advice. Others, especially the US party institutes, emphasise training, defining their role and their goals primarily as helping parties achieve certain capabilities and organisational characteristics via a set of training activities, combined with some strategic advice and guidance. And still others, including most of the European party foundations (or international outreach offices of parties) that operate without field offices in other countries, primarily utilise exchange visits. Through a series of visits or study tours in both directions between the aid-provider's and the aid-recipient's capitals, a network of personal relationships and opportunities for information transfer is established between the party offering aid and the counterpart party in a newly democratising country. The relationship advances as the exchanges proceed with a wider range of people on the parties on both sides taking part, friendships being established and trust developing.

The basic approach of party aid - institutional modelling using a common 'toolbox' of familiar methods of knowledge transfer - has a clear advantage. It allows aid providers to go to almost any other country, no matter how unfamiliar the political life and how complex the underlying socio-political structures, and settle quickly on a party-strengthening programme that at least has a clear sense of both purpose and method. And its consistency across highly varied contexts allows for a certain ease and economy of execution. At the same time, however, the basic approach 


\section{Thomas Carothers}

has some serious weaknesses. When interviewed, participants in party aid highlight certain problematic features of much party aid. Above all, they dislike what they view as the frequent use of pre-set, standardised designs not well adapted to their particular context and mechanistic methods of implementation.

Training programmes come in for steady criticism. Indeed the high level of 'workshop fatigue' among persons on the receiving end of political party training programmes is very striking. The criticisms about training include the following:

1 Training workshops are often short, one-off events with no real followup.

2 Aid providers allow party leaders to choose the wrong kind of participants for training events, that is, either personal cronies of the party leader, who have little interest in the training, or marginal persons who will not be able to effect change in the party.

3 The trainers are often 'fly-in' experts who lack substantial knowledge of the local scene and teach from a set script based on political practices in their own country.

4 The topics covered in the workshops are often chosen by the aid providers.

Shortcomings of using exchange relations as a method of party aid are also quite manifest. Study tours and exchange visits are good for building goodwill and personal ties between parties, but they are generally a poor method for supporting party reform. If a study tour is carefully designed, the participants rigorously chosen and the tour closely integrated with follow-up training activities that will provide reinforcement, it can be useful. Most study tours, however, do not have these characteristics and serve little purpose beyond relationship-building. Visits in the other direction by a delegation of party officials or parliamentarians from the aid-providing country to a counterpart party on the receiving end also contribute to some friendship building and solidarity but rarely have much more substance. And with respect to the advice and counsel that party aid representatives provide to counterparts, research interviews with both sides reveal a substantial gap between the providers and the recipients of such advice and counsel regarding the weight and value of such interventions.

The chronic weaknesses of the standard method are, generally speaking, recognisable symptoms of technical assistance that is supply driven, externally designed and externally implemented (in the sense of being implemented by persons not from the recipient society). As has been experienced in many other domains where technical assistance follows this model, such efforts usually fail to penetrate the socio-political fabric of 
the recipient society, to identify and nurture local processes of change and to adapt and evolve over time in response to rigorous processes of evaluation.

Despite these weaknesses in the basic approach, it is still much used. Given its fairly obvious shortcomings (it is enough, for example, to observe a political party study tour from a reasonably close distance to see that this is a method fraught with problems) and the consistency of critiques that emerge from recipient parties, why does it show such persistence? First, as noted above, it is a simple, straightforward approach that can be put into place anywhere with little prior study or design. Second, the standard approach reflects the non-developmental mindset common in party aid circles. Most people who staff party aid organisations are experts in politics and parties, not in developmental issues or methods. They are not versed in methods such as nurturing local sources of change and ensuring that external approaches are fully tailored to fit the local realities. Their instinctive inclination instead is straight institutional modelling. Baldly stated, the outlook behind the assistance is: 'We Westerners know how parties are supposed to work and we will teach you, the representatives of parties that are not working as we think parties should, to learn to make your parties work correctly.' Third, most party aid organisations rarely engage in or are required to take part in rigorous, independent evaluations of their work. Thus they are rarely confronted with any challenging, in-depth assessments of what they do that might push them to question their existing methods and try something different.

\section{New approaches}

Although the standard approach persists, some party aid organisations are making efforts to correct some of its deficiencies and to broaden it. With regard to training, for example, some recent or ongoing party aid programmes eschew the usual one-off workshops or seminars in favour of more sustained learning opportunities with structured follow-up in which participants carry out small reform initiatives in their parties to build concretely on what they learned in the trainings. Some programmes avoid the 'fly-in' trainer syndrome and use more experienced outside trainers who stay in the country for enough time to get to know the scene. They provide some sustained contact with participants or 'third-country' trainers, that is, experts from another developing democracy with relevant personal experience in party-building. And at least a few groups are utilising trainerof-trainer methods to spread learning more widely in parties.

Some of the aid organisations that have recently entered the party assistance realm, such as the Netherlands IMD and the IDEA, are taking a somewhat different approach overall. Rather than working directly with the parties in a country to try to help them reform, they are supporting 


\section{Thomas Carothers}

efforts to reform the legal and regulatory framework that governs parties in that country, in work that can be considered party system aid in that it aims to affect the whole system of parties rather than just individual parties. Some of this work is directed at the political party law of the country. Aid providers look for ways to bolster initiatives that call for reform of a problematic political party law (such as one that creates cumbersome obstacles to the establishment of new parties), including not only the rationalisation of basic administrative elements but also the addition of provisions with requirements regarding internal democracy in parties or other 'good party governance' measures.

Another major area of this growing field of party system work focuses on the reform of party financing. Corrupt party financing is a widespread, serious problem throughout the developing and post-communist worlds (and hardly unknown to Western established democracies either), with manifold deleterious effects on the position and development of parties all over. Assistance efforts to stimulate and advance reforms in party finance systems are mushrooming. These include support for changes in the legal frameworks and governmental enforcement bodies that regulate party financing as well as bottom-up initiatives to create a civil society capacity to monitor party finance and push from the bottom up for reforms.

A few aid groups are trying to find ways to get to know a local party scene more deeply before establishing assistance initiatives and to involve the potential recipient parties more thoroughly in the process of designing the assistance. Such efforts include self-evaluation exercises that parties take part in to analyse and articulate their own strengths and weaknesses and in-depth political economy studies of the party landscape to identify the deeper structural causes of party problems. The Dutch IMD has overseen a self-evaluation exercise by parties in Georgia, for example, and the US NDI, with the support of Britain's Department for International Development (DFID), has undertaken political economic studies of the party landscapes in Bolivia and Peru. It is not yet clear whether and how a deeper prior understanding of the party scene in a particular country will translate into aid programmes that differ from conventional ones, but the intention is innovative and worth developing.

Another new emphasis in party aid is the problematic relationship that many parties in emergent democracies have with civil society. Some party aid groups have launched activities to try to help build closer, more mutually productive ties between civil society sectors traditionally suspicious of parties and parties bereft of meaningful contacts with civil society groups. Such programmes typically consist of round table meetings and workshops in which representatives of political parties and civil society organisations meet, with the idea of helping the two sides get to know each other better and perhaps learn to work with each other more effectively. 
These efforts, while based on an important idea - that the lack of societal rootedness of parties in new or struggling democracies is a core problem, not a symptom of weak party organisations or a natural characteristic of parties operating in an early phase of democratisation - have not yet gained much traction where they have been tried. Civil society representatives who attend such meetings often come out of them complaining that the political parties just want to use them for their own purposes and have no interest in real partnership. The political party people, in turn, complain that the civil society activists are only interested in their own issues and look down on political parties.

Some of the problem with the attempts so far to help forge stronger ties between political parties and civil society comes from the narrow definition of civil society that democracy promoters tend to use. They are in the habit of essentially equating civil society with NGOs, especially the rather specialised circle of public interest advocacy and service NGOs that are close to the donor world. These NGOs are only one part of civil society and they are one of the parts that are least likely to want to work closely with parties. They are usually led and peopled by activists who entered the NGO sector as an alternative to a political sector they view as corrupt and unproductive. Their interests in policy advocacy and service delivery lead them to be deeply wary of close association with any party or group of parties. Such an association can stand in the way of obtaining their needed access or co-operation with the government if the 'wrong' party comes to power. These NGOs, very much at the donors' urging, have cultivated the ideal of non-partisanship and a certain technocratic distance from the political melee. They are thus surprised, and rather confused, when they hear now from some Western democracy promoters that they should in fact get involved in building ties to political parties.

For assistance work on this issue to advance, aid providers will have to broaden their scope to take on board a much wider conception of civil society. It is precisely the types of civil society groups that are often not part of donor-funded civil society development programmes - groups oriented toward mobilisation and wide membership, such as teacher's organisations, indigenous persons' groups, informal ethnic associations, professional associations and trade unions - that are more likely to have the sort of political interests and orientation that would lead them to want to work closely with political parties. And party aid groups will need to abandon the idea of party-civil society relationships as a kind of policyoriented partnership and instead figure out how to support the kinds of deeply strategic (and opportunistic) party-civil society relationships that actually exist in established democracies, such as in the intertwining of trade unions and the Labour Party in Britain or the active role that many citizens' interest groups in the United States play in endorsing and raising money for political candidates. 


\section{Thomas Carothers}

Another new approach also addresses the problem of party rootedness, though it focuses on citizens generally rather than NGOs. The idea is to use targeted civic education activities to encourage citizens to get interested in engaging with parties for the sake of protecting or pursuing some set of interests, while simultaneously working with parties to help them better meet citizen's needs. One example from 2005 is a programme in Peru that aims to get parties more focused on poverty reduction policy measures so that parties will learn to try to meet the core needs of citizens. The programme offers civic education to some citizens to raise their awareness about how parties and politicians can (and should) address the issue of poverty reduction while at the same time training parties on how to formulate effective poverty reduction platforms and policies.

As with the work on party-civil society relations, this is an interesting new line of work, yet one that also has yet to show that it can effect substantial changes in how parties relate (or do not relate) to their societies. It is difficult to change the incentive structures that shape parties' behaviour just by changing some of the attitudes of citizens about parties (to the extent civic education can really do that). Parties' problematic relationships to citizens have many entrenched causes, from patronage patterns to social hierarchies, which cannot be easily outweighed by some mild attitudinal shifts. And establishing clear, rational linkages between the policy performance of parties and the preferences and choices of voters is something that takes place only very imperfectly, even in established democracies. In the United States, for example, many voters make notably irrational (viewed strictly in terms of economic causality) judgments about the economic results that presidents are responsible for. And their voting choices often rest on much more specific personalistic or even quixotic factors than a clear-eyed assessment of their economic self-interest and the policy platforms or policy records of competing candidates or parties.

\section{Partisanship}

All types of democracy aid raise questions about political interventionism and the appropriate limits on the roles of outside organisations in trying to affect the political life of other countries. Party aid is especially sensitive because it directly touches the key political actors vying for power and has the clear potential to directly affect the recipient societies' basic political choices. The core issue here is partisanship: do party aid providers adopt and promote favourites, helping certain parties over others for the sake of influencing the outcomes of elections?

Party aid providers usually downplay the idea that their work might be partisan and deny that they might be seeking to influence electoral outcomes. European parties and party foundations say that although they do work with individual parties on the basis of ideological partnership 
(a Western European social democratic party, for example, will work with social democratic parties in other countries), their work in any one recipient country is politically balanced because all the different major parties in their country will be pursuing similar party-to-party relationships and thus an overall ideological balance will prevail. The US party institutes defend against charges of partisanship by arguing that almost all of their party work follows a multiparty approach in which the assistance is offered to all the major parties in any one country.

In fact, however, the picture is not so clear; neat lines and simple conclusions about partisanship in party aid are hard to draw. Concerning European party aid it is true that aid coming from one aid-providing country, such as Germany, Sweden or Britain, may go to several different parties in a recipient country. Yet the idea that an ideological balance in the aid will necessarily be achieved is flawed, for several reasons. First, the parties or party foundations in the aid-providing country may not receive equal amounts of aid themselves and thus their assistance activities will vary in size and scope. In Sweden, for example, the Social Democratic Party's long domination of the electoral scene means that the party foundation tied to that party has long received a much greater amount of funds for international work than the other Swedish party foundations. Thus, on the whole, Swedish party aid abroad is distinctly weighted toward centreleft parties.

Second, even if an aid-providing country's party foundations are relatively balanced in size, their assistance in any single country will not necessarily reflect this balance. The country's right-of-centre foundation may decide to work actively in a country while the country's left-of-centre foundation may decide, for whatever reason, not to work there. Thus in that setting, the aid from that particular aid-providing country will be ideologically weighted in one direction. Third, some of the parties in a recipient country may not match up with European party foundations working there in terms of shared ideology and thus will not be chosen as partners for party aid. In the Middle East, for example, Islamist parties, which are quite active in some countries, are not likely to be chosen by European parties or party foundations operating on the basis of the fraternal party method. Thus European party aid in that region will not be ideologically balanced in terms of the local ideological spectrum.

It is true that most US party aid is multipartisan, yet not all of it is. In the first half of the 1990s in Central and Eastern Europe, the US party institutes often supported centrist and centre-right parties against postcommunist successor parties, reflecting the view that the success of the centrist and centre-right parties was crucial to transitions away from the old communist order, and that these parties faced serious structural disadvantages compared to the post-communist parties. The US institutes defended this work as not being politically partisan in the conventional 
sense but rather pro-democratic - it did not aim to produce a particular electoral outcome but rather simply to level an un-level electoral playing field.

Since the 1990s the US party institutes have been helping coalitions of opposition parties prepare for electoral campaigns against entrenched strongmen regimes in a small but important set of countries, such as Serbia, Belarus, Ukraine and Azerbaijan. These pro-oppositional party aid programmes are often one part of a larger set of US and other Western support for civic and political forces in the country trying to oblige the regime in power to hold a relatively free and fair election. The US party institutes justify what is a clearly partisan line in such situations in a similar fashion as they did in Central and Eastern Europe in the early 1990s - these programmes are not, they argue, attempts to favour one political party over another but rather they are providing aid to a broad democratic bloc standing up to a non-democratic regime.

In short, the issue of partisanship cannot be lightly brushed aside. Some party aid is partisan and the practices of Western party providers in this regard are not always clear and well explained. Inevitably there is much suspicion in many countries on the receiving end of Western political aid about the intentions and interests behind such activities. Partisan party aid easily plays into internal debates over outside intervention and can muddy local political waters by leading some parties to be accused of being Western lackeys or giving citizens the exaggerated impression that their country's electoral outcomes are influenced by powerful outside actors. A growing number of governments around the world, especially in Russia and other parts of the former Soviet Union but also in China, southern Africa, and South America, are actively taking measures to block or curtail Western democracy aid inside their borders. These measures sometimes take the form of tighter legal restrictions on contacts between foreign organisations and political parties, such as a 2003 presidential edict in Belarus prohibiting foreign funding for any politically related activities in the country. At other times there is public criticism or threats by senior government officials directed against parties or civic organisations that receive support from foreign organisations, such as the vituperative comments along these lines by Zimbabwean President Robert Mugabe and Venezuelan President Hugo Chávez. In such a climate, an open discussion across aid-provider and aid-recipient lines about the appropriate types of party aid would be valuable, as well as greater transparency by party aid providers about some of their specific activities in sensitive contexts.

\section{Impact}

Persons who work on party aid, like most persons involved in democracy assistance generally, often project a strong sense of optimism about their 
work. They see tangible problems before them, they feel they have genuinely useful knowledge that could help overcome these problems, and they are determined to have an impact. Party aid programmes often seem to promise transformative effects on the parties in question as aid providers talk of introducing internal democracy, financial transparency, management rationality, ideological coherence and other fundamental changes into deeply troubled parties lacking these and most other elements of what aid providers believe constitutes a good political party. Yet although party aid programmes are redolent with optimism, they are also usually rather vague about what actual impact they promise to have in what time frame. And when disappointments occur, as they often do, there is a call for more time and patience, with little sense of what was a realistic expectation in the first place and what are the genuine prospects for improvement in the near term.

Broadly speaking, there is little evidence for the transformative effects of international party aid. This is clear from the sobering fact that almost everywhere where party aid providers have worked or are working in the developing and post-communist worlds, often for many years, the political parties today embody most or all of the essential deficiencies that motivated party aid providers to get involved in the first place. Bluntly stated, if party aid were having transformative effects, parties would not be in such a profoundly troubled state all over the world. Underlining this basic conclusion is the fact that the largest, most concentrated undertakings in this domain have failed to produce dramatic positive effects. These include the efforts by the main German Stiftungen to strengthen both Christian Democratic and centre-left parties in Latin America during the 1970s and 1980s and the extensive European and US support for centre-right parties in Central and Eastern Europe in the 1990s.

The effects of party aid in various specific countries where Western groups have made a special push in the past 10 to 15 years also highlights the absence of transformative effects. In Russia, more than ten years of US, German and British support for the main two pro-reform parties (Yabloko and the Union of Right Forces) failed to help those parties grow into successful parties. In Romania, the main recipient of the considerable amount of US and European party aid that went to the country in the 1990s, the Peasant Party, ended up collapsing as a result of poor management and a failure of leadership renewal, so disappearing from the political scene. In Mozambique, international aid to help consolidate the party system as the country came out of civil war was helpful in strengthening the main party, FRELIMO (Mozambique Liberation Front), and enabling the principal opposition party, RENAMO (National Resistance of Mozambique), to make the transition from guerrilla movement to political party. But the assistance has not been able to make much headway in leading either of those parties to become more internally democratic or financially transparent and non-corrupt. 


\section{Thomas Carothers}

The problems with the standard approach of party aid described above inevitably weaken the impact of many party assistance programmes. But even if those shortcomings were fully resolved, a combination of other factors having to do with the nature of political parties and the contexts in which they operate in new or struggling democracies would still make it very hard for party aid to have more than very modest positive effects, at best.

First, the leaders of parties in these countries tend to resist the reforms that outside aid providers advocate. Such leaders are usually very strong personalities who have a strong sense of their place in their own society and are not very open to ideas and suggestions coming from outsiders. Even more importantly, these leaders often end up resisting reforms pushed from the outside because the organisational and operational reforms that Western party aid providers advocate threaten to weaken party leaders' hold on power. For example, internal party democracy (probably the most commonly recommended reform by Western party aid representatives) sounds to Western ears as a sensible and necessary step to advance democracy. To most party leaders in these countries, however, it appears as a dangerous step that may undermine the leader's ability to control internal developments in the party, to reward his or her closest associates and cronies and to block potential rivals for the party leadership. Similarly, incorporating women more fully into the party sounds almost self-evidently valuable to Western aid providers but is heard by party leaders as a measure that may break up the hold of their inner circle of loyalists at the top of the party and disrupt traditional patterns of promotion in the party that allow the leader to keep control.

Furthermore, some party leaders in new or struggling democracies have a very different vision than Western party aid groups have about what their party is or aims to be. Thus although they may formally welcome co-operation with outside party aid groups, they do not share their assumed agenda of trying to become a good party in the conventional sense of the term. Obviously, for example, many party leaders view their parties as vehicles for the pursuit of their own personal political ambitions. As a result they may well not be interested in building a long-term party constituency, learning how to represent citizen's interests effectively or effecting any of the other pro-democratic reforms urged upon them by well-intentioned outsiders.

Political parties in new or struggling democracies are also hard to change through external assistance not only because of frequent resistance to reforms on the part of party leaders but because of the chronic institutional weaknesses of these parties (the same weaknesses that draw in outside aid providers looking to help). The weak institutionalisation common to many parties in these countries - the shortage of permanent staff, the incoherent, disorganised management structures, the lack of financial 
resources - makes it hard for them to articulate what kinds of assistance they most need, to take advantage of what aid they are offered and to build over time on whatever short-term progress they make. As with other types of institution-building assistance, party aid providers face the dilemma that those institutions that most need basic organisational strengthening are least well positioned to take advantage of aid dedicated to that end.

Party aid tends to have only rather limited effects not only because parties are hard organisations to try to help but also because parties are shaped by a whole set of underlying conditions and structures that party aid usually has no bearing on. This is a problem with most types of external aid that seek to change a particular institution or set of institutions. The aid almost inevitably focuses on the institution itself, not on all the surrounding forces and factors that play a major role in determining its shape and function. Because parties in many countries are part of the central nervous system of a country's political corpus, the range of such underlying conditions and structures relevant to their development is unusually wide.

Basic features of the overall political system will have significant effects on party development. If, for example, the political space in the country is highly restricted, political parties (other than the governing party) will usually be crippled. And no matter what their level of determination or skills, or what aid, training and advice they receive, they will have difficulty building up their organisational capacity significantly. Moreover, any number of underlying social, economic and other structural features also greatly influence the course and direction of political party development in a society. Widespread poverty and socio-economic marginalisation create fertile ground for clientelism and patronage politics. Weak rule of law encourages corruption, weak accountability and other deformations of party politics. Enduring authoritarian legacies, both psychological and institutional, make it hard for parties to build real ties to citizens. A constricted range of economic policy choices due to pressures of globalisation undercuts ideological differentiation of parties, at least on the standard right-left axis.

At least as it is presently conceived and carried out in most cases, party aid does not address these sorts of broader conditions and structural factors that weigh so heavily on party development. This fact reflects a basic reality of party aid, given the relatively modest amounts of money that aid donors are willing to devote to the issue: party foundations and institutes naturally tend to focus on the more manageable-sized target of the parties themselves rather than on the many larger issues bearing on party development, such as poverty and weak rule of law. At the same time, the tendency of party aid groups usually to focus on working directly with parties reflects the troublesome tendency mentioned above that also 
occurs in some other areas of democracy-related institution-building aid (such as with programmes to reform judiciaries or strengthen parliaments). This is the non-developmental tendency of specialists in a particular kind of institution (whether it is judiciaries, legislatures, parties or something else) to try to strengthen counterpart institutions in other countries using a standard set of institutional-strengthening tools (usually training about how the institution is 'supposed' to work) with little regard for the context in which the institution is embedded.

Although transformative effects of party aid are scarce, modest positive impact is often apparent. If one examines parties that have participated in some party aid programmes, small signs of change can frequently be identified, changes that can be fairly clearly linked with the aid activities. One frequently can observe, for example, an increasing sophistication over time in the campaign methods that parties use. In countries where authoritarianism has just in the past decade or two given way to competitive elections, parties have been scrambling to learn up about electioneering, sharpen their messages, develop better publicity materials, incorporate information gained from polling, be more strategic in the deployment of resources, become more effective at recruiting and using campaign volunteers, and so forth. Although some of this is self-learning (and the Darwinian effect of parties that fail to improve their campaigning losing elections and sometimes disappearing), some of it is also the result of externally sponsored assistance.

The fact that party aid often has fairly definite effects in this domain is not surprising. Many of the elements of effective campaigning are discrete, widely transferable techniques that are not very difficult to teach, and which parties can adopt without having to make major changes in the underlying structures of the party. And most parties perceive a tangible interest in learning these things. Yet though positive effects of campaignrelated assistance are relatively common, drawing a larger judgment about the value of this type of party aid is complicated by a hard question: does helping a party or set of parties in a new or struggling democracy to professionalise its campaign methods advance democracy in that country? One can argue for the affirmative by asserting that through better-organised and better-executed campaigns, parties engage more citizens more effectively in the democratic process and perhaps build the representative function of the party or parties.

Yet a contrary argument is also possible. The professionalisation of election campaigning in established democracies is often blamed as a contributing factor in the loss of citizens' interest in party politics and the hollowing out of modern democracies. Citizens become politically alienated as parties learn to 'focus group' messages and candidates until the messages and candidates seem to say only what the research indicates is most effective for hitting key 'hot buttons', not what the parties or 
candidates actually believe. Many elements of mounting an effective campaign have little to do with creating genuine bonds between parties and constituents but rather treating voters as opportunistic targets for the most superficial and temporary loyalty. It often seems in established democracies that the more artfully parties learn to persuade people to vote for them, the less citizens feel represented by their parties.

One can also observe some parties in new or struggling democracies taking positive steps on organisational development. And in some cases it appears (from analysing the timing of the changes and interviewing key persons within the parties about the process of internal party change) that these steps were prompted by externally funded assistance activities. Many parties around the developing world, for example, have experimented with greater efforts to carry out door-to-door campaigning as a result of training efforts by outside aid providers. Similarly, many parties have taken steps to give women a great role in internal party structures as a consequence of party aid providers pushing on that issue. Changes of this sort are almost always small, incremental steps. In most cases they are piecemeal, sometimes they are part of a larger, though still gradualistic, set of internal reforms. The hard question is whether the small positive steps will deepen over time and cumulate in major organisational changes.

Party aid providers tend to take the optimistic view. They often describe what they are doing as 'planting seeds of change' and argue that over time these seeds will take root and grow into large reforms. Their confidence often seems grounded in a rather vague sense of naturalness about political party development, as though once parties get exposed to the right ideas and have more time to try out new practices they will naturally evolve in the direction of 'good parties'. In many cases, this vague sense is remarkably untouched by an awareness of the deeply rooted reasons internal to the parties themselves and related to the underlying structural conditions why the parties have the organisational characteristics that they do. Since most party aid representatives work in any one country only for several years at a time (at most) before moving on to another assignment, they rarely actually see whether these seeds of change really do take root and grow.

\section{Conclusions}

International aid for political parties is at an important juncture. It is expanding in response to the widespread perception both among democracy specialists and ordinary citizens in many developing and postcommunist countries that political parties are one of the weakest, or even often the weakest, institutional link in the chain of attempted democratisation. Yet it is expanding without a clear sense within the donor community that fundamental questions about such aid have been posed, 
let alone answered, despite decades of work in this domain. This chapter has examined some of these questions with a view to giving at least preliminary answers.

The goals of party aid are, in fact, clear, but what is not clear is whether they are coherent. It is puzzling and perhaps problematic to expect parties in new or struggling democracies to develop along pre-defined (by Western party experts) organisational and operational lines that many parties in established democracies do not follow. At a minimum the goals of party aid often seem unrealistic; more seriously, in some cases they may simply be a bad fit relative to local circumstances.

The standard approach of party aid, which is based on the same institutional modelling approach that democracy promoters employ in most areas of their work, is often criticised by persons on the receiving end of such efforts. The most common criticism portrays party aid as a supplydriven domain marked by mechanistic training and other activities that are poorly adapted to local realities and not designed to foster long-term, widely disseminated learning within parties. Some aid providers are attempting to improve the standard approach but a lack of challenging evaluations of party aid allow some aid providers to keep doing the same thing over and over, despite limited effectiveness.

Although party aid providers almost always insist that party aid is nonpartisan and does not seek to influence the outcome of elections, in practice significant elements of partisanship can be found in both European and US party aid. Such partisanship is not necessarily illegitimate, but given the current global context of heightened controversy about Western democracy promotion generally, it can create suspicion that party aid is being used for the pursuit of narrow regime change goals rather than broader pro-democratic ones.

Party aid rarely has transformative effects and the troubled state of parties in most new or struggling democracies is likely to continue for some time, despite the best efforts of well-intentioned aid actors and their local counterparts. The absence of transformative effects reflects the fact that party leaders often resist the reforms aid providers urge on them and that most parties in the aid-receiving countries are difficult organisations to assist due to their core institutional weaknesses. It is also due to fact that party aid does not get at the underlying socio-political and socioeconomic structures and conditions that shape parties. Party aid does have modest positive effects in some cases, both in the electoral campaign capacities of parties, and their basic organisational development.

As party aid expands and evolves, some new approaches are surfacing. These include work on party systems rather than directly on parties themselves, improved training methods, more in-depth analysis of a political party landscape prior to designing an aid intervention, efforts to connect parties with civil society, and activities aimed at fostering citizen demand for better parties. Some of the new actors entering the party aid field, 
such as regional multilateral organisations, are emphasising these new methods. The traditional party foundations and institutes that have long worked in this area are also broadening their traditional approaches as the search continues for the best ways to meet the daunting challenge for democratisation presented by troubled political parties all around the world.

\section{Note}

1 Between 2003 and 2005 the author carried out field research on Western political party aid programmes in Russia, Romania, Morocco, Mozambique, Guatemala and Indonesia as well as numerous interviews with representatives in the headquarters of European and American party aid organisations. 


\title{
5 East-Central Europe \\ Parties in crisis and the external and internal Europeanisation of the party systems
}

\author{
Attila Ágh
}

\section{Introduction: the dual pressure of Europeanisation and social consolidation}

The party systems in East-Central Europe (ECE) have emerged under a series of dual pressures from inside and outside. The general framework of the external adaptation pressure has been the globalisation cum Europeanisation challenge, since globalisation has mostly impacted upon the ECE countries through the Europeanisation process. This challenge, however, has been so strong, so overwhelming that this external adaptation pressure has dominated the domestic processes. In the early 1990s the global financial institutions, notably the World Bank and International Monetary Fund appeared as institutional tutors in ECE. But their direct influence soon vanished and the main external pressures for democratic transition and consolidation since then have been exerted upon the ECE states by the EU's accession 'conditionalities' (Hughes, Sasse and Gordon, 2004; Pridham, 2005). The EU pressure began with the Association Treaty process and even after completion of entry by the new member states it still impacts heavily on their domestic transformations. A previous distinction made by the author to assess these processes has been between anticipative and adaptive Europeanisation, as stages before and after the accession negotiations (1998-2002); but it is the next stage of postaccession Europeanisation that merits close attention now. Given the very asymmetrical dependency relationship in this particular Europeanisation process, it is indeed the case that the strikingly successful examples of democratisation in ECE probably have very limited application elsewhere. So this chapter explores how Europeanisation - as both promotion of democracy and requirement of multilevel governance - has influenced in this specific regional framework the process of party-building in ECE. It analyses the three stages - anticipative, adaptive and post-accession and characterises both ECE parties and party systems in this historical sequence. ${ }^{1}$ 
The central thesis of this chapter is that the process of emergence of the ECE party systems has now come to an end, and a new period has begun with a general crisis of the ECE parties and party systems. The ECE governments and party systems have been shaken by a dual pressure, having to face the European Union's convergence criteria from outside and high expectation from the ECE populations for a 'normal' standard of living and public services from inside. This turning point can also be described as a tension between adaptation to the EU by completing the membership process (institutional reforms, euro-zone and Schengen acquis) and social consolidation in the new member states (reaching the 'normal' level of standard of living and public services). Thus, the historical turning point with the entry to the EU has provoked a general crisis of the ECE party systems that can be characterised as the socio-political senilisation of parties and party leaderships after just 15 years and that has been aggravated by the unsettling effects of the EU membership. The ECE parties have been programmed for transition and accession, and both goals have now been attained. These parties, however, have no new programmes and no new messages to offer in the current period. The party elites in general have become, at least socio-politically, 'old', tired and extremely unpopular. Even many young politicians are, in fact, very 'old' since they have been over-socialised by the former generations of politicians, and they have developed the same kind of familiar outdated or old-fashioned patterns in political culture (examples are Viktor Orbán in Hungary and Stanislav Gross in the Czech Republic).

Altogether, this party crisis has also contributed to a crisis in theory, which Ágh (2005a) terms 'the glorious failure of transitology and humble success of Europeanization'. It means that theories of democratisation based around the sequence of transition and consolidation have proven inadequate to conceptualising the actual processes in ECE, since they have been imported from Latin America and southern Europe, and not adapted to Central Europe. In addition, they have been so over-generalised in a 'post-communist' frame of reference that these theories have been unable to grasp the essence of the specific ECE regional transformations. Although previous attempts have tried to construct a notion of 'early consolidation' to reflect the special character of the ECE developments, in reality no such fine-tuning of the established democratisation theory can suffice to describe the ECE specificity. In fact, the main reason for the failure of transitology-consolidology is that the European integration has taken place under very different conditions in Central Europe than in southern Europe two decades ago: in ECE the external adaptation pressure has been much bigger and more asymmetrical. Consequently, Europeanisation is the key term to explain the ECE transformations, although 'Europeanisationcum-democratisation' may be as relevant for indicating that the major advances of democratisation have basically been under the direct pressure of Europeanisation, and its concrete forms shaped by EU requirements. 
The external adaptation pressures also include the emergence and functioning of the ECE party systems, since Europeanisation has appeared more strongly in 'particisation', including the 'transnational elite socialization' (Pridham, 2005: 16), than in any other fields of political transformation. Finding EU partners has been the only route to legitimacy and guarantee for survival of the ECE parties.

\section{Emergence of the ECE party systems: the blurred identities}

\section{External and internal Europeanisation of the ECE parties}

The evolution of the party landscape in the EU can be summarised as a long process of change from the party systems of industrial society based on materialist values and class cleavages to those of post-industrial service society based on post-materialist values and culturally oriented social cleavages. This also gives a clue to the language of 'new left' and 'new right' parties as basic transformations in party politics. The new left has differed from the old left because of its rejection of class-based politics and embrace of participatory and decentralised forms of party membership. The main issues on the agenda of the new right has been taxation, immigration and radical regionalism, in addition to anti-political and antielitist forms of protest that have been clear crisis phenomena of the declining industrial society and its social strata leading to social and national populism (Cole, 2005). These Western conditions of radical transformations on both the left and right have had major consequences for the emergence of the ECE parties and party systems, the main actors in new democracies. Domestic conditions and the internal logic of partybuilding have also been important, but adaptation to the Western requirements has been the dominant feature.

From the side of Europeanisation the real process of emergence and/or adaptation of the ECE party systems began in the late 1990s. In fact, some 'anticipative' Europeanisation of the ECE parties can be observed already in the early 1990s. But it was so embedded in the more general requirements of democratisation then that the real specificity of Europeanisation as a special accommodation to the EU parties and party systems was not yet felt, and was not demanded either. Thus the period between 1990 and 2004 was a period of premature party systems, consisting of mainly two major sub-periods: first, general democratisation and/or anticipatory Europeanisation, up until 1998; and second, a special EU kind of democratisation and adaptive Europeanisation until 2004. These two subperiods should be kept clearly distinct, since after the start of accession negotiations specific EU issues increasingly began to dominate in the lives of the ECE citizens, and direct Europeanisation was high on the party agenda as well. 
EU entry has brought a clear turning point for the ECE parties, because it has meant a direct participation for them in the EU's activities. The specific Europeanisation pressure upon them increased greatly with the preparation for the elections to the European Parliament in June 2004. It resulted in a radical adaptation by ECE MEPs to the party groups in the EP. Party performance in ECE and the present 'performance crisis' of the parties and their national parliaments on entering the EU have brought new challenges for the parties' political, administrative and absorption capacities, facing the demands for effective membership with all the features of multilevel governance, sub-national democracy, regional development and decentralisation. Thus, the main adaptation pressure has only begun for the parties inside the EU with its long and painful learning process for the party elites. The following discusses the premature, transitory party systems up to entry, then the crisis and near collapse of these transitory party systems from the side of a 'participation paradox' before, finally, outlining the EU requirements placed on ECE parties in the present, post-accession period, which we can call an emerging 'postLisbon democracy'. ${ }^{2}$

So far, little attention has been paid to the participation of ECE parties in the European party system, although the relationships between the national parties and party formations at the EU level have been discussed since the early days (Gaffney, 1996; Hix, 1996; Hix, Kreppel and Noury, 2003). The dominant view about the influence of the EU upon the national party systems has been one of 'limited impact'. But this is defective because it ignores the distinction between the external and internal Europeanisation of the ECE parties, since the Europeanisation has been very 'direct' or hard on one side while very 'indirect' or soft on the other. External Europeanisation is an elite-based process through which contacts with and/or membership in the international party organisations appear and the ECE parties' programmes, values and public discourses change accordingly. By comparison internal Europeanisation is a process reaching and transforming the membership, the constituency of the ECE parties and their relationship to the civil society through which the internal party organisations and popular beliefs change accordingly. In fact, external Europeanisation has proceeded in the above mentioned two - anticipatory and adaptive - stages, and in ways that produced a 'limited' but nevertheless growing impact on the side of internal Europeanisation. The first stage may be called, again, general democratisation, and the second was the stage of partial integration. In fact, these initial stages of European integration produced a split between the external and the internal Europeanisation of the ECE parties, with a growing contrast between their international and domestic activities. In the present post-accession stage, this tension has sharpened, since the activities of the ECE parties in the EP have provoked an acute conflict between the MEPs and the 'domestic party', in the process unleashing a reform drive at home. In the near 


\section{Attila Ágh}

future, certainly by the end of this parliamentary cycle in 2009, Europeanisation will penetrate much more into the domestic structures of the ECE parties as well, so creating an opportunity to shape their alternatives for national strategy, too. ${ }^{3}$

Fundamentally, external Europeanisation is a process through which contacts have been established with Western parties and party internationals, including membership of the international party organisations. As a result, the parties have shaped a Western type of image or outlook for themselves (international party). Internal Europeanisation as a mass-based process is the transformation of such basic party features as membership and organisation to approximate more closely to the Westerntype parties in their internal structures, including the relationship to the party constituency and to civil society as a whole (domestic party). So far, external Europeanisation has only scratched the surface of the ECE parties. Europeanisation has appeared only through the established official contacts and the informal meetings of a very few party leaders with their Western European counterparts. The bulk of the party membership and the population at large have not been informed very much about the discussions of the EU left and right, international social democracy or Christian democracy, and so on. The reason is simple: namely, the problems and concerns are so different that most of the population are unable to decode recent Western discourse about the 'third way' and the like, since ECE societies remain preoccupied with their domestic difficulties and cannot escape from the trap of materialist needs. It is true, however, that EU membership has also brought some changes in this respect. Issues that are specifically EU problems have been brought to the attention of a large part of the ECE populations and these may provoke in the coming years a complex and controversial process of internal Europeanisation of the ECE parties.

All these arguments point in the same direction: the ECE parties have not yet been completely prepared for assuming the rights and duties of membership in the EU-level parties. Given both the low degree of their external Europeanisation and the internal weaknesses, the ECE parties have been lagging behind in both policy co-operation and strategy-making. This is only 'thin' - rather than 'thick' - Europeanisation. A similar situation has obtained in the case of other member states when they were new, for example, Ireland and also Greece, Portugal and Spain. But there are two big differences. First, when the Mediterranean states entered, the EU worked at a lower level of complexity than now. For instance there was no globalisation-oriented Lisbon Strategy to cope with. Nowadays the main political actors face greatly increased demands both for policy co-ordination and for more strategic thinking. Second, the Western European sister parties offered very active assistance to the Spanish and Portuguese parties, and, notwithstanding significant assistance from Western political foundations such as Germany's Friedrich Ebert Foundation 
and Konrad Adenauer Foundation, nothing of comparable size happened in the case of the ECE parties.

\section{Left-right and nation-Europe co-ordinates in the ECE party systems}

The external-internal Europeanisation duality leads to the issue of ECE party identities as a result of their relation to the EU. First, the party cleavages at the EU level will be described, in order to situate the ECE parties. There are two basic if as yet underdeveloped cleavages in the Euro-polity: the federalist-intergovernmental and the left-right cleavages. They give four possible combinations, but they are not equally strong and influential, since only the EU right has divided into sizeable anti-European and pro-European wings, as two different cultural camps. Conservatives in general stress cultural identity, family values, and law and order, but among them even the moderate Euro-sceptic parties favour an intergovernmental approach in order to preserve national capacities to shape policies. Moderate Eurosceptic parties may be considered as 'liberals' from an economics point of view, since they support only the integration of markets and not that of institutions. On the other hand, the leftist parties have become more proEuropean, and only some of the smaller extreme-left parties tend to be anti-European. Social democrats insist on the EU's engagement in social affairs and added goals such as full employment and social inclusion to the list of EU tasks. (Dauderstädt, 2004: 12-13).

Turning to the domestic idiosyncrasies of the new member states, there is a big and increasing divide between the pro-European and anti-European forces. The ECE parties can be situated according to the left-right and nation-Europe coordinates. Thus, the ECE parties can be described according to the two axes of left/right and Europeanisation/nation-centrism (or traditionalism). This typology generates four basic types of ECE parties: Europeanised left and Europeanised right, and nation-centric left and nation-centric right. This dual divide has distorted both types: the centreleft suffers from the trap of materialist needs and crisis management, the centre-right from the contradictions of Europeanisation. Accordingly, the ECE right is much more populist and Euro-sceptic than the right-wing parties in the older member states of the EU. It favours the idea of an EU of nation states much more than its sister parties in the West, unlike the ECE left, which is more supportive of closer EU integration but has been frustrated by the failure to come closer to the model of 'Social Europe', which in turn has led to its leftist credentials being questioned by friends and foes alike. What we see, then, are blurred and uncertain identities on both left and right. It is difficult to find a really pro-European centre-right party in ECE, and impossible to identify a centre-left party with a marked leftist programme (Crook, Dauderstädt and Gerrits, 2002; Gerrits, 2002). 
The clear cases of both hard and soft party-based Euro-scepticism on the right could be observed as early as the late 1990s in all the accession candidate states. The real turning point came in the second half of the decade when the soft party-based Euro-scepticism appeared in its explicit form among the governing right-wing parties in Poland and Hungary especially. In Hungary, soft Euro-scepticism is taken up by two parties in the governing coalition, FIDESZ as the major party and the Small-holders Party as the junior partner. FIDESZ's leader, premier Victor Orbán, increasingly adopted 'national interest Euroscepticism' (Taggart and Szczerbiak, 2001: 18). In this spirit, even the more consolidated conservative parties made a populist turn at that time, or courted some Euro-sceptic ideas.

By the late 1990s, however, the lack of real debate, and the perception that these countries were kowtowing to an exploitative EU, began to create the opportunities for more populist leaders to arise and succeed, even where populism had earlier been discredited. Thus, in its rightward shift, Viktor Orbán's FIDESZ in Hungary exploited popular discontent and blamed the EU. Similarly, former Czech prime minister Vaclav Klaus, once ousted from power, turned to Euro-scepticism as a way to regain popularity, speaking out about the EU's 'creeping silent unification of the continent'. In Poland, finally, a fourth of the seats in the fall 2001 elections have been claimed by anti-Union parties.

(Grzymala-Busse and Innes, 2003: 69)

The demobilisation of the masses was, in some ways, a conscious process in the early 1990s by parties and politicians eager to avoid populism. But it was much more an unintended result of economic and social marginalisation. This has led - by the late 1990s - to an 'unstructured political market' with a low membership density for the parties (von Beyme, 2001: 139, 153), together with a strong national-social populism. The main reason for the general crisis of the ECE party systems is the absence of a new message and the lack of new programmes as a result of the dual pressure and blurred party identities in ECE. It has also appeared in the form of a lack of new party elites (or the senilisation of the old party elite) and a shortage of relevant political capacities and skills in the new period of the EU membership. ${ }^{4}$

\section{General crisis of party systems as participation deficit}

\section{From general mobilisation to party-induced demobilisation}

In the description of the general crisis of the ECE party systems the term 'crisis' is justifiable on two counts. First, at an empirical level there has been a protracted accession-related government crisis in Poland and the Czech Republic, with crises in Slovenia and Hungary as well; the Baltic 
states have been affected, too. As usual, the government situation as well as the party crisis has been the most dramatic in Poland. Both there and in the Czech Republic the governing parties almost completely lost their popular support, provoking a collapse of the party system as a whole in Poland. Parties and party systems, however, have been basically transformed in all ECE states. For instance, in Hungary in August 2004 there was a 'popular uprising' against the party leadership, and its official candidate for the post of prime minister was voted down. An 'opposition candidate' emerged with wide popular support, who received more than two-thirds of the vote in an extraordinary party congress that led to the dismissal of the party leadership in October 2004. Second, through this ECE party crisis, the vital issue of political mobilisation-demobilisation has come to the fore, and this has unleashed a basic transformation in the parties and party systems.

The ECE participation paradox is that the ECE parties initiated the change from mass mobilisation to political demobilisation in the early 1990s. The ensuing economic transformations - as transition costs earlier and accession costs later - have also resulted in mass 'economic' demobilisation, and widespread social exclusion has followed from that. In the initial period of economic transformation millions of jobs were lost across all the ECE countries. The effects have been accelerated and deepened by the parties' conscious efforts at political demobilisation, intended to turn them into the only or main political actors in society. At the same time parties have been fighting for the electoral remobilisation of population, rather unsuccessfully. Both the actions for political demobilisation in general and the political remobilisation for elections in particular have their origins in the basic weakness of parties as 'small size mass parties'. The memberships of the ECE parliamentary parties lie within the range 10,000-40,000, except for the Czech Communist Party, which is greater. This means party membership is tiny compared to the number of voters for that given party, possibly 100:1 as an ECE average. The social base of the ECE parties has been very weak, and further erosion of the party memberships has taken place since 1999 (Kostelecky, 2002; Ka-Lok Chan, 2003; Sikk, 2005). ${ }^{5}$

Since the early 1990s the populations of the ECE countries have divided more and more into passive and active sectors. Democracy, however, needs participation as 'organisational underpinnings' and a large variety of institutions acting as connections between culture, social structure and political institutions. These provide a system of social and political integration through the structure and density of social participation. Political integration or involvement means providing channels of representation for all organised groups. Truly consolidated democracy goes beyond a multiparty system to a multi-actor democracy, but that has not yet emerged in the ECE. Even the parties have remained weak, not despite but because of 
their monopolising efforts. Democratic consolidation cannot be successful without 'inviting back' a large part of the passive sector, perhaps as much as half of the entire population, to participate in national and municipal politics. Political inclusion also means articulating their anti-EU views in a coherent form, to replace the outbursts of emotion that form a political undercurrent. There is a danger that there will seem to be no alternative for a rather large segment of the population but to join 'anomical' movements, with support for extreme right-wing populist or anti-political parties being entertained as a likely option.

\section{The 'infantile disease' and social deficit in ECE}

The paradox is still there: popular participation is very unequal in elections and referendums and yet everybody would consider the institutionalisation (let alone the legalisation) of unequal voting and other participation patterns (for instance special voting rights for wealthier and better educated people) to be highly undemocratic. There is a clear contrast between the ECE young democracies and their counterparts in Western Europe, given the drastic decline in social and political participation the ECE states have witnessed soon after the early mobilisation phase of systemic change and before the participatory revolution has yet to be completed. This contrast between Eastern and Western Europe created by the rise and decline of participation in such a short time offers the key to understanding the weaknesses of political representation in ECE, including the ECE parties.

As the very low economic activity rate and very low electoral turnout - both slightly above 50 per cent - demonstrate, systemic change following EU accession has resulted in the social and political exclusion of up to half of the population. The ECE countries have turned their economic deficits into social deficits by imposing drastic reductions in public services such as health care, education and social security, and they have turned these into political deficit by social exclusion and marginalisation. And these have been turned into a democratic deficit by the mass dissatisfaction with the way democracy works, including the way the process of $\mathrm{EU}$ accession has been managed by the governments, with no attempt to integrate the population at large into the larger community. Altogether, the ECE countries have cumulated a huge social and political deficit that will mark Central European history for some generations to come. It is more than the typical kind of historically inherited 'infantile disease' of new democracies, usually conceptualised as a weakness of civil society. For what we see in ECE is a complex exclusion of losers. That means the social capital for the effective and efficient workings of representative democracy is still largely missing. After completing legal-formal 'constitutional consolidation', the ECE countries have yet to reached 
'representative consolidation', through the completion of intermediary organisations, and social 'integrative consolidation', through eliminating anti-systemic movements. Finally, they have not yet reached the 'attitudinal consolidation' that is required if citizens are to take part in political life with firm democratic values.

Before entry to the EU the ECE governments were, in fact, under the double pressure to make a full adjustment to the EU's requirements and to meet their own society's expectations to represent their countries effectively in the accession process. Here the representation and participation paradoxes meet. The governments could not represent their countries properly, since they did not allow their populations as a pluralised and organised civil society to participate in Europeanisation in general and in the accession negotiations in particular. In contrast in the Nordic extension of the EU, the countries concerned invited their social actors to the accession process, including the negotiations, very intensively. The ECE states denied their organised civil society this opportunity and offered them only meaningless 'consultations'; even their parliaments participated in the accession process only very marginally. The ECE governments have often been accused of a lack of social sensitivity and political responsiveness. So far the governments have been 'flying blind'; their populations have seen changing the government through elections as the only means to influence government. Indeed, in ECE there have been very few cases where governments have been re-elected. The democratic deficit with the representation and participation paradoxes has been very marked in the ECE region, inflated by low levels of trust in public institutions such that people and organised interests do not easily accept the opinions and guidance of their governments and parties. The political parties so far have been both unable and unwilling to mobilise the ECE populations to take part in the Europeanisation process. They have acted as a party 'cartel' in favour of Europeanisation as an elite-driven process, and in the spirit of over-particisation. They have been reluctant to give up their monopolistic approach to politics and allow a greater role for policy channels, organised interests, territorial actors and civil society associations in the Europeanisation process. At the same time they have been unable to thematise and concretise Europeanisation for their constituencies, so deepening the accession democratic deficit in ECE. This elitist approach by the parties has been one of the major reasons for turning the 'Euro-phoria' to 'Euro-fatigue' in ECE.

So, ECE has a new challenge: to remove the representation and participation deficit, and even more so to solve the representation crisis through involvement of the whole population in politics, including the Europeanisation process. A better-informed and more organised participation of the ECE countries' populations is urgently needed if there is to be a large and balanced popular support for the Europeanisation process. ${ }^{6}$ 


\section{The future of the ECE party systems}

Following accession to the EU the ECE parties on the right have emphasised even more the dangers that EU integration holds for their countries, and in order to exploit the increasingly Euro-pessimistic mood they have become more Euro-sceptic than before. The ECE parties on the left have remained faithful to the ideals of 'Social Europe' but have been facing even more the contrast between their EU-related promises and the high expectations of the population for a 'normal' standard of living and improved public services. However, very few ECE parties oppose EU membership or are openly anti-European; only a few extreme right parties espouse a hard Euro-sceptic position, and this is mainly in Poland. At the same time, even some well-established parties such as FIDESZ in Hungary have tried to combine national populism with social populism, as have all the Slovak parties on the right. Thus the danger of an increase in populism is very real. Renewed restrictions in social policy could provoke quite angry populist reactions, 'hunger riots' even, like those seen in eastern Slovakia in March 2004. But although the populist demagoguery contains some references to unilateral dependence on 'Brussels' in the way that 'Moscow' used to be referred to, so far the ECE populations are not as sensitive to the fact that decision-making processes have become concentrated in the EU institutions, that is to say 'above them', as are the citizens in some of the longer established member states such as Britain. 'Eastern' populism has formulated its basic slogans more in the terms of social demands than in those of 'national sovereignty', whereas combinations of social and national populisms have been rather widespread. Again, the populations of the ECE countries do not formulate their Euro-sceptic feeling in a similar way to their Western European counterparts, that is, in terms of the EU 'democratic deficit', for they perceive a greater democratic deficit at home, in their own national political systems.

EU membership also unleashes party competition for elaborating the national strategy, based around the contrasting social preferences and value systems of the different ECE parties. In general, party competition seems to be sharpening in the EP and this could lead to an increase in polarisation of the parties inside the ECE countries as well. At the same time the workings of the EP as a policy-making body will produce more convergence among the ECE parties, as they are pushed away from the ideological battles and towards more practical, policy-oriented issues (Bonoli and Powell, 2004). Yet a profound cleavage can also be seen between the old and the new member states concerning the evaluation of domestic democracy versus EU-level democracy. EU-level democracy is appreciated more keenly in the newer members from ECE - a feature that is shared with, for instance, Portugal, where respect for EU democracy still seems much greater than for the nation's own democracy. 'While Italians, Portuguese and Greeks are extremely dissatisfied with the working 
of their national democracy, at the other end of the scale Danish, Dutch and Irish citizens seem relatively satisfied' (Krouwel, 2004: 10).

The degree of satisfaction with the EU institutional order in the ECE democracies differs from the established old democracies, and it has been an important pulling factor towards membership. The populations of the new member states have been open in many ways to a transfer of democracy from EU institutions and have been much less sensitive to the EU democracy deficit because of their own national dual - democracy and performance - deficit. Although anti-European and/or Euro-sceptic parties have 'imported' or fabricated home-made anti-Brussels slogans, this is still less important than the dissatisfaction with the workings of democracy at home. This feeling of a democracy deficit at home in the ECE states has mainly been caused by the parties. It is a product of the general crisis of the party systems, which has deepened subsequent to European entry. The claims made here are confirmed by Johnson's findings from the Eurobarometer:

The new member states are more favourably disposed to European political institutions than to national ones. In large part, this is probably driven more by negative feelings about domestic political systems and politicians than about European institutions, about which they have insufficient knowledge and experience to make a judgement. As yet, there are few signs of developing concerns about democratic deficits in the EU.

(Johnson, 2005: 128)

Indeed, people even look forward to a further transfer of democracy from the EU, converting their countries from formal to more fully effective membership.

In contrast, the ECE parties themselves seem happy to continue with the general demobilisation of the population, even after the remobilisation failure of the first EP elections and the emergence of widening participation and political inclusion as central themes in the discourse of democratisation worldwide. In the ECE it is the uneven levels of political participation in society and limited access to political representatives that stand in need of radical correction, in this post-Lisbon multilevel and multi-actor democracy. Demobilisation of the people is now the biggest obstacle to further democratisation in ECE because the organisations of civil society that flourished in the late 1980s/early 1990s have been turned into, or are now subjected to, mere party politics. At their present stage of party development the parties in ECE must work harder to establish connections in the spirit of partnership with the actors in the policy communities and networks, if popular satisfaction with democracy is to increase. 
Satisfaction with representative democracy has two aspects: satisfaction with the democratic character of institutions (formal-procedural side) and satisfaction with the performance of democracy or democratic governance (policy-efficiency side). These two sides can also be separated in the West, since the formal criteria have lost and the efficiency criteria have gained some significance for the general public. The general concept of 'the people's interest in politics' relates more and more to the dimensions of the performance of democracy. In an overview of the discussions on democratic deficit and satisfaction with democracy Linde and Ekman (2003: 393) have constructed a five-fold model of popular support, further developing David Easton's earlier model of a three-fold distinction: (1) diffuse support for the political or national community, which indicates a basic attachment to a political system; the distinction between (2) regime principles and (3) regime performance in order to account for the difference between support for the democracy as an ideal and attitudes towards the way democracy works in practice; (4) support for political institutions in general or for specific institutions in particular; and finally (5) support for political actors, which has to do with support for a particular person and/or a political party.

This sophisticated approach to political support enables Linde and Ekman to offer a detailed and nuanced analysis of satisfaction with democracy based on Central and Eastern Eurobarometer (CEEB) data. Their most important finding is that support for democracy in principle has been divorced from satisfaction with democracy as it works: the overwhelming majority of the population still supports democracy as a political system in general but has become deeply disappointed with the practice of democratic regimes. Linde and Ekman say 'a respondent can be a convinced democrat, rejecting all forms of non-democratic alternatives, but nonetheless be dissatisfied with the way democracy works in his or her country at a specific point of time' (2003: 396). Indeed, according to the CEEB data, immediately before EU accession only 28, 32 and 35 per cent of citizens were satisfied with the way democracy was working in Slovakia, the Czech Republic and Hungary respectively (Linde and Ekman, 2003: 401-5). In time this could come to have implications for how these countries participate in the EU. Thus as Slomczynski and Shabad concluded in regard to Poland:

As scholars, and, somewhat more belatedly, European and domestic elites of the EU Member States have come to realize, public opinion plays a significant role in shaping the scope and pace of integration. (...) As these countries gain entry, public support will continue to be crucial for the political and economic outcomes of EU enlargement. 


\section{Conclusion: Europeanisation as a proxy for globalisation}

This chapter has argued that the direct impact of globalisation on the ECE parties and party systems has been relatively minor, except for some years in the early 1990s when these parties were only just taking shape. But if the direct economic impact of globalisation has been slight, this is because the parties and party systems have been facing much stronger pressure from both the EU conditionalities in general and the EU parties and party internationals in particular. The challenges connected with meeting the convergence criteria for entering the eurozone, the acceptance and introduction of the Schengen acquis (on the free movement of people within the EU) and joining the Lisbon strategy have been dominant, which makes the emergence of the ECE party systems rather unique. This extremely outward-oriented political development has been indeed a 'return to Europe', where copying the EU institutions has been the only way to get an entry ticket. The 'forced course development', as it has been called, has been very positive; although it has aggravated some contradictions, it has still been a privileged or 'king's way' to EU membership.

In the first decade of Europeanisation a 'party cartel' was formed in support of joining the EU. Most ECE parties supported EU membership and the voices of dissent were marginalised; anti-European or Euro-sceptic opinions were forced underground or minimised. The situation changed radically after closing the accession negotiations in December 2002 at the Copenhagen Summit since there was a turning away from ideologically based political issues to the very pragmatic, even financially based, policy issues. Both left and right began a nested game: the parties on the right introduced a double talk for the domestic and international audience, playing with the 'national card', while parties on the left continued to blame 'Europe' for the austerity measures and for the divergence from the model of Social Europe. Under these circumstances it has become increasingly difficult to reach a national consensus between and among the ECE parties. This has unleashed a vicious circle in the process of structural adaptation to the EU, although this has been counterbalanced to a great extent by the constraints coming from the European Parliament and from the common pressures applying to all MEPs.

Certainly the ECE political systems, including the party systems, have radically changed with membership of the EU. However, the political system of the EU as a whole has also changed beyond recognition with the Eastern enlargement and the emergence of the enlarged EU25. It has changed much more than in the case of former enlargements, not just because this most recent enlargement has been larger but also because of the specific problems of the new entrants. In the writer's view, the politicians and analysts of the former member states have not yet realised this fact, since they have been accustomed to the asymmetries of the Eastern enlargement process, in which it has been for newcomers to adapt to the 


\section{Attila Ágh}

incumbents. But now the old member states have to face the fact that there is also an adaptation process for them, not because of the political will or political capacity of the new members (whose ability to gain significant concessions from the EU remains very low) but because Eastern enlargement has brought a new political landscape and new socio-economic situation. There is now enlargement fatigue, as a new form of Euro-fatigue (on how this might be significant for party politics in Turkey, see Chapter 7). The populations of the new member states have not been enthusiastic about the further enlargements either, although they see more the advantages of including Croatia, Bulgaria and Romania as new members in the near future. They do share the view of many people in Western Europe that the borders of the EU should be stabilised for a long time to come, once accession has been achieved by the western Balkans. Following the most recent round of accession, then, the EU political system as a whole has radically changed.

As to the party systems, there has been a very strong convergence due to the external Europeanisation process, but not at the expense of losing the idiosyncrasies that ECE party systems share. The main specifics of the ECE parties are, first, that they have been 'small size mass parties'. The ECE populations have not joined parties in great numbers, in contrast to earlier experience in the West, and so the ECE parties have a 'head' but they do not have a 'body'. Second, they can be classified, therefore, as an 'office-seeking' cadre party, since the small membership is just enough to provide the political elite. Third, their structuring principle has been based much more on cultural than social cleavages, since cultural traditions and 'camps' matter. Fourth, they have still been much more oriented to ideology than policy, so the policy turn that is required in order to deal with the EU policy universe has caused major problems for the parties. Finally, there has been a bigger divide between left and right than in the West, and this has almost completely excluded compromises, coalitionmaking and the reaching of a national consensus between them. All in all, the ECE parties are not yet ready for the post-Lisbon multi-actor democracy, where social and territorial actors are expected to play a larger role due to decentralisation to the regional level. However, it is quite possible that the parties will be remodelled, once again, under completely different circumstances in the EU 'inside', compared to the 1990s when they were 'outside'. The external adaptation pressure works for the ECE parties in the EU much more now than before.

In sum, the ECE democratisation has been a party-based development but with the emergence of much weaker parties than in the West. The impact of the international organisations and/or the parties in the West has been mostly positive but much less intensive than in the case of the southern European countries in the 1980s. The party-based democracy in ECE has been affected by Europeanisation-cum-globalisation in an asymmetrical way. The political actions have been much more beneficial than 
the social effects of the EU membership, which explains the lack of social consolidation, which has provoked national-social populist tendencies. Finally, regionalisation has taken the form of Europeanisation, initiating a growing homogenisation in the ECE countries. All in all, the partybased democracy in ECE has been stable and weak at the same time. It is now facing further drastic transformations within the EU in the direction of the internal Europeanisation of the ECE parties.

\section{Notes}

1 The ECE region covers Poland, Czech Republic, Slovakia, Hungary, Slovenia and Croatia. The parties and party systems of Slovakia and Croatia - engaged in the early nation-building process - have shown some particular features. Slovak political scientists have elaborated the terminology of standard or nonstandard parties according to the criteria of fitting to the European party systems or not (see Henderson, 2004). This chapter refers mostly to the Polish, Czech and Hungarian cases, drawing on Pridham and Ágh, 2001.

2 At the Lisbon summit in 2000 EU heads agreed a Lisbon Strategy for Growth and Jobs, setting targets of 3 per cent average annual economic growth and 20 million new jobs by 2010.

3 Krouwel (2004: 5) summarises two tendencies in political parties literature: Peter Mair sees little evidence of the emergence of a genuine European party system; but Simon Hix finds that party cohesion at the EU level is increasing.

4 See Ágh, 2005b and 2006. It has often been mentioned that the organisational linkages with society are weak. The ECE parties are elitist and top-down organisations, live on state subsidies and have a high degree of centralisation. They also have a high number of party employees in their headquarters compared to the size of membership (van Biezen, 2005: 156, 159, 165).

5 The parties have experimented with new ways of making contact with members or society at large. For instance, the Hungarian Socialist Party has organised seven party congresses in the current parliamentary cycle: May 2002, March 2003, March 2004, August 2004, October 2004, April 2005 and the latest one in mid-June 2005. Some other parties, such as FIDESZ, have organised pseudo-mobilisation (for example, 'national referendums' by the party, or 'civic circles' and street demonstrations) to give the impression that they are compensating for the lack of intra-party democracy and the considerable powers the party statutes have vested in the party leaders.

6 There was a very low turnout in ECE at the June 2004 elections to the EP. The average electoral participation was 28 per cent in the recently joined members compared to 47 per cent in the older established members. The percentages were 27.9, 21.2, 38.5, 28.2 and 20.0 in the Czech Republic, Poland, Hungary, Slovenia and Slovakia respectively. 


\section{External assistance for political contenders in transition states}

\section{Cautionary tales from the Balkans}

\section{Tom Gallagher}

After 1989, Eastern Europe was the scene of particularly intensive external efforts to promote democracy. It might even be possible to refer to a fourth democratic wave in which the stimulus for change was mainly external, unlike Huntington's pre-1989 third wave of democratisation, which was mainly triggered by internal developments (Huntington, 1991). The United States were to the fore in the external sponsorship of pluralist politics - eventually to be followed by the European Union as well as party political foundations in Germany and independent bodies such as the Open Society Foundation (OSF, or Soros Foundation).

The Soviet takeover of a belt of states from the Baltic to the Black Sea was crucial to the launch of the cold war in the second half of the 1940s. A lot of American energy, and, indeed, emotional commitment, was subsequently invested in ending Soviet control of its satellites. Eventually the apparent victory of the West seemed to pave the way for the region's political and economic institutions to be fundamentally refashioned. Broadly liberal values were promoted in a bid to replace authoritarian and collective systems of rule with ones based on open and competitive political and economic arrangements.

The nature and intensity of communist rule were far from uniform in the Soviet bloc. But in the Balkans the replacement of the traditional social system with one based on rigid one-party rule and forced industrialisation had usually been pursued with greater militancy and zeal than in the Central European 'People's Democracies', Poland, Czechoslovakia and Hungary (Gallagher, 2005b: 186). This meant Bulgaria, Romania and Albania lacked the internal resources necessary to move speedily in an unambiguously democratic direction. Yugoslavia was in a stronger position because of the pragmatic economic policies pursued under Marshall Tito until his death in 1980 , but this advantage was erased by the disastrous wave of internal conflict that tore apart this federal state in the 1990s. By the close of the 1990s external support for democracy appeared to be the only firm asset these states possessed as they attempted, in their economic and security arrangements, to become part of the community of Euro-Atlantic states. This chapter argues, mainly with reference to party 
assistance, but taking account of complementary support for civil society initiatives, that external intervention in these areas has not decisively strengthened the democratic process in the Balkans. Structural factors such as the uninhibited nature of power struggles in different localities and the limited social categories involved in emerging party activism make it difficult for new parties to work effectively with donors. Transparency, internal democracy, access for citizens and even respect for basic democratic rules have all too often been honoured in the breach, not the observance. Moreover, broadly contextual issues have hampered the rise of parties with a solid democratising ethos. The globalisation process has led to new patterns of dependence and subordination, leaving the Balkans at the margins of the European political economy, which is reflected in domestic political arrangements. The regionalisation process that the $\mathrm{EU}$ is championing has also contributed to a low-intensity democracy, with the oligarchic features of parties being strengthened by the way that EU assistance is formulated and delivered. There is evidence that the political conditionality attached to the release of funds by external donors is far less onerous than economic conditionality: inevitably the quality of party-led democracy suffers. The need to reform the state so that it is able to resist predatory attempts to colonise it or divert its resources has also been overlooked by the multilateral institutions (with the exception of post-2000 Bosnia), leading to harmful political effects.

The chapter will therefore argue that the approach of external donors to democracy promotion in the Balkans usually falls rather far short of what is needed in order to be able to contribute to the consolidation of democracy in the region.

\section{The Balkans enters the sights of democracy promoters}

Promoting democracy moved towards being a core element in US foreign policy from the early years of the Reagan presidency in the 1980s. The institutionalisation of the US democratisation drive was marked in 1984 by the founding of the NED, which by the end of the 1980s was overtaken by the USAID in size and significance as a democracy promotion actor. A series of programmes in Central America and parts of South America were designed to reinforce a strategy of containing radical leftist movements. The stress on repulsing communism, or at least its remnants, was carried over to the Balkans.

Across the region, the communist party, or more often its successor, remained the best-organised political force. It was usually prepared to modify or abandon its Marxist-Leninist doctrine while attempting to retain a near-monopoly of power. The party institutes attached to the two main US political parties became heavily involved in assisting new parties in the Balkans prepared to challenge the dominance of these post-communist 
forces. The IRI modified its partisan backing for anti-communist parties in developing countries that had been in the front line in the cold war, but applied it to parts of the disintegrating Soviet bloc where networks of power and influence, some with a clear-cut anti-Western outlook, appeared determined to hang on to power (Carothers, 1999: 144). Albania, Bulgaria and Romania witnessed intensive efforts to strengthen fledgling parties from both the IRI and the NDI. Technical assistance and training on campaign methods and institutional development of parties were prioritised. Considerable emphasis was placed on the electoral arena in order to guarantee free and fair elections that could result in a peaceful transfer of power. These forms of external assistance were extended to government institutions and civil society. Whereas there was wariness about promoting the concept of civil society in other countries, where 'people's power' was often seen as a preserve of the radical left, in Eastern Europe this was not a preoccupation of American donors. Civil society was viewed in Washington as a force that in some countries had played a key role in displacing communism and thwarting a neo-communist alternative (Carothers, 1999: 208). Civil society mobilisation in Bulgaria and Albania at different stages in their protracted transition processes was sometimes seen as having more potential to strengthen fragile democratic processes compared to orthodox political party developments. Accordingly, more funding was channelled into the civil society sector, especially during the Clinton presidency from 1992 to 2000 (Carothers, 1999: 204).

Fifteen years have now elapsed since the disappearance of single-party rule along Marxist-Leninist lines in the Balkan states of south-east Europe: Yugoslavia, Albania, Bulgaria and Romania. In that period of time, it has become increasingly apparent that international assistance to enable new parties to cope with the challenges of democratisation has not been very successful. What has happened in those fifteen years? Fukuyama's (1992) proclamation of a New World Order based on the triumph of liberal principles was shown to have a very shallow basis even in the heart of Europe. The emergence of a more just and democratic global order was foiled in the very neighbourhood that supposedly had witnessed a decisive victory for the forces ranged against the totalitarianism of the left. Yugoslavia, the largest state in the Balkans, was cold-bloodedly dismantled by a section of the ruling elite that sought to radically rebuild it around an ethno-nationalist core (Conversi, 2000). The Greater Serbia project of Slobodan Milošević, which was partially emulated by the Greater Croatia project of Franjo Tudjman, led to the deliberate unleashing of longburied rivalries or manufacturing of entirely new ones, in order to radically alter the human geography of what had been Yugoslavia (Gallagher, 2003, Chapters 3 and 4). The worldwide interconnectedness at the heart of the globalisation process was rendered mute. Finally, in 1995, the Atlantic democracies with the US to the fore intervened to impose a 
ceasefire in the Bosnian conflict (raging since 1992). The messy peace process that followed, and a more resolute, but poorly executed attempt a few years later to prevent a conflict in Kosovo reaching a similar bloody climax, showed how little enthusiasm there was for upholding a globalised approach to security even in Europe's heartland (Wheeler and Bellamy, 2005: 575).

Competitive parties in the Balkans, among whom the commitment to pluralist practices is genuine and not insincere, have a stupendously difficult task. The collapse of single-party states and the command economy has produced millions of social casualties. In certain war-affected parts of the former Yugoslavia, criminal groups have tasted power and been very difficult to displace. The plunder of the state and the wholesale theft of private goods in parts of Bosnia, Croatia and Kosovo resulted in a radical realignment of the social structure. Urban elites whose status and prosperity derived from their professional skills lost ground to individuals from a small town or rural background, who possessed little formal education but who did exceedingly well out of the war (Kaldor, 1998). With much of the existing middle class becoming trapped in poverty as state salaries failed to keep up with inflation and waves of sackings occurred, based on political or ethnic criteria, well-qualified and often liberal-minded people fled abroad to remake their lives.

The collapse of manufacturing industry across much of the region, either because of the effects of war and international sanctions against Serbia or because of its uncompetitive character, has had a destructive impact on the working class. A social group that was influential in West European (party) politics at least up to the 1980s faces marginalisation in the Balkans only a few years after the ending of political systems that were supposed to govern in its name.

The wars in the former Yugoslavia led to the erosion or collapse of central authority. Even Slobodan Milošević, the chief architect of Yugoslavia's destruction, soon lost control of forces that he had whipped up and armed in order to dismantle federal Yugoslavia and then reunite it around a Serbian core (following massive enforced population movements). The fragmentation of political power enabled warlords, criminals and corrupt businessmen to emerge as power-brokers across large parts of the fractured state.

To a lesser extent, and in different ways, the criminalisation of power was noticeable in those Balkan states that had formally remained at peace: Bulgaria, Albania and Romania (to which could be added Macedonia, the southernmost republic of the old Yugoslav federation). Programmes designed to overcome the defects of institutions such as the judiciary, vital for the functioning of a law-based society, had 'an artificial technical quality'(Carothers, 1997: 123). For a long time they would be devised without overmuch concern about the context in which these institutions existed. Which internal forces benefited from a corrupt or underperforming 
customs service, judiciary or prosecutor's office? How could the capacity of different state agencies to sabotage reform efforts be reduced? There indeed appeared to be few active reform constituencies in these countries and few political parties that appeared capable of being the nucleus of an effort at sustained democratisation.

\section{Western assumptions tested against Balkan realities}

Belated US intervention in the Bosnian conflict in 1995, when it appeared that Western geo-strategic interests were being threatened by its prolongation, provided another massive impetus towards the fragmentation of political power and its capture by new social formations. The 1995 Dayton Peace Agreement (DPA) provided for a weak central state overlaying ethnically based layers of authority, which was where real power resided (Gallagher, 2005b: chapter 6). There were two ethnically based entities. The Federation of Bosnia-Herzegovina represented an enforced union of the Bosniaks (or Muslims) and the Croats who, for the rest of 1990, operated a para-state known as Herceg-Bosna. The federation was further weakened by the creation of ten cantons. They soon became centres of economic power as massive amounts of humanitarian aid flowed into Bosnia to begin post-war reconstruction. The second declared entity was the Republic of Srpska (RS). The breakaway Serbian statelet, which had waged a savage war against its ethnic Muslim rivals, was allowed to remain in existence and indeed retain its own separate army.

An international administration was to govern in partnership with local political forces. This hastily conceived experiment in political engineering was based on the assumption that the more complicated and multilayered the elected institutions were, the likelier it was that previously implacable rivals would discover the need to cooperate with one another. Dayton's architects thought that early elections and the devolution of power to the entities, and further down still to the cantons and the municipalities, might provide the basis for trans-ethnic co-operation to get under way. Instead, all the incentives were for the leaders of the three national groups to build three different polities and to ignore or weaken the central state (Knaus and Whyte, 2004).

However, the belated US intervention in Bosnia was the Clinton administration's most ambitious international undertaking, and the credibility of externally led efforts to reconstitute a state and its society after unremitting internal conflict depended on the venture enjoying success. But this undertaking contained serious flaws often noticeable in more routine efforts to sponsor political progress in places that had avoided the meltdown seen in Bosnia. There was a fixation with achieving short-term targets and, indeed, concluding the task of political reconstruction within an incredibly brief timescale, US forces being originally due to withdraw by the end of 1997. The need to take account of underlying 'power factors' 
was overlooked. So was the importance of building state institutions able to enforce their authority on recalcitrant groups opposed to the normalisation of politics and inter-societal relations. Breaking up the leviathan former communist state was seen as an overriding priority in most former communist countries, but donors gave little thought to how to restore its competence and legitimacy, especially in the face of criminal groups, sometimes benefiting from ill-thought-out neo-liberal policies that were ready to challenge its remaining authority.

David Harland, a top United Nations official in Bosnia during the mid1990s (later responsible for drawing up the UN's report on the Srebrenica massacre of 1995), wrote 'Bosnia has taught much to all of us about how not to implement a peace agreement' (International Herald Tribune, 27 January 2004). The Dayton experiment threw into sharp relief some of the doubtful core assumptions held by those involved in exporting liberal political forms to unpropitious settings: (1) that overcoming strong internal barriers to progress and the entrenched interests behind them need not be factored into the democratisation agenda; (2) that elections are the vital rite of passage in the transition from conflict, tyranny or both towards political stability; they comprise a series of end points: participation of citizens in political decision-making; the establishment of rules for assessing political change; peaceful competition between previously entrenched rivals; and the formal move towards a stable constitutional order. The September 1996 Bosnian elections resulted in the triumph of the forces of ethno-nationalism in each of the three main ethnic groups, arguably giving them far more legitimacy than they had previously exercised during the years of outright warfare.

The NATO-led UN mission in Bosnia after 1995 aimed to prepare Bosnia for international statehood by building trust and a willingness to co-operate among the different ethnic groups. Instead, ultra-nationalist forces were given incredible incentives to refine their separatist agendas, thanks to unwise pseudo-reforms. The most glaring one was a deeply inappropriate form of privatisation imposed from 1998 onwards, admitted as such by Haris Silajdžić, the wartime Prime Minister of Bosnia. Privatisation legislation was hastily drawn up by USAID with US Department of the Treasury influence. Under a firmly neo-liberal economic agenda, it was assumed that privatisation would stimulate the economy and create accelerating social benefits. The approach of US advisers with little direct knowledge of Bosnia made this a virtual impossibility irrespective of whatever merits a neo-liberal agenda might have had. The USAID plan allowed for 12 privatisation agencies, one for the RS, one for the Federation and another for each of its cantons. Besides the opportunities for corruption, this unwieldy approach offered politicians the chance to confirm the effects of ethnic cleansing by means of ethnically exclusive privatisations.

Local economies remained under mono-ethnic control as privatisation gathered pace. The need to build up state competence was overlooked in 
an almost religious belief that deregulation would promote economic and political 'normalisation'. Instead, local nationalist elites quickly gained control of socially owned assets. Jobs and other economic goods were distributed by powerful magnates to favoured supporters, enhancing patronclient relations. The informal economy started to thrive as the socially owned one declined in the face of accelerating de-industrialisation. This enabled ethno-political leaders to strengthen their political hold over many Bosnians even as inter-ethnic tensions slowly began to recede (Pugh, 2004: 55).

Launching hasty and often ill-thought-out neo-liberal measures while the strengthening of the state was neglected hardly served to stabilise a territory such as Bosnia, which was still reeling from conflict. It seemed to confirm the assertion of those critics of democracy promotion who see lying behind it a goal of aggressively spreading free market economics in post-communist settings. One scholar, Vasile Fouskas, was even moved to claim that in 1999, the US insistence on the introduction of free market principles in Serbia lay behind its confrontation with Milošević at that time (Fouskas, 2003: 46). But few US or other foreign private investors would be drawn in even as the timescale of Western involvement in statebuilding extended beyond 2000 .

Misconceived policies emanating from the international administration and the chief national players shaping the peace-building strategy in Bosnia blighted attempts to strengthen the capacity and credibility of Westernleaning parties in Bosnia. They were pursued by democracy assistance experts attached to the OSCE and the foundations linked to German and US parties. For Britain's WFD, too, the Balkans were a primary area of concern, from the late 1990s. The assumption that a strengthening of democratic processes could prevent or reduce the likelihood of a return to conflict guided its programmes. Assistance was given to multi-ethnic parties in Bosnia in order to strengthen their capacity to successfully take part in elections. (Westminster Foundation for Democracy, 2005: 6) In an effort to promote a non-national political community, attempts were made to bring parties and NGOs with similar objectives closer together, but there was resistance on the part of Bosnia's Social Democratic Party, the principal reformist contender, towards working on joint projects with the NGO sector (River Path Associates, 2005: Vol. 1: 58). Whatever the quality of the WFD's programmes, their impact was likely to be limited as long as the international administration and the chief national players attempting to strengthen Bosnia's opposition appeared to lack a coherent peace-building strategy. From the late 1990s there was a belated awareness of the need to strengthen the authority of the central state and take back powers from the entities and cantons and municipalities.

In contrast to Bosnia, external assistance for political parties has been less noticeable in Kosovo, which became a de facto UN protectorate in 
June 1999; perhaps the strongly nationalist characteristics of the main political forces proved too much of a disincentive. But the WFD was prepared to work with the most nationalistic of Kosovo's Albanian parties, the Democratic Party of Kosovo (PDK) and the Association for the Future of Kosovo (AAK). It claimed most of the credit for having 'successfully brought' them into the mainstream democratic process' (Westminster Foundation for Democracy, 2005: 6).

Turning to Romania and Bulgaria, Carothers (1999: 311) remarked that both countries may be cases in which Western democratic aid has had 'real weight', but in fact the results appeared meagre for much of the 1990s. In Romania, substantial US sponsorship of groups on the centreright opposed to the still influential post-communists failed to stimulate the emergence of modern professional parties able to bear the responsibilities of government, as shown when they were in government from 1996 to 2000. Bulgaria received the greatest share of democracy aid for the whole of Eastern Europe from the US under the 1991 Support for East European Democracy Act (SEED) but, after several years of political stalemate, the Bulgarian Socialists (ex-communists) were returned with an overall majority in 1995. A period of chronic misrule that led to the systematic looting of state resources culminated in mass demonstrations in 1996-7, leading to the collapse of this government. In Albania, an unpopular government increasingly intolerant of opposition was swept from office by a popular revolt following hotly disputed elections and the collapse of a pyramid savings bank that absorbed most of society's private savings. This led to the collapse of state institutions in 1997 and widespread anarchy. The IRI had given high-profile backing to Prime Minister Sali Berisha's Democratic Party as indeed had several ruling parties on the right in Western Europe.

Western disarray had first surfaced after the parliamentary elections of 26 May 1996. Appalled at the extent of vote-rigging and intimidation, a number of observers from the OSCE delegation, monitoring the conduct of elections, denounced them as fundamentally flawed. The OSCE went on to produce a heavily critical report while that of the Council of Europe's monitors was much milder. As a result, opposition parties used the OSCE findings to justify their parliamentary boycott while Berisha's Democrats quoted the report of the Council of Europe to uphold their landslide victory. The Italian and German ambassadors were reported to have exercised pressure on the Swiss-led OSCE team not to invalidate the 1996 elections 'and to bury their reports in the drawers of realpolitik' (The Guardian, 14 March 1997).

The example of Berisha's Albania, and also Croatia (under President Tudjman's tight control from 1991 to 1999), revealed centre-right parties with an approach to monopolising power and public goods not dissimilar to that of the former communist parties. Capturing the state and diverting 


\section{Tom Gallagher}

its resources to a narrow retinue of supporters and business allies sometimes appeared to transcend the political spectrum. Western parties and others seeking to strengthen the parties' democratic capacity often failed to make much impact in such circumstances. Assumptions and expectations were often greatly at variance with the reality of inner party life and behaviour in the Balkans when encountered on the ground.

\section{Unintended consequences flow from the EU's deepening engagement}

From 2000, the US under a Republican administration preoccupied with international terrorism and the Middle East has grown increasingly detached from the Balkans. The EU has replaced the US as the main international actor across the whole region, acquiring a new Common Foreign and Security Policy as it seeks to supplant the conventional authority of the nation states belonging to it, in important respects. The promotion of peace, security and democratic institutions in adjacent zones are cornerstones of this foreign policy. It is widely recognised that the success or failure of this ambitious transnational development will, in no small way, depend on how effectively it can promote reform in the Balkans when drawing the region closer to European institutions.

By 2005 the EU had assumed control over both civil and military aspects of the international mission to create a Bosnian state fit for both EU and North Atlantic Treaty Organisation (NATO) membership. It has been involved for a rather longer period with trying to prepare those Balkan states that remained at peace, particularly Bulgaria and Romania, to face the rigours of EU membership, the main gateway for their integration with the global economy. But some of the changes promoted by the EU have also contributed to the fragmentation of political authority noticed elsewhere in the region, impeding the emergence of strong central parties with a clear sense of direction.

Romania, the largest country in the region following Yugoslavia's demise, has proven to be one of the biggest challenges for the EU. In a move designed to strengthen its bid for EU membership, the centrist coalition ruling Romania from 1996 to 2000 transferred power and resources to the localities, a move unprecedented in Romanian history. A law on local public finance introduced in January 1999 enabled 50 per cent of income tax revenue to go to local government as well as a large share of the revenues earned by the local branches of the national privatisation agency (Gallagher, 2005a: 239). The EU regards decentralisation as a vital prerequisite particularly in previously heavily centralised states if they are to benefit effectively from membership. But not all the consequences appear to have been anticipated by EU officials. Capturing power at the local level has become a major priority for competing parties because of the 
resources now located there. Enjoying most success in this regard has been the successor to the communist party, the Social Democratic Party (PSD), in office from 1990 to 2004 and for all but four years in the late 1990s. Until it narrowly failed to be re-elected in 2004, its monopolistic approach and harassment of the local media and local business forces not subservient to it caused numerous anxieties for the EU (Gallagher, 2005a: Chapters 10 and 11).

Another source of concern has been the fate of pre-accession funds meant to modernise the state and enable it to compete effectively with existing EU members. A large component has been channelled through regional bodies especially created to quicken the pace of support for the Romania infrastructure, bypassing unwieldy and often partisan central ministries. But the regionalisation process has created new power centres greatly altering the character of the PSD. Authority has swung towards regional barons who have grown powerful through their ability to siphon off regional funds for their own private use (Gallagher, 2005a: 313-14). The extent to which the centre of gravity has moved towards local and regional chieftains was shown in April 2005 when their votes displaced the party's founder Ion Iliescu - hitherto seen as enjoying an unassailable hold over the party. The regional barons in their turn have caused concern at the EU because of their contempt for conduct necessary for a modicum of good governance. But it was the EU's own strategy that contributed to this shift, altering the balance of power inside Romania's main party and, in some ways, making it more difficult for the PSD to benefit from outside advice and assistance designed to strengthen pluralist tendencies within the party.

Thus a key part of the regionalisation process that Romania has been subjected to since entry talks began in 1999 has had unintended consequences. Injections of economic and technical assistance, instead of spreading liberal values, enabled the dominant party to tighten its control over different layers of state authority and weaken competitors. Even with the election of a variegated coalition of the PSD's opponents in 2004, the party retains control of its local fiefdoms, not least because of the EU money that flows into the regional authorities that it mainly dominates. The Romanian case suggests that unless regional assistance is rethought in Brussels, then a strengthening of democratic processes in the Balkans will not necessarily be one of the outcomes of growing interconnectedness between Western Europe and its Balkan neighbours.

\section{The unhealthy state of donor parties}

The condition of donor parties and their standing in their home countries has often raised legitimate concerns about their ability to be effective sponsors of democratisation in regions struggling to escape from arbitrary 


\section{Tom Gallagher}

rule, chronic underdevelopment and misuse of resources by a privileged few. Parties from consolidated democracies in Western Europe, and to a lesser extent in North America, have experienced mounting difficulties and have changed in character during this period. Their membership has often shrunk, contacts with key social groups have frayed, and they have often fallen under the sway of special interests, particularly in the business world. Their overall credibility at home has often declined. The characteristics in terms of separate programmes, distinctive ideological positions and mobilising techniques that might once have distinguished parties have been greatly eroded in the post-cold war era. In Britain there is no better illustration of this than Power to the People, which found that the level of alienation felt towards politicians and the main parties was extremely high and widespread: 'Few aspects of the political system investigated by Power received more hostile comment than the main political parties' (Power Commission, 2006: 181). At best the main parties were judged to be 'failing in the basic function of connecting governed and the governors, and, at worst, are serious obstacles to democratic engagement'.

So it is probably not unfair to say that West European parties from the Socialist/Social Democratic, Liberal, Conservative and Christian Democratic families find it difficult to offer meaningful support to democratising forces in a region with an enormous range of problems that defy easy solutions. Their own families are increasingly dysfunctional, some major parties have disappeared (Italian Christian Democrats) or faced serious electoral reverses (British Conservatives, French Socialists, German Social Democrats), or have had to radically redefine themselves in order to remain viable (British Labour and Conservative Parties). Struggling to retain respect in their own increasingly disgruntled societies, it is perhaps bordering on the utopian to expect tired parties to have the means to reinforce Balkan parties and point them in a direction that results in sustained attempts to make an experiment in democratisation work.

\section{The temptation of regime change}

It is hardly surprising that a huge gulf often exits between the parties and the Balkan societies in which they operate given their oligarchic features. Support by the IRI for Romania's historic parties trying to supplant the post-communist PSD in the early 1990s failed to transform the 'club' atmosphere of political parties based around several prominent individuals and their retinues. They were 'unwilling to learn from outsiders', but nor were their sponsors engaged in an effort designed to change the nature of these parties through, for instance, the strengthening of their representative function. The US Republicans wished to dislodge the post-communist Ion Iliescu from office. Their concern was with making the opposition appear electable by strengthening their professionalism in elections, media 
appearances and party organisation. Nothing more ambitious than strengthening the technical efficiency of the Romanian centre-right opposition appeared to be required (Carothers, 1996: 39-42).

Achieving regime change was also the impetus behind the concentrated assistance given to Serbia's coalition of 18 opposition parties known as the Democratic Opposition of Serbia (DOS). After the confrontation between NATO and Milošević in 1999, US Secretary of State Madeleine Albright had told her officials that she fervently wished Milošević gone from power by the time her term of office ended in 2002. ${ }^{1}$ Some US\$30 million from US sources went to the opposition in the pre-election period. It was used to purchase cell-phones and computers for DOS's leadership and recruit and train an army of 20,000 election monitors. External backing also enabled Otpor, a pro-democracy youth movement, to launch a sophisticated marketing campaign with posters, badges and T-shirts. By the eve of the September 2000 elections, it consisted of 20,000 activists organised into 'action teams' in 120 towns across Serbia (Collin, 2001: 208). Otpor's rallying-cry was, 'He's finished!' This investment paid off: Milošević was ousted by popular unrest, after a failed attempt at election fraud. Heavy Western backing for the hitherto weak and fragmented Serbian opposition forces in 2000 was the most visible and spectacularly effective example of international assistance for parties in states struggling to democratise. It was seen as a dry run for an even more sophisticated and extensive assistance operation for the Ukrainian opposition, which prevailed against a post-communist oligarchy following the disputed elections there in November 2004. But international assistance did not appear to have a lasting impact on the Serbian parties. They remained in the main coterie parties keen to benefit from their access to state power and neglectful of developing any representative function that would narrow the chasm between state and society. The need for the governing parties to finance election campaigns gave some of the power-brokers from the Milošević era (still active in the underground economy) significant scope to prolong their influence. Following the assassination of the Prime Minister of Serbia Zorin Djindjić in 2003, the assumption that a clear dividing line existed between the 'reformers' of DOS and the nationalists, racketeers and communist-orientated figures who had dominated Serbia since the late 1980s became increasingly untenable. In fact the battle lines have become extremely blurred. Much of Serbian politics today revolves around securing the spoils of office rather than championing specific political values or projects (Gallagher, 2005b: Chapter 5).

The Romanian and Serbian parties that received Western training and financial support in the end were the victims of their own shortcomings and the punishing political environments in which they had to operate. But they faced severe international pressure that lessened their chances of maintaining a reformist momentum in the face of hostility from local 


\section{Tom Gallagher}

forces deeply hostile to genuine political pluralism. In Romania, struggling reformers saw their popularity vanish in the late 1990s partly owing to the need to bow to IMF demands for higher taxes and rapid privatisation, changes fully endorsed by the EU (Gallagher, 2005a: 217-18, 222). In Serbia after 2000, strong Western pressure to deliver top suspects to the United Nations Tribunal for the Former Yugoslavia in The Hague greatly reduced the room to manoeuvre of the embattled Zorin Djindjić. Thus, neo-liberal policies or adherence to international human rights norms - among the most contested aspects of globalisation adversely affected the ability of reformers to consolidate their authority. They were caught between the competing pressures of delivering goods and services for their citizens and slimming down their states in order to compete in a global marketplace.

\section{A loveless duo: civil society and political parties}

The very limited successes enjoyed by external donors in attempting to groom Balkan parties that could play a central role in the democratisation process have encouraged them to redouble their efforts in the civil society field. Civil society organisations with a strongly pro-democratic orientation have continued to receive much external assistance. The policyorientated and service-delivery NGOs with a reformist agenda often appear to exhibit a greater level of professionalism and transparency than political parties. Donors often found it easier to wield influence over them, especially because they were not answerable to public opinion or other important national constituencies. But policy-orientated NGOs adept at securing international funding were not always successful in embodying democratic values such as transparent governance and accountable leadership (Quigley, 2000: 206). While usually responsive to the bureaucratic needs and world view of donors, they could easily lose touch with important sections of society (Ottoway, 2000: 13; Quigley, 2000: 210). Many successful NGO participants in the Balkans were drawn to international careers and seemed inclined to detach themselves from the public arenas of their home countries. They may intuitively realise that the civil society model pushed by US donors, and also the EU - professional organisations sustained by a large middle-class and a corporate world with a tradition of philanthropy - is unlikely rapidly to take root at home (Carothers, 1999: 221). The lure of a career in international civil assistance or development is greater than the attraction of moving over to regular politics. Relations between parties and civil society groups are often notoriously poor. Democracy promoters have started to give more thought to trying to bridge the gulf (Gershman, 2004: 28-32), but the Balkans shows it is far from easy. Parties react with undisguised fury towards the claims of unelected individuals who possess a lofty moral 
purpose 'and whose closest allies are often sections of the media who are the main critics of the parties' (Furedi, 2005: 111, 116).

It is thus extremely hard for civil society bodies to carve out permanent political influence. Sometimes it is felt that this can only be done by entering the electoral arena as a direct competitor for office. In Serbia Otpor tried and failed to do this and obtained a derisory result in 2003, even when the reputation of parties once known for their reformist goals was at its nadir. The same had happened in Romania a decade earlier when a large segment of its then best-known NGO, the Civic Alliance, formed its own party before suffering dissension and eventually being absorbed by another party. However, in Bulgaria the Centre for Liberal Strategies has exercised the same watchdog role over an unconsolidated democratic system as the Romanian Academic Society (SAR) and ProDemocratia have performed in Romania. These particular NGOs have displayed greater staying-power and coherence about their aims and objectives than perhaps any of the pro-reform political parties. For Romania, 2003-04 was an anxious period when the country at times appeared to be on the verge of becoming 'a choiceless democracy': the opposition was completely submerged by a dominant party fully in control of all of the levers of state power. But the PSD unexpectedly lost office at the end of 2004. In October 2004, 12 of the leading advocacy NGOs in the country joined forces to form a Coalition for a Clean Parliament (CCP). It documented the cases of 222 parliamentary candidates from the ranks of the major parties who were judged to be unsuitable to hold high elected office. Politicians were faulted if they had been enmeshed with the communist system and the Securitate (police and intelligence), if they had acquired fortunes incommensurate with their declared private assets, if they had profited from controversial privatisations or if they were involved with private firms that had secured lucrative contracts with public utilities or state-owned firms (Stan, 2005). So-called 'corruption' bulletins were drawn up for each constituency especially where, in the absence of an independent local media, it was difficult for voters to obtain information on the candidates' background. The Democratic Party (PD) largely complied with the request to stand down tainted candidates. But members of the ruling PSD took out law suits against the CCP. Local activists fabricated its bulletins in order to indict opponents of the PSD. Traian Băsescu, PD's leader, became President after a narrow victory and appointed a non-PSD government, one of whose best-known figures was the head of the main human rights NGO in Romania, Monica Macovei. As minister of justice her challenge is to overhaul a justice system that has become a byword for corruption, threatening Romania's chances of joining the EU on schedule in 2007.

West European parties remained on the sidelines even in the face of allegations of fraud in the parliamentary and presidential elections of 


\section{Tom Gallagher}

28 November 2004. The Socialist International endorsed the ruling PSD, its head António Guterres (appointed head of the United Nations High Commission for Refugees in 2005) actually visiting the country during the election campaign to publicly support the ruling party. The rival EPP of centre-right parties in the European Parliament sent a delegation to Romania in May 2005 to determine which parties could join the grouping once Romania started to send elected representatives to the EP. This started an unseemly dash among Romanian parties to change their names and programmes in order to gain coveted membership in this parliamentary club. But once inside the EPP it was not expected that they would change to any meaningful extent nor did it appear that the EPP expected them to improve their act (other than disavow extremist positions). In their attitude to aspirant parties, the main leftist, centrist and conservative blocs in the EP all too often have behaved like Balkan parties themselves at the start of their lives seeking to quickly acquire activists without enquiring too closely about their fitness to represent the party. If these club arrangements amount to the regionalisation of party politics as the Balkans draws closer to eventual EU membership, it seems unlikely that the Western mentors have the aptitude or inclination to establish new norms of behaviour among their Balkan associates.

By contrast, parties in kin states such as Croatia and Serbia have provided more concentrated assistance to parties dominated by their co-ethnics in neighbouring territories such as Bosnia and Kosovo (although keeping alive territorial ambitions may be the main impulse for such solidarity). Also, parties have sometimes enjoyed more effective patronage from émigré groups. This certainly applies to right-wing nationalist ones that have been in office in Croatia for most of the time since 1991 and less often in Macedonia. The possibility of transnational criminal groups showing more expertise and flair than conventional purveyors of assistance in influencing parties they hope will defend their illicit interests cannot be ruled out.

\section{Conclusion}

It is often difficult for international assistance for party development channelled through foundations and institutes (with or without a link to Western parties) to have a positive impact in the Balkans. The region is experiencing major difficulties in establishing the basis for smoothly functioning democracies. This stems from a variety of factors: the damaging legacy of hard-line forms of communism associated with major policy failures, especially in the economic realm; the collapse of Yugoslavia, previously the largest state in the region, into dissolution and warfare; and the effects of globalisation on the political economy of the region. It is far from clear if the absorption of Bulgaria, Romania and perhaps 
eventually several states in the Western Balkans into the EU will provide the impetus for economic recovery and political stability. This may be because the integration process was designed for states that had a different social and economic profile from those found in the region: a large service sector, a growing middle-class and significant levels of urbanisation and public administrations able to absorb aid and redesign their laws to fit in with EU norms.

The regionalisation process that Romania, Bulgaria, Albania and several other Balkan states are now part of appears likely to initiate a new pattern of dependence and subordination, with the EU replacing the pre-1989 Soviet Union as the chief regional hegemon. By 2005, EU-based firms had bought up nearly all of the strategic sectors of the Romanian economy. The vested interests of West European economic groups in seeing their investments protected by Romania becoming a full member by 2008 was the chief guarantee that its accession would not be frozen because of persistent failures to reform. The chronic weakness of the state is emerging as a drawback hampering the consolidation of democracy in the region. Foreign donors were all too ready to promote the dismantling of the Marxist-Leninist state without seeing the need to replace it with a state able to regulate the private sector and shield citizens from unscrupulous forces benefiting from the onset of untrammelled capitalism. The mistake was noticed in Bosnia five years into a dysfunctional peace process, and steps were taken to strengthen central institutions. Where thought has been given to the matter, it appears that both the US and the EU prefer a state model that is suitable for rapid economic liberalisation but that is unable to promote democratisation allied to a strong sense of citizenship. None of the Western nations promoting radical economic liberalisation along with competitive democracy ever subjected themselves to the experiment that they have urged upon post-communist and a range of developing countries (Chua, 2003: 13). Strong internal backing for democracy only emerged gradually in today's mature democracies. The international impetus is likely to remain weak in the Balkans as long as competitive politics is indelibly associated with economic suffering by millions of voters. External leverage is ineffective without strong domestic parties that display a capacity to rule along with a vested interest in consolidating a robust democracy. Ruling parties such as the Romanian PSD from 2000 to 2004 have noticed that political conditionality imposed by the EU and the US is usually less rigorous than economic conditionality or the commitment to the global war on terrorism (Gallagher, 2004: 12-13). Sanctions from the West for blocking reform of the judiciary, harassing the independent media and impeding effective anti-corruption measures were very light indeed in 2003-04 when Romania joined NATO and made significant progressive with its EU bid. This suggests that Western promoters of democracy were ready to endorse the age-old Romanian 


\section{Tom Gallagher}

syndrome of form fara fond (literally form without content), which has been widely seen for over a century as a metaphor for the country's failure to successfully modernise.

Perhaps party-based organisations (and associated institutes and foundations) in the Atlantic democracies that see a role for themselves in the Balkans can be most useful if they try to exert leverage in their own capitals to prevent the imposition of policies that undermine the reformists and prevent the transition process reaching successful completion, with a real likelihood of periodic reversal to authoritarian practices. They might ask if the fragmentation of power which has been the direct outcome of the West's engagement in the region, as shown by the 1995 Dayton Agreement in Bosnia, the promotion of a slimmed down state through privatisation, and the EU's accession process, leaves any point in backing parties that wish to be strong national players. With a weakened central state in the Balkans, it is often hard to see such parties emerging.

But if they are involved, there are elementary rules to be followed in order not to discredit international assistance. Assistance should not confer legitimacy on parties without proof of commitment to democratic practices and goals. It should not base programmes on the success of a particular individual, nor get involved in internecine party conflicts. Nor should anyone relax vigilance over the democratic process just because local ruling parties are prepared to grant large infrastructure projects to firms that are among their own principal donors. The fact that well-known parties in Western Europe have found themselves in such a situation raises real doubts as to whether they still have the commitment as well as the skills and expertise to be of service to parties in the Balkans attempting to make democratic politics work.

Given the fact that so many parties are in difficulties in their home environments, it is perhaps worth asking whether they should review the nature of their democracy promotion work abroad and search for alternatives. This is not to question the validity of the undertaking but rather to suggest that there are moments when parties might delegate the task of democracy assistance to non-partisan cross-party formations in their home countries. They would be more likely to employ a long-term focus and be less swayed by political expediency. The case for saying that actively encouraging the implantation of democracy in adjacent regions in fact strengthens the security of democratic strongholds such as WestCentral Europe remains strong. But the way that democracy promotion has often been linked with drastic economic measures that erode popular respect for pluralism has often opened up a dangerous gulf between electorates and fledgling party elites. Criminal groups have sometimes profited immensely from disenchantment with democracy. Their rise has obvious implications for the security of West European societies not to mention their own domestic ones. The Atlantic democracies should not abandon 
attempts to strengthen democracy in their immediate neighbourhoods, but much greater self-awareness is needed about what can be done and how best it can be carried out. Certainly, there is a great need for parties and other bodies involved in democracy promotion to ponder the lessons of the past 15 years in order to see how they can do better in the future.

\section{Note}

1 The Fall of Milošević, Part 3 (Brook Lapping productions, BBC 2, 2001). 


\title{
7 Globalisation and party transformation
}

\author{
Turkey's Justice and Development \\ Party in perspective
}

\section{Ziya Öniş}

\section{Introduction}

There is no doubt that Turkey's political system has undergone transformation in recent years partly as a result of the increasingly strong signals provided by the European Union (EU) and a more credible set of incentives relating to eventual full membership of the EU. However, it is not simply external actors alone but a complex interplay of domestic and external influences that have shaped this process of transformation, which in many ways remains an ongoing and incomplete process. This chapter has two interrelated objectives. The first goal is to highlight the paradoxical role of the Justice and Development Party (the AKP), a party with Islamist roots, in Turkey's recent transformation and Europeanisation. The second is to use recent Turkish experience to illuminate a broader question concerning the possibilities of transforming an Islamist political movement into a party that embraces the norms of liberal democracy. A central claim in this context is that although such a transformation is clearly possible and the norms of liberal democracy can be firmly entrenched in a predominantly Muslim society, this outcome in Turkey is context-specific, and is conditional upon the co-existence and the interplay over time of several favourable internal and external processes.

What is interesting from a comparative perspective is that unlike some of the countries included in this book, direct international assistance or promotion aimed at transforming key political parties has not been a major aspect of Turkish experience. International democracy promotion efforts have by and large been directed towards civil society organisations instead. The links between Turkey's main political parties and their foreign counterparts have also been relatively weak. Nevertheless, the process of globalisation has had a dramatic impact in terms of transforming one major party, the Justice and Development Party (AKP). In retrospect, the process of globalisation has contributed to this through three distinct sets of influences. First, it created a group of winners in economic terms, and this provided an opportunity for the party leadership 
to construct a broad inter-class coalition of both winners and losers, offering widespread electoral appeal. Second, the major crises of financial globalisation that Turkey experienced in 2000-01, which resulted in a massive collapse of output (with negative economic growth of -7.4 per cent in 2001) and which was accompanied by even more rigorous IMF conditions in terms of fiscal disciplines and regulatory reforms, helped to discredit the established parties on both the left and right of the political spectrum. This created political space for the AKP to capitalise upon. Third, the regional context of globalisation, namely the prospect of EU membership, has also played a particularly favourable role both in terms of transforming the party and boosting its electoral fortunes. Turkey's attempts to engage with globalisation through deeper integration with the EU have opened up an opportunity space for moderate Islamist politics, providing a source of protection against the secularist ideology of the state elites. At the same time, it has created a clear boundary for the range of permissible politics in the Turkish context, given the strong consensus in the EU on a secular constitutional order and, hence, the antipathy towards any signs of religious fundamentalism or fundamentalist politics in general.

\section{From moderate Islamists to 'Muslim democrats': the historical roots of the recent transformation}

The question of whether Political Islam is compatible with liberal democracy has considerable practical relevance not only for societies with Muslim populations but also for the future of the international economic and political order, particularly in the post $9 / 11$ global context. The fact that most of the countries in the Middle East and Islamic world more generally are ruled by authoritarian regimes and have been rather impervious to the kind of democratic currents affecting much of Latin America, Eastern Europe and East Asia following the end of the cold war also appeared to raise fundamental questions about the compatibility of Political Islam and liberal democracy. Turkey as a secular and democratic state with a predominantly Muslim population appeared to be a unique case in the Islamic world. Nevertheless, in the past Turkey's own democratic deficits limited its ability to offer a role model of change that would inspire political reform in Arab or other Muslim societies. More recently, however, Turkey's own political and economic transformation has helped raise the credibility and the international appeal of the Turkish experience.

Given the increasing international relevance of the Turkish experience, then, what are some of the key lessons that can be derived from this particular national and historical context? Certainly, one of them is that a secular political order is a precondition for liberal democracy. Liberal democracy cannot take root in a Muslim society without a strong commitment on the part of the political elites to the principle of a secular political 


\section{Ziya Öniş}

order and firm constitutional safeguards to prevent a violation of the secular character of the state. In spite of its limitations, one of the achievements of the Kemalist state founded by Kemal Ataturk in the 1920s has been to prevent the alternative of an 'Islamic state' (based on the Islamic Law) right from the beginning. The process of top-down implementation of the secularist ideology has also triggered a process of long-term social and political change. As a consequence, even the most authoritarianlooking versions of Political Islam in Turkey, such as the Welfare Party (the RP) in the 1990s were politically moderate by the standards of other Muslim societies. The goal of establishing an Islamic state has enjoyed only very marginal political support among the society at large. ${ }^{1}$

Yet another striking lesson is the long-term impact of the democratisation process on the behaviour of key political actors. Democratisation over time necessarily involves a learning process, and Islamists in Turkey have not been immune to this process. ${ }^{2}$ Indeed, scholars of Christian democracy in Western Europe have identified a similar learning process, whereby a largely authoritarian political movement has become transformed and has progressively embraced liberal democratic norms in the process of trying to construct broad electoral coalitions within the boundaries of parliamentary democracy (Kalyvas, 1996). Islamist political actors have also experienced a similar and often painful learning experience, which increasingly altered their basic perception of what was permissible in a democratic environment given the domestic and external constraints. What is interesting is that this learning process helped to instigate a virtuous circle whereby the Islamists learned not simply how to respond to democratisation in a reactive fashion but how to become a proactive force contributing to the process of further democratic deepening.

A third major lesson of the Turkish experience is the importance of an economic transformation that helps to produce a substantial middle class of entrepreneurs and educated professionals. If Political Islam is primarily a movement oriented towards mobilising the interests of the underclass of urban marginals and rural poor - the so-called losers of globalisation - then it is more likely to adopt a radical posture. If, in contrast, Political Islam is a movement based on a cross-class electoral coalition that includes a significant proportion of winners of globalisation, then it is more likely to take a more moderate direction. Clearly, the Turkish experience of economic development and more specifically the process of neo-liberal economic restructuring over the past two decades have helped develop a kind of conservative middle class or bourgeoisie that represents a significant moderating influence. Moving in a moderate direction and accommodating the precepts of a secular regime do not necessarily mean, however, that the norms of liberal democracy will be embraced. Certainly, Malaysia's flourishing bourgeoisie, for example, has 
been making a major contribution to economic development there without undermining the authoritarian political foundations of the existing regime. So the rise of an economically successful and influential middle class could be considered as a necessary but not a sufficient condition for the entrenchment of liberal democracy.

Another important lesson concerns the role of the intellectuals and civil society organisations. There is no doubt that civil society started to flourish in Turkey during the 1990s, and a wide variety of groups are now beginning to voice claims against the limitations of the current political order. Similarly, intellectuals from both the 'secularist' and 'Islamist' components of society have emerged as notable sources of criticism for the existing democratic order. Hence, democratisation in Turkey in the 1990s, especially, is strongly rooted in the domestic sphere; and pressures have been building from below for the transformation of the Turkish state towards a more democratic regime. ${ }^{3}$

There is no doubt also that the EU anchor has been extremely important in terms of helping to soften the underlying secular versus Islam divide in Turkish society. In this context, one should emphasise both the longterm impact of Europeanisation and Westernisation on Turkish democracy and the more recent impact of stronger signals in the direction of full membership, which have dramatically altered the incentive structure for key political actors and have helped to reshape the Islamists more than anybody else in the process. However, the very significance of this point raises a question mark concerning the broader applicability of the Turkish experience to the Arab Middle East, for the EU is unlikely ever to offer the possibility of full membership to the states in that region.

Finally, one should emphasise the role of leadership in helping to transform the nature of Islamist politics in Turkey. Structural incentives generated through globalisation and potential EU membership constitute important channels for political change. Nevertheless, the ability of key political actors to respond and capitalise on these incentives is also critical. In this regard Prime Minister Recep Tayyip Erdoğan and Abdullah Gül, the Foreign Minister, have been very instrumental. As well as currently occupying leadership positions in the AKP, they had previously been important figures in the Welfare Party (RP), and the FP establishments. They have played a central role in the transformation process by instigating the intra-party debate within the FP, which succeeded the RP in 1997, that culminated in the splitting up of that party and the creation of the AKP. The role of leadership in the transformation process becomes all the more striking when compared with the position of the main opposition party, the Republican People's Party (CHP), which through its own leadership failures was unable to capitalise on the opportunities provided by the new external environment. 


\section{Ziya Öniş}

\section{Accounting for the transformation: the interplay of domestic and external dynamics}

The Islamist movement in Turkey has been radically transformed over the course of the past decade. Table 7.1 clearly illustrates this by highlighting the profound differences that characterised the approach of the AKP compared with its two predecessors, the RP and the FP. By 1995, the RP had emerged as a major political force following electoral victories in the main metropolitan areas of Istanbul and Ankara during the municipal elections of 1994. The party's rise continued in the general elections of December 1995. It emerged as the leading party capturing 21.4 per cent of the vote and was able to form a coalition government as the major coalition partner (Öniş; 1997; Yavuz, 2003; Toprak, 2005). While the RP was moderate by the standards of most Islamist political movements and was a coalition of a diverse set of interest and tendencies, it had some authoritarian leanings, raising doubts in the public mind about how far it would respect a pluralistic political order. It appeared that the party conceived of democracy in rather instrumental terms in their quest to change the Turkish state and Turkish society in a more Islamist direction. In the economic sphere, their underlying model was one of hyper-populism based on heavy state interventionism, in line with their popular conception of the 'just order' (adil düzen). In the foreign policy sphere, their approach involved a strong anti-European dimension in addition to being strongly opposed to the state of Israel. The main thrust of the foreign policy appeared to be the development of strong relations with other Muslim countries, with a clear focus on the Arab Middle East and North Africa.

What is interesting is that this kind of vision encountered serious setbacks and reversals during the course of the 1990s onwards. Certainly, developments in domestic politics played a key role here. RP's authoritarian leanings encountered resistance from both the secular establishment and the society at large. The 'postmodern' military intervention of 28 February 1997 was not a typical military coup and did not involve the replacement of a civilian government by a military government. Nevertheless, the military - through indirect pressure and the warning of a possible coup in the future - effectively facilitated the collapse of the RP-led coalition government in June, and this culminated in the legal closure of the party by 1998. In spite of their authoritarian nature, these events signalled what was broadly permissible within a secular political environment, reflecting the preferences of large segments of the Turkish state and society and their reactions against what appeared to be rising Islamic fundamentalist tendencies.

The Islamists undoubtedly experienced a significant learning process during this episode. The RP's successor, the Virtue Party (the FP), was a political party with a much more moderate political face. Increasingly, 
Table 7.1 Islamists' changing political agenda in Turkey: stylised comparison of Welfare Party (RP) (1995), Virtue Party (FP) (1999) and Freedom and Justice Party (AKP)

\begin{tabular}{lll}
\hline$R P$ & $F P$ & $A K P$
\end{tabular}

Economic role of the State Extremely significant. Strong redistributive role for the state. An active role for the state in subsidising industrial development.

Privatisation de-emphasised.

\section{Democratisation}

No reference to individual or human rights. Major emphasis on social rights and freedom to practise religion.

\section{Nationalism}

Very strong nationalistic flavour. Conceives Turkey as the leader of the Muslim world.

Religion and moral values Very strong. Outlines specific recommendations with special reference to Islamic values and practices. A major distinguishing characteristic of the party programme.
Emphasis on nationalism less pronounced.

Moral values and principles emphasised. However, no explicit reference to Islam or Islamic values. Emphasis on religious freedoms as part of a broader agenda of individual rights and democratisation.

\section{Centralisation versus local government}

Active role for the central government. Minor reference to local government.

\section{Foreign policy orientation} Strong anti-Western and anti-EU bias. Strong opposition to Israel. Favours close relations with the Muslim world.
Strong emphasis on decentralisation and delegation of authority to local government.

Favours an active but balanced approach to foreign policy. Anti-Western and anti-EU attitudes rejected. No explicit reference to Muslim countries.

Defensive and subdued tone.
Strong emphasis on liberal economy and foreign direct investment. Favours privatisation and properly regulated market economy. Some reference to social justice. Provision of social services within the budgetary limits of the IMF programme.

Major emphasis on democratic consolidation through continuing reforms in the realm of civil and human rights. Emphasis on the involvement of civil society. Only occasional references to religious freedoms.

Highly cosmopolitan in outlook; nationalistic element somewhat subdued.

Takes the secular order as its basic reference point. Moral values and principles are considered as broad social norms of Turkish society rather than specific emphasis on Islamic values. Religious freedom as part of a broader programme of democratisation.

Strong emphasis on decentralisation and the policy-making capacities of local governments.

Strong Western orientation with full commitment to EU membership. Open to compromise solutions on key foreign policy issues such as Cyprus. Follows a balanced approach towards Middle East.

\section{Style of politics}

Aggressive, assertive and confident tone. Frequent use of populist rhetoric.
Emphasis on dialogue and consensus-building. Tends to characterise itself as 'Conservative Democrats' and defines itself increasingly as a party of the 'centre'.

Source: Author's compilation. 


\section{Ziya Öniş}

the emphasis shifted to the extension of religious freedoms within the boundaries of the existing secular order. The FP was much more marketfriendly in its approach to economic policy and much more supportive of developing close relations with the European Union. Even the FP, however, could not escape from legal closure, which, in part, reflected the authoritarian bias of the Turkish state (see Table 7.2). The outcome of this decision was to generate a massive internal debate within the party between the 'modernisers' and the 'traditionalists', leading to fragmentation. The result was the emergence of two separate political parties, with the modernisers constituting the backbone of the newly founded the AKP. Looking back, it is noteworthy that the degree of intra-party debate was much stronger in the late 1990s in the FP than in the older, more leaderdominated parties of the centre-right and the centre-left.

State policies and disciplines were not alone in triggering a process of fragmentation and transformation. Certainly, a discursive change among Islamist intellectuals and civil society organisations was also in evidence, which helped the 'modernisers'. Important civil society organisations such as major business association, the Independent Industrialists and Businessmen's Association (MÜSÏAD), which had provided the backbone of the RP and represented a moderating force within the movement, underwent a significant change in outlook by the end of the decade. MÜSÏAD began to place much more emphasis on the theme of democratisation, the extension of civil and human rights and integration with Europe. Similarly, the discourse of Islamist intellectuals in Turkey has been undergoing a parallel transformation leading to their increasing embrace of the liberal democratic norms and values. ${ }^{4}$

Naturally this brings us to the increasingly important role the EU plays in shaping the preferences of leading political actors, including the Islamists, long before the crucial Helsinki decision of December 1999 at which the European Union's Council of Ministers granted Turkey candidate country status. Even the RP when it came to office agreed to operate within the boundaries of the newly signed Customs Union agreement with the EU. Certainly, the RP's successors were much more positive in their attitudes towards the EU, increasingly seeing the EU as a necessary safeguard against the long-established state elites and as a vehicle to consolidate their position in society. ${ }^{5}$ The fact that the EU did not particularly object to the closure of the RP, but was more critical when it came to the closure of the FP, provided important signals both to the state elites and to Islamist politicians themselves. Notable decisions taken in Europe such as the decision by the European Court of Human Rights to endorse the closure of the RP and, more recently, the banning in France by the French government of wearing headscarves in public places, have had further conditioning and boundary-setting effects on the range of permissible politics in the Turkish context. The growing trend within EU countries 
Table 7.2 Major turning points in defining the space for, and boundaries of, political action for Islamist political parties in Turkey

Internal
27 March 1994
Significant increase in the votes of
$\mathrm{RP}$ in local elections (19 per cent
of the vote) recording victories in
major metropolitan centres such as
Ankara and Istanbul.

\section{December 1995}

Victory of RP in general elections. RP emerged as the leading party, but was unable to form a majority government.

\section{June 1995}

RP-DYP (True Path Party) coalition government established under the Prime Minister Necmettin Erbakan.

\section{February 1997}

'Postmodern coup' and the forced resignation of the government.

12 February 1998

Closure of RP.

\section{May 1999}

Merve Kavakçı's attempt to attend the opening ceremony of the Grand National Assembly of Turkey wearing a headscarf, thereby violating a basic constitutional principle.

May 2000

FP Congress and emergence of division within party over the candidacy of Abdullah Gül for party leadership.

\section{June 2001}

Closure of FP.

\section{August 2001}

Foundation of the new party, AKP.

\section{November 2002}

Victory of AKP in the general elections by acquiring 34.8 per cent of the vote, which enabled it to form a single party government with a comfortable majority.

\section{External}

\section{October 1996}

Reactions of US and Europe to the foreign policy of the coalition government of the RP and the DYP, which appeared to take a strong antiWestern stance.

\section{June 2001}

Increased concerns by the European media over the closure of the more moderate FP because of the implications for democratisation in Turkey and the future of Turkey-EU relations.

\section{June 2001}

Approval of RP's Closure by European Court of Human Rights.

\section{February 2004}

French government prohibits the headscarf, conceived of as a symbol of Political Islam, in French schools.

\section{December 2004}

Closure of Belgian Radical Party, Vlaams Blook.

30 June 2004

Application of AKP to the EPP for membership.

\section{January 2005}

EPP gives observer status to AKP.

\section{November 2005}

The Decision of European Court of Human Rights endorsing the official position of the Turkish State involving the ban on the wearing of headscarf in public places, resulting in the rejection of the application by Leyla Şahin, a student from Istanbul University who wanted to attend the university with a headscarf. 
to restrict the use of religious symbols in public spaces and tougher action taken against radical right-wing parties will inevitably influence the domain of action of Islamist politics in Turkey.

\section{The principal bases of the AKP's electoral success}

The extraordinary electoral success of the AKP in the November 2002 general elections (winning 34.28 per cent of the votes and 363 seats in the Parliament) following a decade of political instability featuring successive coalition governments, represented a major turning point in Turkey's political and economic trajectory. The explanation takes several forms. First, the party has been extremely successful in constructing a crossclass electoral alliance incorporating into its orbit both winners and losers from the neo-liberal globalisation process. Business support, notably from small and medium-sized business units falling under the umbrella of a major nationwide business association, constitutes a crucial element of the AKP's electoral support. Second, there is the strong track record of the AKP's predecessors at the municipal government level. Third, the failures of the established conventional parties of centre-right and centre-left in achieving sustained and equitable economic growth, avoiding damaging financial crises and tackling pervasive corruption also paved the way for the AKP's unprecedented electoral success. In spite of its Islamist roots and a natural association in terms of its leadership and core bases of political support with the Welfare and the Virtue Parties, the AKP has nevertheless managed to present itself as a new face with a claim to the very centre of Turkish politics. Hence it was able to form a broad electoral coalition.

Explaining the rise of the AKP is not difficult, but will the party be able to consolidate its power and establish itself as a major force in Turkish politics for several years to come? Clearly, an adequate answer to this question requires a systematic and critical analysis of the AKP government's performance, notably in the economic realm. Up to now, our assessment in this context is quite favourable, though with certain reservations; and no major setbacks are expected until the next general elections, at least, which are likely to be held in November 2007.

There is no doubt that the financial and economic crisis of 2001, which has been the deepest crisis that Turkey has experienced in its recent history and which produced negative repercussions on all segments of Turkish society - rich and poor, educated and non-educated, urban and rural - had a devastating impact on the electoral fortunes of established political parties in Turkey. ${ }^{6}$ An indication of the magnitude of the crisis is provided by the fact the growth rate was -7.4 per cent, while per capita GNP declined from US\$3,095 to US\$2,261 during the course of 2001 and unemployment increased by one million. ${ }^{7}$ Clearly, the three parties 
that saw a collapse in their electoral support were the parties that made up the coalition government that had come into office after the April 1999 elections and, ironically, can be credited with unintentionally paving the way for some of Turkey's recent economic and political reforms. The leading party in the coalition government, the Democratic Left Party (the DSP) led by Bülent Ecevit experienced a total collapse. Similarly, the Nationalist Action Party (the MHP) and the Motherland Party (the ANAP) also experienced dramatic declines in their electoral base. Indeed, by the time of the next general election in November 2002 none of the three members of the coalition government was able to reach the 10-per-cent threshold of the vote, and after 1999 they were effectively excluded from participation in parliamentary politics. The True Path party (DYP), which was yet another party that was not in government in the years 1999 to 2002 but nevertheless had been a significant political force in the 1990s, also found itself relegated to the sidelines. Centre-left parties were penalised for failing to protect the interests of the poor and the underprivileged, and centre-right parties suffered, in addition, from their association with widespread corruption.

The AKP, as a new force, capitalised on the situation and presented itself to the electorate as a progressive force that could bring benefits from the positive aspects of economic globalisation, based on active participation and competition in the global market. At the same time, the AKP's approach indicated a genuine concern with issues in social justice to do with the distribution of material benefits and extension of individual rights and freedoms. Compared to its rivals, in particular the CHP, the AKP appeared to be forward-looking and reformist, rather like a Europeanstyle social democratic party of the 'third way'. With its emphasis on the benefits of the market, the need to reform the state in the direction of a post-developmental regulatory model, commitments to multiculturalism and social justice and the extension of religious freedoms, and disposition in favour of EU membership, the AKP made the CHP look inward-oriented and conservative, judged by European standards. ${ }^{8}$ The CHP did have the advantage of not being in government or, even in parliament in 1999-2002, and so it, too, could try to present itself as a new face. But it could not get rid of a heavily nationalistic and statist orientation, and its attachment to a rigid version of secularism alienated it from significant segments of Turkish society that favoured an extension of religious rights and freedoms within the boundaries of a secular state. All things considered, the AKP benefited from the absence of a powerful rival. The continuing absence of a genuine alternative from either the right or the left with the capacity to adapt to changing circumstances and the new parameters within which Turkish politics operates may help to accentuate the dominance of the AKP even further over the next few years. ${ }^{9}$ 


\section{Ziya Öniş}

\section{The Turkish counterpart to Christian democracy?}

The emergence of the AKP as the dominant force in Turkish politics in the elections of November 2002 also represented a turning point in Turkey-EU relations. ${ }^{10}$ Here was a new party with strong Islamist roots but nevertheless far more moderate and centrist in terms of outlook than its predecessors. Even more interesting, the party presented itself as an active and vocal supporter of EU membership. Indeed, once in office it pursued the EU-related reform agenda with a far greater degree of consistency and commitment than had the previous coalition government. The AKP has now established itself as the dominant component of the proEU coalition. This has contributed towards the development of a sizeable pro-Turkey coalition within the European Union itself.

The AKP is a broad-based political movement with a pragmatic ideology. The fact that leading figures in the party as well as its core electoral support have previously been associated with the Islamist parties at first generated considerable scepticism among secular elements of the Turkish state and society, as well as the international community. But it soon became clear that the party was more moderate than its predecessors (see Table 7.1). Certainly it has a strong conservative streak, with a major emphasis on religion, morals and the need to preserve traditional values. This is manifest in relation to issues concerning women's rights and gender equality. Indeed, the party's own self-description is that of 'conservative democrats' identifying a close affinity in the process with their Christian democratic counterparts in Western Europe. ${ }^{11}$ And the party's electoral base is a crossclass coalition that includes small and medium-sized enterprises who have benefited from the neo-liberal reforms that globalisation has brought. The fact that business is an important component of the party's electoral base is another attribute that naturally leads many commentators to interpret the party as a party of the centre-right. It is also striking that the AKP more than any other political party in Turkey has tried to forge close, organic institutional links with its Christian Democratic counterparts in Europe. In fact it has been granted observer status within the EPP (in contrast, the CHP is a long-time member of the Socialist International, but the party's nationalistic attitude and inward-looking orientation mean its links with the larger organisation are weak in practice). Institutionalised links of this nature are a good example of how party politics is becoming more globalised, and is likely to mean that a party such as the AKP will be induced to observe international norms in order to become and remain a member of the club.

At the same time, however, there are parallels between the AKP and the 'third way' style of social democracy that has been popular in European discourse, given the party's apparent commitment to the principles and values of cosmopolitanism, multiculturalism, social justice and a properly regulated market economy. A benign view is that the AKP wants to extend 
the boundaries of religious freedom and encourage religious diversity rather than challenge the idea of secularism as a constitutional principle. Moreover, in its policy rhetoric it seems to pay more attention to social justice and the plight of the poorest than do Christian Democratic counterparts in Western Europe, although its ability to accomplish anything concrete in these matters is severely constrained by the financial discipline that it has had to impose on public spending, in connection with the IMF's programme of support. Social democratic politicians in Europe, the principal supporters of Turkey's bid for EU membership, have tended to be much more sympathetic to the AKP than to the CHP, its putative social democratic counterpart in Turkey.

The AKP has effectively captured the ground that was previously occupied by both the centre-right and the centre-left parties in Turkish politics. It has the country's financial and economic crisis to thank for that. Representing a unique synthesis of reformism and conservatism, it has been able to consolidate its power and popularity even further, both in domestic and international circles, by displaying a mixture of pragmatism - in terms of implementing fiscal discipline and neo-liberal economic reforms - and radicalism, by implementing EU-related political reforms. The result has been a mixture of economic recovery and a further opening of the political space for democratic participation in Turkey. Evidence of economic recovery is provided by the fact that the average growth rate per annum over the course of the 2002-05 period emerged as 6.9 per cent, while inflation rates fell to single-digit levels for the first time for three decades. These trends were set in motion before the AKP came to power, but by accelerating the momentum the party has been able to reap much of the credit. More striking still, perhaps, has been a significant shift of foreign policy behaviour away from a hard-line nationalistic stance and towards a more balanced and pragmatic approach. This is clearly evident in regard to the Cyprus problem, which has long constituted an obstacle to Turkey's aspirations to EU membership. The AKP government was effectively the first government in Turkey to welcome a compromise solution that would bring the dispute to a peaceful conclusion. A trend towards more 'balanced' foreign policy behaviour was also evident in the government's attitude towards the US invasion of Iraq and in relations with the United States, as well as relations with Israel and the Arab world. Relations with all neighbouring countries have improved.

Putting the AKP experiment in broader context, what is striking is that Turkey's Islamic identity had been identified by some as a source of difference, providing an argument for exclusion from the European Union. The typical line of argument here - drawing on Samuel Huntington's polarisation of East versus West - was a concern that Turkey's true Islamic identity would be lost sight of as the process of getting closer to accession to the EU unfolded. But on the contrary, the AKP as a party bearing 


\section{Ziya Öniş}

a moderate Islamist orientation has been the central political actor in bringing secular Turkey closer to the centre of the European project. Indeed, a seeming paradox is that moderate Islamists in Turkey have seen the importance of EU membership for Turkey as a means of consolidating and solidifying their own position against possible threats to them from the hyper-secularism of the established state elites and important sections of Turkish society. The boundaries of religious freedoms have been expanded in the process. Hence, in a rather unexpected fashion the prospect of European integration has become a mechanism for preserving Turkey's Islamic identity and making it more compatible with a secular, democratic and pluralistic political order.

With Turkey having gone through a process of radical reforms and with the experience of the early years of the AKP government to draw on, we are now in a stronger position to argue that the Turkish synthesis of secularism and democracy in a predominantly Muslim setting can offer a credible alternative to the rest of the Muslim world. An obvious qualification is that the 'secularism versus Islam' divide and the debate over the boundaries of secularism are still far from being resolved. And significant elements both within the state and the society at large continue to view the AKP's moderate image with considerable suspicion. Indeed, the government has by and large sidelined contentious issues such as the wearing of headscarves by women in public spaces, so as to prevent an increase in tension and avoid serious conflict. ${ }^{12}$ Certainly, the AKP's own commitment to 'multiculturalism' is open to question given that the party has so far not been very receptive to the idea of extending religious rights to Christian minorities as well as Muslim minorities such as the Alevis. Perhaps it is fair to say that, after initial reservations, the international community has been more receptive to the AKP government even while serious divisions remain within Turkish society.

What is also critical in this context is that while the European Union places a very high premium on secularism it does not offer a single blueprint for concrete practice. Indeed, within the EU there exists a variety of national models concerning the translation of the principle of secularism to actual implementation. Hence, the EU has helped to push Islamists in Turkey in a more moderate direction, by restricting the space within which they can operate. However, this does not mean that EU membership by itself can resolve completely the secularism-Islam divide in Turkey. The issue will continue to arouse controversy, in Turkey and in Europe. In Turkey there is scope to further extend religious freedoms, but progress will depend on the ability to develop and agree upon compromise solutions, without looking for some standard pattern from the EU. The fact that the AKP government has so far been able to postpone dealing with a controversial issue such as the headscarf issue does not mean that such issues have gone away. 


\section{Can the AKP maintain its electoral dominance?}

By the end of 2004, the position of the AKP as the dominant force in Turkish politics appeared to be secure for the foreseeable future. The decision of the European Council in December to start the process of accession negotiations with Turkey by October 2005 was clearly a favourable development that helped to bolster the AKP. A major setback on the EU front in December 2004 could well have triggered a vicious circle of negative reactions in the financial markets, leading to a serious economic downturn that would quite easily have undermined the comfortable standing currently enjoyed by the AKP. It would be premature to predict that the position still enjoyed by the AKP represents a kind of medium-term or long-term equilibrium in Turkish politics. A number of developments both on the domestic and external fronts could result in a political reversal. The performance of the economy remains a critical factor. If it can continue to grow at rates of 6 or 7 per cent per annum, then the distributional conflicts that have been all too common in the past can be contained. But this will require large inflows of foreign direct investment and significant improvements in domestic savings, investment and productivity. The data indicate a striking increase in foreign direct investment (FDI) in the country in the post-crisis era. FDI inflows amounted to US\$3.7 billion in 2005, up from just US\$1.1 billion in 2002. ${ }^{13}$ The investment climate has improved in recent years as a result of the government's strong commitment to fiscal discipline and the broadly favourable development in relation to EU accession. Nevertheless international competition for inwards investment will remain intense.

A low growth scenario, then, could have serious political consequences. Furthermore the accession negotiations with the EU are likely to entail making costly adjustments including restructuring the agricultural sector, which accounts for 14 per cent of gross domestic product (GDP) and, even more striking, still some 35 per cent of the workforce. Coming into line with EU standards and norms will mean implementing demanding regulations. Hitherto, Turkish public opinion has been heavily in favour of EU accession primarily because of the material benefits that are anticipated from full membership. But if the economy falters and the adjustment process demanded by accession negotiations imposes heavy costs, the enthusiasm shown by significant sections of Turkish society within and outside the business community could decline. A revitalisation of the nationalistic and Euro-sceptic bloc in Turkey cannot be ruled out in these circumstances. Indeed, the political contest in Turkey during the coming years is likely to take place among the different segments of the centre-right involving the 'Muslim Democrats' and the nationalists, in an environment where European-style social democracy still does not exist. Signs that the electoral contest in Turkey might already be moving in this direction began to appear in the municipal elections of March 2004, which 


\section{Ziya Öniş}

saw a marked improvement in the electoral fortunes of two nationalistically and Euro-sceptically inclined parties, the MHP and the DYP. The fact is that the economic recovery that Turkey has experienced since 2001 has yet to translate into improvements in rural poverty and unemployment, especially youth unemployment. The magnitude of the problem becomes evident from a brief inspection of the unemployment rate for the educated youth - currently standing at 28 per cent, whereas the overall unemployment rate is 10 per cent. Similarly, if the economy continues on a high-growth path, then small business is more likely to share in the benefits, and distributional conflicts with large business units can be avoided, but in a less dynamic economic environment small and mediumsized business, too, may start looking around for alternative avenues of political representation to the AKP.

In a deteriorating economic climate, then, the broad coalition that the AKP represents could begin to crumble, especially if it is no longer able to avoid facing up to the kind of thorny political issue of which the lifting of the existing ban on the entry of girls with headscarves into universities is a good example. That sort of initiative might bolster its core support but would cause serious opposition from the secular establishment. The fault lines that separate Islamists and secularists in Turkish society have certainly not disappeared. Indeed, whenever the AKP government has tried to push sensitive identity-based issues on the policy agenda, the outcome has been resistance and conflict with the secular political establishment. Hence for the most part the approach in government has been cautious and pragmatic. But in the course of time that could come to alienate its core supporters. For those supporters there are alternatives: at the present time there is the 'Happiness Party' (Saadet), which represents the linear descendent of the Erbakan-style 'National Outlook Movement' (Milli Görüss). This party captured just 2.5 per cent of the vote in the general election of November 2002, but could yet take support from the AKP. Another possibility is that nationalist parties erode the AKP's present dominance; they did well in the general election of April 1999, when the ultra-nationalist MHP gained ground at the expense of the Virtue Party. The MHP, with its special brand of nationalism and Euro-scepticism on the one side and religious conservatism on the other, could well emerge as a major rival to the AKP, if the different elements of the AKP's underlying coalition of support begin to feel dissatisfied - for a variety of rather different reasons - and change their party preference. The resurgence of violence orchestrated by the Kurdish Workers' Party (PKK) and increasing demands by the Kurds for greater political recognition may be other factors that could contribute to a nationalistic backlash, presenting further challenges to the AKP in the coming years.

Also, we should not discard the possibility that external developments might play a destabilising role with potentially negative consequences for 
the AKP specifically. The path towards EU membership will continue to be an uphill struggle. Considerable divisions over membership by Turkey remain within the EU, notwithstanding the accelerating pace and depth of reforms taking place in the country, and these divisions by and large did not exist in the accession process of the new members from Central and Eastern Europe. By sending a relatively ambiguous and lukewarm signal to Turkey, the EU actually renders the job of a government committed to the implementation of EU-related reforms more difficult. Added to this there is still the dispute over Cyprus, which could prove a stumbling block in the accession process. Instability in Northern Iraq and deteriorating relations with the United States also pose challenges. All these considerations suggest that the extraordinary success of the 'Muslim democrats' in the past few years does not necessarily represent a stable equilibrium, given the fragile domestic and external context of Turkish politics.

\section{The broader significance of the Turkish experience}

The central message of this chapter is that an Islamist political movement can transform into a party promoting Western integration and liberal democracy. At the same time, there is nothing inevitable about the emergence and consolidation of liberal democracy in a predominantly Muslim setting. The historical context matters, and the outcome depends on the intersection of a combination of forces both domestic and external. The case of Turkey illustrates how liberal democracy can take root and flourish as an example of a secular state in a predominantly Muslim setting, with the qualification that liberal democracy is still in the process of being consolidated in Turkey. In retrospect, several factors have contributed to the emergence of this benign development so far, in a specific historical setting.

The constitutional order of the modern republic with its strong commitment and arguably authoritarian interpretation of secularism was extremely important in the first instance, by excluding the radical alternative of an Islamic state right from the very beginning. The principle of a secular political order is a pre-condition for a liberal democratic order, although the boundaries and the implementation of secularism in everyday life constitute an area for political contestation. The Kemalist nation-building project in Turkey with its own brand of secularist ideology made a positive contribution by helping to define the boundaries within which the Islamists could operate, although it also played a repressive role in terms of restricting the boundaries of political participation.

Representative democracy, in spite of its shortcomings, has been the norm since 1945. There is no doubt that the Islamists in Turkey have experienced a learning process. The democratic order has helped to shape 


\section{Ziya Öniş}

the demands of the Islamists in a more moderate direction, realising that compromise solutions were vital for the effectiveness and very survival of Islamists as a political force within the boundaries of the secular process. Indeed, the learning process accelerated especially in the aftermath of the 'February 28 Process' - the 'postmodern coup' that effectively brought about the collapse of the coalition government led by the Welfare Party in June 1997 and the subsequent closure of the Welfare Party. This rapid learning process was arguably at the heart of not only the AKP's electoral success but also its ability to consolidate its position after assuming power in November 2002. Indeed, a kind of virtuous cycle appears to have emerged in Turkey in recent years, with the democratisation of the political regime leading to the democratisation of the Islamists themselves, and then the Islamists, in turn, ironically taking up a key role in the further democratisation and Europeanisation of the Turkish political system.

Turning to the economic realm, the emergence of a significant middle class or 'counter-elite' within the Islamist movement, including intellectuals and businessmen as well as highly educated professionals who have benefited from the processes of globalisation and neo-liberal economic restructuring, have clearly helped to tilt the balance in a moderate direction. This new bourgeoisie has set its sights on enlarging the boundaries of freedom and political participation and improving their social status and access to state resources. An open clash with the secular establishment is clearly not in their interests. Turkey's empirical realities lend strong support to the observation that the emergence of a strong middle class is a crucial pre-condition for the emergence of liberal democracy.

Finally, the European Union has played and is likely to continue to play a critical role in making Islam and liberal democracy compatible in Turkish setting. The role of the EU has been particularly striking in re-shaping the outlook of the Islamists in Turkey, who increasingly came to see the EU as a necessary safeguard for protecting their own identity against the secular state establishment. Consequently, the Islamists or, more recently, the Muslim Democrats have become the most vocal element of the pro-reform or the pro-EU coalition in Turkey. The prospect of EU membership helped to provide a common project for different elements of the Turkish society and as a result helped to soften the fundamental secular-Islamist divide in Turkish society.

Highlighting the importance of contextual changes inevitably suggests that it would be misleading to think of the Turkish example as a 'model' that can easily be transplanted to the Arab Middle East. It is equally wrong to argue that the Turkish experience holds no relevance for the Arab Middle East, given that the elites there, for a variety of historical reasons - the Ottoman legacy of imperial rule, the way that secularism has been put into practice during the modern Republican era and Turkey's 
single-minded orientation towards the West - have tended to distance themselves and have been unenthusiastic about the idea of a 'Turkish model'. Both Turkey and the region as a whole are in flux and undergoing a process of deep-seated transformation, so past perceptions may provide only limited guidance to future developments. ${ }^{14}$

So the relevance of the Turkish experience as an example (it is not an exportable model) will depend both on the nature and speed of the political liberalisation process in the Middle East region and on Turkey's own performance in economic and political reform, and on smooth transition to EU membership. Certainly the more enclosed and authoritarian regimes of the Middle East and Central Asia are likely to visualise the Turkish experience as an existentialist threat and may well seek to distance themselves from this ongoing experiment as much as possible. In contrast, regimes that are in the process of being liberalised are likely to be more receptive to the Turkish experience. Interestingly, therefore, the greater the degree of democratisation in the region, the greater will be the relevance of the Turkish experience, which in turn should help to contribute to the economic development and democratisation of the region even further. Added to this, the fact that the recent 'Europeanisation' of Turkish foreign policy has resulted in a more balanced foreign policy behaviour towards Israel and the Arab states is also likely to increase the receptivity of policy-makers and intellectuals to the ongoing transformation process that Turkey has been experiencing.

\section{Notes}

1 See Çarkoğlu and Toprak, 2000, and on the historical context of Turkey's experience with secularism see Toprak, 2005. A good discussion of the distinction between secularism as a constitutional principle and the specific secularist ideology of the Turkish state is Davison, 2003.

2 For an optimistic and yet qualified assessment of the compatibility of Islam and democracy in Turkey see Heper, 1997.

3 On the nature of civil society activism and the role of intellectuals see Keyman and Içduygu, 2005.

4 See in this context the important study by Daği, 2004.

5 On the need to take account of the role of the EU in transforming Islamist politics in Turkey see Öniş, 2001, Taniyici, 2003 and Toprak, 2005.

6 The economic crises are discussed in Öniş and Rubin, 2003.

7 The key macro indicators are taken from Devlet Planlama Teşkilatı (State Planning Organisation), Temel Ekonomik Göstergeler (Main Economic Indicators), Ankara, various issues.

8 On the role of the AKP see Ayoob, 2004 and Öniş and Keyman, 2003.

9 For more on the party system and the main parties see Heper and Rubin, 2002.

10 On the November 2002 general elections see Öniş and Keyman, 2003.

11 For a comparison of the AKP and Christian Democrats in Europe see Nasr, 2005. 


\section{Ziya Öniş}

12 The only exception has been the introduction, in May 2004, of the Higher Education Bill, which extended opportunities for graduates of religious secondary schools (Imam Hatip Liseleri) to attend university. The government withdrew the proposal following strong opposition.

13 Treasury data. Online. Available www.hazine.gov.tr/stat/yabser/dyyt.xls (accessed January 2006).

14 For evidence of a recent shift in perceptions regarding Turkey in the Arab Middle East, see Jung, 2005. 


\title{
8 Globalising party politics in Africa
}

\author{
The influence of party-based \\ democracy networks
}

\author{
M. A. Mohamed Salih
}

\section{Introduction}

African political party-based democracy is an extension of Africa's colonial and imperial legacy and post-independence incorporation into global policy agendas, party-to-party and parliamentary partnerships and networks. Paradoxically, despite myriad global influences, party-based democracies have retained much of Africa's nascent quasi-polyarchical traits, characterised by ethnic, religious and regional cleavages, political patronage and weak internal party democracy. Specifically, this chapter compares and contrasts the accession of the major political parties in Ghana, Kenya and Malawi to global party-based democratic networks, and their influence on political programmes and policy orientations in an era of neo-liberal globalisation. The chapter also examines which aspects of African party-based democracy have, and which have not, been globalised. The view that Africa's parties oscillate between globalisation and localisation contradicts the idea that African political parties, and indeed African political institutions more generally, are under threat of being 'universalised' as a consequence of the ascendancy of globalised partybased democracy.

\section{The emergence of political parties in Africa}

African political parties emerged in the non-democratic setting of colonial rule. A reformed colonial state after 1945 sought to include Africans in the administration of their affairs. It created an educated political elite experienced in operating Western-style political institutions. And Africans, under strict political surveillance, were allowed to establish political parties in order to oversee the machinery of government when their countries attained independence. In the urge to leave behind political institutions similar to those of the West, the departing colonial governments exported to Africa their particular versions of parliamentary government, which involved competing parties and recognised the idea of opposition. 
In practice, due to the speed with which developments unfolded, numerous ethnically based parties appeared. They were encouraged by colonial rule because ethnic groups offered organised groups that were instantly available for political party formation (Mohamed Salih, 2003: 2). However, at that time the significance of ethnic divisions was secondary to the synthetic nationalism whereby all the parties remained focused on attaining the cherished goal of independence.

Political parties were established, assumed the structures and functions of Western-style political parties and, in most places, managed to see their countries through independence to self-rule. In some countries, it took the emerging African elites less than a decade to go from establishing political parties to contesting elections and subsequently governing their countries. However, in less than a decade of attaining independence, and with the waning of the nationalism that was a short-lived consequence of decolonisation, sub-nationalist and ethnic politics began to rise (Sithole, 1959). Moreover, fuelled by the cold war and internal divisions, party-based democracy was the first victim of the elite's political excesses. In some countries, the severe ethnic cleavages that fuelled sub-nationalism led to civil wars, liberation movements and political instability. ${ }^{1}$ These developments were the greatest obstacle to party-based democracy; authoritarian regimes stepped in and banned political parties, curbed trade union activities and civil liberties, and in some places introduced constitutionally sanctioned one-party states.

The colonialists viewed political parties as hostile, despite the fact that some examples had joined alliances with colonial rule, participating in constituent assemblies that were considered an extension of colonial rule (Mohamed Salih, 2003: 3). To that extent, the constituent assemblies had restricted powers, often overruled by the Governor General, and were allowed to debate only those issues that posed no security threat to the colonial state. For instance, in most British colonies Africans comprised only a small fraction of the membership of the constituent assemblies, which were also members of the Empire Parliamentary Association (InterParliamentary Union, 1976).

Certainly, African party-based democracy was born of the colonial state coloured with the distinct hybrid of African political culture and Western political thought. This meant that, on the one hand, the emergent political parties championed independence and were considered hostile to colonial rule and, on the other, adopted the dominant Western partybased democracy and its ideological perspective of the time. There are two significant implications of these origins of African party-based democracy. First, the colonial era had sown the seeds of globalised party-based democracy even before the emergence of the current wave of globalisation. It is therefore relevant to the contention that developing countries' globalised political institutions have their antecedence in the colonial and imperial expansions. Second, the consequences of neo-liberal globalisation 
for national political institutions and specifically political parties now do not represent a simple rupture in political party development. Instead there are twin processes of continuity and change, informed by the new global context of political development.

Until the early 1990s, most African parties subscribed to one of two dominant global ideological trends: socialism/communism and a vaguely defined 'liberal democratic' form of government. Admittedly, there were only a few African party-based democracies. For much of the period two-thirds of the continent endured authoritarian one-party states, military socialism or military dictatorships. With the end of the cold war, however, party-based democracy acquired prominence at the global level, with multi-partyism becoming synonymous with democracy. In Africa, the resurgence of multi-party democracy during the 1990s was a result of the triumph of the neo-liberal paradigm over various forms of authoritarianism (Horowitz and Plattner, 1993). 'Institutionalism' became the dominant force informing economic and political liberalisation, as international financial institutions such as the World Bank and the IMF preached the primacy of 'institutionalism' and, in the case of economic governance, the market and New Policy Management (NPM). In respect of political liberalisation, the rule of law and good governance (Desai and Redfern, 1995) became the driving force behind the enshrining of the ethos of global democratic governance.

If for many people in Africa economic globalisation has become synonymous with economic liberalisation, free trade and market principles, then political liberalisation has become synonymous with democratisation, often being directly linked with the prevalence of multi-party democracy, hence party-based democracy. Globalised party-based democracy in Africa cannot, therefore, be isolated from global developments and the influences that have shaped its structure and policy orientations. In particular, political liberalisation has invoked a series of political reform programmes, which in most countries has included constitutional reforms to allow the formation of political parties and civic associations. This has opened up the political space for electoral competition and has reformed statutory, penal and administrative structures that had once impeded political activities outside the confines of the ruling political party. Examples include lifting the ban on forming parties outside the ruling party. These political, legal and administrative reforms extended civil liberties previously curbed under authoritarian one-party regimes, and allowed the emergence of autonomous civil society and non-governmental organisations.

The following explores how political parties in Ghana, Kenya and Malawi have reacted to neo-liberal globalisation - in particular, how they translated their party manifestos into policy orientations informed by or subservient to the neo-liberal global paradigm. This means examining concrete examples of party principles, programmes and practice, rather speculating more abstractly on how globalisation might affect them in the 
future. It will underscore variations in political party responses in lieu of the economic and political factors that have informed their response to global policy agendas, including democracy. Finally, it will help us determine what aspects of African party-based democracy have not been globalised.

\section{Which aspects of African party-based democracies have been globalised?}

The synoptic working definition of 'globalised party' informing this chapter refers to an emergent globally informed quasi-polyarchy where political parties subscribe to broadly defined party-based democratic principles. It refers to political party policies and programmes that are greatly influenced by global, economic and social policy agendas, thereby contributing to closer integration into neo-liberal economic policies, under the influence of global economic governance institutions such as the World Bank and the IMF. Finally, it means an increasing connectivity and integration into global party-to-party and parliamentary partnerships and networks that advance and promote party-based democracy worldwide.

\section{An emergent globally informed quasi-polyarchy}

'Polyarchy'2 refers to regimes that have been substantially popularised and liberalised, are highly inclusive and are open extensively to public contestation. A near-polyarchy can be relatively inclusive but with greater restrictions on public contestation than a full polyarchy, or it might provide opportunities for public contestation comparable to those of a full polyarchy but is somewhat less inclusive (Dahl, 1971: 5-8). In this sense, many of the world's democracies are, in fact, quasi-polyarchical: they fall short of the ideals of democracy. The reference to quasi-polyarchy in the African context is significant not only because it recognises that there are various degrees of adherence to the democratic ideals accepted as characteristics of global party-based democracy but also because it highlights two main possibilities: first, that polyarchy is a welcome development in countries where it signifies a move away from hegemonic regimes; second, that in countries without recent experience of competitive politics, the transformation of hegemonic regimes into polyarchy is likely to remain a slow process, measured in generations (Dahl, 1971: 47). The relevance of this to Africa (and developing countries more generally) is that their democracies will exhibit certain characteristics unique to their political culture; and attempts to reproduce and export blueprints of Western democracies are likely to be unrealistic, and hardly practicable.

Without exception political parties in Ghana, Kenya and Malawi have subscribed to the overall ethos of polyarchy, both in terms of policy 
orientations and, to a large extent, in practice. The characteristics that inform their political party programmes, policies and manifestos are:

[the] freedom to form and join organisations; freedom of expression; right to vote; eligibility for public office; right of political leaders to compete for support; right of political leaders to compete for votes; alternative sources of information; free and fair elections; and institutions for making government policies depend on votes and other expressions of preference.

(Dahl, 1971: 5)

However, their democracies lean towards quasi-polyarchy even as the parties have generally understood the requirements demanded by democracy's rules of the game and the various conditionalities imposed by the strictures of global governance. Opposition political parties, noting that governments do not always abide by democratic rules, demand full compliance with the ethos of polyarchy. Unfortunately, once in government even the former opposition parties have behaved in ways more reminiscent of quasi-polyarchical and at times exhibit non-democratic tendencies. While it is very easy for opposition parties to preach reform and ask bold questions, once in power they find themselves constrained by policy environments in which they must respond to ever-increasing demands with only meagre resources that governments have at their disposal.

African political parties acquiesce in quasi-polyarchy not only because of external pressures exerted by global governance, democracy and human rights activists but also because versions of polyarchy offer a safeguard against dictatorship and a return to authoritarian rule. Its ethos opens up the political space for competitive politics, which thus offers the possibility of competing in elections and even governing if they become the majority party in parliament. Little wonder, then, that globalised partybased democracy in Africa is largely quasi-polyarchical, as in many other democracies around the world.

\section{Globally influenced political party programmes}

African political parties, with the exception of a few socialist- or Marxistoriented parties, have embraced the major tenets of 'liberal democracy' as reflected in their party programmes, manifestos, charters and either new or rewritten constitutions. The principles of free contestation and participation in the political process meant that the need for 'liberalising' the political space was:

1 a factor of popular and civil society agitation against decades of dictatorship; 
2 demanded by political parties banned for decades from participating in politics or newly formed political parties that offered themselves as alternatives to the single ruling political party;

3 required by global governance, democracy and human rights activism, bilateral or multilateral donor conditionality and global economic governance under the influence and insistence of the IMF and the World Bank in instilling the ethos of good or better governance and political liberalisation on a global scale.

These developments have shaped the political programmes and policies of the major political parties across Africa. To illustrate how neo-liberal global economic and social policy orientations have influenced governments in the 1990s and the political parties' responses, the examples of Ghana, Kenya and Malawi will be cited.

The party composition of Ghana's parliament since the commencement of the Fourth Republic in 1993 is shown in Table 8.1. The distribution of votes illustrates strong competition between Jerry Rawling's National Democratic Congress (NDC) and the New Patriotic Party (NPP). Ghana is evidently a two-party system. Since the 1993 elections, parliamentary discussion and political elite debate has revolved around how the parties could best respond to the economic policy reforms subscribed to by the global finance institutions. There have been no dissenting voices within the ranks of the two main parties, and no demands for government to pursue alternative policies (Aryeetey, Harrigan and Nissanke, 2000). The NDC has been the champion of policy reform and earned a special place with the global finance institutions for rigorously implementing the 'globally' framed economic reform agenda.

However, with the economic slowdown early in the 1990s, the NPP, which formed the backbone of the opposition, gained popular support, accusing the NDC of corruption and an inability to implement the economic reform agenda diligently. In government the NPP is now pursuing an economic policy traditionally associated with the NDC and will perhaps succeed where the NDC has failed. But because no party offers a radically different policy that could pose a serious challenge to the general direction of Ghana's economic reform, it is issues of human rights and the rule of law that have become the focus for policy differences and political contestation. The NDC stresses the primacy of food, shelter, clothing, education and stability as the cornerstone of its human rights policy owing to its socialist ideological orientation (in fact, it is the only Ghanaian party to belong to the Socialist International). The NPP manifesto, in contrast, emphasises the enjoyment of human rights to their full extent and respect for the rule of law, rather than social justice. The competition between different visions of 'fundamental human rights' and 'social justice' is shared by a much more global debate between liberals and social democrats, but it has particular importance for the NPP because it distances the party 


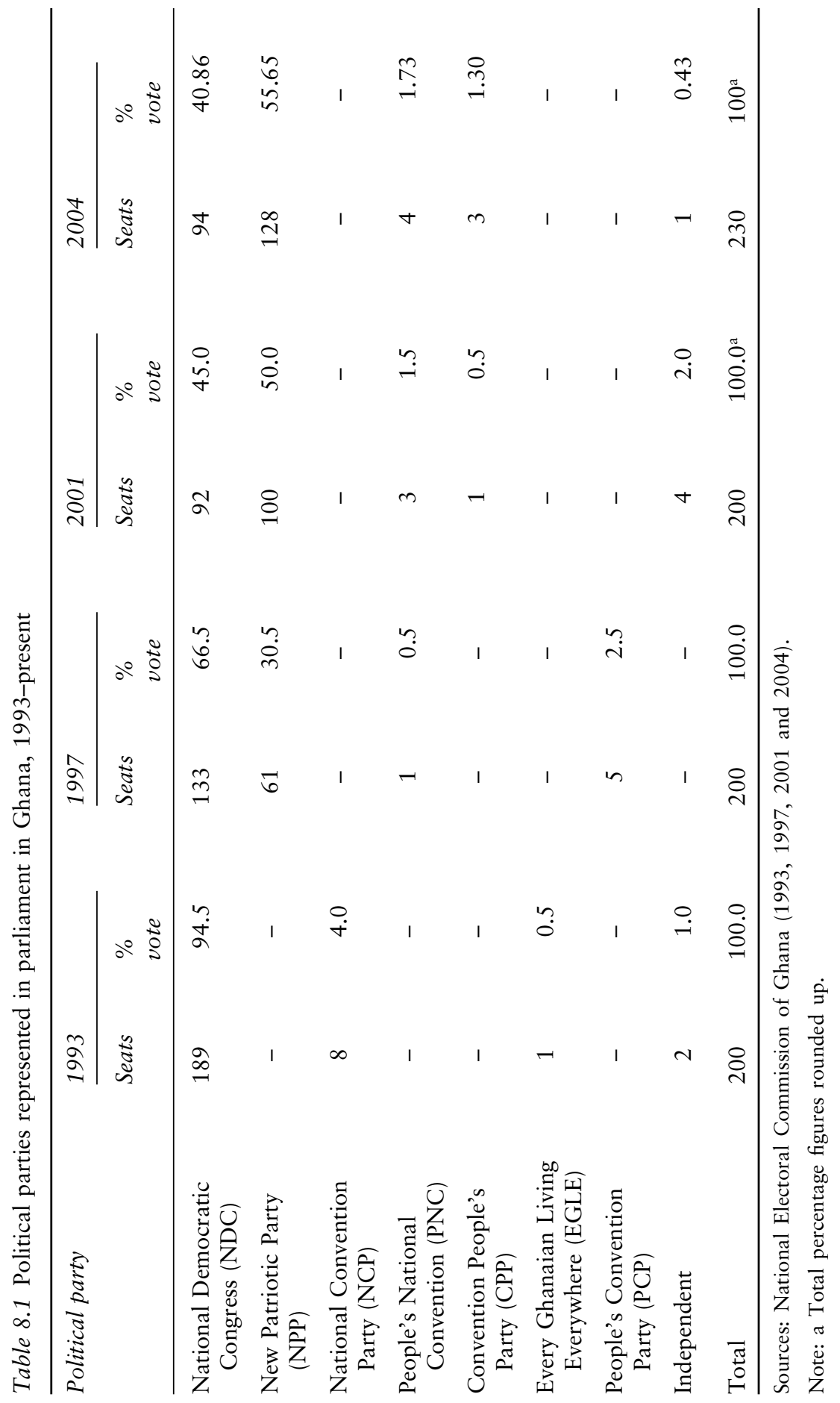


from the abysmal human rights record of the NDC and its association with Rawling's Military Provisional National Defence Council (PNDC) government (1981-92).

Unlike Ghana, which has undergone two unrestricted multi-party elections and where the NPP was able to replace the former incumbent in power (the NDC), Kenya has undergone only one unrestricted multi-party election since independence in December 1963. The electoral victory of the National Rainbow Coalition (NARC) in the 2002 elections, after a bitter struggle by national and global democracy and human rights activists, ended the 40 years of one-party rule by the Kenya African National Union (KANU). Table 8.2 shows the results of the three multi-party elections that have taken place during the post-political reform period. The elections of 1992 and 1997 were fraudulent, unlike the 2002 election, which was relatively free and fair.

However, the NARC's election pledge was centred on pursuing economic policies different from those of KANU. It proposed to revive the economy by a more faithful implementation of IMF and World Bank policies. ${ }^{3}$ Although the NARC comprised a coalition of 14 large and small political parties with different ideological and policy orientations, in government it has continued the economic liberalisation initiated during the closing years of KANU supremacy, including the removal of import licensing, price and foreign exchange controls. In retrospect, it is clear that the IMF and World Bank's suspension of financial support to Kenya in early 2001 - which was in response to the KANU government's failure to implement an Enhanced Structural Adjustment Programme, curb corruption and privatise key inefficient economic sectors - dealt the ruling party a decisive blow. It created a sense of paralysis in the implementation of the Poverty Reduction and Growth Facility Programme and Economic and Public Sector Reform, which the international financial institutions had previously promised to support. In the same year, Kenya experienced a serious economic recession. Kenya's GDP actually shrank by 0.3 per cent, almost reminiscent of the negative growth rates of the mid-1990s.

In common with Kenya and Ghana, Malawi's transition to multi-party democracy came about as a result of popular struggles supported by the proactive solidarity of global democracy networks and activists. President Hastings Kamuzu Banda, the chair of the Malawi Congress Party (MCP), which governed the one-party state for 30 years, accepted the 1993 referendum that rejected the continuation of single-party rule and opted for multi-party democracy. The first multi-party election took place in 1994 and the MCP, the incumbent party, lost (see Table 8.3).

The political programmes and manifestos of Malawi's major political parties and coalitions that have supplied the three governments since 1994 have all been informed by the dominant neo-liberal economic paradigm. They are almost identical to those pronounced by the governing and 


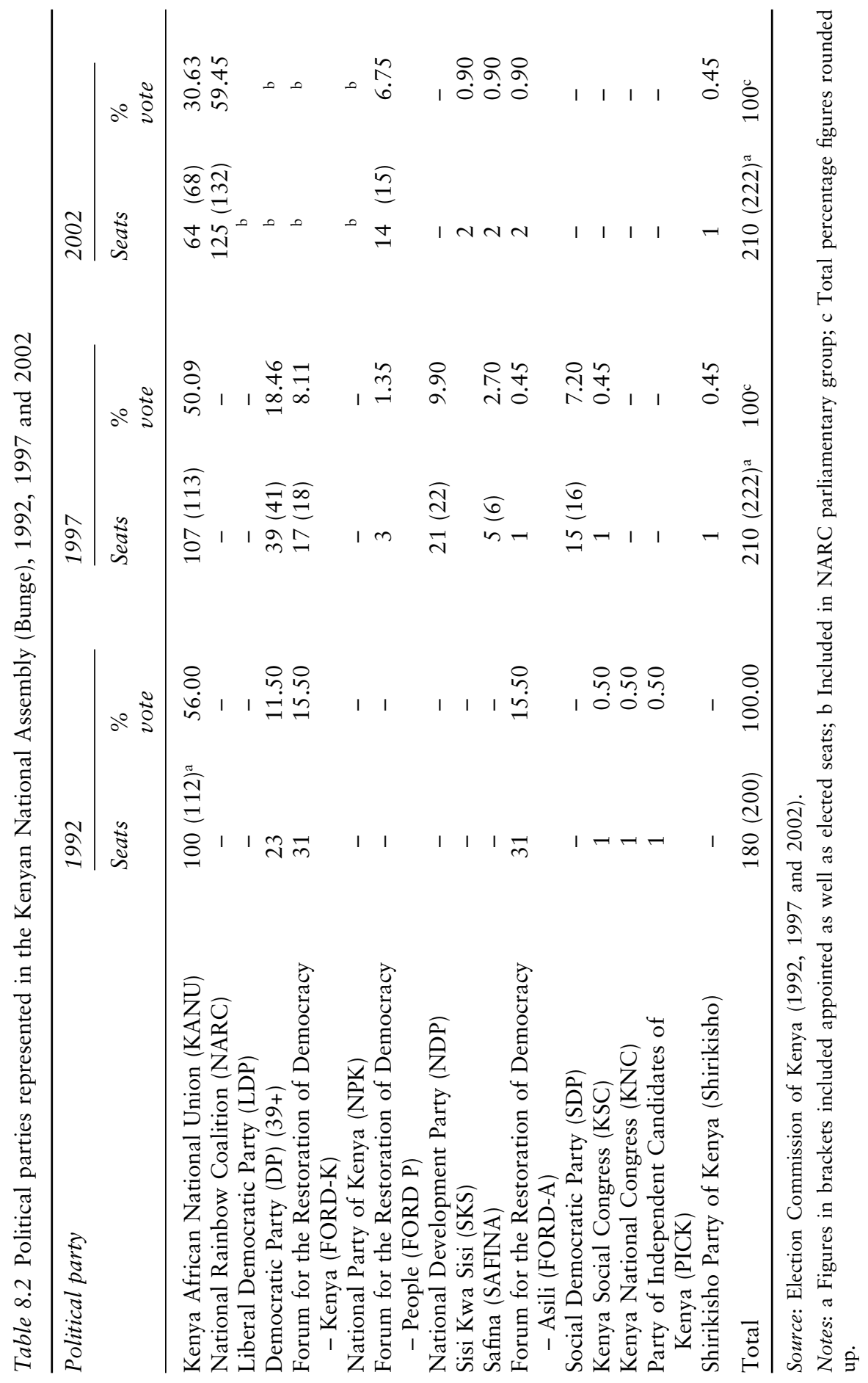




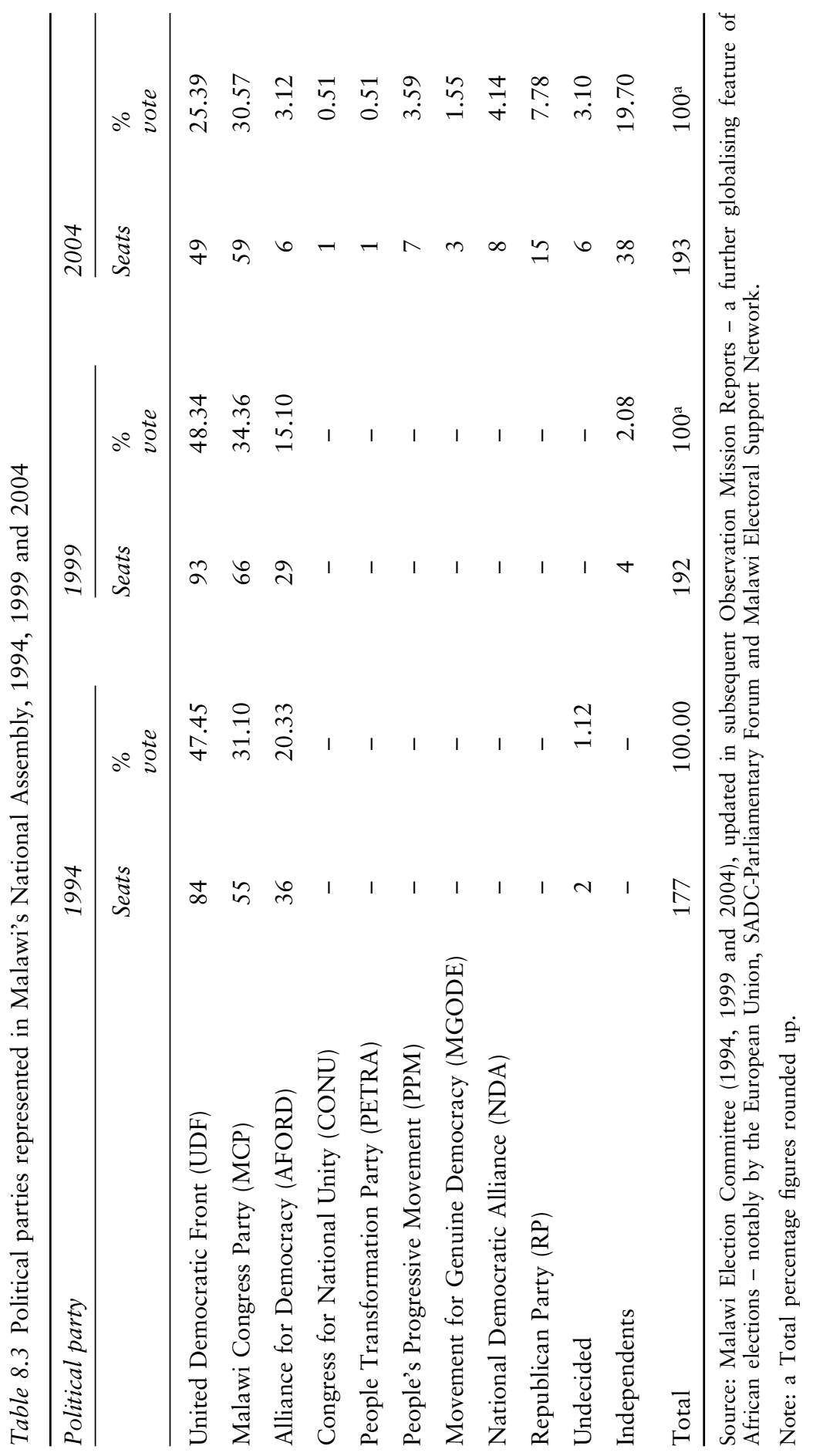


opposition political parties in Ghana and Kenya. Thus the UDF and MCP in 1994, 1999 and 2004 offered similar approaches to trade liberalisation, privatisation, public sector reforms, democracy and the rule of law, good governance (often dubbed 'anti-corruption strategies'), economic policy reforms, poverty reduction strategies, sustainable development, and gender auditing among others. However, while remaining aware of the global context within which Malawi operates, the parties in government have continued to pursue policy implementation with one eye on the need to win public support and retain or improve their electability (Englund, 2002).

In all three countries, what is significant here is not whether the parties act on their electoral pledges and manifestos - nowhere do parties implement in full all their electoral pledges - but the election pledges and party manifestos that have been made and that do inform the conduct of government. In government, African parties operate under conditions of abject poverty, high hopes and very limited resources, which can easily stifle their good intentions to act on their promises; nevertheless, there is a remarkable convergence in terms of the policies and programmes - the dearth of alternatives and absence of choice - that they offer the electorate in the economic policy domain.

\section{African parties' integration into global parliamentary and party networks}

Global democracy networks comprise two types: parliamentary and partyto-party. Both are paying-member networks - different from many of the international democracy assistance institutions that, like the German political foundations, tend to operate on a fraternal basis. Global party-to-party networks espouse direct relationships between their partner institutions and are open only to those political parties that share a similar ideological orientation. This places them outside the recent trends among some democracy assistant institutions to encourage co-operation among all parties with a view to overcoming the suspicions and hostilities found in deeply divided societies.

\section{Global parliamentary democracy networks}

The IPU is by far the oldest global parliamentary lobby network in the world. It was established in 1889, during the height of colonial expansion, as the International Organisation of Parliaments of Sovereign States, and its members today include 140 parliaments. IPU is made-up of six geopolitical groups (Africa, Asia-Pacific, Arabia, Eurasia, Latin America and the 12-Plus Group consisting of Western and Eastern European countries). Its office at the United Nations is also active in providing 


\section{2}

parliamentary hearings and organising international events. Although some members of the IPU do not adhere to liberal democracy (China, Cuba and Cambodia), in 1997 it adopted the Universal Declaration on Democracy. ${ }^{4}$ Although not actively engaged in fomenting agitation for democracy, the IPU organises activities in support of the democratic process once it is under way, and these reflect its adherence to the Universal Declaration on Democracy.

The IPU Africa group consists of 39 members; Chad, Eritrea, Lesotho, Madagascar, Malawi, Somalia and Swaziland are not members. The parliaments of Kenya and Ghana are active members of the IPU, currently represented by parliamentarians from the governing political parties. The IPU organises pan-African and sub-regional symposia on subjects such as representative democracy, international peace and security, sustainable development, human rights, education, science and culture, and women in parliament. The stated objective of these is to aid democracy and improve the quality of governance as well as enhancing worldwide parliamentary dialogue and peace through the establishment of representative democracy.

Of particular relevance to Ghana, Kenya and Malawi is the CPA, ${ }^{5}$ which is the second oldest global democracy network, after the IPU. Established in 1911 as the Empire Parliamentary Association, the CPA's members consist of 170 national, state, provincial and territorial parliaments, with about 15,000 parliamentarians. The CPA mission is to advance parliamentary democracy, enhance knowledge and understanding of democratic governance, and build an informed parliamentary community able to deepen the Commonwealth's democratic commitment and to further co-operation among its parliaments and legislatures.

There is a distinct African group within the Commonwealth called the Pan-African Commonwealth Parliamentary Group, which co-operates with the Pan-African Parliament. ${ }^{6}$ The governing political parties in Ghana, Kenya and Malawi are members. Generally, the new global context of development influences the activities of global parliamentary networks. Although parliamentary networks are mainly interested in improving the capabilities of parliamentarians and the capacity of parliaments, their activities also influence political parties. This is not only because parliamentarians represent political parties and the electorates who voted for them but also because the strong presence of parties constituting the governing majority has a strong bearing on government policy and programmes as well as adherence to democratic principles. ${ }^{7}$ With their historical antecedence and current functions, the global parliamentary networks represent an element of continuity from colonialism and imperialism to the current developments of the globalising world in which they operate. Therefore they have to cope with this dual heritage and the new opportunities it offers as part of the global governance regime. 


\section{Party-to-party partnerships and networks}

The accession of African political parties to global-party-to-party networks is a new phenomenon dating back less than two decades. It is a product of the end of the cold war and the ideological schism between East and West, the post-1990s transition to democracy and the opening up of the political space for proactive transnational political, economic and social networks. The subsequent evolution and maturation of these networks has signalled the end of the state monopoly of inter-state relations and the emergence of non-state actors such as civil society and non-governmental organisations and political party networks.

African Christian Democrats Union (ACDU), part of the International Christian Democrats Union (ICDU), is an association that consists of Conservatives, Christian Democrats or so-called 'like-minded' political parties of the centre and centre-right. ACDU activities are attended by parliamentarians representing their political parties or the youth troika of the member parties. Ghana, for example, is represented by the New Patriotic Party's (NPP) Youth Wing (NPPY) and the Ghana Liberal Students Association (GHALSA), Malawi by the Malawi Congress Party (MCP), the United Democratic Front Youth (UDFY), and Kenya by the Democratic Party (DP). The youth element is particularly significant for recruitment, internalising democratic values and preparing the next generation of democrats.

In August 1997, eleven African liberal youth organisations founded the Dakar-based Democrat Union of Africa/African Dialogue Group (DUA/ ADG) as part of the International Democrat Union (IDU). IDU member parties organised regional networks, most of which came into existence as new democracies established during the 1990s. ${ }^{8}$ The DUA/ADG provides a forum for parties with similar convictions to meet and exchange views and experiences on matters of policy and organisation, so that they can learn from each other, act together and establish contacts. More importantly, they agree on common positions to influence the direction of global policies once they are in power and speak with one voice to promote democracy and centre-right policies around the globe. Ghana's NPP, Kenya's DP and Malawi's MCP are members of the IDU. While the NPP and the MPC are the main opposition parties in Ghana and Malawi, respectively, the DP of Kenya is a member of the governing NARC. Thus parties that share similar convictions have the opportunity to meet and exchange ideas regardless of whether or not they are in government.

The Socialist International is a worldwide organisation of social democratic, socialist and labour parties. Currently, it brings together 162 political parties and organisations from all continents. Twenty-three African political parties are Socialist International members (19 full members and four observers). Although Ghana's opposition NDC is a 


\section{M. A. Mohamed Salih}

member, Kenya, which has more leftist political parties than any other African country, has no representation there. For the sake of comparison, the Green Party Federation of Africa is a member of the Global Green Federation, which consists of 800 green parties worldwide. There are 15 African Green Party members, including the Mazingira Green Party of Kenya. The general principles that bring Greens together include economic wisdom, social justice, participatory democracy, sustainability and respect for diversity and non-violence. Although the African Greens are yet to exert significant influence on politics in Africa, they have considerable solidarity with the global Green movement and its ecological campaigns against oil and mineral extraction activities, industrial pollution and rainforest logging, and its campaign for the protection of biodiversity (Mohamed Salih, 1999). However, such support has yet to translate into parliamentary seats in any of the three countries.

The Liberal International is an association of parties, groups, co-operating organisations and individuals that support and accept the liberal principles aimed at fostering the growth of a democratic society based on personal liberty, personal responsibility and social justice. The organisation provides financial and human resources for the co-operation and interchange of information between member organisations and men and women of all countries who accept these principles. Malawi's UDF is a member and it also belongs to the London-based African Liberal Network (ALN), established in 2003 by 17 African liberal political parties. It is paradoxical that, although the policies adopted by most African governing political parties have a neo-liberal economic orientation they do not openly declare themselves liberal because they fear the criticism it will attract from their political opponents. However, the UDF exceptionally does declare its adoption of liberal international principles, without which Liberal International would not accept it as a member. Similar rules on formal acceptance of the organisation's basic constitution apply to the other global party-to-party networks.

Arguably, Africa's political party integration into global parliamentary and party-to-party networks illustrates that the emergence of a third generation of African party-based democracy is now an accepted fact (the first generation being the colonial and the second a mix of one-party systems and restricted democracies of the 1990s). This generation is more confident and open to the influence of global party-to-party networks and the globalised democratic values they propagate. At least two scenarios might be envisaged. On the one hand, global parliamentary associations and political party networks, initiated by the longer established democracies will influence further the development of party-based democracy in Africa, by persuasion, training and exchange of ideas about strategy and policy. The ultimate outcome of these networks and interactions could be the creation of a global space for improved dispensation of democratic 
values. On the other hand, there is the view that the continuing presence of powerful global democratic trends and universally inspired values could deprive Africans of the opportunity to devise their own pathways to, and models of, democracy independent of such external influences. The writer's belief is that the main contribution of global democracy networks currently is the incarnation of a gentler political modernisation agenda under the guise of modernisation revisionism and a dominant neo-liberal paradigm (Mohamed Salih, 2001). Another outcome of externally driven globalised party-based democracy is the widening of the gulf between elite-dominated political institutions - which means the political parties and the parliaments - and the masses of illiterate African citizens, who will come to feel increasingly alienated by the conduct of their own society's political elite. The result of such a situation could well be widespread political apathy and, even, political withdrawal.

\section{Which aspects of African party-based democracies have not been globalised?}

The dialectical 'other' of what is globalised refers to what is not globalised about African party-based democracy. Here, three aspects stand out: the ethnic nature of political parties; the persistence of scaled-up patronclient networks; and the absence of internal party democracy.

\section{The ethnic nature of African political parties}

Generally, African political parties remain ethnic in nature, created, organised and dominated by an educated elite, who exploit them to contest elections and maintain control over the resources, personnel and the policy of government (Mohamed Salih, 2001; Posner, 2004). Two characteristics are common to the majority of African party-based democracies. First, the political parties tend to be elitist, based on non-democratic structures and organisation, with irregular contacts between the leaders and their electoral base. Contacts among party committee members are superficial due to the top leadership's control over party management. The educational gap between party leadership and functionaries also inhibits party members from voicing their concerns or having their concerns taken seriously. Political contact with the electorate happens only periodically, with the highest level of intensity during election campaigns.

Second, the majority of party members are politically illiterate (not aware of the ideological bases on which modern political parties are founded, that is liberal, social democratic or republican) and lack experience of how democratic institutions operate. In the circumstances, ethnicity provides a strong ideological foundation based on ethnic systems of belief, political values and culture. 
If, globally, political parties are institutional mechanisms for capturing and maintaining power, and elections are the institutional mechanisms through which parties compete for power, then Africa's parties are no different. They engage in elections as institutionalised political activities in which citizens exercise their sovereign will in choosing their representatives, who eventually form or select the personnel and policy of government. Also, in common with global democratic values, elections facilitate the orderly transfer of power according to the will of a sovereign citizenry. However, a characteristic of African political parties that distinguishes it from most Western counterparts is the visible presence of ethnicity in their inclinations or orientation. In fact, the influence of ethnicity in the parties in Ghana, Kenya and Malawi has become more apparent with the onset of democratic rule, as ethnic groups have sought to protect and advance their interests through the medium of regional political parties. Table 8.4 shows the association of political parties with region and ethnicity in the three countries.

For example in Kenya the major trend suggests voting on ethnic lines although with a few exceptions often influenced by the extent of linguistic and cultural similarities shared by the dominant ethnic groups. The same applies to Malawi's Northern, Central and Southern regions. The UDF dominated in the Southern region and was able to encroach into MCP territory in the Central region. AFORD also shared Northern region votes with the UDF. However, although the whole population identifies itself as northerners ('wakumpoto'), in reality they belong to diverse ethnic groups, mainly the Chakufwa, Chewa, Nyanja, Tumbuko, Yao, Lomwe, Sena, Tonga, Ngoni, Ngonde (Chirwa 1994; Kalipeni 1997; Kamwendo 2002). Similarly in Ghana the NDC enjoys strong support from the Akan/Ewe and the Ga-Adangbe but also enjoys the support of a variety of smaller ethnic groups, while the NPP has been unassailable among the Ashante, Fante and Akuapem.

Interestingly, all presidential candidates during the most recent presidential elections in Ghana, Kenya and Malawi gained a majority of their votes from their own ethnic group constituencies. The potential implications for the formation of government, distribution of ministerial positions and chairpersons of parliamentary committees are very serious. At the very least it has contributed to venomous criticism of the governments of the respective presidents, citing nepotism and corruption as major problems besetting governance. Where members of the same ethnic group routinely vote for one ethnic or regional political party only, the ethnic groups assume some permanence, and the elites who manipulate this arrangement also acquire a permanent foothold in inter- and intra-ethnic politics. For the African electorates, it is ethnic groups, and not modern Western ideology, that have become the ideological markers for a political leadership devoid of the concept of the circulation of elites, which has been central to Western 
Table 8.4 Ethnic character and voting behaviour of major political parties in Ghana, Kenya and Malawi

Major political party, coalition or elite pacts

\section{Ghana}

New Patriotic Party (NPP)

National Democratic Congress (NDC)

\section{Kenya}

National Rainbow Coalition (NARC)

Kenya African National Union (KANU)

Forum for the Restoration of Democracy - People (FORD-P)

\section{Malawi}

United Democratic Front (UDF)

Malawi Congress Party (MCP)

Republican Party (RP)

Alliance for Democracy (AFORD)

\section{Ethnic or regional support}

\author{
Ethric or regional support
}

Largely Ashanti, Akuapem and Fante; also won votes in some NDC strongholds in the north.

Akan/Ewe, Ga-Adangbe; also gained support from a variety of smaller ethnic groups.

Substantial support from the Luo ethnic group. Luo educated political elite forms the majority of ministers in the NARC government, including President Kibaki.

Alliance of small ethnic groups with substantial Kikuyu support for Uhuru Kenyatta, son of Jomo Kenyatta (the first president of independent Kenya), a failed presidential candidate in 2002 elections.

The only strong remaining faction of FORD 1992, which was created by Oginga Odinga (Luo and various ethnic groups from the Nyasa, Central, Western and Rift Valley Provinces).

Southern region (Yao), with MCP encroachment in some constituencies (Chewa).

Central and adjacent Northern region: mainly, Chewa, Nyanja, Tumbuko, Yao, Lomwe, Sena, Tonga, Ngoni, Ngonde.

Dominant in the Northern and Southern regions (Yao and mainly Tumbuko ethnic groups); gained votes from some ethnic groups in the north loyal to the MCP and AFORD. Also encroached on UDF constituencies in the south.

Northern region: Tumbuko, Tonga and Chakufwa ethnic groups, strong rivalry with the MCP.

Sources: Compiled by the author from various sources, in respect of constituency/district and ethnic groups' voting behaviour. 
thinking about party-based democracy. This African phenomenon has also entrenched the line of patronage and contributed to the poor record of internal democracy inside Africa's political parties. In the very worst cases it has fuelled violent ethnic conflict, where party-based democracy had expanded the terrain of ethnic competition. ${ }^{9}$ Conflict then tends to harden ethnic boundaries and further strengthen the relationship between elite and ethnic groups: in short, a vicious circle.

\section{Patron-client relationship}

An important feature wherein party-based democracy has not been globalised is the strong presence of client-patron relations between party leadership and party operatives. Political party tycoons and oligarchies create patronage relations through financial 'kick backs' in order to secure central government support and mobilise political support at the local level. In this sense, a client-patron relationship is fundamentally a relationship of exchange in which the client also provides support for the patron (Clapham, 1985: 58-9). As if the troublesome presence of ethnic divisions is not complication enough for African democratisation politics, Berman (1998) traced the linkages between ethnicity and patron-client networks to colonial rule grounded in the latter's alliance with local chiefs. According to Berman (1998: 305), 'patron-client networks remain the fundamental statesociety linkage in circumstances of social crisis and uncertainty and have extended to the very centre of the state'.

Also, Tangri (1999) among others has shown that the politics of patronage seeps through state-private sector relations as a facilitator of access to resources and economic opportunities, even when the state in principle responds positively to globally sourced neo-liberal economic policy designs, such as privatisation. But globalisation has transformed local level leaders or chiefs and their subjects' patronage relations in the sense that such traditional authorities are becoming increasingly impoverished materially and excluded from power, unable to respond to the demands of modern politics. At best they now play an intermediary role between the central elite and the voters rather than command significant power resources themselves. They will use their proximity to the grass roots of society to deliver votes to presidential or parliamentary candidates in exchange for financial and other types of support. In this way, patronage still does benefit some chiefs and a few other individuals among different ethnic groups, but many are left out. While opposition politicians and governments trade criticisms over one another's capability to fulfil the 'good governance' conditionalities that are indicated globally by the international financial institutions, African polities have witnessed the growth of new patronage arrangements connecting those very financial institutions on the one side and on the other, their 
ruling political parties who determine public policy and the dispensation of government resources.

\section{Internal party democracy}

Internal party democracy - in respect of the selection of candidates, leadership contests, regular membership conventions, and internal rules to discipline party leadership and hold it accountable to party members - is in short supply in all major political parties in Ghana, Kenya and Malawi. Invariably, a core of members in small committees decides party affairs and policy. African political parties are not democratic; they exclude ordinary, mostly uneducated people from the political process, are elitist and non-transparent. In the case of some parties that have gained power, nonelected but wealthy and powerful members have made a bid to control the party, and where successful the outcome is an executive with little real accountability to legislative or wider political checks and balances.

Without exception the political parties in Kenya, Ghana and Malawi do not engage in regular and periodic consultation with the grass roots. And although the situation differs from one African country to another, it is quite usual for 'absentee' party representatives and committee members to surface for the purpose of mobilising voters during election times only, avoiding visiting their constituencies between election campaigns. The internal party structures also lack accountability and transparency in matters of party finance. Despite the fact that many countries have developed legislation to regulate party financing (donations, election campaign expenditures and audit of political party accounts), financial exchanges are often difficult to verify, and can involve hidden interactions between those whose support for a party rests on its purported political beliefs, those who expect a financial payback and those who are merely pursuing their own personal political ambitions. Invariably just a small group of individuals, business entrepreneurs, foreign donors, party-to-party networks and fraternal organisations are relied on for funding party activities. In many cases the same individuals have taken part in politics over many years dating back to the period of one-party rule, subsequently defecting from the ruling party and in some cases establishing their own party. Others were released from their ministerial duties, or disagreed with their former political mentors and then joined the opposition. ${ }^{10}$ But in most cases the personal wealth of the leader at best, or the public coffers at worst, has accounted for their capacity to run election campaigns and, often, lead lavish lifestyles as well. In such circumstances, the party leader becomes the party boss with unquestioned authority over party committees, policies and decisions (Mohamed Salih, 2005). However, it can be argued that the institutionalisation of greater intra-party democracy in Africa's parties will be contingent on the maturation of civil society 
and the ability of civic associations to exert influence on parties from the side (Chiroro, 2005: 2).

\section{Conclusion}

African party-based democracy acquires its meaning from the influences of global governance, which have shaped the current wave of multi-party democracy and the new global context within which political parties operate. In common with political parties in other parts of the world, African political parties are well aware of their position in the geopolitics of development, which characterises their political programmes and policy orientations.

In the new global context of development, political party discourses, programmes and relations with the electorate straddle the contours of the globally informed neo-liberal economic paradigm, albeit with local variations and without formally barring parties and civil society activism with a vocal anti-globalisation message from emerging. This is no different from other parts of the world where the challenge to neo-liberalism comes from the very democratic forces that it has unleashed.

Globalised party-based democracy does not mean universalised partybased democracy. That is, African political parties subscribe to the broadly defined global paradigms reflected in their political manifestos without becoming fully Westernised. Evidently, there will always be points of convergence and divergence between globalised and localised forms of political engagement. African political parties also exhibit some elements of localised or national political culture, such as the absence of internal party democracy, persistence of patronage arrangements and strong party affiliation with ethnicity, religion or region, which alert us to the fact that African party-based democracy has, generally, retained the form but less of the content of Western party-based democracy.

Regardless of their ambivalence towards internal political party democracy and the knowledge that they exhibit quasi-polyarchical characteristics, African political parties have successfully canvassed considerable human and financial resources, both from abroad and at home. They are also able to maintain themselves as political organisations with a set of broadly defined values, mobilise popular support, and win and lose elections, as well as form and, in a few cases, initiate motions of no confidence in government. Measured by these formative political party characteristics, African political parties are part of a globalising party-based democracy because they generally assume universal political party functions - or have become quasi-polyarchical.

In addition, global party-to-party and parliamentary networks are promoting party-based democracy, in a bid to bring Africa as well as other developing countries into conformity with the ethos and core values 
of 'Western' party-based democracy. Generally, bilateral and multilateral democracy promotion institutions promote global democracy with the aim of strengthening democratic institutions, including, of course, national parliaments and political parties in issues such as the rule of law, good governance and other aspects of state-building. Given these external interventions and the conditionalities that come from dealing with the global financial institutions, it is doubtful that Africa could develop political norms, values and institutions of party-based democracy radically different from those of the established Western mature democracies. But this has not prevented Africa's parties from retaining much of their own ethnically inclined and other distinctive institutional arrangements that occupy the middle ground between globalisation and localisation.

\section{Notes}

1 Most notably, there were civil wars in Angola, Chad, Ethiopia, Mozambique, Nigeria, Somalia, Sudan, Uganda and more recently in Sierra Leone, Liberia and the Democratic Republic of Congo.

2 'Polyarchy' is used because much of the current jargon on 'good governance' was rehashed from this notion and, in most cases, without even referring to it, although Robinson, 1996 is a notable exception.

3 As the initial success of these policies waned between 1997 and 1999 Kenya's Enhanced Structural Adjustment programme was introduced with the aim of revitalising economic policy reform, reforming the civil service and strengthening anti-corruption efforts.

4 This was at the 161st session, held in Cairo, 16 September 1997. The United Nations General Assembly adopted the Universal Declaration on Democracy in its 51st session on 20 December 1996. Article (1) of the Declaration states: 'democracy is a universally recognised ideal as well as a goal, which is based on common values shared by peoples throughout the world community irrespective of cultural, political, social and economic differences. It is thus a basic right of citizenship to be exercised under conditions of freedom, equality, transparency and responsibility, with due respect for the plurality of views, and in the interest of the polity.'

5 The Constitution of the Commonwealth Parliamentary Association was adopted in Cyprus in 1993 and revised in Canada in 2004. The author held interviews with African parliamentarians involved in the Ghana Workshop to Strengthen Legislatures in West Africa, Agona Swedru, 11-14 February 2005.

6 Pan-African Parliament (PAP) and four sub-regional parliaments - the East African Legislative Assembly; Southern African Development Community (SADC) Parliamentary Forum; the Economic Community of West African States - Parliament (ECOWAS-P); and the Maghreb Union Assembly (UMA) - provide Africa's regional and sub-regional parliamentary networks.

7 The suspension at various times of Nigeria, Zimbabwe, Fiji and Pakistan from the Commonwealth when they reverted to military or similarly authoritarian rule is illustrative. The CPA used its political clout to discipline members.

8 Other African parties belonging to IDU are: Cape Verde (Movimiento para la Democracia (MD); Cameroon (Democrat Progressive Party of Cameroon); Congo (Brazzaville) (Movement for Democracy and Solidarity); Congo (DR), (Democrat and Social Christian Party), Mauritania (Union pour la Démocratie 


\section{M. A. Mohamed Salih}

et le Progress (UDP) Party); Mauritius (Democratic Union of Mauritius) and Madagascar (FANORENANA). Three observer parties are from Morocco (Istiglal [Independence] Party), Mozambique (Mozambique National Resistance) and Uganda (Democratic Party).

9 For the association between democratisation and ethnic conflicts in Africa see Glickman (1996).

10 President Kufuor of Ghana was Member of Parliament and Deputy Foreign Minister in 1969; President Kibaki of Kenya was Vice-President (1978-88); and Bakili Muluzi, the first President of Malawi during multi-party democracy, was Minister of Education (1976-77) and Minister of Transport and Communication (1977-81). 


\title{
9 Party assistance and the crisis of democracy in southern Africa
}

\author{
Roger Southall
}

The end of the cold war was to bring about significant changes at the political level in Africa. No longer prepared to prop up dictatorial regimes that had served their strategic interests in a battle against communism, Western powers now turned their attentions to the promotion of 'democracy and good governance' as an accompaniment to the neo-liberal 'structural adjustment' programmes of economic reform that they had been imposing upon client states since the 1980s. The prodding of oneparty and military governments into moving towards competitive multipartyism consequently became increasingly central to donor countries' activities from the early 1990s, with the logic of such 'democracy assistance' requiring that recipient countries redesign their political institutions to reflect the liberal-democratic values that now became the global referent. The outcome was uneven, not least because many countries in Africa remained mired in internal conflict and vicious wars. Nonetheless, there was a broad shift throughout the continent towards democratisation, not least because the opponents of incumbent regimes took good advantage of the increased political space to challenge governments, and in a substantial number of cases, to displace them by defeating ruling parties in competitive elections (see Chapter 8). Yet donor-driven reform programmes do not always work out as originally intended. Hence, while democracy assistance in Africa has sought to steer diverse countries towards competitive multi-partyism, the new rules of the game have been simultaneously manipulated by governments to consolidate their support: the universalising norms of liberal democracy are thus now utilised to buttress distinctly illiberal regimes. Meanwhile, the continent faces a new challenge in the form of the renewed interest of global powers in Africa's resources, notably of oil, energy and minerals, the scramble for which may overwhelm the aims and objectives of 'democracy assistance'.

This chapter illustrates the argument above by reference to southern Africa. This focus has been selected for two reasons. First, southern Africa is the region within which the shift to democratisation was most pronounced. Second, a set of recent studies of political parties and democratisation across the region that has been conducted by the Electoral 


\section{Roger Southall}

Institute for Southern Africa allows for systematic comparison. Nonetheless, although regionally bound, the thrust of the argument is likely to have a much wider relevance.

\section{The crisis of democracy in southern Africa}

The author has argued elsewhere that there is a developing crisis of democracy in southern Africa which is characterised, first, by an increasingly explicit clash between an authoritarian culture of national liberation and hopes for participatory democracy and, second, by a closely related model of state power which, even if obscured under democratic garb, entrenches elites and promotes highly unequal patterns of accumulation and development. The argument was illustrated by reference to developments in Namibia, South Africa and Zimbabwe. It proposed, first, that 'once having attained national independence, the inexorable logic of national liberation seems to be to suppress rather than liberate democracy' (Southall, 2003a: 256). This means that while having 'created' nations among peoples struggling against the oppressions of colonialism, victorious ruling parties now strive for a monolithic national unity that tends to denounce unwelcome ethnic, social, cultural or political diversity, often in racialised or xenophobic terms, in the interests of constituting their countries into dominant-party states under their own hegemony. It also means that having captured state power, national liberation movements tend to promote a culture in which opposition to established leadership and its ideas is regarded as both illegitimate and reactionary. And finally it means the deeply rooted legacies of inequalities in post-colonial societies have lent themselves to regime-driven accumulation strategies pursued by the new political class, which can easily be disguised as the pursuit of a much wider social equality.

The author's second major contention, following Good (2002), was that while many advances have been made since 1990, the globalising liberal democratic model that has been implanted, revolving around periodic elections, has allowed elitism and inequality to increase. Voting for governments and politicians is absolutely necessary, yet it is also manifestly insufficient as a means of empowering citizens to control elites. Hence, ordinary people are becoming increasingly disillusioned with electoral democracy, which has done little or nothing to improve their material comforts yet leaves autocratic elites untouched. Indeed, Good (2002) views the liberal democracies of southern Africa as all uncomfortably alike, even if countries such as Namibia and South Africa present far more amiable faces to the world than the one provided by contemporary Zimbabwe. All three regimes operate through dominant parties, centralising presidencies and the limitation of opposition. Protests about human rights violations and the abuse of constitutions in neighbouring countries are suppressed out of respect for their governments' 'sovereignty'. 
This perspective does not deny the forward momentum brought about by the successful conclusion to national liberation struggles, by the move to peace in such previously conflict-torn countries as Angola, Mozambique and the Democratic Republic of Congo (DRC), by the replacement of authoritarian one-partyism or military rule by multi-partyism in countries such as Tanzania and Lesotho and, of course, by the establishment of post-apartheid South Africa as a constitutionally established democracy. Furthermore, it attempts to acknowledge the considerable historical and situational variations that provide for differential democratic deficits and prospects across the countries of southern Africa. Certainly, the writer has argued elsewhere that 'party dominance' in South Africa is to some extent constrained by an alternative internal party tradition of debate, constitutional limitations and limited capacity of the state to 'impose itself upon society' (for instance Southall, 2001). Furthermore, the tendencies identified here are determinate and may well summon up counter-movements.

However, while these observations are applicable to most of the countries of southern Africa (the authoritarian kingdom of Swaziland being an obvious exception), the principal divergences from the model occur in 'second generation democracies' such as Zambia and Malawi. There, long-ruling nationalist parties were displaced by oppositional challengers in the early 1990s. The latter have proved hitherto unable to establish their political dominance and rely very much upon state power to defend their fragile control. Nonetheless, despite such qualifications, it can be argued that while the national liberation movements and the ideas, institutions and implementations of electoral democracy were harbingers of greater freedoms for the large majority of people(s), they simultaneously carry the seeds of their own negation. This is especially so when they are associated with a present trajectory of capitalist development within contemporary Africa that remains heavily centred around free market strategies encouraging a 'new scramble' for resource extraction and the attraction of foreign rather than the mobilisation of domestic capital and savings. This clearly poses major questions about the nature of democracy assistance within the region as a whole.

\section{Democracy assistance in southern Africa hitherto}

According to Carothers (1997), the basic strategy pursued by recent US democracy assistance programmes has consisted: first, of promoting the capacity of countries to hold free and fair elections; second, of assisting with the democratisation of governing institutions, the adoption of constitutions providing for political representivity, accountability and human rights, promoting judicial reform, and enabling parliaments to become more effective; and third, of strengthening civil society, notably those NGOs that are advocacy-oriented (such as human rights bodies and 


\section{Roger Southall}

election monitoring groups), as well as supporting trade unions and promoting media development. Most of the other actors involved in the globalising project of democracy assistance operate from basically the same menu.

Among these actors, Western political foundations and think tanks are prominent as part of what Scott (1999) calls a 'transnational democracy issue network'. Political foundations, of which the foremost in southern Africa are the German Stiftungen (see Chapter 10), Scott describes as established by, but semi-independent of, states. They serve to connect state actors with a multi-centric world, whereas think tanks (such as the Carter Center in the US) are independent, and stand apart from the NGO sector while serving to link them to states. While there are important distinctions between them, their key activities fall into four categories: first, they make grants for activities directly supportive of democracy; second, they fund and engage in analysis of democratisation with a view to advocating specific policies; third, they facilitate interaction among democracy-oriented groups; and fourth, they engage in active democracybuilding via such activities as training political parties and NGOs, and monitoring elections. While such efforts are generally mutually reinforcing and advance a broadly consistent form of liberal democracy, Scott concludes that the most significant consequence of their activities is the 'transnational norm-building' which serves as a modifier of states' sovereignty by specifying 'proper' - that is, globalising Western liberal democratic - norms of behaviour.

Such general profiles provide a good summary of the universalising thrust of democracy promotion work in southern Africa in recent years. However, they fail to speak to the particular history whereby the liberation movements, trade unions and civil society organisations of the region were subject to strongly partisan assistance by competing aid-givers who in many cases had contrary agendas.

The complicity of major Western governments, multinational corporations and conservative parties and organisations in the maintenance of white supremacy and apartheid in southern Africa is well known. Basically, such actors took a strongly hostile stance to the liberation movements that were engaged in armed struggle and that could conveniently be denounced as Marxist. In contrast, because these Western governments and their associates were compelled to decry colonialism, white supremacy and apartheid (often even while lending them covert support), their initial 'democracy assistance' favoured southern African political parties, NGOs and other actors that, of a liberal if not conservative persuasion, argued against armed struggle and economic sanctions, favoured constitutionalism and argued that capitalist development would erode political oppressions over the long term. Meanwhile, they justified their stance by reference to the fact that liberation movements such as the African National Congress of South Africa (ANC), Zimbabwe African National Union (ZANU) and 
the South West African People's Organisation (SWAPO) received direct support from the regimes in Moscow and Eastern Europe or in Beijing. To some extent, of course, this stance was counterbalanced by the more enlightened positions of the Scandinavian governments, which lent direct support to the liberation movements (Sellstrom, 2002), by the international trade union movement, which assisted the development of democratic trade unions (Southall, 1995), and, of course, by the international antiapartheid movement, a conglomerate of organisations and popular movements that provided strong solidarity support to the various liberation movements. These latter strategies contributed to the growing strength of pro-democracy forces, which by the mid 1980s began to render South Africa 'ungovernable'. Subsequently, therefore, Western donors began to see NGOs as increasingly legitimate vehicles for channelling funds to victims and opponents of apartheid, one estimate suggesting that the European Commission alone directed some 2 billion rand - 11 rand was the equivalent of approximately $£ 1$ in 2006 - to such bodies between 1986 and 1991, by far the largest amount given to any single country in the region in that period (Masterson and Letsholo, 2005: 85).

Following the triumph of the various liberation movements and their move into government, democracy assistance activities have been overwhelmingly directed towards the consolidation of multi-party democracy via support for elections, the strengthening of parliaments, and the encouragement of relevant civil society organisations. A review indicates a familiar set of activities.

\section{Donor conditionality linked to 'good governance'}

Donor pressure for market reforms to state dominated economies has been strongly linked since the early 1990s to pressure for political liberalisation, multi-partyism and 'good governance'. In some cases - notably that of Tanzania, whose return to multi-partyism in 1995 was partly prompted by ruling party fears that other donor aid would be affected if it did not introduce political reform (Karume, 2004a: 42) - this was indirect, but more usually it has been direct, with Zambia, for instance, becoming one of the largest recipients of donor aid in Africa in 1991 in return for making an early exit from one-partyism to multi-partyism. However, as the new government of the Movement for Multi-party Democracy (MMD), which won the 1991 elections, became more authoritarian and corrupt, donors increasingly began to link their aid to 'good governance'.

Zambia's move to multi-partyism was viewed as a pilot project, and donors wanted to demonstrate, through extensive support, the benefits of democratisation (Karume, 2004b: 42). The persuasiveness of donors was assisted by the fact that some countries in southern Africa are among the world's poorest and hence among the most heavily dependent on external aid: at the present time, for instance, Malawi (which returned 


\section{Roger Southall}

to multi-partyism in 1993) is dependent on aid for more than 35 per cent of its recurrent budget and for around 90 per cent of its development budget (Kabemba, 2005: 50). Similarly, although donor interest in Lesotho (which transited from military rule to multi-partyism in 1993) has always been low, the government receives more than half its national budget from foreign funding (Kabemba, 2003: 40). Meanwhile, a positive association between conditionality and democratisation is suggested by a weak donor presence in Swaziland, where political parties are banned; total external assistance to that middle-income country stands at below 5 per cent of GDP (Kabemba, 2004: 35). In Zimbabwe, democracy aid packages in the early 1990s were directed not so much at stimulating political changes but at increasing the efficiency of state institutions, good governance and electoral administration. However, the current crisis has resulted in many donors reducing their assistance to government, pulling out completely or redirecting it to humanitarian aid or assistance for civil society. It now stands at around 15 per cent of Zimbabwe's GDP. While the connection between donor assistance and democratisation is more complex than this, it is worth noting the observation of a local commentator: 'without donor assistance one can forget about democracy in Malawi' (cited in Kabemba, 2005: 51).

\section{Electoral process assistance}

Support for 'free and fair' elections has been central to democracy assistance in southern Africa. Very direct support for the establishment of an independent electoral commission and the framework of elections was offered by the Commonwealth, European Union and national donors in Lesotho in 1993. This set the scene for the much more extensive operation that was undertaken in South Africa in that country's first democratic election in 1994, when major funding was directed to assisting the electoral process: the USAID alone expended US $\$ 250$ million on those elections, compared with the US\$100 million that it spent on the Angolan elections in 1992 and the total of US\$15 million it spent on the elections in Botswana (1994), Lesotho (1998) and Malawi (1994) (Masterson and Letsholo, 2005), although most certainly in South Africa's case the bulk of such expenditure was directed at civil society rather than the official electoral machinery. Considerable aid was devoted to voter education and, of course, to electoral monitoring, which rapidly established itself as a standard feature of the African electoral landscape (Daniel and Southall, 1999). Subsequently, however, donor assistance to elections has become more carefully calibrated to individual situations.

First, where possible, there has been a tendency for electoral process assistance to become indirect, with donors urging governments to demonstrate commitment to democratisation by taking financial and other 
responsibility for their own electoral bodies. Thus international financial support to South Africa's Independent Electoral Commission (IEC) has declined from 24.2 million rand in 1994 to 6.6 million rand in 2004, with the international community deciding that South African elections are now so well established and fairly run that they no longer need a significant presence of international monitors. Similarly, the cost of the elections on mainland Tanzania that was covered by donors fell from a third of the total incurred by the National Electoral Commission in the 1995 elections to 14 per cent in 2000. Meanwhile, the electoral commission in Botswana has long remained overwhelmingly funded by its own government, donors not only deeming that country sufficiently wealthy to do so but also presenting it as a beacon of democracy.

Second, assistance for elections has remained extensive in countries that are too poor to bear the full costs themselves and where the electoral process continues to be fragile. Hence Lesotho's elections of 1998 and 2002 remained heavily dependent financially and logistically upon external assistance (US $\$ 2.8$ out of a total of US $\$ 4.4$ million of democracy assistance funding was devoted to electoral administration alone during the period 2001-03) (Kabemba, 2003: 42). And donors' enthusiasm for yet another new start in Zambia in the elections of 2001 (alongside, doubtless, the government's bankruptcy) led to the electoral commission receiving substantial donor funding (22.4 billion kwacha out of a total of 89 billion kwacha) for the first time (Karume, 2004b: 44). The Malawi elections of 2004 were also largely financed from external sources (US\$5.5 million out of US\$7.4 million final expenditure) (Kabemba, 2005: 52).

The third approach seeks to use electoral assistance (or its withdrawal) strategically where the freedom and fairness of the electoral process is in severe doubt. It therefore often runs up against the hostility of local governments that view their independent control of elections as an expression of their sovereignty. There are presently three flashpoints in the region in this regard. One of them is Swaziland, where donors responded generously to the holding of elections in 1993 following a review of the electoral system. Although the amended tinkbundla system remained indirect, continued to exclude political parties and was still dominated by the chiefs, there was hope that it constituted a step towards democratisation. However, donors were rapidly disabused of such notions, and their aid came to a virtual halt in subsequent elections (donors preferred to direct their attentions to a promised constitutional review) (Kabemba, 2004). A second case is provided by Zanzibar, which although part of Tanzania, possesses its own Electoral Commission (ZEC). This oversaw a highly controversial election result in 1995 featuring a victory for the ruling Chama Cha Mapinduzi (CCM). Donors suspended almost all aid in response to the resulting popular upheaval, and provided no support whatsoever for the following elections in 2002. However, following the signing of a peace agreement (the Muafaka Accord) between the opposing 


\section{Roger Southall}

parties in 2001, donors were expected to make generous contributions towards the holding of the elections in October 2005 (Karume, 2004a). The third case is Zimbabwe, one aspect of whose political crisis has been the systematic subordination of the electoral machinery to the government of Robert Mugabe. The various electoral bodies are now entirely financed by the government, and donor aid has been directed towards electoral observation and to the support of credible NGOs. However, given that such aid has incurred retaliatory action by the government, at least one donor, the UK's DFID, has temporarily stopped all its democracy programmes in favour of overtly humanitarian interventions. Any such financial leverage as remains therefore presently lies in the hands of multilateral organisations, notably the United Nations Development Programme, a body that the government views as less susceptible to the machinations of Western imperialism.

\section{Support for conflict resolution}

Conflict management is an important responsibility of authorities in a region where political violence results from perceived injustices and systematic inequalities generated by governments. The very logic of democratisation is designed, in part, to establish a system of government in which conflicts between opposing political groups can be resolved peacefully. Traditionally, democracy assistance in the region has been directed towards prodding enemies to institutionalise their hostilities: for instance, the arrival of the UN and later the European Community (EC) and the Organization of African Union observers at a key moment during the South African transition (after the Boipatong massacre and the Bisho killings in 1992), when negotiations had broken down, signalled that the international community was determined that both sides should resolve their differences. As elections themselves are devices for managing political competition, the bodies that administer them necessarily take on conflict management. Some, such as Botswana, have done so relatively successfully (Sebudubudu and Osei-Hwedie, 2005: 25-7), but others have not, and have accordingly been constrained to accept external help.

The most dramatic instance concerns Lesotho, when in the wake of the opposition parties riotously disputing the outcome of the 1998 election, South Africa backed mediation with military intervention, and thereafter - with critical international donor backing - prompted adversaries into negotiating an acceptance of a mixed member proportional electoral system. In replacing the existing first-past-the-post system and providing for fairer political representation, this laid a basis for a more legitimate electoral outcome in 2002 and subsequent political stability (Southall, 2003b).

In contrast, Commonwealth shuttle diplomacy between the CCM and the opposition Civic United Front (CUF) after the 1995 election in Zanzibar 
is judged to have failed precisely because the CCM saw the negotiations as donor driven. It was only after the conflicting parties met face to face, in a process that had committed backing from Tanzania's political leadership, that the parties concluded the Muafaka II agreement allowing for substantial reforms to electoral law and administration. Even so, there were repeat protestations concerning electoral unfairness by the CUF following the elections in October 2005. Yet the greatest challenge lies ahead in Zimbabwe, where South Africa's 'quiet diplomacy' has been as ineffective as Western pressure has proved counterproductive, and where future mediation may well have to be provided by the UN.

\section{Support for parliaments}

Recent studies of parliaments in southern Africa, conducted on behalf of the South African Institute of International Affairs, provide ample evidence that while these bodies in many ways perform admirably in difficult circumstances, they face numerous challenges. In most countries, parliamentary procedures are subject to the dictates of dominant parties; oppositions are weak, unskilled and unable to hold strong executives to account; committee systems tend to be ineffective; Members of Parliament (MPs) lack information, research capacity and have limited law-making expertise; civil society and the public generally have inadequate access to parliament. All parliaments display a massive gender imbalance (even though South Africa has one of the highest proportions of women in parliament in the world). And at least in some countries, MPs have irregular contact with their constituents or voters, and are regarded as prone to corruption. Not surprisingly, there are a variety of donor initiatives designed to address such weaknesses, the major criticism of them being that their efforts, where they do not induce a sense of dependence, make relatively little impact. In such circumstances, democracy assistance can only be somewhat hopefully addressed to the long term: in short, it is a Sisyphean task.

\section{Support for civil society, the media and women's political participation}

Support for NGOs and unofficial media has become a staple of official democracy assistance, in large measure because donors wish to compensate for the lack of effective constraints imposed upon dominant party governments by what are typically weak, divided and multiple opposition parties. Southern Africa's second wave of independence, from the Zambian election of 1991 onwards, featured the arrival in power of a number of political parties that had either grown out of, or enjoyed the massive support of, civil society organisations. Most of these had emerged to combat authoritarianism and the deprivations imposed upon populations 


\section{Roger Southall}

by structural adjustment programmes. Typically they were funded by donors to undertake activities concerned with human rights, voter and civic education, election related conflict management, consideration of electoral reform, election monitoring, promotion of political participation by women, and so on.

The extent of support offered to anti-apartheid and pro-democracy organisations in South Africa before 1994 may have been exceptional, yet it was otherwise not atypical. The EC donated about 2 billion rand between 1986 and 1991 to South African NGOs, by far the largest amount of money given to such organisations in any country in the region in that period. Indeed, Masterson and Letsholo (2005) claim that around 5,200 out of some 10,000 NGOs that existed in 1994 were completely dependent upon the assistance of private and international donor support. Although the onset of the negotiation process and the preparations for the first democratic elections saw a significant shift of funding away from civil society organisations to political parties and the IEC, NGOs involved in democracy work continued to receive substantial funding. International donors also worked closely with the new government to bring about amendments to the tax laws, which, under the apartheid regime, had severely hindered civil society. However, for all that a much larger number of NGOs qualified for significant tax exemptions, many of them continue to rely upon external funding of projects related to democratic governance.

This continuing high level of dependence of civil society organisations upon donors is replicated throughout the region. There are widespread complaints that the agendas of NGOs are dictated from outside, that recipients are tied to procurement and other conditions that vary markedly between donors, and that the programmes of the different donors often conflict. There is also concern that civil society organisations will become primarily accountable to the international community rather than to their local society. Only recently have civil society organisations in Tanzania started to mobilise local citizens to pressure their government rather than appealing to donors as guardians of democracy (Karume, 2004a: 62).

In countries that are perceived as broadly democratic, donors are generally anxious that their assistance should be seen as neutral between government and opposition, and between different opposition parties. In contemporary, crisis-torn Zimbabwe, however, as was much the case in apartheid South Africa, this is increasingly difficult, for civil society has become deeply politicised. Indeed, Olaleye (2005: 32) suggests that the concentrated critique of ZANU (the ruling party) - which emerged in the early 1990s from academics, the labour movement, human rights groups, professional bodies and NGOs - did so in some measure as a result of 'prodding' by the donor community. Precisely because there were severe restrictions placed upon such groups, democracy assistance initiatives were vital in strengthening their capacity to challenge the government. 
To that extent, they contributed significantly to the launch of the opposition Movement for Democratic Change (MDC), the party - headed by former trade union leader Morgan Tsvangirai - that seriously damaged the legitimacy of ZANU at the 2000 parliamentary and successive elections. Yet such politicised aid has had the inevitable outcome that pro-democracy organisations and the MDC have been pilloried by the government as agents of Western subversion, which in turn leads to multiple difficulties.

Not least of these is the requirement, from September 2003, that all NGOs should register under the Private Voluntary Organisation Act of 1995. This enabled the government to police the spending of donor funds. Although no organisation has yet been banned under this Act, the present environment in which NGOs are operating can be described as a war zone, with numerous activists joining MDC supporters as victims of official harassment and violence. Indeed, the relationship between the government and both NGOs and many donors is now so hostile that a number of the latter have opted to disengage, either by withdrawing, reducing their support to NGOs or eliminating the democracy components from their aid packages altogether (Olaleye, 2005: 32-6). Official democracy assistance requires legal or officially tolerated political space in which to operate.

\section{Support for political parties}

Whereas in the 'struggle years', liberation movements such as South Africa's ANC were assisted directly by sympathetic governments and by supportive solidarity funding and activities, democracy assistance has subsequently sought to assume a neutrality between competing political parties, and help has been directed at enabling them to consolidate multiparty democracy. Such assistance has taken two principal forms.

First, responding to the new importance attached to the funding of parties if democracy is to be sustained, some governments have contributed to official funds - usually distributed by electoral commissions - that are allocated to parties to enable them to conduct their electoral campaigns. Although opposition parties regularly complain that the formulae adopted to determine the allocation of funds (which are usually constructed around parties' level of representation in parliament) work to reproduce the dominance of ruling and larger parties, they tend nonetheless to be highly dependent upon such support. Such funding has therefore sometimes served to 'buy' parties' agreement to participating in parliaments and formal political processes (Kabemba, 2003: 44). However, where donors feel that parties should be able to fund themselves (as in South Africa), or consider that there is insufficient transparency accompanying such official processes, or where they agree that allocation formulae are manifestly biased in favour of ruling parties (Zimbabwe), they have chosen to remain 


\section{Roger Southall}

on the sidelines. Overall, donors are wary of becoming embroiled in funding the expenditure of ruling and other parties that probing later reveals was provided covertly by the state or other governments or even business groups (such as the Taiwanese and Chinese in Lesotho) seeking political favours.

The dilemmas posed by direct funding of parties can in part be resolved by resort to the funding of local NGOs that assist parties with deploying polling agents, fielding female candidates, countering biases in official media, participating in conflict resolution and upgrading parties' capacity to perform effectively. Although welcomed by parties, there are regular expressions of dissatisfaction that such aid is donor-driven and, given the quality of service delivered by local NGOs, is ineffective (Karume, 2004b: 55). Parties on the whole prefer direct funding, but donors generally prefer the distance that indirect funding places between themselves and their recipients.

\section{Where to now?}

This chapter has shown that support to political parties is only one relatively limited aspect of democracy assistance strategies pursued in southern Africa since the early 1990s. While prior to that, donors tended to back horses according the political jockeys they were carrying, the shift to multipartyism and the liberation of South Africa have seen them wanting to act as neutral backers of new democracies. Yet this new situation has brought its own dilemmas.

First, multi-partyism, many of its procedures and even some of its values (notably the legality of opposition) are formally established but subject to the dominance of ruling parties that, in most countries, marginalises opposition parties and their capacity to hold governments to account. This is either because ruling parties continue to possess a popular majority, as expressed in elections, or because if they do not, they deny and obscure that fact, and refuse to give up power. SWAPO, the ANC and the Lesotho Congress for Democracy are all prime examples of the former, ZANU by far the most explicit example of the latter (but look out for the Botswana Democratic Party, whose 'liberal authoritarian' rule is draining substantial popular support yet seems increasingly to be backed by the military) (Good and Taylor, 2005). Such parties may still offer 'free' elections, but ones that may be 'unfair'. For the moment, 'democracy' implies the possibility of change of government only in those poorer countries (Malawi, Zambia) where the hold of ruling elites is or has been severely challenged by internal party revolts.

A related point is that in a region where in most countries the economy is impoverished, significantly dependent upon foreign aid and dominated by external capital, politics - or rather, control of the state - continues 
to provide the principal route for accumulation by elites. Currently this is most dramatically illustrated by Mugabe's Zimbabwe, where ZANU's grip on government continues to enrich key party loyalists, despite the downward spiral of the economy. Land seized from white farmers has been distributed to placemen, the armed intervention in the DRC in 1998 allowed senior military officers to appropriate and illegally export valuable natural resources, and access to power simultaneously provides access to scarce foreign exchange, which the politically favoured purchase at artificially low rates with a near worthless local currency. But corruption and misuse of resources is endemic to the region. In Namibia, former President Nujoma has aped Mugabe by building a vast luxury presidential palace. In both Namibia and Botswana, former heads of state have been provided with munificent retirement packages, which in the latter case probably amounts to a value in excess of 2 million pula (around 2.5 million rand) a month. In South Africa, the ANC is presently wracked by a crisis resulting from the jailing of 'crony capitalist' Shabir Shaik, whom the presiding judge described as having formed a 'generally corrupt relationship' with (then) Deputy-President Jacob Zuma. Alongside other simultaneously unravelling cases, 'corruption within the (formerly ruling) National Party is beginning to look like a tea party' (Kadalie, 2005: 16).

It is not surprising, then, that there is substantial disillusion with democracy as it exists. Bratton, Chikwana and Sithole (2005) report that support for democracy as the preferred form of government in Zimbabwe has slumped from 71 per cent in 1999 to 48 per cent in 2004 (and, worse, that fully 83 per cent indicate a high level of fear). They also record that support for democracy in sub-Saharan Africa more generally has slipped from 69 per cent to 64 per cent between those years. Such disillusion regularly takes the form of declining participation rates by voters at election time (even if, as in South Africa, where the 75.7 per cent turnout in 2004 was lower than the 86.7 per cent turnout in 1999 , voters continue to register greater enthusiasm than in most established democracies). Where democracy is viewed in large measure instrumentally, its failure to deliver in terms of jobs, education, health and other goods may well to lead to widespread distrust in politics, apathy, or support for non-democratic alternatives.

Nor is there significant prospect that economic growth will transform this situation. To be sure, there are some encouraging developments. The ANC government in South Africa is lauded for having achieved macroeconomic stability and for having facilitated consistent year-on-year growth since 1994, and for having delivered impressive benefits such as housing, water, sanitation, and social grants to the poor. It is also responding to the limits of its post-1996, market-led strategy by turning to more interventionist and expansionist policies, which indicate that it is preparing to take a lead role in priming the economy, and hence to compensate for 


\section{Roger Southall}

the reluctance of private capital to invest in job-creating ventures (Southall, 2005). Yet against this, the present rate of growth is insufficient to provide rising per capita incomes, and the government is unable to meet many of its development targets.

Certainly, compared with a decade ago, southern African economies are manifestly healthier. Apart from South Africa, countries such as Mozambique, Angola, Tanzania and even Lesotho are recording impressive growth rates, much of it fuelled by post-conflict infrastructural development (and it is hoped that the DRC is on the verge of similar progress). Increasingly, too, they are being opened up to foreign investment and to external communications (the growth and use of cell phones and even satellite television over the last decade has been phenomenal, even if Africa still lags far behind with regard to use of the internet). Yet for all the talk of Mbeki's commitment to promoting good governance regionally and continentally as an attraction to foreign investment, no government within the region, except for South Africa, has yet signed up to the African Peer Review Mechanism (the process attached to the New Economic Programme for African Development, designed to assess the quality their quality of governance, to which governments are invited to voluntarily subject themselves), and some, notably Zimbabwe, regard it with total contempt (Masterson, 2004). Growth and development prospects are also compromised not only by concurrent crises of mass poverty and some of the highest rates of HIV/AIDS in the world, but by a 'new scramble' for Africa's resources notably oil, energy, water and minerals - in which South Africa is engaged in spiralling competition with (especially) American and Chinese, but also European, capital (Daniel and Lutchman, 2005). Indeed, this suggests that the region is about to witness a new informal imperialism in which domestic elites become increasingly linked to external forces, and which confirms the lowly global status of local economies as externally dependent suppliers of raw materials to the advanced and rapidly industrialising parts of the world. There seems little prospect, in short, that sustained economic 'growth' will underpin democracy.

How does this alarming situation speak to the issue of democracy assistance to regional political parties in an age of rapidly advancing globalisation?

Certainly, it seems that after the excitements of the 'second wave' of democracy in southern Africa in the early 1990s donors are having increasing doubts about the effectiveness of their governance assistance packages: policies and activities with mainly constructive yet uncertain and largely immeasurable outcomes. Donors, notably the influential German foundations, therefore, are reported as re-assessing their options (see Chapter 10). During the early years the Stiftungen (notably the socialdemocratic Friedrich Ebert Stiftung) worked closely with African socialist parties and national liberation movements and sought, in essence, to 
fashion them into their own image as mass-based parties, only to find subsequently that they became authoritarian, non-participatory and often corrupt. Hence their shift, along with official aid agencies, to non-partisan support for political parties, and for rendering multi-partyism legitimate, free and fair, accountable, woman-friendly and participatory. But once again, if the analysis in this chapter is correct, they are facing a developing crisis of democracy. How should they now respond?

The immediate answer is: 'with caution and expecting considerable difficulty'. First, of all, it must be stressed that for all their shortcomings, the present packages of democracy assistance remain absolutely essential to the maintenance of democracy (such as it is) in all southern African countries. Within this context, direct and indirect aid to parties is vital, notably for keeping the spirit of opposition alive, ensuring that elections adhere to reasonably adequate standards, that parties facilitate popular participation, and that they contribute to the demand for accountability. Of course, precautions need to be taken to ensure that parties are genuinely representative of some segment of society and that they are not simply vehicles of private interest. Similarly, much present experience suggests that more attention should be given to building the internal capacity of parties between elections and assisting them to extend their structures beyond the urban centres and to communicate more regularly with their rural constituencies. Nonetheless, such common sense does not in itself address the core problems of the looming crisis.

These problems are presently most acute in Zimbabwe, where opposition parties, notably the MDC, are subject to a systematic narrowing of the legal and political space in which they operate. Legally, for instance, MDC leader Morgan Tsvangirai has had to face a succession of charges of treason that, while ultimately unsuccessfully pursued by the state, kept him tied down for months. Politically, the MDC is hamstrung, not merely by its strategic miscalculations (which in the second half of 2005 produced acute internal divisions around whether to participate in elections for a newly created Senate, to be conducted under conditions that were grossly skewed in favour of ZANU) but by the terror visited upon those deemed to be opposition supporters. Following the regime's deployment of food aid (in a now starving country) to bludgeon voters in election campaigns, it went on to engage in a 'pogrom' against the poor, in which the shanty dwellings of some 200,000 people in urban areas were destroyed in a 'clean up' that has seen their informal livelihoods as much as their impoverished homes destroyed.

In this appalling circumstance, it is inevitable that democracy assistance should have become politicised, that is, that it is directed at pro-democracy NGOs and political parties opposed to the incumbent regime. As noted above, this carries the costs that recipients of aid are accused of being tools of Western interests and subject to official violence. Yet there can 


\section{Roger Southall}

be no other way, and this surely points the way forward for any future strategy for assisting political parties in southern Africa.

There are likely to be two poles to such a strategy, ranging from formal neutrality to a partisan, pro-democracy stance. The neutral position is largely described by the mutually supportive democracy assistance activities, inclusive of direct and indirect aid to political parties, which have been analysed above. It may be characterised as seeking to contain the worst effects of the dominant party state by seeking to ensure freedom and fairness in elections, sustaining opposition, promoting accountability, encouraging political participation and so on. At its best, it should be directed as much at the ruling parties as at the opposition, for it needs constantly to be remembered that while entities such as SWAPO and the ANC seek to maintain their dominance of the political arena, often by means that are more foul than fair, they are themselves composite organisations whose culture combines liberatory traditions with the drift to authoritarianism. External assistance should therefore be directed at promoting intra- as much as inter-party democracy, designed to keep alive the ideals that guided such parties in the struggle for liberation. This is a necessary corrective to the elite domination of democracy of which Good (2002) is so critical. Attention, too, needs to be given to enabling social movements, such as those presently emerging in protest against 'delivery' failures in South Africa, to participate within political structures and to stretch their democratic potential, rather than resorting to a destructive populism which can so easily invite an authoritarian response.

The second, partisan pole of party assistance needs to learn from the struggle against apartheid, most notably in the 1980s. Such a strategy requires that those offering democracy assistance make difficult political choices (which in turn will imply that strategies adopted may have political costs). While there may be broad unanimity that an incumbent regime is unjust, oppressive, unpopular and must at some time be removed, it is very possible that different donors will back different horses (among political parties as among NGOs). This always carries the danger that external intervention can prove divisive (for instance, in South Africa conservative support for the Inkatha movement and minority black trade unions was often deliberately designed to weaken support for the ANC) and in the present era, Western governments are likely to be ambivalent about democracy promotion if that might endanger their strategic economic interests. Nonetheless, it is similarly likely in such circumstances that a leading pro-democracy movement or party will emerge and possibly assume the mantle of a regime in waiting.

In such circumstances, the lead in democracy assistance must surely be taken by broadly progressive forces. That means social democratic parties, sympathetic governments and their associated foundations and trade unions, as well as the more progressive churches. Their responsibility is 
to promote unity within the pro-democracy movement, assist it to become hegemonic internationally (far from easy in a situation where Mugabe can bang the anti-colonial drum to mobilise local support from African governments), and work closely with the movement's external organisations, supporters and allies. Just as a body such as International Defence and Aid directed covert aid inside South Africa to fund legal cases and to support victims of apartheid, so a major aspect of support for a prodemocracy movement must be the defence of human rights alongside humanitarian aid, often working in collaboration with exiled networks of refugees and party supporters. Importantly, too, the objective must be to enable the pro-democracy movement to survive, to endure inevitable setbacks, and to view its struggle as a long-term process - whose outcome may not be an outright victory, but rather a difficult transition in which it needs to be ready to make strategic compromises with the regime it is opposing, without conceding fundamental ground. Yet even if such a transition results in a 'second best' solution, democracy assistance should be directed not merely at resolving conflict and preventing the relapse of a Zimbabwe into a failed state, but also at installing protective institutions within a reformed polity that maximise rights and freedoms, and minimise the scope for corruption and unaccountability.

Party support, at this pole, demands participation in the construction of a solidarity network in which committed political activists link up with the democratic movement globally in offering moral, material and strategic assistance. In this, certainly, it would seem that the new global communications network of email and the internet will facilitate interaction, even though authoritarian regimes will seek to block it. Such solidarity networks will often be in advance of official democracy assistance, which is perpetually constrained by diplomatic caution, and in the Zimbabwean case, by a South African government reluctant to take firm action against a fellow regime with a 'liberation' background. Meanwhile, the terrain may well be complicated by the increased levels of official aid being provided by China to local regimes, none of which has as yet a specific democracy component and most of which appears designed to promote Chinese strategic interests. Worse, where the new Chinese engagement in Africa runs in direct competition with Western interests, it is likely that the latter's commitments to democratisation will come second to their scramble for scarce minerals and other resources.

At this pole, therefore, assistance for a popular movement must often be as much directed against complicit governments as against an offending regime itself. In other words, this suggests a distinction between 'official democracy assistance' (offered by governments) and 'solidarity assistance' (offered by bodies prepared to assume something of a more politically explicit 'vanguard' role), which, while they may be complementary, may also imply a greater willingness by the latter assistance to take a political risk. 


\section{Roger Southall}

Is this history repeating itself? And will a popular movement that achieves power with solidarity support subsequently reproduce itself as a dominant party? Perhaps, but at least in a globalising world it is less easy for repressive regimes to shield themselves from sight, and more easy for progressive forces to combat them with wider global support, and to engage in the struggle for democracy as an unending battle. 


\title{
10 Hesitant bedfellows
}

\author{
The German Stiftungen and \\ party aid in Africa
}

Gero Erdmann

\section{Introduction}

There is very little research about the German political foundations available in English (Pinto-Duschinsky, 1991; Mair, 2000a) - not to mention that it is equally sparse in German. Even though the foundations belong to the German political parties, their international activities are not well understood by either politicians or the general public. The foundations themselves have only recently started to make an effort to inform the public about their activities, which is partly due to the fact that their activities have been, and continue to be, a sensitive issue in German politics (Mair, 2000a: 128; 148).

Despite this widespread ignorance the fact remains that the foundations have been extensively involved in some very important political transitions: in Portugal, Spain, Chile, South Africa and Namibia. Some observers rank them among the major providers of political party aid (see Chapter 4); and among the European foundations that provide democracy assistance they possess by far the largest annual overall budgets (Van Wersch and de Zeeuw, 2005: 7).

With all due respect, however, the foundations should not be perceived as party promoters in the usual sense. The aim of this study is, first, to try to correct the main misunderstandings about the nature and purpose of the work of the German political foundations. Second, the chapter analyses the challenges that the foundations face in sub-Saharan Africa as well as describing the activities that are related to political parties in Africa. Finally, the chapter will attempt to assess whether the foundations actually address the African challenge adequately.

\section{German political foundations in context}

The German political foundations are usually identified with the 'partisan approach' (or 'fraternal' or 'sister' party work) meaning that they collaborate only with parties of kindred ideological direction: liberal, social democratic or Christian (Carothers, 1999: 141; Kumar, 2005: 507). This, 


\section{Gero Erdmann}

however, is only partly true. ${ }^{1}$ Actually, the very idea of a 'partisan approach' to party aid could cause legal problems for the foundations. The international support of political parties is a legally ill-defined area for the foundations. For instance, in Germany itself, where the political foundations operate in the civic education sector, German party law proscribes support to any political party. However, the legislation is unclear as to whether the law also applies to the operations of the foundations abroad. Instead, the international operations of the foundations appear to be controlled only by the accounting rules laid down by federal parliament and the Ministry of Economic Co-operation and Development (Bundesministerium für wirtschaftliche Zusammenarbeit und Entwicklung, BMZ). According to $\mathrm{BMZ}$ rules, foundations are not permitted to directly sponsor political parties and trade unions or electoral contests and labour disputes (BMZ, 2005). Furthermore, it is also stipulated that their activities should not harm German interests, which means that the Ministry of Foreign Affairs has to scrutinise all foundation projects and programmes, although it does not have the final say. In a sense the foundations are, on the one hand, an arm of German foreign policy - 'clandestine diplomats'. But on the other hand they are supposed to be 'autonomous', with the upshot that they sometimes operate in areas that the official policy wants to avoid.

This legal grey zone provides room for a spectrum of interpretation, which the various foundations make good use of. Some foundations interpret the rules quite liberally and therefore co-operate more closely with particular political parties, while others are more 'conservative' and keep their partners at arm's length.

The political foundations are not 'party foundations'. But their position has to be understood as 'close' to one of the political parties. After being represented in the German Federal Parliament (Deutscher Bundestag) for two consecutive elections each party is entitled to receive funds from the Ministry of Home Affairs and the Ministry of Education for civic education in Germany. For their international work they receive funds mainly from the BMZ and some from the Ministry for Foreign Affairs. Naturally, in their activities the foundations are subject to the legal restrictions of each country in which they operate.

There are currently six political foundations: the Friedrich Ebert Stiftung (FES, founded in 1925), which is close to the Social Democratic Party (SPD); the Konrad Adenauer Stiftung (KAS, founded in 1956) which is related to the Christian Democratic Union (CDU), the Heinrich Böll Stiftung (HBS, founded in 1996-97), ${ }^{2}$ which is linked to the Greens (Bündnis 90/Grüne); the Friedrich Naumann Stiftung (FNS, founded 1958), which is close to the liberal Free Democratic Party (FDP); the Hans Seidel Stiftung (HSS, founded in 1966), which is related to the Christian Social Union (CSU), the Bavarian sister party of the CDU; and the Rosa Luxemburg Stiftung (RLS), which is close to the Party of Democratic Socialism (PDS), the 
Table 10.1 Regional distribution of German political foundations' spending, 2001-05 (percentages)

\begin{tabular}{llllll}
\hline & $F E S^{a}$ & KAS & $H B S$ & $F^{2} S^{a}$ & $H^{b} S^{b}$ \\
\hline $\begin{array}{l}\text { Africa (south of } \\
\quad \text { Sahara) }\end{array}$ & 25 & 14 & 17 & 13 & 15 \\
$\quad$ Asia & 19 & 17 & 19 & 26 & 34 \\
Latin America & 20 & 24 & 19 & 12 & 12 \\
$\quad \begin{array}{l}\text { Middle and Near East/ } \\
\quad \text { Northern Africa }\end{array}$ & 12 & 9 & 14 & 13 & 17 \\
Others & & 36 & 31 & 36 & 22 \\
\hline
\end{tabular}

Source: Figures provided by the foundations (partly author's own calculations).

Notes: a 2001-04 only; b 2004 only; c includes spending in Southern, Eastern and Middle Europe, in Eurasia and in Brussels, although the distribution among these destinations differs from one foundation to another.

RLS did not provide any data.

successor to the former state party of the German Democratic Republic, which existed before the elections of 18 September 2005.

The overall amount available to each foundation is based on the size of the associated parliamentary party and their respective status as an official parliamentary group, although the amount that each foundation receives is not exactly proportional to the number of parliamentary seats that the associated party has. At present, the proportions are: FES, 35 per cent; KAS, 32 per cent; the remainder divided more or less equally among the smaller foundations. The RLS is also recipient of additional funds. ${ }^{3}$ The foundations do not receive a lump sum to dispose of at will, but rather have to apply to the BMZ for specific amounts for particular programmes and purposes. In all, over the last five years the BMZ provided on average $€ 162.4$ million (equivalent to around $£ 112$ million) per year to all the foundations (BMZ, 2005). Additional funds are received from the Ministry of Foreign Affairs and the European Union.

Each foundation, however, has its own regional distribution of funds. FES is by far the most active foundation in Africa followed by HBS and HSS together with KAS, and finally FNS (see Table 10.1). The amounts given here cover only BMZ financing and do not include financing for the foundation's activities in Germany. It is important to observe that these amounts are not to be equated with assistance to political parties, but comprise their total democracy assistance budget. ${ }^{4}$

\section{The African challenge}

\section{'Unknown' objects: political parties in Africa}

There is a general agreement among scholars as well as development and political professionals that supporting parties in young democracies is a 
particularly challenging task (Burnell, 2001:188-204). The reason is simple. Political parties in young democracies have certain features that distinguish them from parties in well-established democracies: (1) fewer members; (2) weaker organisations; (3) fewer distinct programmes; (4) weaker linkages with (civil) society; and (5) weaker party identification. Hence the electoral support will be very volatile (Mainwaring, 1998; Von Beyme, 2000; Schmitter, 2001: 67-89). From a functionalist perspective, this means that those parties will, most likely, fail to adequately perform the 'core functions' of political parties in a democracy: (1) provision of ideological orientation and political goals (symbols); (2) socialisation and mobilisation; (3) aggregation and articulation of interests; (4) elite recruiting and government formation; (5) organisation of loyal opposition (and formulation of political alternatives).

Moreover, the experience of political party promoters and the models upon which party aid is based is that of the industrialised countries. But the appropriateness of this experience needs to be examined. For a start, it is a very specific model of the 'mass-party' of Western Europe during the first half of the twentieth century, which is not even applicable to the United States. Carothers (in Chapter 4) calls this model 'mythicised' And even in Europe the 'golden age' of the mass party passed away some time ago and has been replaced by the 'catch-all party', the 'cartel party' or various 'electoralist parties' such as the post-materialist Green Party. These parties are quite substantially different from the mythical mass party (Katz and Mair, 1995; Gunther and Diamond, 2001).

As a caveat, it is not only political party promoters who are wrongfooted by the model of the mythical mass party but a great deal of political science, which is still very much dominated by the history and model of political parties in Western Europe. Although the discipline is waking up due to the development of political parties in the young democracies that do not match the familiar picture, we still lack an adequate alternative conceptual framework. In a sense, only our awareness of the problem has increased. Research on political parties in Africa is particularly affected (Erdmann, 2004).

Although systematic research is only now emerging, some basic features of political parties in Africa appear to be well known: (1) they have barely distinguishable programmes; (2) they have weak bureaucratic organisation, which in many cases is only temporarily in operation; (3) they are characterised by informal relations, partly based on clientelist relations and patronage that dominate the party structures; (4) the formal internal structures are dominated by strong personalism; (5) they have a high degree of factionalism; (6) they are characterised by a lack of internal democracy; (7) data for party membership are unavailable or unreliable, because there is either no formal membership or, very frequently, there are multi-memberships (card-holding of several parties) - thus 'membership' is weak apart from a small group of staunch party cadres; (8) they 
have predominantly regional and/or ethnic-based membership and voters; (9) the funding base is weak and is not based on contributions of a broad membership, but on the purposeful donations of rich individuals; (10) formal linkages to civil society are weak (Erdmann, 2004: 65).

There are, of course, exceptions to these features. In particular some of the former 'state parties' of the one-party regimes still have a comparatively stronger bureaucratic organisational form; and ruling parties often appear to be better organised than the opposition parties. However, here one must still be cautious because ruling parties may not only make use of state finances for their own benefit but may also make good use of government structures for their operations. But evidence suggests that these parties do not as a rule invest very much in the party organisation. The dormant and even derelict headquarters of ruling parties strongly suggests this - and it is particularly acute once a party loses power.

Cross-country comparisons of Botswana, Ghana, Malawi, Tanzania and Zambia based on the author's own researches including interviews with party functionaries give an even clearer picture of the state of political parties in Africa:

1 In general, parties are essentially electoral associations that become active only for elections; between elections they are mostly dormant.

2 Generally only the bigger parties have bureaucratic structures, and where such structures exist they are mostly confined to the headquarters in the capital and in a few major cities.

3 Only one or two of the major parties have offices at the district level, and these may not even be operational or linked to the party headquarters.

4 There appear to be no visible operational party structures below the district level (but that does not mean they do not exist).

5 In most cases, local party organisations depend on the national headquarters from which they do not usually obtain any support. In some instances local level organisations rely on irregular contributions of one or a few rich local party members.

6 Larger parties in general do not lack of funds; but those they have come from famous party 'well wishers' and are only partly used for the party. These private funds are never properly accounted for and mostly used by individuals to promote their own personal political (or business) career.

7 The parties do not provide any civic education about the democratic process; at most they only inform the electorate about the technicalities of voting.

8 Only the General Secretaries of the political parties in Ghana were able to place their parties in well-known ideological left-right schema on their own initiative; the middle-level functionary could hardly tell the difference between the parties. 
9 Clientelism, originally thought of as supplementing the weak bureaucratic organisation, plays a far less important role for party organisation at the district and grass-roots level; it is, however, important at the top level of the party hierarchy in keeping the elite together.

10 Finally, aggregate electoral data as well as individual data from an opinion survey suggests that - except for Botswana which is ethnically fairly homogenous - ethnicity or ethnic affiliations play a crucial role for party formation and electoral behaviour, although not in the usually envisaged way for a highly fragmented party system.

Categorising the African parties can be done with Gunther and Diamond's (2001) universal party typology (linked to the social basis/cleavage), which includes the category of the 'ethnicity based parties' (Erdmann 2002: 259-85; Erdmann, 2004: 70-3). For this type of party two sub-types can be distinguished: an 'ethnic party', which is based on one ethnic group only; and an 'ethnic congress party', based on an elite coalition of several ethnic groups. The latter form is the most frequent in Africa.

One of our major problems is that we have very little reliable knowledge about the dynamics of these types of parties and how they support the consolidation of democracy. Only Horowitz (1985) has discussed this issue to some degree. In order to highlight the problem from the perspective of the party promoters, in a handbook on democratic party-building produced by the Netherlands IMD - a prominent actor in international party support - ethnic congress parties are not even mentioned. Instead the perspective of this handbook is clearly that of traditional 'mass party' and its organisational and representational function (Institute for Multiparty Democracy, 2004: 11). But it fails to capture the specific mechanisms and dynamics of political parties linked to ethnicity.

As regards the role of African political parties in democratic consolidation, the academic literature does not offer a very positive account but at the same time is not overly pessimistic (Randall and Svåsand, 2002b; Van de Walle, 2003; Mozaffar, Scaritt and Galaich, 2003). Despite some diverging views, some of the authors seem to agree that contrary to the general perception of the dangers related to ethnicity in party politics, there is a culture of compromise within the multi-ethnic parties of Africa. Others caution against passing judgment prematurely, citing positive developments in Ghana, Senegal and Botswana (Randall and Svåsand, 2002b). Another problem in Africa is the prevalence of the dominant party and the (pre)dominant party systems (Bogaards, 2004: 173-97). Again, the literature is quite sceptical about this 'awkward embrace' of one party that tends to promote a return to authoritarian rule (Pempel, 1990; Rimanelli 1999). Overall, the case for 'intervention' for the strengthening of political parties seems to be justifiable. 


\section{The demand side}

The success of political party assistance is dependent, of course, upon demand. However, we have no detailed knowledge about the sincerity of the demand. It is quite possible that party assistance is accepted simply because it is offered. As one analyst observed, in many countries 'the prevailing domestic attitude towards party assistance was one of "benign neglect"' (Kumar, 2005: 517). However, the writer is unsure whether this statement adequately captures the situation in Africa. For in the course of his own research on political parties in five African countries, he was regularly confronted with complaints by party leaders that international donors support all sorts of NGOs but not political parties. These leaders also questioned the political legitimisation of NGOs, and they stressed that it was important that political parties were legitimised by the electorate and that their members were sitting in parliament and taking up responsible positions in government. In short, they desired equal treatment by the donor community.

A survey of 14 party leaders of 11 political parties in nine African countries revealed the following picture. ${ }^{5}$ Asked whether political parties should receive such support from foreign donors, only two said that parties should not receive support from abroad while all the others said 'yes'. The two who did not want foreign donors to support parties were Nigerian and Mauritian; another Nigerian from the same party, however, wanted outside support. It should be noted that most of the resident directors of the foundations report a 'high demand' for party assistance, although in different degrees; and most local observers confirm that the foundations operate to a large degree according to local demand (although there are some exceptions) (Hanf, Hofmeier and Mair, 1995: 76-7; Mair, 2000b: 50). A second question concerned the mode of assistance they would prefer: either 'partisan' or 'non-partisan'. Again, the results were quite clear. Out of the fourteen leaders, eight wanted only 'non-partisan' support, while only two preferred 'partisan' aid. Another two preferred a combination of both non-partisan and partisan aid at the same time - an option that was not offered in the questionnaire but was written in by the respondents. And asked about the kind of assistance they wanted, the responses were largely 'material': finance and equipment.

Although the survey is anything but 'representative', three points should be emphasised. First, the positive reactions from the questionnaire together with the complaints noted above and the general response to the supply of party assistance confirm that there may be a general demand for party assistance. Second, seven of the parties involved in the survey participated in government, while one was a former ruling party; six of the party leaders were the secretary generals of the parties. A reasonable assumption is that party assistance would be more controversial on the side of ruling parties, because they are usually in a privileged position in that 
they command government resources and are rather hostile to foreign interference, especially if it involves supporting their competitors. However, the evidence contradicts this, underscoring the fact that most of the parties, including the ruling ones, are in severe financial difficulties. Third, there is a clear preference for 'non-partisan' assistance, which, again, gives support to the previous point. Finally, the demand for assistance in 'money' and 'kind' seems to reflect a general problem of the political parties in Africa, namely a lack of, and disinterest in, ideological and programmatic commitment - something that poses a challenge to the donors as well.

\section{Activities of the political foundations in Africa: misguided perceptions}

\section{Historical experience as party supporters}

Carothers' (2002: 19) emphatic argument that because it is an essential element of democracy assistance 'much greater attention to political party development should be a major part of the response' made by the democracy promotion community has been taken up by the political foundations for quite some time now. Their engagement with political parties in Africa dates back to the 1970s. Although the foundations had already begun their work in the 1960s, it was only for 'nation building' and the export of the 'German model' of economic and social policy. It was only after Willy Brandt was elected president of the Socialist International (1976) that FES intensified its collaboration with political parties in Africa, especially with socialist orientated parties in Zambia, Tanzania and Senegal. In fact, FES made contact with the liberation movements in southern Africa in the early 1970s, backing the ANC in South Africa, FRELIMO, Namibia's SWAPO and the Zimbabwe African National Union and Zimbabwe African People's Union, which later combined forces in ZANUPF (Patriotic Front), 'with all means ... except for arms' - a move that was highly controversial inside FES, the Social Democratic Party and the Ministry of Foreign Affairs (Hillebrand and Vinai, 2002: 134-5). FES, for instance, financially supported an ANC and SWAPO office in Bonn with the official approval of the then Minister of Foreign Affairs.

These activities of FES do not mean that all the activities of all the German political foundations in Africa are directed at supporting political parties. First, none of the other foundations was very heavily involved in party aid in Africa, which differs from the situation in Latin America, for instance. With the exception of the FNS, the other two foundations at the time (KAS and HSS) co-operated with authoritarian state parties as well. Second, and this includes the FES, during the 1970s party collaboration was only one aspect of foundation work. Third, up to 1996, all the foundations had two budget lines, one for 'civic education' (gesellschaftspolitische Bildung) and one for the conventional 'socio-economic 
development' (Sozialstrukturhilfe). The budget for 'socio-economic development' accounted on average for about one third of the foundations' spending alone during the 1990s (BMZ, 2005). Before the changes of the 1990s, the major focus of activity was with conventional 'apolitical' and 'technical' social and economic development aid, rather than with party assistance. It included supporting civic and adult education, co-operative societies, or generally 'commonweal activities' (Gemeinwirtschaft), promoting business associations and supporting trade unions. In the 1980s, the promotion of the media and an attempt to foster intellectual capacitybuilding that would strengthen the role of the academia in engaging in political dialogue and political agenda setting became an additional focus of the work of the foundations, which, in many cases, was not very successful (Hillebrand and Vinai, 2002: 137). Fourth, during the 1980s even FES's interest in party assistance declined, because many of the parties were then perceived not to be democratic. More generally there was a perception (including inside FES) that FES's attempts to intensify the co-operation in membership training with African political parties bore virtually no fruit. The only exceptions were the co-operation with parties in two multi-party regimes, Botswana and Senegal, the Botswana Democratic Party (BDP) and the Parti Socialiste (PS).

The winds of change that swept Africa in the 1990s resulted in a reorientation of foundation work. The foundations now became part of the 'mainstream' promotion of democracy and human rights that focused on civil society organisations. By the mid-1990s, the BMZ budget line 'socioeconomic development aid' for foundation operations was completely scrapped, with funds being shifted to 'civic education'. This was, of course, due to the paradigmatic shift in development aid towards the creation of a favourable political framework, the promotion of human rights and democracy.

It is remarkable that in the mid-1990s political parties did not feature on the foundations' list of priorities (Mair, 2000a: 134). Instead, the foundations concentrated their work on non-governmental organisations, and, to different degrees, collaborated with state institutions such as the legislature and judiciary. Civic education was, however, a top priority. Nevertheless it is quite clear that the foundations supported political parties in Africa, although to different degrees. However, as of the mid-1990s, there has been increased awareness by the foundations of the importance of parties (Erdmann, 1996: 145-57; Mair, 2000b: 31, 64).

\section{New challenges - hesitant responses}

The six foundations currently operate in 29 countries with local offices in 22 of them. Only in South Africa do all the foundations have an office. Kenya has five offices, Tanzania four (of which the KAS office is run by 
Table 10.2 Project activities and offices of German foundations in African countries, 2005

\begin{tabular}{|c|c|c|c|c|c|c|}
\hline & FES & $K A S$ & $H B S$ & FNS & $H S S$ & $R L S$ \\
\hline Angola & $\mathrm{X}$ & $\mathrm{X}^{\mathrm{a}}$ & & & & \\
\hline Benin & $\mathrm{X}$ & $\mathrm{X}^{\mathrm{b}}$ & & & $\mathrm{X}^{\mathrm{b}}$ & \\
\hline Botswana & $\mathrm{X}$ & & & & & \\
\hline Burkina Faso & & $\mathrm{X}^{\mathrm{a}}$ & & & $X^{c}$ & \\
\hline Cameroon & X & & & & & \\
\hline Cap Verde & $X^{a}$ & & & & & \\
\hline Côte d'Ivoire & $X$ & & & & $X^{c}$ & \\
\hline DR Congo & & $\mathrm{X}$ & & & $\mathrm{X}$ & \\
\hline Ethiopia & $\mathrm{X}$ & & $X^{a}$ & & & \\
\hline Ghana & $\mathrm{X}$ & $\mathrm{X}$ & & $\mathrm{X}$ & $\mathrm{X}^{\mathrm{a}}$ & \\
\hline Kenya & $\mathrm{X}$ & $\mathrm{X}^{\mathrm{b}}$ & $\mathrm{X}^{\mathrm{b}}$ & $\mathrm{X}$ & $\mathrm{X}$ & \\
\hline Lesotho & & & $\mathrm{X}^{\mathrm{a}}$ & & & \\
\hline Madagascar & $X$ & & & & & \\
\hline Malawi & & $X^{a}$ & & & & \\
\hline Mali & $\mathrm{X}$ & $X^{a}$ & & & & \\
\hline Mauritius & $\mathrm{X}^{\mathrm{a}}$ & & $\mathrm{X}^{\mathrm{a}}$ & & & \\
\hline Mozambique & $\mathrm{X}$ & $\mathrm{X}^{\mathrm{b}}$ & & & & \\
\hline Namibia & $\mathrm{X}$ & $\mathrm{X}$ & $X^{a}$ & & $\mathrm{X}$ & $X^{a}$ \\
\hline Niger & & $X^{a}$ & & & & \\
\hline Nigeria & $\mathrm{X}$ & $\mathrm{X}$ & $\mathrm{X}$ & & & \\
\hline Senegal & $\mathrm{X}$ & $\mathrm{X}$ & & $X^{c}$ & & \\
\hline Somalia & & & $\mathrm{X}^{\mathrm{a}}$ & & & \\
\hline South Africa & $X$ & X & $\mathrm{X}^{\mathrm{b}}$ & $\mathrm{X}$ & $\mathrm{X}$ & $X^{b}$ \\
\hline Sudan ${ }^{\mathrm{d}}$ & $\mathrm{X}$ & $\mathrm{X}^{\mathrm{a}}$ & $\mathrm{X}^{\mathrm{a}}$ & & & \\
\hline Tanzania & $X$ & $\mathrm{X}$ & & $X^{c}$ & $\mathrm{X}$ & \\
\hline Togo & $\mathrm{X}^{\mathrm{a}}$ & & & & $X^{c}$ & \\
\hline Uganda & $\mathrm{X}$ & $\mathrm{X}$ & $\mathrm{X}^{\mathrm{a}}$ & & $\mathrm{X}^{\mathrm{a}}$ & \\
\hline Zambia & $\mathrm{X}$ & $\mathrm{X}^{\mathrm{a}}$ & & & & \\
\hline \multirow[t]{2}{*}{ Zimbabwe } & $\mathrm{X}$ & $\mathrm{X}$ & $\mathrm{X}^{\mathrm{a}}$ & $\mathrm{X}^{\mathrm{c}}$ & & \\
\hline & 23 & 19 & 11 & 6 & 11 & 2 \\
\hline
\end{tabular}

Source: Author's compilation following interviews with foundations.

Notes: a: no office; b: regional office; c: local staff only; d: at FES the Sudan office belongs to the Near East/North Africa Department.

local staff), and in five other countries only three foundations are resident with offices and a German representative (see Table 10.2). Interestingly, of the six foundations only three (FES, KAS and FNS) presently have programmes or projects that are designed for collaboration with political parties.

The HBS, close to the Greens, does not work directly or indirectly with any political party in Africa (although it collaborates with representatives of parties on other continents). As an organisation with a post-materialist value orientation it is difficult for them to find congenial political parties in developing countries more generally. The family of Green parties is 
very small, particularly in Africa. For this reason the HBS has continued to focus its assistance on civil society organisations but is closely watching party development.

The HSS, close to the Bavarian Christian Social Democrats, does not presently collaborate directly with any political party in Africa although it did so during the time of one-party regimes (for example in Togo). The foundation now concentrates its democracy promotion on civil society associations, among them trade unions, business associations and rural co-operative societies. The target group of these programmes and projects are 'local political multipliers', including priests, teachers and mayors, of whom some will be politicians elected to public office or party representatives; the latter are included by chance, not by purpose, as 'party agents' ${ }^{6}$

The youngest German political foundation, the RLS, which is close to Party of Democratic Socialism (successor of the communist party of the German Democratic Republic (GDR), operates only in Namibia and South Africa and works with civil society organisations (trade unions), but not with political parties. The foundation has started to consider collaboration with auxiliary organisations close to the South African Communist Party (SACP), and, in fact, they are already assisting in the establishing the Chris-Hani-Institute, which is to be the think tank and civic education centre for the Congress of the South African Trade Unions and SACP. ${ }^{7}$

As indicated above, assistance to political parties is only one aspect of the foundations' assignment. Of the three foundations that collaborate with political parties, none is in a position to indicate how much assistance is provided for this specific field of democracy promotion; no aggregate data on party collaboration is available at the German headquarters. It is, therefore, almost impossible to assess the efforts that the foundations are making or to compare foundations to other forms of democracy assistance. Related to this is the basic question of how 'party assistance' is defined. One can use a very narrow definition that includes only those activities or projects that are directly and exclusively linked (contractually) with one or more political parties; or one can use a wider definition that comprises the collaboration with the parties' affinity groups (Kollateralorganisationen: kindred civil society organisations/groups) or, more broadly still, all sorts of activities that benefit the party system as a whole. This could even include projects related to the electoral system. Regardless of the definition used, there will still be problems of demarcation because none of the foundations works with a clear concept (the FES, however, is working on a definition for reviewing its activities in Africa).

When pressed to give an estimate of the foundations' share of party assistance, the following figures were provided. The estimate for FES was 'between one quarter and one third' of their activities; this would include the support for parliamentary groups. For KAS it was 'less than 20 per cent' of the total work in support of political parties. And FNS indicated 


\section{2}

the largest proportion, of 'one third to 50 per cent' of their activities. Rather than definitive sums these are estimates of the amount of 'work' that each office puts into party assistance; and the figures relate to Africa as a whole.

According to the three foundations party assistance has a high priority, and increased after the mid-1990s. Nevertheless it is, at most, only 25 per cent - and probably closer to 20 per cent - of the democracy promotion budget of all the three foundations. Hence it is difficult to see even these foundations as predominantly 'agents of party aid'; only the FNS explicitly sees itself as a 'party promoter'.

There are several reasons for this neglect of party assistance during the early 1990s. One is the 'bad experience' of the collaboration with the state parties during the 1970s and 1980s, which affected not only the FES. Second, the post-1989 era was the era that has been called the 'resurrection of civil society', in both theoretical and practical terms. Promotion of democracy meant (almost exclusively) promotion of civil society organisations, and the foundations were no exception to that kind of thinking. It took quite a while for the international debate to rediscover the existence of political parties. Third, it is difficult for the foundations to find congenial or even convenient partners in Africa that share their political and ideological orientation. Fourth, the perception is that most of the newly emerging parties have little in common with the parties they know from home. This is, of course, an acknowledgement of the unknown 'otherness' of most of the parties in Africa, and it relates, for example, to the lack of internal democracy in many of them, which makes the collaboration dependent on a few, sometimes erratic, leaders. Successful collaboration at this stage cannot be established without the consent of the leadership, but that can cause problems of its own because these leaders might try to use the collaboration not so much for the benefit of their party but for the promotion of their own position within the party. Fifth, and closely related to the previous point, collaboration with political parties is regarded as 'risky'. This means it requires a high and long-term commitment to gain trust on which a beneficial collaboration can be developed. But this kind of engagement can run into severe problems if one partner changes its political orientation (although that could still be a positive contribution to building party politics and democracy). Moreover, a too close involvement might create problems on both sides. All this reflects the weakness of political parties in Africa, but at the same time it also indicates some weaknesses on the side of the foundations.

\section{Attempt at an assessment: versatility and conceptual weaknesses}

Given the particular features of political parties in Africa, the key questions are, first, whether these distinguishing features have been identified 
Table 10.3 Bilateral partners of German political foundations in Africa, 2005

\begin{tabular}{|c|c|c|}
\hline FES & $K A S$ & FNS \\
\hline $\begin{array}{l}\text { African National } \\
\text { Congress (ANC), } \\
\text { South Africa }\end{array}$ & $\begin{array}{l}\text { Democratic Party (DP), } \\
\text { Uganda }\end{array}$ & $\begin{array}{l}\text { Democratic Alliance } \\
\text { (DA), South Africa }\end{array}$ \\
\hline $\begin{array}{l}\text { South West Africa } \\
\text { People's Organisation } \\
\text { (SWAPO), Namibia }\end{array}$ & $\begin{array}{l}\text { Comité d'Action pour } \\
\text { le Renouveau (CAR), } \\
\text { Togo }\end{array}$ & $\begin{array}{l}\text { Parti Démocratique } \\
\text { Sénégalaise (PDS), } \\
\text { Senegal }\end{array}$ \\
\hline $\begin{array}{l}\text { Frente de Libertação de } \\
\text { Moçambique (FRELIMO), } \\
\text { Mozambique }\end{array}$ & $\begin{array}{l}\text { Parti National Ensemble } \\
\text { (PNE), Benin }\end{array}$ & $\begin{array}{l}\text { Civic United Front } \\
\text { (CUF), Tanzania }\end{array}$ \\
\hline $\begin{array}{l}\text { Movimento Popular de } \\
\text { Libertação de Angola } \\
\text { (MPLA), Angola }\end{array}$ & $\begin{array}{l}\text { Mouvement National } \\
\text { de la Societé de } \\
\text { Développement } \\
\text { (MNSD), Niger }\end{array}$ & MDC, Zimbabwe \\
\hline $\begin{array}{l}\text { Movement for } \\
\text { Democratic Change } \\
\text { (MDC), Zimbabwe }\end{array}$ & & $\begin{array}{l}\text { [New Patriotic Party } \\
(\mathrm{NPP}) \text {, Ghana (1992-99)] }\end{array}$ \\
\hline
\end{tabular}

Source: Author's interviews.

by the foundations as a special challenge, and second, what approaches would address these challenges adequately.

\section{High versatility}

The following approaches in party assistance have been identified, which are used here as a heuristic tool in the absence of a proper evaluation of the foundations' party assistance: (1) party-to-party or partisan; (2) multipartisan; (3) cross-party dialogue; (4) institutional focus; and (5) international party linkage approach (Burnell, 2004: 14-17). Additional information from interviews and the writer's own observations will be used to supplement earlier evaluations of the general work of the foundations and their support of parliaments in Africa in particular (Hanf, Hofmeier and Mair 1995; Mair 2000b). Before discussing the various approaches, it should be pointed out that the foundations do not officially provide financial support or assistance in kind such as computers, vehicles and the like.

The 'partisan approach' means working with sister or fraternal parties that share the same ideological orientation. This collaboration builds upon trust and mutual understanding and is designed for a long-term commitment. In one sense it is the most 'politicised' as well as the most controversial approach. Germany's foundations are most often seen as the well-established practitioners of this approach - a perception that is only partly true as it is only one component of their party assistance. In fact, the foundations currently collaborate on a bilateral basis, each with only 


\section{Gero Erdmann}

four to five political parties in Africa (Table 10.3). In the case of the FES these partners are, with one exception, still the 'traditional' ones, the parties of the former liberation movements that have become dominant parties. This poses a special challenge for party aid. Often the collaboration, apart from direct talks and advice, is conducted 'indirectly' through the assistance of a think tank or research institute that is close to a political party, or, quite frequently, through parties' affinity groups (Kollateralorganisationen).

Most of the party assistance provided by the foundations for Africa is clearly directed towards what is termed the 'multi-partisan approach' (multi-party or cross-party), which is the internationally most common and most favoured approach applied by organisations such as USAID and the Netherlands IMD. As can be seen from the list of bilateral collaboration in Table 10.3, the foundations collaborate with ruling as well as with opposition parties, although in most cases the assistance started when the parties were in opposition (particularly in the case of the former liberation movements). It does not make sense to stop collaboration as soon as an opposition party comes to power; the formerly weak party structures do not become strong overnight once an opposition becomes the ruling party. The promotion of internal party democracy is particularly important for ruling parties. However, in authoritarian or hybrid regimes the natural partners of assistance are usually opposition parties.

The multi-party approach of the foundations does not imply assistance to all parties. It means, instead, the identification of 'relevant' parties; anti-democratic parties are excluded. In a democratic setting 'relevant' parties usually include parties represented in parliament. To base the selection of recipient parties on this criterion is not opportunistic as long as the representation is based on free and fair elections; the support of parties is then 'objectively' related to the choice of the electorate. However, in a pre-transition situation when no founding elections have taken place, gauging the strength of the various parties is not so easy and has to be based on informed guesswork. The usual way the foundations operate in this situation is through workshops, training seminars, foreign visits focusing on particular issues (media, parliamentary work, identifying programmatic and ideological orientation, code of conduct, special political issues such as decentralisation) relevant to these parties.

'Cross-party dialogue' is the third approach and difficult to distinguish from the multi-party approach. Although this model is in its entirety associated with the IMD (Burnell, 2004: 17) it has been long used by the German foundations. It is not only applied in countries with a history of violent conflict but also in many transition processes and in conflictprone situations. It is a useful approach to avoid high-tension situations escalating into violent conflicts. The foundations frequently provide the forum (and perhaps the mediator) to help people talk to one another and 
create mutual trust between hostile party members. The idea is to make political tolerance and the democratic 'rules of the game' a practical experience. This is done partly by the foundations themselves as an aspect of their local activities or by a third 'party' supported by the foundation. In some respects, the approach is even part of their routine collaboration with parties and not confined to conflict situations. Even many years after an actual transition to democracy the foundations regularly invite representatives of the major parties to all sorts of workshops and conferences to discuss particular issues that are of current national political relevance.

Fourth, the 'institutional approach' refers to the larger context of the institutional setting that influences the party system, such as the electoral system or the relationship between the executive and the legislature, which is manned by party representatives. The collaboration with these contextual institutions is also part of the foundations' operations and projects. The foundations assist the electoral commission, the office of the speaker of parliament, support parliamentary parties or provide training seminars for members of parliamentary committees. The relationship between the electoral system and political parties or between parliament and political parties might not be considered as crucial for party assistance, but there is little doubt that the electoral system has a bearing on the party system. As Burnell (2004: 18) has pointed out, weak parliaments lead to weak parties, which again can be related to a specific feature of presidential systems.

Finally, there is international cross-party collaboration at the subregional, cross-regional and pan-continental levels, which provides the possibility of discussing common problems and sharing experiences of party development. Again, the foundations support these encounters and joint activities by organising international conferences attended by party leaders of various countries, or by assisting regional federations of parties, such as the Union des Partis Africains pour la Démocratie et le Développement (UPADD) - comprising 17 member parties from 17 countries - by KAS, or the network of liberal parties by FNS.

Taken together, the foundations are not confined to the 'partisan approach', but instead display a variety of approaches and a high degree of flexibility, two features that have been recommended as a condition for an effective party assistance (Burnell, 2004: 14, 20). The flexibility becomes possible because of an almost singular feature these foundations have when compared to other political party promoters: in most countries in which they operate they maintain a permanent local office run, in most cases, by a German resident representative of the foundation.

This reliance on resident representatives has its advantages and disadvantages, but the advantages clearly stand out. As project managers they enjoy a high degree of autonomy; they are responsible for drafting new projects and programmes in collaboration with the local partners; 


\section{Gero Erdmann}

and they report directly to headquarters. Hence the success of the foundations' operations is very much dependent on the quality of the local representative. The long-term commitment to the post - usually at least three years in one country - enables foundation representatives to acquire a deep knowledge of the political situation and the dynamics of the civil society and party system, and to assess the strengths and weaknesses of potential partners. Representatives not only act as project managers but also as political advisors to all kinds of local actors, who need not themselves be 'contracted' project partners. This situation permits the representatives to establish long-term relationships with a wide network of local political actors, which again deepens their knowledge of the local politics. This enhanced network also makes it possible to engage potential partners in a close dialogue about prospective future activities and programmes and adapt to new or shifting demands in a way non-resident donors cannot react.

A final aspect, usually not discussed in this context, is the special capacity of the foundations to link up civil society with political party assistance. The crucial role that civil society organisations can play in relation to political parties as a critical companion, a corrective force or in agendasetting needs further elaboration. The possibility of furthering this is quite obvious in relation to the FES assistance to trade unions for which they run special programmes. But this opportunity does not as yet seem to be consciously elaborated in the strategic policies of the foundations. Thus the representative of FNS was the only one to explicitly mention this point as part of the strategy. One of the weaknesses of African civil societies is quite often that they do not engage political parties systematically, but instead try to avoid them (apart from the ruling parties).

A few remarks on the partisan versus non-partisan approach are necessary here. The idealised conception of a partisan approach, based on a pluralistic supply side that offers the local parties the freedom of choice as provided by the German political foundations, ${ }^{8}$ is difficult to find in practice. As indicated above, there is only one country in Africa that hosts the whole ideological spectrum of the foundations; and only six out of 29 host all the three foundations that provide party assistance: conservative, liberal and social democratic (see Table 10.2). There are many political situations in which a partisan approach may be completely inappropriate, while in others it is the only feasible possibility. In a transition period it makes little sense to support a ruling party that has only reluctantly agreed to democratic elections and that controls all the campaign means that are at the state's disposal. The concern that a partisan approach 'blurs the distinction between assistance and manipulation' (Kumar, 2005: 520) might be justified in some cases, where there is only one donor and that donor insists on pressing its own political beliefs on its partners. However, this is not usually the case. Moreover, we should not underestimate the self-consciousness of the leadership of African political parties, 
at least of the major parties, and their ability to choose with whom they want to collaborate. This is not to deny the existence of opportunism among party leaders, especially among smaller parties that do not have a large following. At the same time, neutrality ignores the amount of partisan money that is poured into political parties from private coffers, from individuals, the famous 'well wishers', as well as national companies and international corporations. Compared to the latter, the assistance rendered by international aid organisations, especially by the German foundations, is, in financial terms, small - in many cases, negligible. Even so, Mair's (2004: 131-5) point cannot be so easily dismissed that in some situations a partisan approach helps to clarify the recipients' value and norm orientation, particularly in parts of Africa where most parties display no clear ideological and political profile. By comparison with other donor organisations the clear (partisan) ideological orientation of Germany's foundations is quite often explicitly lauded by African observers and partners; they are not perceived as 'ideological missionaries' (Hanf, Hofmeier and Mair, 1995: 76-7). It should be remembered, however, that in the writer's own small survey most of the party leaders preferred a nonpartisan approach.

\section{Conceptual weaknesses}

While the German foundations' assistance to political parties provides a high degree of versatility and flexibility, the foundations do exhibit a number of weaknesses, which can be summarised as follows:

1 None of the foundations has a policy or strategy paper that deals with party assistance in general.

2 None has such a policy or discussion paper that addresses the specific issues of political parties in Africa.

3 None has either a particular post or a department that is concerned with political parties; FES entertains a post that is responsible for collaboration with 'trade unions'.

4 None runs a specific budget line for assistance to political parties, either overall or for specific continents or countries.

5 None has something like a 'tool-kit', 'guidelines' or a 'handbook' that gives some practical ideas on how to tackle the specific question of party aid; in the 1980s, FES had a handbook for party organisation that is now considered out of date and is no longer in use.

6 None has systematically appraised their particular collaboration with, and assistance to, parties, either internally or by external experts (although there have been various internal and external evaluations of certain other programmes of their work or of their work in general, for example, on a countrywide basis). 
7 All acknowledge the lack of systematic knowledge about their work with political parties; FES, however, has recently taken up the cumbersome task of defining, stocktaking and systematising their party-related activities in Africa.

8 Even the 'bad experience' - the dark shadow of party collaboration with the state parties of the 1970s and 1980s - has not been appraised in any substantial way.

Viewed from this perspective, the foundations appear not to be in a position to address the particular challenges of party promotion adequately, either in general or in Africa specifically. The foundations are certainly not distinguished in party promotion. This, however, does not imply that the assistance to political parties is ineffective or useless. There is a long practical experience with party assistance, but it is very personal and has yet to become institutionalised.

At the same time, the local representatives cannot be regarded as 'party experts', although some might have knowledge about the practical work of political parties from their private experience of being a party member back home. Generally they are employed as 'political technocrats'; they do not necessarily have backgrounds in party work or as active members of the related party. A few join the 'mother party' only after joining the foundation.

Nevertheless, given this context, the lack of policy guidelines and strategic planning combined with the autonomy and flexibility of the local representative means there is a danger that some of the foundations' advantages could turn into disadvantages, by courting arbitrariness, opportunism or simple lack of relevance.

\section{Conclusion}

The German political foundations are often portrayed as the genuine 'partisan' promoters of political parties. This is only partly true. While African political parties have increasingly enjoyed the attention of the foundations, only three of the six foundations - the social-democratic FES, the Christian democratic KAS and the liberal FNS - are engaged in political party assistance, and at most perhaps just 20 per cent of their efforts are devoted to this field of international democracy promotion.

Moreover, their party assistance is by no means confined to the 'partisan approach' as perceived by international observers. In fact, the foundations have only a small number of 'partisan partners' among African parties. Instead, they display a high variety of approaches. This, together with their special feature of working through resident representatives and their ability to combine political party with civil society assistance, gives the foundations a versatility that, compared to many other donors, is unique and can be seen as the most appropriate approach to political party aid 
in Africa. At the same time, discussions about the partisanship or nonpartisanship of party assistance seem to be misguided if they are only based on principle and ignore the context. At least the foundations are not perceived as 'ideological missionaries'.

Overall the reluctance to get too close to political parties is one reaction, among others, to the particular 'otherness' - commonly called 'weakness' - of political parties and party systems in Africa. A characteristic feature of this 'otherness' is the lack of clear-cut ideological and political orientation of the 'partisan work' of the foundations. Although this reluctance is understandable, it reveals a crucial weakness of the foundations: none has a strategic concept or policy outline to address the particular challenge to party assistance in Africa. Even the practical experience acquired in collaboration with these parties has not been translated into systematic institutional knowledge. This fact is crucial because it greatly affects the capability of the foundations to function effectively; and a lack of a clear policy makes evaluation of performance extremely difficult.

This summary of shortcomings taken with the indications given earlier in the chapter provide a rough outline of the issues and tasks ahead that need to be addressed in order to make party assistance more meaningful. It seems clear that we need to avoid a 'one size fits all' strategy. However, the necessity for highly specific approaches does not mean that we have to eschew general strategic considerations about how to focus party assistance in general. In sum, the problems that the foundations have with political party assistance in Africa are not specific to each and every foundation, but affect all promoters of political parties.

\section{Notes}

1 For a general overview of the foundations' mandate and role in foreign policy see Mair, 2000a.

2 The HBS is the successor of Stiftungsverband Regenbogen, founded in 1988, a federation of three smaller foundations close to the Green Party.

3 After being in two successive parliaments since 1990, following the elections of 2002 the PDS had only two MPs and therefore lost the official status of a parliamentary group.

4 See also: www.fes.de; www.kas.de; www.boell.de; www.fnst.de; www.hss.de; www.rosalux.de.

5 The survey, using a confidential questionnaire, was conducted by the author at an international political party conference in Accra, Ghana, sponsored and organised by the Friedrich Ebert Foundation in collaboration with the Institute of African Affairs, Hamburg, Germany. The party leaders involved came from Côte d'Ivoire, Ghana, Kenya, Madagascar, Malawi, Mauritius, Namibia, Nigeria and Tanzania.

6 Klaus Liepert, Head of Africa Department, HSS, telephone interview, 6 June 2005.

7 Jörg Schulz, Deputy Head International Relations, RLS, telephone interview, 18 May 2005; www.rosaluz.de.

8 This point is made generally in favour of the 'German approach' of the Stiftungen - see, for example, Mair, 2000a: 141. 


\title{
11 Looking to the future \\ Practice and research in party support
}

\author{
Peter Burnell
}

A number of the conclusions that follow from the preceding chapters may seem unremarkable: some of them reinforce existing knowledge. Many interesting questions remain. Notwithstanding globalisation, the universe of democracies is not approaching uniformity; there is no universalism in the sphere of party politics. The party systems remain diverse; some are far less competitive than others, and in many cases the situation may be too unpredictable to call. Moreover as research carried out by Gunther and Diamond (2001) into political parties suggests, there is no convergence on a single model of political party. In fact they indicated that a typology of five broad types - elite, mass, ethnicity-based, electoralist and movement parties - and 15 different species is needed to capture the diversity of party types around the world. Yet party politics has evolved and continues to evolve in different ways in different countries. Öniş's caution against extrapolating from the success of Turkey's Justice and Development Party in crafting a coalition of Islamic and secular forces cutting across different socio-economic groups to the Arab countries in the Middle East bears repetition. Indeed Turkey's own ability to sustain this particular party, let alone the party model it represents, far into the future is uncertain, especially if the country's prospects of gaining EU membership were to recede and reverberations from that played out in domestic politics. Meanwhile in Africa the persistence of clientelistic state-society relations whereby parties mobilise political support even while proposing to implement globally sourced neo-liberal economic solutions, warns us against taking too seriously some of the more exaggerated claims made on behalf of narrowly economistic notions of globalisation and its political repercussions.

On the side of party assistance, the conclusions are definitely mixed. The case studies appear to confirm that among the many international influences that might have a bearing on party politics inside emerging democracies, party support has been a relatively very minor factor to date. The fact that much aid has concentrated on the parties themselves to the neglect of the domestic forces and factors that influence party politics is only part of the weakness. Whatever the benefits such aid might deliver 
- and the evidence collected by Carothers shows these have been modest but not negligible - the effects can so easily be outweighed by other and more critical features of both the regional and the global environment. ${ }^{1}$ That can mean deliberate interventions in a country's politics that turn out to be misguided attempts to promote political change or, conversely, structural forces, institutions and trends that are wholly unconnected with democracy promotion but nevertheless affect the society, economy or government and thereby impact on the party politics. The Balkans offer some good examples where Gallagher depicts the adverse effects on democracy generally and party politics specifically of a number of external factors other than economic integration, and to which the societies' economic marginality in the world makes them more vulnerable. Giving a higher priority to international co-operation for addressing the imperatives of state (re)construction might be justifiable, but only if it is done well: if done badly, that, too, can damage the chances of healthy party politics taking root. Elsewhere in East-Central Europe, from now on the general economic and social effects that EU membership exert on the recent accession states can be expected to supersede whatever influence direct assistance to the parties had in the recent past.

\section{Party support}

The organisations that provide democracy support might reasonably wonder whether they do not have enough to grapple with already, without worrying about the potential significance of every aspect of globalisation, especially if the countries they are involved in are currently among the least globalised in economic terms. After all, purely domestic pressures can be expected to dominate the politicians' horizons there, both during the drama of democratic transition and later on when urgent constituencylevel demands arising out of poverty gain political voice, or if conflict between different sub-national communities still threatens peace and stability. However, the question can only be rhetorical where the commitment is to help build parties and party systems that can serve democratic purposes facing the strong probability that globalisation will continue to advance, extending its reach to more societies and to fresh domains of human activity. That understanding is essential if the party elites are to relate effectively to globalisation as subject as well as object.

The established literature on party politics gives some credence to the idea of path dependence: the kind of party and party system that emerges in a new democracy will be influenced by the preceding situation and by how the democratic transformation came about. Similarly, international approaches to supporting party politics for democratisation should consider the implications of globalisation, in order to avoid building in limitations now, or missing opportunities now, or overburdening parties with unrealistic expectations that will compromise the longer-term goal. 


\section{Peter Burnell}

For once they have been formed, party politics - like political institutions - can become 'sticky' or resistant to change. At the same time, globalisation and our understanding of globalisation, too, will exhibit a dynamic whose likely effects can barely be guessed. Southall's hint that China's growing integration into the global economy - which means that increasing trade and investment links with Africa could weaken the ability of Western actors to influence party politics or other political trends on that continent - is illustrative.

But in a 'shrinking world' where 'the sites of power and the subjects of power quite literally may be continents apart' (McGrew, 2005: 23), can democracy support help to build a justifiable confidence by society in party politics' capability to serve democratic purposes? The task does look daunting - perhaps even more so than the challenge of reversing the erosion of trust in parties and the integrity of the politicians that we read so much about in societies in the West. Perhaps democracy assistance practitioners should accept the notion that parties in many of the emerging democracies are unlikely ever to be the force they reputedly once were in the established democracies. If we recalibrate our assessment of what parties can do for democratisation then no one need be either perplexed or disappointed if international party assistance strengthens political parties only very marginally.

A more practical response in some cases would take the form of helping parties organise at the level of transboundary and supraterritorial governance and penetrate the decision-making processes that operate there. Here, the EU offers exceptional possibilities: independent support to parties in the new accession and prospective member states can help them negotiate the terms of closer inter-party engagement - managing their exposure to 'Europeanisation' - in ways that ensure the new relationships with Western Europe and its parties and the EU institutions themselves reflect their own and their own society's distinctive needs. A possible inference from Ágh's account of East-Central Europe is that the linked goals of learning how to represent their society's interests in Brussels and avoiding the negative consequences that accession can imply for party politics at home offer mutually reinforcing opportunities for the transnational pooling of advice. An inference from Gallagher's claim that the engagement of Western European parties with prospective partners among parties in the Balkans leaves much to be desired is that other democracy assistance actors must take a lead.

The EU is unique. Is some dedicated framework of governance such as a regional parliament endowed with formal powers not essential if party networking on a transnational basis is to have some substance? If not even the EU can claim to see the emergence of genuinely transnational parties, then what hope is there for meaningful collaboration between parties in regional and continental forums such as those Mohamed Salih 
describes in Africa? The idea of a sort of collective African peer review by political parties, both offering mutual support in learning how to cope with the pressures of globalisation and also holding one another's commitment to democratic values to account, is a brave one. But if contacts at that level are to move beyond the superficial, must there not be a shared sense of political community, at minimum what globalisation theorists such as Scholte refer to as the growth of 'communities of fate'? Are the activities that the existing party internationals already cater for not as good as it gets?

As major sites of important decision-making seem to be becoming increasingly remote from society's grass roots, and as lines of communication lengthen, so new strategies to (re)connect party elites with the people are badly needed. The moral here is that endeavours that prompt parties to look upwards and outwards should not mean neglect of renewed efforts to encourage parties to look inwards and downwards, too. That encompasses a wide range of issues, from those relating to gender equality to structures for intra-party participation and voter outreach. For the danger well flagged up by party analysts such as Katz and Mair (2002) and Poguntke and Webb (2005) - observing the established post-industrial democracies - is that the 'internationalisation of politics' and a greater orientation by party elites towards the institutions of supra-territorial governance could simply strengthen existing tendencies (seen in South Africa's ruling African National Congress, for instance) for power within parties (especially parties in government) to become increasingly concentrated at the top. The party elites, including leaders of opposition parties with governing potential, simply become yet more autonomous from party control as well as from societal influence more broadly (Raunia, 2002, sees this happening already within the EU context; Poguntke and Webb, 2005 , detect evidence throughout many OECD countries). Democracy support that encourages political parties in emerging democracies to 'look global' should be mindful, then, of the possibilities of producing or accentuating this unfortunate effect. And yet the two orientations - upwards and downwards - are, or should be, intimately connected. A party's ability to demonstrate genuinely strong popular support is a power resource that, together with specialised knowledge and technocratic expertise, can strengthen its capability to exert influence in or on the institutions of polycentric governance. Ways of making the upwards/outwards and inwards/ downwards orientations mutually reinforcing for the benefit of democratisation demand creative thinking and innovative practice. The challenge of developing parties as functioning multilevel organisations in their own right should not be underestimated: so far, much party aid (from the US, anyway) appears to have concentrated technical assistance on party headquarters and found it difficult to engage with the lower levels (Kumar, 2005: 513). Thus Carothers' recommendation that international 


\section{Peter Burnell}

party aid should do more to encourage a form of co-operation between parties and civil society organisations that goes beyond the largely eliteoriented participants in the policy communities, and instead reaches out to more broadly based and participatory movements in society, is highly significant.

Greater encouragement to civil society to do more to anchor parties firmly in society offers a large, relevant canvas for international democracy assistance. In at least some of the emerging democracies, the civil and the political seem to be not only separate worlds but rivals for resources and attention. Democracy promoters can single out for support those NGOs and INGOs whose purpose or mission inherently promises some clear benefit to the development of democratically organised party politics. Some obvious examples are transnational networking among elections observation and monitoring organisations and support for pressure groups and journalists committed to raising politically impartial standards in the media. Of course, the usual caveats must apply: any programmes of support 'should seriously study local conditions before deciding assistance approaches' (Kumar, 2005: 515). And indigenous capacity-building should be privileged, to discourage continued reliance on external help and guidance. There are countries where progress will be made only by working with the government to ensure that both NGOs and opposition parties are allowed the necessary freedoms and political space. Democracy support foundations may even have to choose between providing assistance to a party in power that is using its position to erode civil liberties and helping its partners in the civic sphere. Zimbabwe is an example. But helping to build the capabilities of NGOs to do policy research and offer policy advice, especially where the policy field is neither simply domestic nor foreign but cuts across or overarches both, need not be a zero sum game for the political parties. On the contrary, it offers a lifeline to opposition parties where the government (and thereby the ruling party) monopolises much of the country's own policy research expertise. In terms of whether economic globalisation's effects include narrowing the policy space in which political parties in emerging democracies can realistically offer the electorate meaningful programmatic alternatives, a 'partisan' approach to party aid by political foundations and parties in established democracies offers more of a counter than do the alternatives, although even its potential will be limited if these alleged effects of globalisation really are universal. Finally, of course, democracy assistance practitioners could factor a willingness to become more globally aware into the selection criteria they use when deciding which parties to favour with assistance and which parties to leave out.

Because the importance of the intermixing of politics and money is recognised by all analysts whether their interest is in party politics, in democracy more broadly, in democracy assistance or in globalisation, there is much still to be done in respect of how to resource parties and party 
politics in emerging democracies. The difficulty lies in devising arrangements that give parties the necessary degree of independence from their sponsor while consolidating a basis in society. If the argument that globalisation spells growing corporate dominance of politics is correct, then the conundrum is even more taxing in countries such as Russia or several African countries where substantial and increasing revenues flow to the state from the export of oil or some other valuable commodity. This can all too easily have a distorting effect on political funding, whether by rendering all parties dependent on the state or through partisan allocations that give advantage to the ruling party. It can make ruling parties even more determined not to lose office even if the electorate turns against them, that is to say, it can make ruling parties less committed to play the electoral process by the democratic rules of the game. A suspicion that parties are subordinated to special or sinister interests through the funding chain, or perceptions that parties purchase power through bribing the voters, are equally bad for democracy. No less pernicious is the practice observed in some new democracies for the victorious parties in elections to turn to recouping their campaign expenses through the corrupt use of public office. Thus the joint exploration by democracy assistance actors and political parties of alternative models of funding party politics seems well justified, as are collaborative measures taken at the inter- and supragovernmental levels to check the laundering of illicit or criminal money from international sources through political channels. Complementing International IDEA's knowledge bank on party funding regulation, for instance, the World Bank Institute's new 'transparency reform scorecard' contains several interesting proposals for the public disclosure of politicians' assets, incomes and contributions to political campaign expenditures.

\section{Pursuing the research agenda}

Political party aid remains a subject where advances in our understanding and advice on future action could benefit from greater collaborative research among the practitioners, academics and independent analysts in think tanks and policy research institutes. Indeed, Erdmann in Chapter 10 expressly recommends close collaboration 'because many of the problems encountered in party aid are in part the issues raised in party research'. Academia looks to practitioners to provide primary information about their experience and for their insights into the difficulties they encounter. In turn, academics have more freedom to investigate the larger systemic issues, studying the interactions among the many different variables that influence the development of party politics and conducting comparative analysis of the role parties and party systems play in democratisation. The acknowledgment by a senior practitioner of democracy aid that 'our support for parties outruns our theory' underlines the case for more academic research or better communication with practitioners, or both. ${ }^{2}$ 
According to Carothers (1997: 122-8), for instance, it is academics who can lead practitioners to pay more attention to the 'missing link of power' that strategies for democracy assistance strategies have so often neglected in the past. Given their local knowledge, political analysts inside the countries in receipt of democracy aid must also be part of the loop. Research collaboration, then, should both cut across the professions and take place on a transnational basis. This is important, not least if the existing tendency for global asymmetries in knowledge production and dissemination to harden into asymmetries of influence and power is to be countered.

Apart from being neglected as a subject for research, political party aid appears to have differed very little from the more general separation of democracy assistance and academic inquiry that Carothers (1997: 117-18; 2004a: 263-4) has written about in the United States and that probably applies to Europe, too. He makes sense of this state of affairs by saying that academia tends to look back, searches for explanations and almost invariably fails to reach agreement, whereas in contrast practitioners are more focused on discovering how to shape the future. This should give pause for thought: more research collaboration might be beneficial, but how much and what kinds, and could there be some disadvantages?

Assistance practitioners might view much of the very substantial academic literature on political parties as being of little relevance, confined as it is to more established democracies. Many of the most recent contributions are absorbed in the issue of whether parties are in decline, which hardly speaks to a professional interest in strengthening or building parties in the newer democracies. Also, academic analysts may worry about being harnessed to practitioner agendas - ones to which they do not necessarily subscribe. This is not necessarily a comment about the politically motivated drivers of democracy aid or democracy promotion in the larger sense, or a reference to the particular country/regional priorities that different democracy assistance organisations choose to specialise in, although these considerations certainly can be an issue. Instead, it means that practitioners are interested in what they can influence and how to do it. Nowadays most publicly funded organisations are mindful of the imperative to show results, and the sooner the better. Democracy aid organisations that either directly or indirectly receive their funding from official sources are no exception. Even the most autonomous of them should be committed to a culture of rigorous self-evaluation. The accurate recording of outputs and attempts to assess the effects must seem more pressing requirements than any amount of abstract theorising about party politics and democratisation in the longer run. Moreover the burden of accountability (being held to account) inclines most aid bureaucracies to be risk-averse; again, democracy assistance agencies are no exception. They each have their reputations to guard and their own 'take' on 'best practice' to defend. Evidence of friction among different sponsors or suppliers of assistance from the same country to political parties and civil society organisations in a country is not hard to find 
(River Path Associates, 2005). The competing arguments about the merits of bipartisan, multipartisan, and cross-party patterns of co-operation with parties mentioned by both Carothers and Erdmann also illustrate the point nicely. But highly political issues are bound to arise out of party support whether given in the context of election campaigning, strengthening the accountability of governments or in 'post-conflict' situations where relations among different communities, their political representatives and (para-)military groups may be extremely delicate. In such situations one can easily anticipate how a more open, focused and shared commitment by practitioners and others to exploring what party aid really means for changing the distribution of power inside a country could become just 'too political'. Willingness to share insights and information could then be compromised.

It is also true that the more normative aspects of democracy promotion and/or the particular institutional models that new democracies are being encouraged to adopt are questioned by at least some parts of academia, including some academics in the democratising countries themselves. This kind of critical interest in democratisation, or in democracy assistance more specifically, might well outlast the political appeal that the idea of supporting democracy promotion or specific ideas about how to do it currently enjoy among political leaders in the West. For some analysts of party politics (or, for that matter, of democracy promotion) there could be a genuine concern that too close an association with one or other democracy assistance organisation might make their own independent data-gathering more difficult - and not only in societies where critics see the globalisation of party-based democracy as just another form of imperialism, or where the political elites react badly to any suggestion that they might benefit from political party training. The issue of whether the democracy assistance agencies are at all accountable to the partners they work with in the prospective and new democracies is difficult to avoid here, although of course somewhat comparable concerns do apply to any unethical 'mining' and appropriation exclusively for the export of local research material by foreign academics as well. The African countries that are deemed to be candidates for Southall's proposal of partisan 'solidarity support' to pro-democracy actors offer an outstanding example of where some of these delicate issues regarding collaboration between academic researchers and some democracy support agencies might come to the surface. Care might have to be exercised over how much distance they visibly maintain from one another.

Political science can be expected to want to place the implications that party support has for parties, and even for democratisation, in a wider perspective than meets the proximate concerns of the democracy assistance industry. This is a reference to such issues as national political integration, political stability and social justice, which are no less compelling subjects than democratic change even though the interconnections 


\section{Peter Burnell}

are undeniable. Differences between parts of the academic and democracy promotion communities are magnified where the reasons why support to parties or national legislatures is seen to be so important rest largely on their potential usefulness for implementing agendas such as better economic governance and responsible fiscal behaviour, originating in powerful global governance institutions that lie well outside any democratic control. By the same token, political scientists and analysts of political parties specifically are interested in cases of non-assistance and in what can be learned from party politics in societies that do not receive democracy support. In sum, collaborative research should proceed on the understanding that academics will continue to be interested in the larger set of influences on parties, which should include globalisation. They will also study the implications that stable party politics mean for many other things - which should extend to globalisation - anywhere and without being committed to a particular way of providing party aid in emerging democracies, or even subscribing to the ethos of 'actually existing' democracy support.

\section{Conclusion}

In a globalising age there are at least three possible arenas for promoting party-based democracy: first, work with the parties and the immediate influences on them at the level of and below the nation and state; second, fashion and install new designs of transnational democracy such as the ideas for cosmopolitan democracy that are bruited in some of the literature, either to infuse greater legitimacy and accountability into the consolidating structures of polycentric governance or by substituting some more radical institutional solution; ${ }^{3}$ third, manage the forces of globalisation in some other way. No one type of international actor, including the organisations that provide democracy support, can be held responsible for taking action in all three arenas. But on present evidence the democracy practitioners are still toiling in the foothills of the first. And no powerful entity has even begun to think about developing approaches to the third, or even started to put the second into place, leaving aside the interrupted progress of EU attempts to deal with its internal democratic deficit (even within the European Parliament, the transnational party groupings appear to count for little relative to national party politics in determining how most parliamentarians actually vote on important issues, other than in roll call votes which account for around one-third of them). Indeed, even the political scientists who are most concerned about the armies of 'disillusioned democrats' they claim to see in today's post-industrial democracies have yet to come up with convincing designs for a direct democracy that could replace party-based models of political representation that are claimed to be in crisis or approaching terminal decline. As even the highly critical Power to the People (Power Commission, 2006: 187) concluded, 'we do not believe that the era of the party per se is over'. The double 
challenge of working out how to both democratise the institutions of regional and global governance and empower them vis-à-vis other supranational and transterritorial forces that increasingly influence people's lives - ranging from transnational corporations and media groups to the fears generated by international terrorism - is something for everyone to ponder. Failure to make real progress only places a greater responsibility on the shoulders of democracy assistance and its efforts to help party politics earn society's confidence in the ability of political parties to make a meaningful difference in the emerging democracies. If party aid practitioners want to know what practical things they can suggest to help parties in emerging democracies come to terms with globalisation - in the interests of both democratising globalisation and making democracy in a globalising world more worthwhile at the country-state-nation level, then for a start they need look no further. Scholte (in Chapter 3), in particular, offers a useful checklist of concrete areas where country-based parties could be doing more, or doing better, before going on to identify additional steps at the transterritorial level. Even if these early thoughts on the subject need more detailed elaboration, they most definitely should not be the last; at the same time they do lay down markers. When the time comes to evaluate the impact and effectiveness of democracy assistance more rigorously the methodology for doing so should be grounded in an up-to-date appraisal of what parties can and cannot do for democratisation in the presence of the challenges, constraints and opportunities posed by globalisation.

\section{Notes}

1 Credible scientifically-grounded assessment of the effectiveness and impact of democracy assistance of all kinds is scarce, and in respect of party aid in particular, assessments have hitherto been virtually non-existent. For what it is worth, a recent path-breaking quantitative study of expenditure on 'democratic governance' by the United States Agency for International Development in 195 countries over the period 1990-2003 found a statistically significant positive effect on democratisation both in total and in respect of the spending category 'elections and political processes' (party aid was not disaggregated from this or from the expenditure category for civil society, where the evidence was similarly positive) (Finkel et. al., 2005).

2 Comment made at a multinational workshop of democracy aid practitioners and academics on how to evaluate democracy assistance, held in The Hague, Holland, March 2005.

3 McGrew (2002: 216-25) surveys the alternatives offered by liberal internationalism, radical democratic pluralism, cosmopolitan democracy and deliberative democracy. He advises that although the first seems to offer the most feasible response, he is doubtful that it could deliver a substantively democratic global polity. 


\section{References}

Ágh, A. (2005a) Institutional Design and Regional Capacity-Building in the PostAccession Period, Budapest: Hungarian Centre for Democracy Studies.

Ágh, A. (2005b) 'Social Democratic parties in East-Central Europe: the party and civil society relationship', in P. Delwit (ed.) Social Democracy in Europe, Brussels: Université Libre de Bruxelles.

Ágh, A. (2006) 'The Europeanization of the ECE Social Democracy: the case of HSP in an ECE context', in E. Kulahci (ed.) Top-Down Europeanisation and Political Parties, Lanham MD: Rowman \& Littlefield.

Angell, A. (1996) 'International support for Chilean opposition 1973-89', in L. Whitehead (ed.) International Dimensions of Democratization, Oxford: Oxford University Press.

Aryeetey, E., Harrigan, J. and Nissanke, M. (eds) (2000) Economic Reforms in Ghana: The Miracle and the Mirage, Oxford: James Currey.

Ayoob, M. (2004) 'Turkey's multiple paradoxes', Orbis, 48: 451-63.

BMZ (2005) Karl-Heinz Jonas, 2 June 2005, and 8 June 2005 per e-mail, Bonn: Bundesministerium für wirtschaftliche Zusammenarbeit und Entwicklung (BMZ).

Baker, G. and Chandler, D. (eds) (2005) Global Civil Society. Contested Futures, London and New York: Routledge.

Berman, B. J. (1998) 'Ethnicity, patronage and the African state: the politics of uncivil nationalism', African Affairs, 97: 305-41.

Blyth, M. and Katz, R. (2005) 'From catch-all politics to cartelisation: the political economy of the cartel party', West European Politics, 28 (1): 33-60.

Bogaards, M. (2004) 'Counting parties and identifying (dominant) party systems in Africa', European Journal of Political Research, 43 (2): 173-97.

Bonoli, G. and Powell, M. (eds) (2004) Social Democratic Party Policies in Contemporary Europe, London: Routledge.

Bratton, M., Chikwana, A. and Sithole, T. (2005) 'Propaganda and public opinion in Zimbabwe', Journal of Contemporary African Studies, 23 (1): 77-108.

Burnell, P. (ed.) (2000) Democracy Assistance. International Co-operation for Democratization, London: Frank Cass.

Burnell, P. (2001) 'Promoting parties and party systems in new democracies: is there anything the "international community" can do?', in K. Dowding, J. Hughes and H. Margetts (eds) Challenges to Democracy, Houndmills: Palgrave in association with Political Studies Association. 
Burnell, P. (2004) Building Better Democracies. Why Political Parties Matter, London: Westminster Foundation for Democracy.

Burnell, P. and Ware, A. (eds) (1998) Funding Democratization, Manchester: Manchester University Press.

Çarkoğlu, A. and Toprak, B. (2000) Türkiye'de Din, Toplum ve Siyaset, Istanbul: TESEV.

Carothers, T. (1996) Assessing Democracy Assistance: the Case of Romania, Washington DC: Carnegie Endowment for International Peace.

Carothers, T. (1997) 'Democracy assistance: the question of strategy', Democratization, 4 (3): 109-32.

Carothers, T. (1999) Aiding Democracy Abroad: The Learning Curve, Washington DC: Carnegie Endowment for International Peace.

Carothers, T. (2002) 'The end of the transition paradigm', Journal of Democracy, 13 (1): 5-21.

Carothers, T. (2004a) Critical Mission: Essays on Democracy Promotion, Washington DC: Carnegie Endowment for International Peace.

Carothers, T. (2004b) Political Party Aid: Issues for Reflection and Discussion, mimeo. Report prepared for Swedish International Development Cooperation Agency, Stockholm. Available online at: www.idea.int/parties/upload/Political_ Party_Aid_by_Carothers_Oct04.pdf (accessed 10 January 2006).

Carothers, T. (2006) Confronting the Weakest Link: Aiding Political Parties in New Democracies, Washington, DC: Carnegie Endowment for International Peace.

Chandhoke, N. (2005) 'Revisiting the crisis of representation thesis: the Indian context', Democratization, 12 (3): 308-30.

Chiroro, B. (2005) 'Political parties and democratic governance: South Africa and Zimbabwe', paper presented at the UNISA Africa Day Conference, UNISA, Pretoria; 2 June 2005.

Chirwa, C. W. (1994) 'The politics of ethnicity and regionalism in contemporary Malawi', African Rural and Regional Studies, 1 (2): 93-118.

Chua, A. (2003) World on Fire: How Exporting Free Market Democracy Breeds Ethnic Hatred and Instability, New York: Doubleday.

Clapham, C. (1985) Private Patronage and Public Power: Political Clientelism in the Modern State, London: Frances Pinter.

Clift, B. (2002) 'Social democracy and globalization', Government and Opposition, 37 (4): 466-500.

Cole, A. (2005) 'Old right or new right? The ideological positioning of parties of the far right', European Journal of Political Research, 44 (2): 203-30.

Collin, M. (2001) This is Serbia Calling, London: Serpent's Tail.

Commonwealth Secretariat (2005) Sri Lanka Presidential Election 17 November 2005. Report of the Commonwealth Expert Team, London: Commonwealth Secretariat.

Conversi, D. (2000) 'Central secession: towards a new analytic concept? The case of former Yugoslavia', Journal of Ethnic and Migration Studies, 16 (2): 333-56.

Cosbey, A., Tay, S., Lim, H. and Walls, M. (2005) The Rush to Regionalism, Winnipeg: International Institute for Sustainable Development.

Crook, N., Dauderstädt, D. and Gerrits, A. (eds) (2002) Social Democracy in Central and Eastern Europe, Bonn-Amsterdam: Friedrich Ebert Stiftung. 


\section{References}

Cutler, A. C., Haufler, V. and Porter, T. (eds) (1999) Private Authority and International Affairs, Albany NY: State University of New York Press.

Daği, I. (2004) 'Rethinking human rights, democracy and the West: post-Islamist intellectuals in Turkey', Critique: Critical Middle Eastern Studies, 13 (2): 135-51.

Dahl, R. (1971) Polyarchy: Participation and Opposition, New Haven CT: Yale University Press.

Daniel, J. and Southall, R. (1999) 'Electoral corruption and manipulation in Africa: the case for international monitoring', in J. Daniel, R. Southall and M. Szeftel (eds) Voting for Democracy: Watershed Elections in Contemporary Anglophone Africa, Aldershot: Ashgate, 37-56.

Daniel, J. and Lutchman, J. (2005) 'South Africa in Africa: scrambling for energy', in S. Buhlungu, J. Daniel, J. Lutchman and R. Southall, State of the Nation: South Africa 2005-06, Cape Town: HSRC Press, 484-509.

Dauderstädt, M. (2004) Conflicting Distributive Interests in a Deepening and Widening Europe: A Challenge to the Emerging Europolity, Friedrich Ebert Stiftung. Available online at: www.fes.de/europolity (accessed 31 January 2006).

Davison, A. (2003) 'Turkey, a "secular" state: the challenge of description', South Atlantic Quarterly, 102 (2/3): 333-50.

Desai, M. and Redfern, P. (eds) (1995) Global Governance: Ethics and Economics of the World Order, London: Pinter.

Diamond, L. and Gunther, R. (eds) (2001) Political Parties and Democracy, Baltimore MD and London: The Johns Hopkins University Press.

Election Commission of Kenya (1992, 1997, 2002) Parliamentary Election Result Reports for 1992, 1997 and 2002, Nairobi: Government of Kenya.

Englund, H. (ed) (2002) A Democracy of Chameleons: Politics and Culture in the New Malawi, Uppsala: Nordiska Afrikainstitut.

Erdmann, G. (1996) Demokratie und Demokratieförderung in der Dritten Welt. Ein Literaturbericht und eine Erhebung der Konzepte und Instrumente, Bonn: Deutsche Kommission Justita et Pax.

Erdmann, G. (2002) 'Zur Typologie politischer Parteien in Afrika', Afrika Spectrum, 37 (3): 259-85.

Erdmann, G. (2004) 'Party research: the Western European bias and the "African labyrinth", Democratization, 11 (3): 63-87.

Finkel, S., Pérez-Liñán, A., Seligson, M. and Azpuru, D. (2005) Effects of US Foreign Assistance on Democracy Building: Results of a Cross-National Quantitative Survey: Final Report, USAID/Vanderbilt University/University of Pittsburg. Online. Available online at: www.lapopsurveys.org/.

Fouskas, V. (2003) Zones of Conflict: US Foreign Policy in the Balkans and the Greater Middle East, London: Verso.

Fukuyama, F. (1992) The End of History and the Last Man, London: Hamish Hamilton.

Furedi, F. (2005) Beyond Left and Right: the Politics of Fear, London: Continuum. Gaffney, J. (ed.) (1996) Political Parties and the European Union, London and New York: Routledge.

Gallagher, T. (2003) The Balkans Since the Cold War: From Tyranny to Tragedy, London: Routledge.

Gallagher, T. (2004) 'Balkan but different: Romania and Bulgaria's contrasting paths to NATO membership 1994-2002', Journal of Communist and Transition Studies, 20 (3): 1-19. 
Gallagher, T. (2005a) Theft of a Nation: Romania since Communism, London: Hurst \& Co.

Gallagher, T. (2005b) The Balkans in the New Millennium: In the Shadow of War and Peace, London: Routledge.

Garrett, G. (1998) Partisan Politics in the Global Economy, Cambridge: Cambridge University Press.

German Marshall Fund of the United States (2005) Transatlantic Trends Key Findings 2005. Available online at: www.transatlantictrends.org/index.cfm? id=2 (accessed 30 January 2006).

Gerrits, A. (2002) 'The social democratic tradition in East Central Europe', East European Politics and Societies, 16 (1): 54-108.

Gershman, C. (2004) 'Democracy promotion: the relationship of political parties and civil society', Democratization, 11 (3): 27-35.

Glickman, H. (ed.) (1996) Ethnic Conflicts and Democratization in Africa, Atlanta GA: African Studies Association Press.

Good, K. (2002) The Liberal Model and Africa: Elites against Democracy, London: Palgrave.

Good, K. and Taylor, I. (2005) 'Unpacking the model: presidential succession in Botswana', in R. Southall and H. Melber (eds) Legacies of Power: Leadership Change and Former Presidents in African Politics, Cape Town: HSRC Press, 51-72.

Grzymala-Busse, A. and Innes, A. (2003) 'Great expectations: the EU and domestic political competition in East Central Europe', East European Politics and Societies, 17 (1): 64-73.

Gunther, R. and Diamond, L. (2001) 'Types and functions of parties', in L. Diamond and R. Gunther (eds) Political Parties and Democracy, Baltimore MD and London: The John Hopkins University Press, 3-39.

Halifax Initiative (2004) Who's Minding the Store? Legislator Oversight of the Bretton Woods Institutions, Ottawa: Halifax Initiative.

Hall, R. B. and Biersteker, T. J. (2003) The Emergence of Private Authority in Global Governance, Cambridge: Cambridge University Press.

Halperin, M. and Galic, M. (eds) (2005) Protecting Democracy. International Responses, Lanham MD: Lexington Books and Council of Foreign Relations.

Hanf, T., Hofmeier, R. and Mair, S. (1995) Evaluierung der Aktivitäten der politischen Stiftungen in der Republik Südafrika, Bonn: Bundesministerium für wirtschaftliche Zusammenarbeit und Entwicklung.

Harriss, J., Stokke, K. and Törnquist, O. (eds) (2005) Politicising Democracy: The New Local Politics of Democratisation, Basingstoke: Palgrave Macmillan.

Henderson, K. (2004) 'Decision-making in the new EU: the case of Slovakia', in A. Ágh (ed.) Post-Accession in East Central Europe: The Emergence of the EU25, Budapest: Hungarian Centre for Democracy Studies.

Heper, M. (1997) 'Islam and democracy in Turkey: towards a reconciliation?', The Middle East Journal, 51: 31-45.

Heper, M. and Rubin, B. (2002) Political Parties in Turkey, London: Frank Cass. Herman, V. (1976) Parliaments of the World: A Reference Compendium, Berlin and New York: De Gruyter.

Hettne, B., Inotai, A. and Sunkel, O. (eds) (1999) Globalism and the New Regionalism, Basingstoke: Macmillan. 


\section{References}

Hillebrand, E. and Vinai, V. (2002) 'The Friedrich Ebert Stiftung and German policy on Africa - some remarks', in U. Engel and R. Kappel (eds) Germany's Africa Policy Revisited: Interests, Images and Incrementalism, Münster: Lit Verlag, 127-41.

Hix, S. (1996) 'The transnational party federations', in J. Gaffney (ed.) Political Parties and the European Union, London and New York: Routledge.

Hix, S., Kreppel, A. and Noury, A. (2003) 'The party system in the European Parliament: collusive or competitive?', Journal of Common Market Studies, 1 (2): 309-32.

Horowitz, D. (1985) Ethnic Groups in Conflict, Berkeley CA: University of California Press.

Horowitz, D. and Plattner, M. (eds) (1993) The Global Resurgence of Democracy, Baltimore MD: The Johns Hopkins University Press.

Hughes, C. W., Cooper, A. and Delombaerde, P. (eds) (forthcoming) Regionalisation and the Taming of Globalisation?, London: Routledge.

Hughes, J., Sasse, G. and Gordon, G. (2004) Europeanization and Regionalization in the EU's Enlargement to Central and Eastern Europe: The Myth of Conditionality, New York: Palgrave Macmillan.

Huntington, S. (1991) The Third Wave: Democratization in the Late Twentieth Century, London and Norman OK: University of Oklahoma Press.

Ibarra, P. (ed.) (2003) Social Movements and Democracy, Houndmills: Palgrave Macmillan.

Institute for Multiparty Democracy (2004) A Framework for Democratic PartyBuilding, The Hague: Netherlands Institute for Multiparty Democracy.

International Institute for Democracy and Electoral Assistance (2003) Funding of Political Parties and Election Campaigns, Stockholm: International IDEA.

Inter-Parliamentary Union (1976) Statutes of Inter-Parliamentary Union, Geneva: Inter-Parliamentary Union.

Johnson, D. (2005) 'The new outsiders of Central and Eastern Europe, with specific reference to Poland', European Integration, 27 (1): 111-31.

Jung, D. (2005) 'Turkey and the Arab world: historical narratives and new political realities', Mediterranean Politics, 10 (1): 1-17.

Kabemba, C. (2003) From Military Rule to Multiparty Democracy: Political Reforms and Challenges in Lesotho, Auckland Park: Electoral Institute of Southern Africa.

Kabemba, C. (2004) Swaziland's Struggle with Political Liberalisation, Auckland Park: Electoral Institute of Southern Africa.

Kabemba, C. (2005) 'The contribution of donors to the consolidation of democracy in Malawi', in Nixon S. Khembo (ed.) Elections and Democratisation in Malawi: An Uncertain Process, Auckland Park: Electoral Institute of Southern Africa, 50-61.

Kadalie, R. (2005) 'Unrest, gas and insults call back unhappy past', Business Day (Johannesburg), 9 June.

Kalipeni, E. (1997) 'Regional polarisation in voting pattern: Malawi 1994 elections', African Journal of Political Science, 2 (1): 152-67.

Kaldor, M. (1998) New and Old Wars: Organized Violence in a Global Era, London: Polity Press.

Ka-Lok Chan, K. (2003) 'Political ideologies in post-communist Europe: consensus or disunity?', Central European Political Science Review, 14: 28-53. 
Kalyvas, S. N. (1996) The Rise of Christian Democracy in Europe, Ithaca NY: Cornell University Press.

Kamwendo, G. (2002) 'Ethnic revival and language associations in the new Malawi', in H. Englund (ed.) A Democracy of Chameleons: Politics and culture in the New Malawi, Uppsala: Nordiska Afrikainstitut, 140-50.

Karume, S. (2004a) 'The role of donors in Tanzania's democratisation process', in Shumbana Karume (ed.) Dilemmas of Political Transition: Towards Institutionalisation of Multiparty Democracy in Tanzania, Auckland Park: Electoral Institute of Southern Africa.

Karume, S. (2004b) 'Donors' support to democratization in Zambia', in C. Kabemba (ed.) Elections and Democracy in Zambia, Auckland Park: Electoral Institute of Southern Africa, 41-57.

Katz, R. and Mair, P. (1995) 'Changing models of party organisation and party democracy: the emergence of the cartel party', Party Politics, 1 (1): 5-28.

Katz, R. and Mair, P. (2002) 'The ascendancy of the party in public office: party organizational change in twentieth century democracies', in R. Gunther, J. Montero and J. Linz (eds) Political Parties. Old Concepts and New Challenges, Oxford: Oxford University Press, 113-35.

Keck, M. and Sikkink, K. (1998) Activists Beyond Borders: Democracy Networks in International Politics, Ithaca NY: Cornell University Press.

Keyman, F. and Içduygu, A. (2005) Citizenship in a Globalizing World: European Questions and Turkish Experiences, London: Routledge.

Kitschelt, H. (2004) Diversification and Reconfiguration of Party Systems in Postindustrial Democracies, Friedrich Ebert Stiftung, International Policy Analysis Paper, Bonn. Online. Available www.fes.de/europolity (accessed 31 January 2006).

Knaus, G. and Whyte, N. (2004) 'The Internationals and the Balkans: time for a change', Institute for War and Peace Reporting (IWPR), Balkans Crisis Report 505, 2 July 2004.

Kornhauser, W. (1959) The Politics of Mass Society, New York: The Free Press.

Kostelecky, T. (2002) Political Parties after Communism: Developments in EastCentral Europe, Baltimore, MD and London: The Johns Hopkins University Press.

Krouwel, A. (2004) 'All politics is national, but policy is supranational: a decisive discrepancy', Friedrich Ebert Stiftung, Europolity Programme. Online. Available www.fes.de/europolity (accessed 31 January 2006).

Kumar, K. (2005) 'Reflections on international political party assistance', Democratization, 12 (4): 506-28.

Kurtz, M. (2002) 'Understanding the third world welfare state after neoliberalism', Comparative Politics, 34 (3): 293-312.

Ladrech, R. (2002) 'Europeanisation and political parties: towards a framework for analysis', Party Politics, 8 (4): 389-403.

Linde, J. and Ekman, J. (2003) 'Satisfaction with democracy: a note on a frequently used indicator in comparative politics', European Journal of Political Research, 42 (3): 391-408.

McGrew, A. (2002) 'From global governance to good governance: theories and prospects of democratizing the global polity', in M. Ougaard and R. Higgott (eds) Towards a Global Polity, London and New York: Routledge. 


\section{References}

McGrew, A. (2005) 'Globalization and global politics', in J. Baylies and S. Smith (eds) The Globalization of World Politics, 3rd edition, Oxford: Oxford University Press.

Mainwaring, S. (1998) 'Party systems in the third wave', Journal of Democracy, 9 (3): $66-81$.

Mair, S. (2000a) 'Germany's Stiftungen and democracy assistance: comparative advantages, new challenges', in P. Burnell (ed.) Democracy Assistance: International Co-operation for Democratization, London: Frank Cass.

Mair, S. (2000b) 'Parlamentskooperation der Friedrich-Ebert-Stiftung in afrika. Vergleichende Studie Ghana, Namibia, Simbabwe, Südafrika', report to the Friedrich Ebert Stiftung, München. Online. Available http://fesportal.fes.de/pls/ portal30/docs/FOLDER/INTERNATIONAL/AFRIKA/studien/studien.html (accessed December 2005).

Mair, S. (2004) 'Multi-partisan or bi-partisan co-operation: what is the best solution for democracy assistance?', in A European Profile in Democracy Support, Conference reader 'Enhancing the European profile in democracy assistance', The Hague, 5-6 July.

Malawi Election Committee (1994, 1999, 2004) Parliamentary Election Result Reports, Lilongwe: Government of Malawi.

Masterson, G. (2004) Governance Quality and Government Commitment to the NEPAD African Peer Review Mechanism, Auckland Park: Electoral Institute of Southern Africa.

Masterson G. and Letsholo. S. (2005) 'The new challenges of democracy assistance in South Africa', in L. Piper (ed.) South Africa's 2004 Election: The Quest for Democratic Consolidation, Auckland Park: Electoral Institute of Southern Africa, 7-35.

Mkandawire, T. (1999) 'Crisis management and the making of "choiceless democracies", in R. Joseph (ed.) State, Conflict and Democracy, Boulder CO: Lynne Rienner.

Mohamed Salih, M. A. (1999) Environmental Politics and Liberation in Contemporary Africa, London, Kluwer Academic Publishers.

Mohamed Salih, M. A. (2001) African Democracies and African Politics, London: Pluto.

Mohamed Salih, M. A. (2003) 'Introduction', in M. A. Mohamed Salih (ed.) African Political Parties: Evolution, Institutionalisation and Governance, London, Pluto, $1-33$.

Mohamed Salih, M. A. (2005) 'The challenges of internal party democracy in Africa', in UNDP Handbook of Political Parties, New York: United Nations Development Programme.

Mosley, L. (2005) 'Globalisation and the state: still room to move?', New Political Economy, 10 (3): 355-62.

Mozaffar, S., Scaritt, J. R. and Galaich, G. (2003) 'Electoral institutions ethnopolitical cleavages, and party systems in Africa's emerging democracies', American Political Science Review, 97 (3): 379-90.

Nasr, V. (2005) 'The rise of "Muslim democracy", Journal of Democracy, 16 (2): 13-27.

National Electoral Commission of Ghana (1993, 1997, 2001, 2004). Election Results, Accra: Government of Ghana.

Norden, D. (1998) 'Party politics and democracy in Latin America', Party Politics, 4 (4): 423-43. 
Olaleye, W. (ed.) (2005) Negotiating the Impasse: Challenges and Prospects for Democratisation in Zimbabwe, Johannesburg: Electoral Institute of Southern Africa.

Öniş, Z. (2001) 'Political Islam at the crossroads: from hegemony to co-existence', Contemporary Politics, 7 (4): 281-98.

Öniş, Z. (1997) 'The political economy of Islamic resurgence in Turkey: the rise of the Welfare Party in perspective', Third World Quarterly, 18 (4): 743-66.

Öniş, Z. and Keyman, F. (2003) 'A new path emerges', Journal of Democracy, 14 (2): 95-108.

Öniş, Z. and Rubin, B. (2003) The Turkish Economy in Crisis, London: Frank Cass.

Ottaway, M. and Chung, T. (1999) 'Toward a new paradigm', Journal of Democracy, 10 (4): 104-6.

Ottaway, M. and Carothers, T. (eds) (2000) Funding virtue, Civil Society Aid and Democracy Promotion, Washington, DC: Carnegie Endowment for International Peace.

Patomäki, K. S. and Ulvila, M. (eds) (2006) 'Democratic politics globally: elements for a dialogue on global party formations', Helsinki: Network Institute for Global Democratization, draft working paper.

Pempel, T. J. (1990) Uncommon Democracies: The One-party Dominant Regimes, Ithaca NY: Cornell University Press.

Piano, A. and Puddington, A. (2006) 'The 2005 Freedom House survey', Journal of Democracy, 17 (1): 119-24.

Piazza, J. (2001) 'De-linking labor: labor unions and social democratic parties under globalization', Party Politics, 7 (4): 413-35.

Pinto-Duschinsky, M. (1991) 'Foreign political aid: the German political foundations and their US counterparts', International Affairs, 67 (1): 33-63.

Pinto-Duschinsky, M. (1996) 'International political finance: the Konrad Adenauer Foundation and Latin America', in L. Whitehead (ed.) International Dimensions of Democratization, Oxford: Oxford University Press.

Poguntke, T. and Webb, P. (eds) (2005) The Presidentialization of Politics: A Comparative Study of Modern Democracies, Oxford: Oxford University Press.

Posner, D. N. (2004) Institutions and Ethnic Politics in Africa, Cambridge: Cambridge University Press.

Power Commission (2006) Power to the People. An Independent Inquiry into Britain's Democracy, York: Joseph Rowntree Foundation.

Pridham, G. (1999a) 'The European Union, democratic conditionality and transnational party linkages: the case of Eastern Europe', in J. Grugel (ed.) Democracy Without Borders, London: Routledge.

Pridham, G. (1999b) 'Complying with the European Union's democratic conditionality: transnational party linkages and regime change in Slovakia, 19931998', Europe-Asia Studies, 51 (7): 1221-44.

Pridham, G. (2005) Designing Democracy: EU Enlargement and Regime Change in Post-Communist Europe, New York: Palgrave Macmillan.

Pridham, G. and Ágh, A. (eds) (2001) Democratic Transition and Consolidation in East-Central Europe, Manchester: Manchester University Press.

Puddington, A. and Piano, A. (2005) 'The 2004 Freedom House survey', Journal of Democracy, 16 (1): 103-8.

Pugh, M. (2004) 'Rubbing salt into war wounds: shadow economies and peacebuilding in Bosnia and Kososvo', Problems of Post-Communism, 51 (3): 53-60. 


\section{References}

Putnam, R. (2000) Bowling Alone: The Collapse and Revival of American Community, New York: Simon \& Schuster.

Quigley, K. (2000) 'Lofty goals, modest results: assisting civil society in Eastern Europe', in M. Ottaway and T. Carothers (eds) Funding Virtue. Civil Society Aid and Democracy Promotion, Washington DC: Carnegie Endowment for International Peace, 191-215.

Randall, V. and Svåsand, L. (2002a) 'Party institutionalisation in new democracies', Party Politics, 8 (1): 5-29.

Randall, V. and Svåsand, L. (2002b) 'Political parties and democratic consolidation in Africa', Democratization, 9 (3): 30-52.

Raunia, T. (2002) 'Why European integration increases leadership autonomy within political parties', Party Politics, 8 (4): 405-22.

Reilly, B. (2003) 'Political engineering of parties and party systems', paper presented at the 2003 Annual Meeting of the American Political Science Association, posted on the website of the Centre for Democratic Institutions, of the Australian National University. Online. Available www.cdi.anu.edu.au (accessed 31 January 2006).

Riethof, M. (2004) 'Changing strategies of the Brazilian labor movement: from opposition to participation', Latin American Perspectives, 31 (6): 31-47.

Riggirozzi, M. P. (2005) 'The World Bank as a norm-broker: knowledge, funds and power in governance reforms in Argentina', unpublished doctoral thesis, University of Warwick.

Rimanelli, M. (ed.) (1999) Comparative Democratization and Peaceful Change in Single-Party-Dominant Countries, New York: St. Martin's Press.

River Path Associates (2005) Review of the Westminster Foundation for Democracy (3 volumes). Online. Available www.fco.gov.uk (accessed 30 January 2006).

Robinson, W. (1996) Promoting Polyarchy: Globalization, US Intervention, and Hegemony, Cambridge: Cambridge University Press.

Schmitter, P. (2001) 'Parties are not what they once were', in L. Diamond and R. Gunther (eds) Political Parties and Democracy, London: The Johns Hopkins University Press, 67-89.

Scholte, J. A. (2002) 'Civil society and governance in the global polity', in M. Ougaard and R. Higgott (eds) Towards a Global Polity, London: Routledge.

Scholte, J. A. (2004) 'Civil society and democratically accountable global governance', Government and Opposition, 39 (2): 211-33.

Scholte, J. A. (2005) Globalization: a Critical Introduction, second edition, Basingstoke and New York: Palgrave Macmillan.

Schumpeter, J. (1942) Capitalism, Socialism and Democracy, New York: Harper \& Row.

Scott, J. (1999) 'Transnationalizing democracy promotion: the role of western political foundations and think-tanks', Democratization, 6 (3): 146-70.

Scott, J. M. and Walters, K. J. (2000) 'Supporting the wave: western political foundations and the promotion of a global democratic society', Global Society, 14 (2): 237-57.

Sebudubudu D and Osei-Hwedie, B. (2005) Democratic Consolidation in SADC: Botswana's 2004 Elections, Auckland Park: Electoral Institute of Southern Africa.

Sellstrom. T. (2002) Sweden and National Liberation in Southern Africa: Volume II: Solidarity and Assistance 1970-1994, Uppsala: Nordiska Africainstitut.

Sikk, A. (2005) 'How unstable? Volatility and the genuinely new parties in Eastern Europe', European Journal of Political Research, 44 (3): 391-412. 
Sithole, N. (1959) African Nationalism, New York: Oxford University Press.

Slaughter, A.-M. (2004) A New World Order, Princeton NJ: Princeton University Press.

Slomczynski, K. and Shabad, G. (2003) 'Dynamics of support for European integration in post-communist Poland', European Journal of Political Research, 42 (4): 503-40.

Southall R. (1995) Solidarity or Imperialism? International Labour and South African Trade Unions, Cape Town: University of Cape Town Press.

Southall, R. (2001) 'Conclusion: emergent perspectives on opposition in South Africa', Democratization, 8 (1): 275-84.

Southall, R. (2003a) 'Democracy in southern Africa: moving beyond a difficult legacy', Review of African Political Economy, 96 (30): 255-72.

Southall, R. (2003b) 'An unlikely success: South Africa's and Lesotho's election of 2002', The Journal of Modern African Studies, 41 (2): 269-96.

Southall R. (2005) 'South Africa: a developmental state of a special kind?', in S. Buhlungu, J. Daniel, J. Lutchman and R. Southall, State of the Nation: South Africa 2005-06, Cape Town: HSRC Press, xvii-xlv.

Stan, L. (2005) 'The opposition takes charge: the Romanian general election of 2004', Problems of Post-Communism, 52 (3): 3-15.

Taggart, P. and Szczerbiak, A. (2001) 'Parties, positions and Europe: Euroscepticism in the EU candidate states of Central and Eastern Europe', Sussex European Institute Working Paper No. 46. Online. Available www.sussex.ac.uk/sei (accessed 31 January 2006).

Tangri, R. (1999) The Politics of Patronage in Africa: Parastatals, Privatization and Private Enterprise, Oxford: James Currey.

Taniyici, S. (2003) 'Transformation of political Islam in Turkey: the Islamist Welfare Party's pro-EU turn', Party Politics, 9 (4): 463-83.

Toprak, B. (2005) 'Islam and democracy in Turkey', Turkish Studies, 6 (2): 167-86. Vachudova, M. (2005) Europe Undivided, Oxford: Oxford University Press.

Van Biezen, I. (2003) Political Parties in New Democracies: Party Organisation in Southern and East-Central Europe, London: Palgrave.

Van Biezen, I. (2004) 'Political parties as public utilities', Party Politics, 10 (6): 701-22.

Van Biezen, I. (2005) 'On the theory and practice of party formation and adaptation in new democracies', European Journal of Political Research, 44 (1): 147-74.

Van Cranenburgh, O. (1999) 'International policies to promote African democratization', in J. Grugel (ed.) Democracy Without Borders, London: Routledge.

Van de Walle, N. (2003) 'Presidentialism and clientelism in Africa's emerging party system', Journal of Modern African Studies, 41 (2): 297-321.

Van Wersch, J. and de. Zeeuw, J. (2005) Mapping European Democracy Assistance: Tracing the Activities and Financial Flows of Political Foundations, The Hague: Netherlands Institute of International Relations ('Clingendael'), Conflict Research Unit Working Paper No. 36.

Von Beyme, K. (2000) Parteien im Wandel, Wiesbaden: Westdeutscher Verlag.

Von Beyme, K. (2001) 'Parties in the process of consolidation in East-Central Europe', in G. Pridham and A. Ágh (eds) Democratic Transition and Consolidation in East-Central Europe, Manchester: Manchester University Press.

Webb, P. (2005) 'Political parties and democracy: the ambiguous crisis', Democratization, 12 (5): 633-50. 


\section{References}

Webb, P., Farrell, D. and Holliday, I. (eds) (2002) Political Parties in Advanced Industrial Democracies, Oxford: Oxford University Press.

Weiss, L. (1998) The Myth of the Powerless State: Governing the Economy in a Global Era, Cambridge: Polity and Ithaca, NY: Cornell University Press.

Weiss, L. (2005) 'The state-augmenting effects of globalisation', New Political Economy, 10 (3): 345-53.

Westminster Foundation for Democracy (2005) Working for a Freer World: WFD's Response to the River Path Associates Report, London: Westminster Foundation for Democracy. Online. Available www.fco.gov.uk (accessed 31 January 2006).

Wheeler, N. and Bellamy, A. (2005) 'Humanitarian intervention in world politics', in J. Baylis and S. Smith (eds) The Globalization of World Politics, Oxford: Oxford University Press, 555-78.

Whitehead, L. (ed.) (1999) International Dimensions of Democratization, Oxford: Oxford University Press.

Winter, L. de and Chachafeiro, M. (2002) 'European integration and ethnoregionalist parties', Party Politics, 8 (4): 483-503.

Yavuz, H. (2003) Islamic Political Identity in Turkey, New York: Oxford University Press.

Yilmaz, H. (2002) 'External-internal linkages in democratization: developing an open model of democratic change', Democratization, 9 (2): 67-84.

Zeeuw, J. de and Kumar, K. (eds) (2006) Promoting Democracy in Postconflict Societies: A Comparative Perspective, Boulder CO: Lynne Rienner. 


\section{Index}

Page references in italic indicate tables.

Ágh, A. 13, 33, 202

Africa, sub-Saharan 10, 11; African

Peer Review Mechanism 176, 203;

attitudes to democracy 175 ; civil society $171-3$; civil society aid 171-3, 196; clientelism 2, 158-9; colonial legacy 11, 141, 142, 158; conflict resolution 170-1;

democracy assistance to 163 , 166-74, 176-80; economic performance 175-6; electoral assistance to 168-70; elitism 164; ethnic politics 142, 155, 156, 157, 158, 160, 186; and globalisation 11, 12, 143, 155, 200; intra-party democracy 159-60, 192; national liberation movements 164, 165; 'new scramble' 163, 165, 176; parliamentary assistance 171 ; parliamentary networks 144, 152; parliaments 171 ; party aid to 11 , 13n1, 69, 173-4, 177-80, 187-8; party networks $144,151,153-4$, 160; political parties $3 \mathrm{n} 1,28$, 141-62, 184-6, 192, 199, 203; quasi-polyarchy in 11, 144; southern Africa 163-80; see also individual countries; individual parties

African Christian Democrats Union (ACDU) 153

African National Congress (South Africa) 173, 174, 175, 178, 193, 203

Albania 106, 107

Algeria 35

Al Qaeda 34
Argentina 42

Association of Southeast Asian Nations (ASEAN+3) 49

Baker, G. 33

Balkans 26; and EU 26, 112-13, 118, 119; international influences on 104-5, 110-11, 121; nongovernmental organisations 116-18; post-communist decline 167; US views of 106, 108; and Western parties 117-18, 202; see also individual countries

Banda, President Hastings 148

Belarus 80

Blyth, M. 27, 35

Bosnia-Herzegovina 10, 21, 107-8, 109,119 ; privatisation in 109-10, 120

Botswana 169, 170, 174, 175, 186, 189, 190

Brazil 45n10, 50

Bretton Woods institutions 11, 31, 41; see also International Monetary Fund; World Bank

Britain 35, 41; Department for International Development (DFID) 170; see also Power Commission report; Westminster Foundation for Democracy

Bulgaria 107, 111, 117; democracy aid to 106,111

Bundesministerium für wirtschaftliche Zusammenarbeit und Entwicklung (BMZ, Ministry for Economic Co-operation and Development, Germany) 182, 183, 189 


\section{Index}

Burnell, P. 14n3, 14n5, 24, 184, 193, 194, 195

Canada 50

Carnegie Endowment for International Peace 7

Carothers, T. 6, 14n7, 20, 165, 188, 204, 206

Carter Center 166

Central American Parliament 64, 65

Centre for Democratic Institutions (Australia) 6

Centre for the Study of Globalisation and Regionalisation (CSGR) ix, $15 \mathrm{n} 2$

Chama Cha Mapinduzi (Tanzania) 169, 170-1

Chandhoke, N. 45n9

Chandler, D. 33

Chile 15n10, 37

China 174, 179, 202

Christian Democratic Union (Germany) 182

Christian Social Union (Germany) 182

Chua, A. 40, 119

Chung, T. 36

civic education $18,24,31,45 \mathrm{n} 8,78$, 188-9

civil society $8,52,59,182$; civic associations 18, 19, 25; and democratisation 8; global 53, 67; relations with political parties 25 , 34, 37-8, 55, 61, 76-8, 116-18, 160, 204; transnational 32-4, 37, 61; uncivil 34-5, 38; see also non-governmental organisations clientelism 2, 28, 41, 158-9, 186, 200 Clift, B. $14 \mathrm{n} 8$

Commonwealth Parliamentary Association 63, 152, 161, 167; Pan-African Commonwealth Parliamentary Group 152

Community of Democracies 6

Croatia 106, 107, 111, 118

Czech Republic 10, 94, 95, 100, $103 n 6$

Dahl, R. 144, 145

democracy 51; democratic consolidation $44 \mathrm{n} 2$; democratic deficits 52-3, 54; democratisation 3, 4, 19, 25-6; polyarchy 144,145 ; quasi-polyarchy $11,144,160$ democracy assistance 4-5, 6, 8, 13, 69, 120, 202-8; assessment 75, 197, 198, 209; civil society support 8 , 33 ; in difficult environments 21 ; Western support for 5, 13n2, 35; see also international party support

Democratic Opposition of Serbia (DOS) 115

Democratic Party (Romania) 117

Democrat Union of Africa/African Dialogue Group 153

Department for International Development see Britain

Diamond, L. 4, 45n7, 186, 200

diasporas 53; see also remittances

Djindjić, Prime Minister Zorin 115, 116

East-Central Europe (ECE) 2, 10, 11, 19, 88-103, 201; attitudes to EU 93, 94, 96, 97, 98, 99, 101, 102; civil society 99; and democratisation theory 89, 96-7; Eurobarometer 100; and Europeanisation 2, 12, 13, 15n13, 88-93, 97, 101, 102, 103; and globalisation 12; international party support to $11,69,92-3,102$, 202; party cartels in 97,101 ; party cleavages in 93, 98, 102; party exhaustion 98; political deficits in 96, 97, 98, 99; political demobilization 94, 95, 96, 99; see also individual countries

Eckman, J. 100

elections 8; support to $22,84,106$, 114, 168-70; electoral systems 23 ; management 8,23

Erdmann, G. 186, 189, 205

Erdoğan, Prime Minister Recep Tayyip (Turkey) 125

European Court of Human Rights 129

European Free Alliance (EFA) 65

Europeanisation 2, 12, 15n3, 88-93, 97, 100, 122

European Parliament 45n13, 63, 64, 91, 101, 208; and ECE parties 91-2; electoral turnout 67, 103n6; party groups 118, 208

European People's Party 65, 118, 132

European Union 45n6, 167, 168; Lisbon Strategy 91, 103n2; southern enlargement 92; see also Balkans; 
East-Central Europe;

Europeanisation; European

Parliament

Every Ghanaian Living Everywhere (EGLE) 61, 147

FIDESZ (Hungary) 94, 98, 103n5

France 69, 128, 129

Free Democratic Party (Germany) 182

Freedom House (US) 10, 11

FRELIMO (Mozambique Liberation Front) 81-2, 188, 193

Friedrich Ebert Stiftung 92, 176, 182, 183, 188, 189, 190, 191, 193, 196, 197, 198

Friedrich Naumann Stiftung 182, 183, 190, 191, 193, 195, 198

Galic, M. 6

Gallagher, T. 26, 201

Garrett, G. 14n8

German Marshall Fund of the United States $13 \mathrm{n} 2$

Germany see BMZ; Stiftungen; individual political foundations

Gershman, C. 25, 116

Ghana 10, 144, 152, 153, 190; ethnic voting $156,157,185$; parliamentary representation 146, 147

global governance see governance

Global Green Federation 154

globalisation, 1, 10; anti-globalisation 32, 38, 42; defined 1, 3, 48; democratic deficits in 52-4; and democratisation 3-4, 5-6, 9, 34, 35, $36-43,54,60,62,64,67-8,208-9$; and development 38-40; and environmental politics $39,56,58$; global communications 1, 35, 43; global finance 43 ; impact on party politics 26-44; and nationalism 42-3; of party politics 1,8 ; and the poor 30-1, 39; and public policy 14n8, 27, 30, 40, 44, 50, 83, 146, 148,151 ; and the state $14 \mathrm{n} 8,27-8$, 43, 50, 57-8; 'winners' 12

Global Legislators Organisation for a Balanced Environment (GLOBE) 63

Good, K. 164, 178

governance $29,41,46,48,49,51$; and democratic deficits 28, 52-4; global 28; 'good governance' 5; polycentrism $1,32,49,51,54$
Gross, S. 89

Group of 8 (G8) 49

Gunther, R. 4, 45n7, 186, 200

Halperin, M. 6

Hamas 23

Hans Seidel Stiftung 182, 183, 191

Harland, D. 109

Heinrich Böll Stiftung 182, 183, 190

human rights 4, 58; advocacy networks $15 \mathrm{n} 10,32$; 'boomerang effect' 36

Hungarian Civic Union, see FIDESZ

Hungarian Socialist Party 103n5

Hungary 7, 10, 94, 95, 100, 103n6

Huntington, S. 104, 133

Ibarra, P. 32

India $45 \mathrm{n} 9$

indigenous peoples 53, 67

Institute for Multiparty Democracy (IMD) 7, 14n6, 75, 76, 186, 194

International Confederation of Free Trade Unions 40

International Democrat Union 153, $161 \mathrm{n} 8$

international development co-operation $5,24,29,33,41,60$

International Institute for Democracy and Electoral Assistance (IDEA) 7, 24, 75, 205

International Monetary Fund (IMF) 29, 57, 59, 60, 66, 88, 116, 143, 146,148

international party support 5,13 , 22-3, 69, 87, 120, 200-8, 209; alternatives to 21,26 ; cross-party 193; and election campaigning 22 , 84, 85; expansion 7-8, 69-70, 85; and globalisation 1, 3, 9; goals of 71,86 ; impact $81-5,209 \mathrm{n} 1$; interparty relationships 25 ; multipartisan 193, 194; and 'mythic model' 71-2; new approaches 75-8, 86-7; partisanship 78-81, 86; post-conflict 23; research on $9,15 \mathrm{n} 9,9,181$, $205-8$; resistance to $21,28,80,82$, 86; 'solidarity assistance' 178-9, 207; spending on 7; standard approach $71-5,82,84,86$; transnational party co-operation 9 , $15 \mathrm{n} 9,25,39,73$; and women 22, $25,82,85$; see also individual agencies; political parties; Stiftungen 


\section{Index}

International Republican Institute (IRI) $6,8,71,79,80,106,111,114$

Internet Corporation for Assigned Names and Numbers (ICANN) 49, 59,66

Inter-Parliamentary Union 151-2

Justice and Development Party (AKP, Turkey) 122, 125, 126, 127, 128, 129, 135, 136, 200; and EU 123, 132, 133; and globalisation 122-3; Islamist background 125,127 ; in 2002 elections 130, 131

Kabemba, C. $168,169,173$

Karume, S. 167, 172

Katz, R. 9, 27, 28, 35, 203

Kenya 10, 100, 144, 148, 152, 153, 161n3; ethnic voting 156, 157; parliamentary representation 149 ; 2002 elections 148

Kenya African National Union (KANU) 148, 149, 157

Kitschelt, H. 27, 44n4

Klaus, Prime Minister Vaclav 94

Konrad Adenauer Stiftung 93, 182, 183, 190, 191, 193, 195, 198

Kosovo 107, 110-11

Kumar, K. 9, 14n7, 22, 23, 25, 36, 96

Kurdish Workers Party (Turkey) 136

Kurtz, M. 14n8, 30

Latin America 10, 70, 81, 105; international party aid to 70,81 ; see also individual countries

Lesotho 168, 169, 170, 174, 190

Liberal International 37, 63, 154

Linde, J. 100

McGrew, A. 3, 209n3

Mainwaring, S. 16, 44n1, 45n7

Mair, P. 9, 28, 35, 203

Mair, S. 181, 187, 189, 197

Malawi 144, 148, 152, 153, 165, 167-8, 169; ethnic voting 156, 157; parliamentary representation 150

Malawi Congress Party (MCP) 148, $150,153,156$

Malaysia 124-5

MERCOSUR 64

migrants see diasporas; remittances

Milošević, President Slobodan 106, 107

Mkandawire, T. 29, 30
Mohamed Salih, M. A. 11, 142, 155, 159, 202

Mosley, L. 30

Movement for Democratic Change (Zimbabwe) 173, 177, 193

Movement for Multi-party Democracy (Zambia) 167

Mozambique 23, 81, 190

Mugabe, President Robert 170

Namibia 10, 164, 175, 190

National Democratic Congress (Ghana) 146, 147, 154, 156, 157

National Democratic Institute (NDI) 6, 8, 45n11, 71, 76, 79, 80, 106

National Endowment for Democracy (NED) 6, 7, 14n6, 105

Nationalist Action Party (MHP, Turkey) 136

National Rainbow Coalition (Kenya) 148, 149, 157

Netherlands 69 see also Institute for Multiparty Democracy

New Patriotic Party (Ghana) 146, 147, 153, 156, 157

non-governmental organisations (NGOs) 32, 33, 34, 37, 77; international non-governmental organisations (INGOs) 32, 34, 37; see also civil society

Norden, D. 19

North Atlantic Treaty Organisation (NATO) 109

Norwegian Centre for Democracy 70

Nujoma, President Sam (Namibia) 175

Olof Palme International Centre 7

Öniş, Z. 126, 200

Open Society Foundation 104

Orbán, Premier Viktor 89, 94

Organisation for Economic Cooperation and Development (OECD) 49, 66

Organisation for Security and Co-operation in Europe (OSCE) 6, 70, 110, 111

Otpor (Serbia) 117

Ottaway, M. 36

Parliamentarians for Global Action (PGA) 63

parliamentary networks 63, 151-2, 160, 161n6; see also Commonwealth 
Parliamentary Association;

Parliamentary Network on the

World Bank

Parliamentary Network on the World Bank (PNoWB) 63

party aid see international party support

Party of Democratic Socialism (PDS, Germany) 182-3, 191, 199n3

Party of European Socialists (PES) 65

party internationals see political parties; individual internationals

patron-client relations see clientelism

Peru 78

Pinto-Duschinsky, M. 37

Poguntke, T. 9, 29, 203

Poland 94, 95, 98, 100, 103n6

political funding see political parties

Political Islam 13, 123, 129, 137; see also Turkey

political parties: and civil society 25 , 34, 37-8, 55, 61, 76-8, 116-18, 160, 204; and democratisation 4, 5, 16, 17; and diasporas 61; funding of 7, 24, 43, 76, 159, 173-4, 204-5; and globalisation $2-3,5,9,14 \mathrm{n} 8$, 19-20, 26-44, 46-68; global parties 66-7; international networks 7 , 62-4; models of 71-2, 184, 200; party elites $21,28,30,35,82,91$, 155, 164, 203; party internationals 37, 62-3, 203; and personalism 30, $45 \mathrm{n} 7,184$; and 'presidentialisation' 29 ; in post-conflict situations 5 , 18-19, 20, 25; regional parties $64-5,67,68$; roles 55-62, 184; surrounding influences 5,22 , 23-44, 83; and trade unions 40, 45n10, 55, 77; transnational parties 66-7, 68, 202; and uncivil society $34-5$; in the West 2,18 , 32, 33, 35, 71, 113-14, 184, 202; see also individual parties; international party support; political party system

political party system $16,17,44 n 1$, 200; and 'choiceless democracy' 14n8, 27, 29-31, 40, 44, 50, 83, $146,148,151$; and social cleavages 24, 39

polyarchy see democracy

polycentrism see governance

Portugal 92, 98

poverty reduction strategies $31,42,78$
Power Commission report 44n5, 114, 208

Pridham, G. 9, 15n9, 37, 90

Putnam, R. 32

Randall, V. 13n1, 16, 40, 186

regional assemblies 64, 65-6

regionalisation 2, 12, 51, 64, 103; see also Europeanisation

Reilly, B. 20

remittances 45n14, 118

Republican People's Party (CHP, Turkey) 125, 131, 132

Republika Srpska 108, 109

Robinson, W. 9, 161n2

Romania 10, 59, 107, 111, 112, 116; Coalition for a Clean Parliament 117; and democracy aid 81, 106, 111; EU influence on 112-13, 119-20; non-governmental organisations 117

Rosa Luxemburg Stiftung 182, 191

Russia 80, 81, 205

Schmitter, P. 9

Scholte, J.A. 9, 32, 33, 34, 209

Schumpeter, J. 30

Scott, J. 166

Senegal 189

Serbia 10, 20, 115, 117, 118; democracy aid for 115 ; international pressure on 115-6; 2000 elections 115

Sinn Féin (Ireland) 23

Slovakia 10, 37, 98, 100, 103n6

social capital 32, 96

Social Democratic Party (SPD, Germany) 182

Social Democratic Party (PSD, Romania) 113, 117, 119

Social Democratic Party (Sweden) 79

Socialist International 63, 64, 118, 132, 146

social movements $18,19,32,34,37$, 61

South Africa 10, 12, 164, 165, 167, 172, 175, 176, 178, 179, 189, 190, 203; elections 168-169

Southall, R. 165, 167, 170, 200, 207

southern Africa see Africa, sub-Saharan

South West African People's Organisation (Namibia) 167, 174, 178, 188, 193 


\section{Index}

Sri Lanka 43

Stiftungen 6, 7, 11, 37, 70, 73, 81, $166,176,181-99$; constraints on 182; country representation 189-90, 195-6; income 182, 183; and partisanship 181-2, 193, 194-5, 196, 197, 198; party aid from 188-9, 190, 191-2; spending by 8, 191-2, 197, 198; weaknesses 197-8; see also individual Stiftungen

Svåsand, L. 13n1, 16, 40, 186

Sweden 69; party aid 70, 79

Swedish International Development Co-operation Agency 70

Taiwan 12, 174

Tanzania 167, 169, 170-1, 189-90

transnational civil society see civil society

Transparency International 41

Turkey 10, 13, 42; democratisation in 122-5; economic prospects $135-6$; and EU 12, 42, 125, 128, 132-4, 135, 137, 138; and globalisation 12, 15n12, 122-3; Higher Education Bill 140n12; Independent Industrialists and Businessmen Association (MÜSİAD) 128; Kemalist legacy 124, 137; Kurdish issues 136; and Middle East 122, 123, 125, 126, 133, 138-9; military intervention 126, 138; and Political Islam 123, 124, 126, 133-4, 137-8; financial crisis (2000-1) 123, 130; see also Justice and Development Party, Virtue Party, Welfare Party

Uganda 19, 190

United Cities and Local Governments 50-1

United Democratic Front (Malawi) 50, 154, 156

United Nations 49, 66, 161n4

United Nations Development Programme (UNDP) 6, 41, 45n11, 70,170
United States 11, 35, 41, 71, 78, 104, $105,108,112,115$; see also National Democratic Institute; National Endowment for Democracy; International Republican Institute; United States Agency for International Development

United States Agency for International Development (USAID) 6, 7, 36, 105, 109, 168, 194, 209n1

Vachudova, M. 11

Van Biezen, I. 14n4, 19

Van Cranenburgh, O. 13n1

Van Wersch, J. 7, 11

Venezuela 80

Virtue Party (FP, Turkey) 125, 126, $127,128,129$

Ware, A. 24

Washington consensus 5; postWashington consensus 31

Webb, P. 9, 29, 35, 203

Weiss, L. 28, 50

Welfare Party (RP, Turkey) 124, 125, 126, 127, 128, 129

Westminster Foundation for Democracy (WFD) 6, 7, 13n3, 14n6, 21, 110, 111

World Bank 29, 41, 42, 50, 59, 88, 143, 146, 148

World Bank Institute 41, 205

World Social Forum 61

World Trade Organization (WTO) 29, 49, 59

Yugoslavia 30, 104, 106; Dayton Peace Agreement (1995) 108, 109, 119, 120; see also Balkans; Serbia

Zambia 165, 167, 169, 190

Zeeuw, J. de 7, 11, 23

Zimbabwe 11, 80, 168, 170, 171, 172, 173, 175, 176, 177, 190, 204

Zimbabwe African National Union (ZANU) 166, 172, 173, 174, 175, 177, 188 
eBooks - at www.eBookstore.tandf.co.uk

\section{A library at your fingertips!}

eBooks are electronic versions of printed books. You can store them on your PC/laptop or browse them online.

They have advantages for anyone needing rapid access to a wide variety of published, copyright information.

eBooks can help your research by enabling you to bookmark chapters, annotate text and use instant searches to find specific words or phrases. Several eBook files would fit on even a small laptop or PDA.

NEW: Save money by eSubscribing: cheap, online access to any eBook for as long as you need it.

\section{Annual subscription packages}

We now offer special low-cost bulk subscriptions to packages of eBooks in certain subject areas. These are available to libraries or to individuals.

For more information please contact webmaster.ebooks@tandf.co.uk

We're continually developing the eBook concept, so keep up to date by visiting the website. 
